\title{
ÁGUAS SUBTERRÂNEAS NO CURSO INFERIOR DA BACIA DO RIO DOCE/RN - SUBSÍDIOS PARA UM GERENCIAMENTO INTEGRADO
}

\author{
VERA LÚCIA LOPES DE CASTRO
}

Orientador: Prof. Dr. Alberto Pacheco

TESE DE DOUTORAMENTO

COMISSÃO JULGADORA

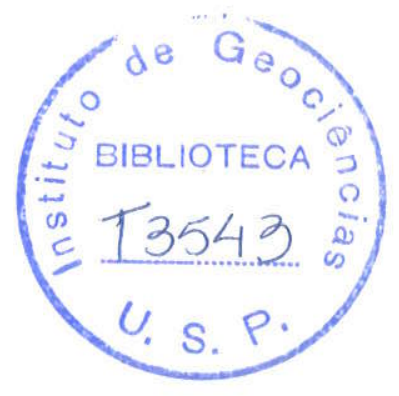

Nome

Presidente: Prof. Dr. Alberto Pacheco

Examinadores: Prof. Dr. Antonio Eduardo Leão Lanna

Prof. Dr. Ricardo César Aoki Hirata

Prof $^{\text {a. }} \cdot \mathrm{Dr}^{\mathrm{a} \cdot}$ Selma Simões de Castro

Prof $^{\text {a. }} \cdot \mathrm{Dr}^{\mathrm{a} \cdot}$ Sueli Yoshinaga Pereira
Assinatura

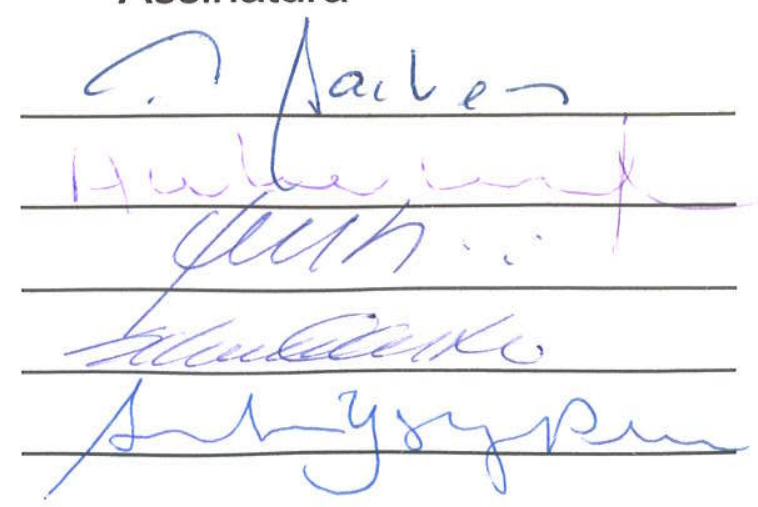

$$
\begin{aligned}
& \text { SÃO PAULO } \\
& 2000
\end{aligned}
$$

DEDALUS - Acervo - IGC

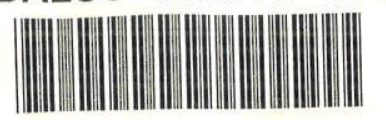


"Nenhuma noção nos é mais familiar que a da Energia Espiritual.

E nenhuma, entretanto, continua sendo para nós cientificamente mais obscura".

(O Fenômeno Humano, Pierre Teilhard de Chardin)

Aos meus pais, Anacleto e Francisca Ao meu esposo, José Agripino e nossas filhas Larissa e Camila 


\section{AGRADECIMENTOS}

Aos geólogos Paulo Varella e Carlos Martins pelo apoio no desenvolvimento da proposta da pesquisa e incentivo que deram, principalmente quando se dedicaram no sentido de conseguir algum aporte financeiro, como também da compreensão, quando precisei me ausentar das atividades profissionais para cursar o doutorado.

O apoio da Secretaria de Recursos Hídricos, através do ex Secretário Dr. Rômulo Macedo e do ex Coordenador de Infra-Estrutura Hídrica Júnior Zeferino, que reconheceu a importância da realização deste trabalho e que dentro das suas possibilidades deram apoio para a execução de algumas atividades como o cadastro dos poços tubulares, dos usuários e a realização das análises físicas e químicas.

Em especial ao meu orientador Prof. Dr. Alberto Pacheco, que acompanhou todos os momentos da pesquisa, revisando e comentando todas as partes do manuscrito e passando a sua segurança e paz de espírito nos momentos certos;

Ao Prof. Dr. Uriel Duarte, pela força que sempre me deu, pelas valiosas críticas e sugestões durante o seminário de qualificação;

Ao CNPQ pela bolsa de doutorado, durante o curso;

Gentilmente ao Serviço Autônomo de Águas e Esgotos (SAAE), escritório de Extremoz, através de Eclésia e Josafá, quando colocou à disposição todas as informações de demandas de água e as fichas técnicas dos poços tubulares por eles administrados;

Á Fundação Nacional de Saúde, (FNS), através da Dra. Ana Maria, pela cedência dos dados relacionados à incidência de esquistossomose na bacia do rio Doce.

À Companhia de Águas e Esgotos do Rio Grande do Norte, (CAERN), através dos engenheiros Marco Antonio Calazans, Jozildo e dos geólogos Marcelo Queiroz e João Maria, pelas informações sobre o consumo e qualidade das águas dos mananciais de superficie e subterrâneo;

Ao Instituto de Desenvolvimento e Meio Ambiente (IDEMA), através do seu presidente, Dr. Geraldo Magela, engenheiros José Carlos, e Ana Marcelino, quando colocaram à disposição os relatórios técnicos e as imagens de satélite para a atualização do mapa de uso e ocupação do Solo;

Ao Laboratório de Água e Solo - DATANORTE, através dos engenheiros químicos Edna, Lígia, Fátima, Dutra, Conceição, Alfredo e Isinha no sentido de orientar a coleta das amostras, realizar as análises físicas e químicas, calibrar os equipamentos utilizados em campo e permitir a consulta ao acervo deste respeitado e conceituado laboratório; 
À Empresa de Pesquisas Agropecuárias do Rio Grande do Norte (EMPARN), através de Joana Darc, Leandson e Nelson que colocaram todos os dados meteorológicos à disposição;

Às indústrias Vicunha, Guararapes Têxtil, Parmalat, Henfibra, Antártica, Coats, Laborsil, e Mastex, pelas informações prestadas e permissão ao acesso aos poços tubulares para coleta de água e medições dos níveis de água.

À empresa de perfuração de poços PROPOÇO, através do seu proprietário, Sr. Marcos Silva, que colocou a disposição o acervo das fichas técnicas dos poços tubulares;

Àqueles que me deram assistência durante a minha estada na cidade de São Paulo: Gilton, Linda, Mônica, Marcelo, Crys, Bolivar, Almany e Ana Cláudia.

Aos colegas: Bolivar, José Bráz, Jamile, Ana Lúcia, Marta, Murilo, Sônia, Anísia, Mauro e as funcionárias Ana Paula e Magaly pelo proveitoso convívio e apoio durante o período que estive na USP.

Ao amigo Elmo Marinho por todos os comentários no desenvolvimento da metodologia de pesquisa, pelas valiosas discussões e pela especial contribuição, quando fez as fotografias aéreas;

Ao geólogo Geraldo Melo pela leitura de alguns capítulos e pelas valiosas discussões sobre o modelo conceitual hidrogeológico;

Aos colegas geólogos Telma Tostes e José Brás pela importante contribuição ao colocar a disposição as informações das suas pesquisas desenvolvidas nas proximidades da área em aprêço;

Ao engenheiro Josemar pela sua constante ajuda na orientação do manuseio de alguns software e pela realização das medições de descargas nos rios do Mudo, Doce e do Guajiru;

Aos motoristas da Secretaria dos Recursos Hídricos do Rio Grande do Norte, Sr. Chico, Sr. Geraldo e Ribamar pela boa companhia e paciência que tiveram durante a realização do cadastro dos poços tubulares e usuários.

Aos colegas que sempre acreditaram no meu trabalho e pela amizade que adquirimos no convívio profissional: Nivaldo, Graça, Ricardo, Mário, Solange, Fátima Carlos, Herbet, Fátima Rêgo, Hugo e Gustavo;

Ao Coordenador de Gestão dos Recursos Hídricos Ricardo Andrade, pelo apoio e compreensão, quando precisei me afastar das minhas atividades profissionais para concluir o relatório final. 


\section{SUMÁRIO}

\section{Relação das Figuras}

Relação das Tabelas

Relação dos Quadros

Relação dos Anexos

Citação e Dedicatória

\section{Agradecimentos}

\section{Resumo}

\section{Abstract}

\section{0 - INTRODUÇ̃̃O}

1.1 - Localização e Dimensões da Área.

1.2 - Objetivos

1.3 - Metodologia.

3.0 - ASPECTOS FÍSICOS E SÓCIO-ECONÔMICOS ..................................... 13

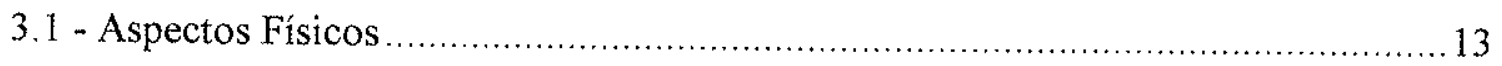

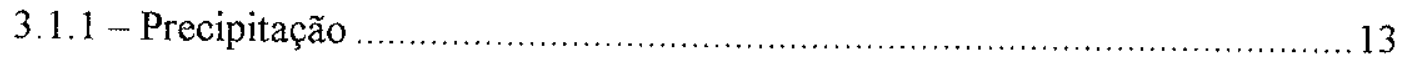

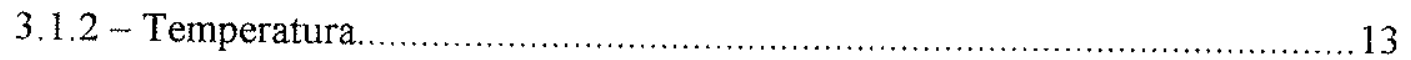

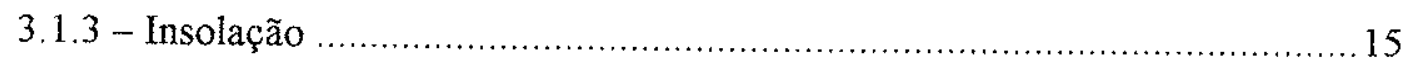

3.1 .4 - Evaporação e Evapotranspiração .................................................... 15

3.1 .5 - Classificação Climática e Balanço Hídrico........................................... 17

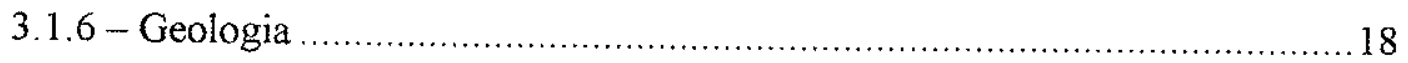

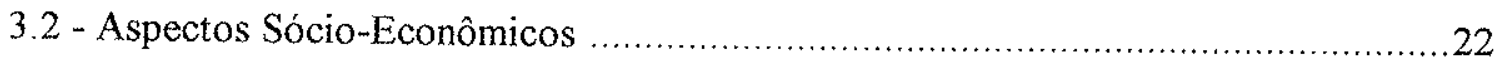

3.2.1 - Recorte para a cidade de Extremoz …......................................... 23

\section{0 - O SISTEMA HÍDRICO SUBTERRÂNEO E A LAGOA DE EXTREMOZ .........24}

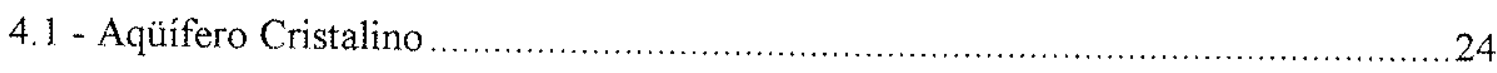

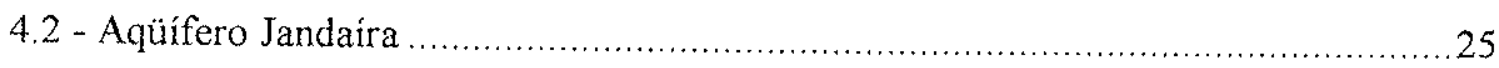

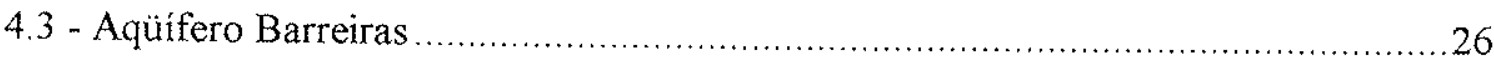

4.3.1 - Evolução do Conhecimento do Aqüifero Barreiras................................26

4.3.2 - O Sistema Aqüífero Dunas/Barreiras na Bacia do Rio Doce ...................27

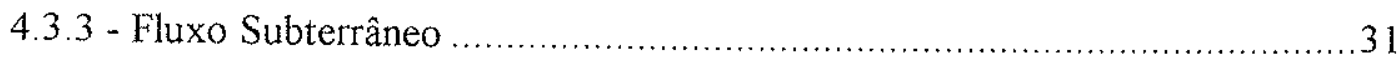


4.3.4 - Estimativa das Reservas e Recursos Explotáveis.

4.3.5 - Estimativa da Contribuição do Volume de Água Proveniente do Sistema Aqüífero Dunas/Barreiras para a Lagoa de Extremoz

4.4 - Aqüífero Aluvial

\section{0 - QUALIDADE DAS ÁGUAS E CARACTERIZAÇ̃̃o HIDROQUÍMICA} 40

5.1 - Águas Superficiais

5.1.1 - Comportamento de alguns Parâmetros Físicos, Químicos, Biológicos e Bacteriológicos - Periodo 1995 a 1996.

5.1.2 - Parâmetros medidos em Campo - Novembro de 1997.

5.1.3 - Recorte para Lagoa de Extremoz - Índices de Qualidade da Água (IQA), do Estado Trófico (IET) e Potabilidade

5.2 - Águas Subterrâneas - Sistema Aqüífero Dunas/Barreiras

5.2.1 - Caracterização Iônica

5.2.2 - Potabilidade

5.2 .3 - Nitrato

5.2.4 - Parâmetros medidos em Campo - Novembro de 1997

\section{0 - USO E OCUPAÇÃO DO SOLO E FONTES POTENCIAIS DE CONTAMINAÇÃO}

6.1 - Uso e Ocupação do Solo

6.1.1 - Leis que Incidem no Uso e Ocupação do Solo .78

6.2 - Fontes Potenciais de Contaminação

6.2.1 - Atividades Industriais

6.2.2 - Lagoas de Estabilização

6.2.3 - Expansão Urbana

6.2.4 - Outras Fontes ou Atividades Potencialmente Contaminantes

\section{0 - SAÚDE PÚBLICA}

7.1 - Indicadores de Saneamento Básico na Bacia do Rio Doce

7.2 - Esquistossomose

7.3 - Hepatite Viral

7.4 - Cólera

7.5 - Febre Tifóide 
7.6 - Patogenicidade do Íon Nitrato. 103

7.7 - Saúde Pública no Contexto do Gerenciamento dos Recursos Hidricos 103

8.0 - APROVEITAMENTO, USOS, DEMANDA, CONSUMO REAL E OFERTA DOS RECURSOS HÍDRICOS

8.1 - Aproveitamento 110

8.2 - Usos 114

8.2.1 - Abastecimento Público 114

8.2.2 - Usos Industrial e Agrícola 120

8.3 - Demanda, Consumo Real e Ofertas

\section{0 - FUNDAMENTOS E ESTRATÉGIAS PARA O GERENCIAMENTO DAS ÁGUAS} SUBTERRÂNEAS NO CURSO INFERIOR DA BACIA DO RIO DOCE 129

9.1 - Aspectos Conceituais da Gestão dos Recursos Hídricos. 130

9.2 - Aproveitamento das Águas 130

9.3 - Experiências Internacionais 131

9.4 - Experiência Brasileira 136

9.4.1 - Arcabouço Jurídico-Institucional Existente 137

9.4.2 - Sistema Nacional Integrado de Gestão dos Recursos Hídricos 140

9.5 - Experiência no Estado do Rio Grande do Norte..... 141

9.5.1 - Leis Ambientais que Antecederam a Legislação Estadual dos Recursos Hídricos

9.5.2 - Histórico da Gestão dos Recursos Hídricos no Estado do RN e Atual Arcabouço Jurídico-Institucional

9.6 - Estratégias Para a Implementação da Gestão das Águas Subterrâneas no Curso Inferior da Bacia do Rio Doce 148

9.6.1 - Associação dos Usuários 150

9.6.2 - Comitê de Bacia 153

9.6.3 - Concessão de Licença Para Construção de Obras de Infra Estrutura Hidrica 


\section{RELACÃO DAS FIGURAS}

N. Figura

Pág.

Figura 1.1 Localização da área

Fonte: (CASTRO, 2000)

Figura.3.1 Variação de dados meteorológicos

Fonte: (DNMET Posto Jacumã Ceará Mirim - 1961 - 1990).

Figura 3.2 Disponibilidade de água no solo

Fonte:DNMET Posto Jacumã/Ceará Mirim -1961 a 1990) 18

Figura 3.3 Geologia da área

Fonte: (CASTRO, 2000)

Figura 3.4 Municípios inseridos na Bacia do Rio Doce

Fonte: (CASTRO, 2000) 22

Figura 4.1 Seções Hidrogeológicas $\mathrm{AB}$ e BC

Fonte: (CASTRO, 2000).

Figura 4.2 Seções Hidrogeológicas CD, EF e WZ

Fonte: (CASTRO, 2000)

Figura 4.3 Potenciometria do Sistema Aqüifero Dunas/Barreiras no curso inferior da Bacia do Rio Doce

Fonte: (CASTRO, 2000).

Figura 4.4 Parâmetros estimados relacionados ao Sistema Aqüífero Dunas/Barreiras no curso inferior da Bacia do Rio Doce

Fonte: (CASTRO, 2000)

Figura 4.5 Simulação preliminar das entradas e saídas anuais de água na lagoa de Extremoz

Fonte: (CASTRO, 2000)

Figura 5.1 Localização dos pontos de amostragem das análises físicas, químicas, biológicas e bacteriológicas realizadas pela CAERN no período de 1995 a 1996

Fonte: (CASTRO, 2000).

Figura 5.2 Comportamento da alcalinidade total no perfil longitudinal Rio do Mudo(Br406)/Rio Doce

Fonte: (CASTRO, 2000).

Figura 5.3 Comportamento dos Sólidos Totais Dissolvidos (STD) no perfil longitudinal rio do Mudo - Rio Doce no periodo de 1995 a 1996

Fonte: (CASTRO, 2000). 
Figura 5.4 Relação entre as concentrações de cloreto $(\mathrm{Cl})$ e as precipitações nos Rios Guajiru, do Mudo e Lagoa de Extremoz no período de março/1995 a março/1996

Fonte: (CASTRO, 2000)

Figura 5.5 Zoneamento do $\mathrm{pH}$, (a), Condutividade Elétrica (b) e Sólidos Totais Dissolvidos (STD) (c), nas águas superficiais dos cursos médio e inferior da Bacia do Rio Doce, novembro/98

Fonte: (CASTRO, 2000).

Figura 5.6 Locais onde foram efetuadas as amostragens para a avaliação do IQA

Fonte: (DUARTE, 1999).

Figura 5.7 Variação espaço-temporal do IQAA E IQAM, na lagoa de Extremoz, no período de dezembro/1996 a dezembro/1997

Fonte:(DUARTE, (1999).

Figura 5.8 Diagrama Triangular de Piper

Fonte: (CASTRO, 2000).

Figura 5.9 Diagrama de Stiff

Fonte: (CASTRO, 2000),

Figura 5.10 Fontes e caminhos do nitrogênio no ambiente sub-superficial

Fonte: (FREEZE \& CHERRY, 1979)

Figura 5.11 Contaminações pontuais de nitrato na Bacia do Rio Doce (a) e especificamente na Zona Norte de Natal

Fonte: (CASTRO, 2000)

Figura 5.12 Evolução dos teores de nitrato na Indústria Guararapes Têxtil

Fonte: (CASTRO, 2000)

Figura 5.13 Comportamento da Condutividade Elétrica, Cloreto e Nitrato no período de 1987 a 1996 na Indústria Parmalat

Fonte: (CASTRO, 2000).

Figura 5.14 Zoneamento do pH, (a), Condutividade Elétrica (b) e Sólidos Totais Dissolvidos (STD) (c), nas águas subterrâneas da Bacia do Rio Doce, novembro/98

Fonte: (CASTRO, 2000)

Figura 6.1 Uso e ocupação do solo na Bacia do Rio Doce

Fonte: (CASTRO, 2000)

Figura 6.2 Vista parcial do uso e ocupação do solo na Bacia do Rio Doce

Fonte: (CASTRO, 2000). 
Figura 6.3 Vista parcial do uso e ocupação do solo na Bacia do Rio Doce

Fonte: (CASTRO, 2000)

Figura 6.4 Disposição das indústrias

Fonte: (Secretaria da Indústria e do Comércio/RN, 1999

Figura 6.5 Produção média diária de efluentes industriais

Fonte: (CAERN, 1996)

Figura 6.6 Produção média mensal de efluentes gerados pelas indústrias

Fonte: (CAERN, 1996)

Figura 6.7 Sistema das lagoas de estabilização do distrito industrial

Fonte: (MELO, 1998).

Figura 7.1 Ciclo de contaminação viral do meio hídrico

Fonte: (CÉCCILLON, 1998)

Figura 7.2 Casos de ocorrência de esquistossomose na Bacia do Rio Doce no período de 1976 a 1996

Fonte: (Fundação Nacional de Saúde- FNS)

Figura 7.3 Casos notificados de hepatite viral no período de 1993 a 1996

Fonte: (Secretaria de Saúde do Estado do Rio Grande do Norte)

Figura 7.4 Casos confirmados de cólera no período de 1992 a 1996

Fonte: (Secretaria de Saúde do Estado do Rio Grande do Norte).

Figura 8.1 Localização da captação da CAERN na Lagoa de Extremoz

Fonte: (CASTRO, 2000).

Figura 8.2 Relação entre poços e cacimbões cadastrados

Fonte: (CASTRO, 2000).

Figura 8.3 Situação dos poços cadastrados nos municípios inseridos na bacia do Rio Doce

Fonte: (CASTRO, 2000)..

Figura 8.4 Localização dos pontos cadastrados

Fonte: (CASTRO, 2000).

Figura 8.5 Colunas construtivas e litológicas dos poços localizados nas unidades industriais

Fonte: (CASTRO, 2000).

Figura 8.6 Colunas construtivas e litológicas dos poços localizados nas unidades industriais

Fonte: (CASTRO, 2000). 
Figura 8.7 Colunas construtivas e litológicas dos poços do Sistema de Abastecimento Público - CAERN

Fonte: (CASTRO, 2000).

Figura 8.8 Colunas construtivas e litológicas dos poços do Sistema de Abastecimento Público - SAAE

Fonte: (CASTRO, 2000).

Figura 8.9 Usos dos poços tubulares e poços amazonas na Bacia do Rio Doce

Fonte: (CASTRO, 2000).

Figura 8.10 Perfil dos usuários dos poços

Fonte: (CASTRO, 2000).

Figura 8.11 Ilustração esquemática dos diversos usos dos recursos hídricos na Bacia do Rio Doce

Fonte: (CASTRO, 2000)

Figura 8.12 Consumo real de águas superficiais e subterrâneas na Bacia do Rio Doce

Fonte: (CASTRO, 2000)

Figura 8.13 Comportamento das demandas estimadas para o ano de 2010, mostrando a possibilidade de ocorrência de uma das situações indicadas Fonte: (CASTRO, 2000).

Figura 9.1 Sistema de Gerenciamento Integrado dos Recursos Hídricos do Estado do Rio Grande do Norte

Fonte: (CASTRO, 2000).

Figura 9.2 Estrutura organizacional da Secretaria dos Recursos Hídricos do Estado do Rio Grande do Norte

Fonte:(SERHID/RN, 1997)

Figura 9.3 Unidades básicas de apoio ao gerenciamento integrado dos recursos hídricos na Bacia do Rio Doce

Fonte: (CASTRO, 2000).

Figura 9.4 Fluxograma dos procedimentos para licenciamento de obras hidráulicas Fonte:(SERHID/RN, 1997)

Figura 9.5 Fluxograma dos procedimentos para a expedição da outorga do direito de uso da água

Fonte:(SERHID/RN, 1997). 


\section{RELAÇÃO DAS TABELAS}

\section{N. ${ }^{\circ}$ Tabela}

Pág.

Tabela 3.1 Evapotranspiração potencial no periodo de $1931-1960$

Fonte: (MELO, 1995)

Tabela 3.2 Evapotranspiração potencial no período de 1961 a 1990

Fonte: (DNMET Posto de Jacumã - Ceará Mirim/RN).

Tabela 3.3 Balanço hídrico segundo Thornthwaite

Fonte: (DNMET Posto Jacumã - Ceará Mirim/RN).

Tabela 4.1 Parâmetros dimensionais do Aqüífero Jandaíra

Fonte:(DINIZ FILHO, 1999).

Tabela 4.2 Parâmetros dimensionais do Sistema Aqüifero Dunas/Barreiras

Fonte: (CASTRO, 2000)

Tabela 4.3 Descargas do fluxo subterrâneo do Sistema Aqüifero Dunas/Barreiras no curso inferior da Bacia do Rio Doce

Fonte: (CASTRO, 2000)

Tabela 4.4 Resumo dos valores estimados relacionados ao Sistema Aqüífero

Dunas/Barreiras do curso inferior da Bacia do Rio Doce

Fonte: (CASTRO, 2000).

Tabela 4.5 Parâmetros utilizados em uma simulação preliminar das entradas e saídas anuais de água na lagoa de Extremoz

Fonte: (CASTRO, 2000)

Tabela 5.1 Resumo dos resultados obtidos para alguns parâmetros físicos, químicos, biológicos e bacteriológicos no período de 1995 a 1996 Fonte: (CAERN).

Tabela 5.2 Medições obtidas em campo, Novembro/98

Fonte: (CASTRO, 2000)

Tabela 5.3 Parâmetros e pesos para cálculo do IQA

Fonte: (DUARTE, 1999).

Tabela 5.4 Classificação de águas naturais, conforme o IQA

Fonte: (GUAZZELLI \& OTTA, 1979).

Tabela 5.5 Distribuição espaço-temporal do índice de qualidade da água (aditivo e multiplicativo) da lagoa de Extremoz/RN, (período de dezembro/96 a dezembro/97)

Fonte; (DUARTE, 1999) 
Tabela 5.6 Padrões de Potabilidade das águas e valores determinados Fonte: (CASTRO, 2000).

Tabela 5.7 Resumo dos tipos de classificações iônicas obtidas

Fonte: (CASTRO, 2000).

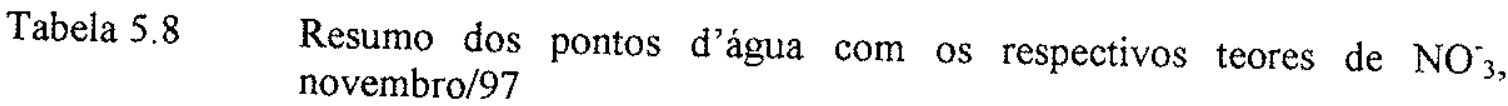

Fonte: (CASTRO, 2000)

Tabela 5.9 Resumo dos parâmetros medidos em campo

Fonte: (CASTRO, 2000)

Tabela 6.1 Resumo das principais informações levantadas no cadastro das unidades industriais

Fonte: (CASTRO, 2000).

Tabela 6.2 Volumes dos efluentes industriais registrados pela CAERN

Fonte: (CAERN).

Tabela 6.3 Categoria do perigo potencial para as águas subterrâneas devido as atividades industriais

Fonte: (CASTRO, 2000), Tabela 6.4 Resumo das principais características dos principais fertilizantes

Fonte:(VRBA \& ROMIJNE, 1986).

Tabela 7.1 Principais Indicadores de saneamento básico, da cidade de Extremoz Fonte: (SERHID/RN, 1998b)

Tabela 7.2 Registros de ocorrência de esquistossomose na bacia do Rio Doce, no período de 1976 a 1996

Fonte: (Fundação Nacional de Saúde - FNS).

Tabela 7.3 Casos notificados de doenças de veiculação hídrica no período de 1989
a março/99

Fonte: (Secretaria de Saúde Pública do Estado do RN). Tabela 7.4 Casos confirmados de doenças de veiculação hídrica no período de 1992
a março/99

Fonte: (Secretaria de Saúde Pública do Estado do RN).

Tabela 8.1

Projeção das populações e demandas calculadas para os anos 2000 , 2005 e 2010

Fonte: (CASTRO, 2000) 
Tabela 8.2 Comparação entre os valores estimados das demandas calculadas e consumo real no ano 2000 , e demandas estimadas para o ano 2010 incluindo os índices de desperdícios

Fonte: (CASTRO, 2000)

Tabela 8.3 Comportamento da demanda total estimada de águas subterrâneas (aqüifero Barreiras), para o ano 2010

Fonte: (CASTRO, 2000).

\section{RELAÇÃO DOS QUADROS}

Quadro1.1 Métodos utilizados para análise dos parâmetros de qualidade das águas

Fonte: (Laboratório de Água e Solo-DATANORTE)

Quadro 5.1 Impurezas mais freqüentes encontradas nas águas naturais

Fonte: (TCHOBANOGLOUS \& SCHROEDER, 1987).

Quadro 7.1 Doenças de veiculação hídrica modificado

Fonte:(ROUQUAYROL, 1993)

Quadro 7.2 História natural e prevenção de doenças

Fonte: (LEAVEL \& CLARK, 1976).

Quadro 9.1 Principais usos, caráter e efeitos da poluição nas águas

Fonte:(Adaptado de NAÇÕES UNIDAS, 1976 e BARTH et al., 1987).

Quadro 9.2 Resumo do diagnóstico realizado na Bacia do Rio Doce

Fonte: (CASTRO, 2000)

Quadro 9.3 Aplicações de métodos de delineamentos de APP e locais onde foram utilizados

Fonte:(CLEARY, 1992).

Quadro 9.4 Resumo das características dos principais fertilizantes agrícolas

Fonte: (VRBA \& ROMIJN, 1986) 167

\section{RELAÇÃO DOS ANEXOS}

Anexo $01 \quad$ Cadastro dos poços tubulares e cacimbões

Fonte: (CASTRO, 2000) 188

Anexo 02 Resultados das análises físicas, químicas, biológicas e bacteriológicas das águas superficiasi do curso inferior da Bacia do Rio Doce, no período de 1995 a 1996

Fonte: (CAERN).

Anexo 03 Parâmetros físicos e químicos das águas subterrâneas e superficiais Fonte: (CASTRO, 2000) 


\section{RESUMO}

A área estudada compreende a Bacia Hidrográfica do Rio Doce com uma área de drenagem de $338 \mathrm{~km}^{2}$, o equivalente a $0,64 \%$ da superficie estadual, tendo como formadores os rios Guajiru e Mudo. Dispõe de um elevado potencial hídrico, representado pelas águas subterrâneas do aqüifero Barreiras e da lagoa de Extremoz, reservas estratégicas de grande alcance sócio-econômico que suprem satisfatoriamente as demandas d'água para a indústria, população urbana e irrigação.

No curso inferior da bacia estudada, destaca-se o distrito industrial e os núcleos urbanos, que abrange a cidade de Extremoz e parte da zona norte de Natal, retratando uma infra-estrutura social precária, onde $67,6 \%$ dos domicilios possuem sistema de abastecimento de água inadequado ou seja, sem canalização interna.. O percentual de domicílios servidos pela coleta de lixo é de $19,8 \%$, os domicilios que têm o lixo queimado ou enterrado correspondem a $53,7 \%$ e aqueles cujo lixo é jogado clandestinamente representam $26,5 \%$.

O Índice de Qualidade da Água (IQA), calculado segundo os métodos aditivo e multiplicativo (DUARTE, 1999), caracterizou a água da lagoa de Extremoz entre boa e ótima. No entanto, em decorrência do acentuado crescimento urbano e do desenvolvimento industrial, nesta região, constatou-se que este potencial hídrico está submetido aos efeitos de ações impactantes, o que poderá causar significativas restrições no atendimento às demandas futuras.

A ausência de rede de esgotos e consequentemente o uso de sistemas de saneamento com disposição local de efluentes, associados a uma área cujo comportamento é de um sistema livre, o que propicia elevadas taxas de infiltração das águas pluviais, caracteriza o ambiente como sendo de alta vulnerabilidade para a contaminação das águas subterrâneas. O reflexo deste quadro já se faz presente nas águas de alguns poços tubulares do sistema de abastecimento público, cujos teores de nitrato já são superiores a $45 \mathrm{mg} / \mathrm{L}$, e na incidência de doenças de veiculação hídrica, como esquistossomose, cólera, hepatite viral e verminoses.

As reservas reguladoras do sistema aqüifero Dunas/Barreiras, no curso inferior da bacia, foram estimadas em $76,0 \times 10^{6} \mathrm{~m}^{3} / \mathrm{ano}$, equivalente a vazão do fluxo subterrâneo natural. As reservas permanentes são da ordem de $354 \times 10^{6} \mathrm{~m}^{3}$. O volume atual explotado de águas subterrâneas (aqüífero Barreiras), atinge uma cifra de $21,3 \times 10^{6} \mathrm{~m}^{3} /$ ano. A demanda de águas subterrâneas para o ano 2010 foi estimada em $37,8 \times 10^{6} \mathrm{~m}^{3} / \mathrm{ano}$, correspondente a $49,7 \%$ das reservas reguladoras, caso mantenha-se a retirada do mesmo volume de água 
superficial atual. Nesse caso, verificou-se, que há uma necessidade de gerenciamento intensivo, considerando que em 2010 a demanda compreenderá $50 \%$ das reservas reguladoras. Além da componente "quantidade" existe a degradação da qualidade dos mananciais, o desenvolvimento urbano e industrial aliados à falta de saneamento básico e, consequentemente incidências significativas de doenças de veiculação hidrica.

Diante desse quadro, o estudo teve como objetivo geral realizar um diagnóstico da bacia e indicar estratégias que poderão ser contempladas na implementação do gerenciamento das águas subterrâneas no curso inferior da bacia hidrográfica estudada. 


\begin{abstract}
The area studied comprises the watershed of Doce river with a drainage area of $338 \mathrm{~km}^{2}$ which is equivalent to $0.64 \%$ of the state surface, being formed by Guajiru and Mudo rivers. It has a high hydric potential represented by groundwater of the Dunes/Barreiras Aquifer System and Extremoz lagoon which are strategic resources of great socio-economic extent that satisfactorily supply the water demands for industry, urban population and irrigation.

Along the lower course of the studied basin, the industrial district and the urban sites which comprises Extremoz city and part of northern zone of Natal are prominent. These display a precarious social infra-structure where $67.6 \%$ of the dwellings have na inadequate water supply system, that is, without inward canalization. The percentage of dwellings being served by refuse collect is $19.8 \%$, those dwellings which burn or bury their refuse correspond to $53.7 \%$ and those that have na illegal throw-away manner for their refuse represent $26.5 \%$.

The Water Quality Index (WQI), calculated according to the additive and multiplicative methods, DUARTE (1994), characterzed the water of Extremoz lagoon between good and excellent. However, due to the marked urban growth as well as the industrial development, in this region, it was found that this hydric potential is subject to the effects of impact actions which may cause significant restrictions on the supply of future demands.

The lack of sanitary sewerage network, and as a result, the use of sanitation systems with local disposition of waste water together with an area that presents a behavior of a not-confined system, which gives rise to high infiltration rates of the rains waters, characterizes the environment as having a strong vulnerability for the contamination of the ground water. The reflex of this situation is already present in the waters of some wells in the public water supply system, the nitrate content of which are superior to $45 \mathrm{mg} / \mathrm{L}$ as well as in the incidence of hydric veiculation diseases, such as cholera, virus hepatitis and verminosis The regulator stores of the Dunes/Barreiras Aquifer System, in the lower course of the basin, were estimated at $76.0 \times 10^{6} \mathrm{~m}^{3} /$ year, equal to the natural groundwater flow yield. The permanent stores are about $354 \times 10^{6} \mathrm{~m}^{3}$. The current volume of groundwater exploited (Dunes/Barreiras Aquifer System) reaches the figure of $21.3 \times 10^{6} \mathrm{~m}^{3} /$ year. The demand of groundwater for the year 2010 was estimated at $37.8 \times 10^{6} \mathrm{~m}^{3} /$ year, which corresponds to $49.7 \%$ of the regulator stores if it is maintained the explotation of the same present volume of surface water. In this case, it was found that there is a need for intensive planning,
\end{abstract}


considering that in 2010 the demand will comprise $50 \%$ of the regulator stores. Besides the component "quantity", there is a quality degradation of the water bodies, the urban and industrial development together with the lack of basic sanitation system, and therefore, significant incidences of hydric veiculated diseases.

Taking this situation, the general purpose of this study was to diagose the basin and to indicate strategies that may be considered in the fulfillment of the planning of groundwater in the lower course of the watershed studied. 
O processo de desenvolvimento econômico e social de uma região está intimamente relacionado com a forma de utilização dos seus recursos naturais. Sendo a água uma componente fundamental, a mesma tem sido nas últimas décadas alvo de preocupação quanto ao seu planejamento e gerenciamento, colocando para os órgãos gestores dos recursos hídricos a responsabilidade de atender os usuários, de forma a fornecer água de qualidade que atenda aos múltiplos usos.

Segundo as últimas estimativas $97,3 \%$ correspondem à água do mar e apenas $2,7 \%$ à água doce. Desta, $0,36 \%$ está nos rios, lagos, pântanos e similares e $22,4 \%$ são águas subterrâneas e umidade do solo.

O Brasil detém $8 \%$ de toda água doce do planeta e estima-se ainda que o país detenha cerca de 112 bilhões de metros cúbicos de água subterrânea. Segundo REBOUÇAS (1994), as águas subterrâneas armazenadas nos grandes aqüiferos das bacias sedimentares apresentam tempos de renovação que ultrapassam com freqüência, a escala da existência humana, ou de vida útil de seus projetos. Logo, estas reservas são consideradas como praticamente não renováveis.

Os problemas relacionados com a água na atualidade é um dos desafios para o próximo milênio, o que já vem sendo alertado desde a década de setenta, quando foi caracterizada uma crise mundial e que levou a sociedade a questionar seus valores e seus modelos de desenvolvimento.

A carta Européia da Água, proclamada pelo Conselho da Europa em Estrasburgo, França, em maio de 1968, definiu doze princípios para inspirar as legislações dos países membros do Conselho da Europa.

Eventos de alcance mundial, como a Conferência do Estocolmo de 1972, culminaram com a consciência da necessidade de estabelecer um novo paradigma de desenvolvimento menos agressivo em termos ambientais.

A conferência das Nações Unidas sobre Meio Ambiente e Desenvolvimento no Rio de Janeiro em 1992, conhecida como Rio-92 foi um acontecimento marcante neste processo, de onde saiu fortalecido o modelo de desenvolvimento sustentável e resultou no documento Agenda 21, onde foram apresentados objetivos e metas gerais até o século XXI, para todos os países signatários.

O Plano de Ação de Mar Del Plata, aprovado pela conferência das Nações Unidas sobre a água em 1977 apresentou a seguinte premissa: "todos os povos, quaisquer que sejam 
as condições sociais e econômicas, têm direito ao acesso à água potável em quantidade e qualidade à altura de suas necessidades básicas".

Atualmente uma em cada três pessoas no mundo ainda não conta com essas duas exigências básicas de saúde e dignidade. De acordo com dados estatísticos publicados pela Companhia de Pesquisas e Recursos Minerais, em A água em Revista (1996) no início do próximo milênio mais da metade da população mundial estará vivendo em zonas urbanas. Até o ano 2025, essa proporção chegará aos $60 \%$, compreendendo cerca de 5 bilhões de pessoas.

Em março de 1998, Paris abrigou cientistas de todo o mundo, que debateram sobre esses problemas e constataram que o desenvolvimento dos países emergentes poderá ser afetado e serão desencadeados conflitos entre nações em regiões já instáveis politicamente como o Oriente Médio e a África. De acordo com o relatório da Organização das Nações Unidas (ONU), divulgado após a Conferência Internacional sobre a água em Paris, atualmente vive-se uma crise global da maior gravidade e se os atuais meios de exploração dos recursos hídricos não forem revistos, dois terços da população mundial vão passar sede até 2005 .

Alertou o presidente da França Jacque Chirac ao final do encontro: "No planeta há 70 regiões em confronto pelo controle de fontes de água potável".

Dentro deste contexto é imprescindivel dedicar atenção especial aos efeitos crescentes da urbanização sobre a demanda e o consumo de água e ao papel decisivo desempenhado pelas autoridades na gestão do abastecimento, uso e tratamento da água.

É urgente a necessidade de ser adotado o entendimento da água a partir do binômio quantidade/qualidade, considerar as águas superficiais e subterrâneas, contemplando todos os seus usos, segundo uma perspectiva de gestão global, tendo a bacia hidrográfica como unidade básica de planejamento e gerenciamento. Com efeito as bacias são consideradas como um todo, indivisivel, cujo aproveitamento deve ser o mais otimizado possivel, no intuíto de proporcionar um melhor desenvolvimento econômico e social à região e isso somente é possível a partir do conhecimento das características e necessidades locais.

\section{1 - LOCALIZAÇÃO E DIMENSÕES DA ÁREA}

Na figura 1.1 está representada a localização da área de estudo. A bacia do rio Doce situada entre as coordenadas UTM de 9.364 a $9.376 \mathrm{~km}$ norte e 208 a $256 \mathrm{~km}$ leste possui uma área de drenagem de $338 \mathrm{~km}^{2}$, o equivalente a $0,64 \%$ da superficie estadual, tendo como formadores os rios Guajiru, Mudo, Doce e a lagoa de Extremoz. 


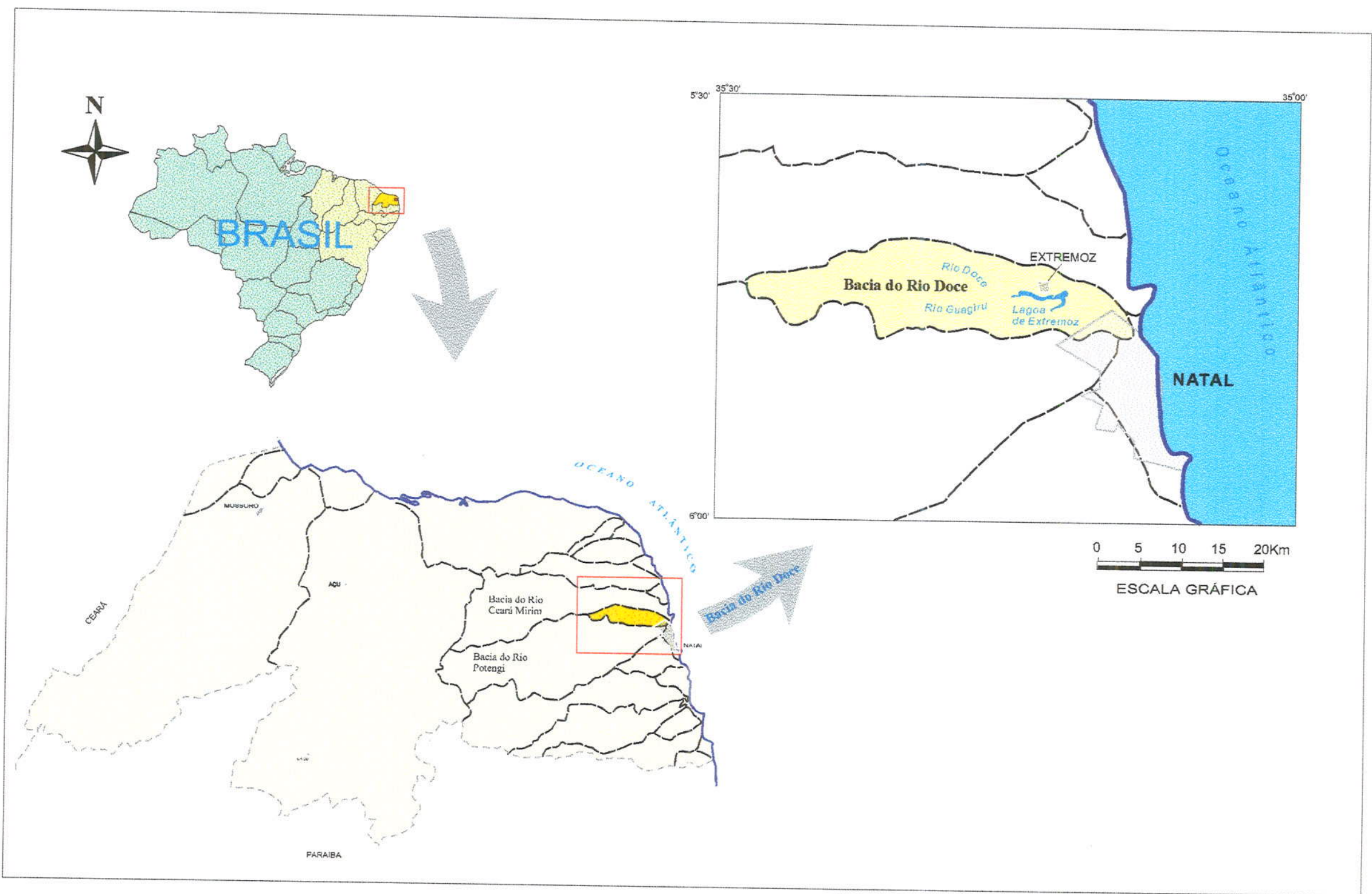

Figura 1.1 - Localização da área Fonte: (CASTRO, 2000) 
Engloba parte dos municípios de Extremoz, Ceará Mirim, Natal, São Gonçalo do Amarante, Taipu e Telmo Marinho.

Limita-se ao norte e ao noroeste com a bacia hidrográfica do Rio Ceará Mirim e ao sul e ao sudoeste com a bacia hidrográfica do rio Potengi. A leste limita-se com o oceano atlântico.

Inclui em seu domínio, o Distrito Industrial de Extremoz, e um dos principais mananciais de água doce superficial do Estado, que é a Lagoa de Extremoz, atualmente utilizada no abastecimento público da Zona Norte da cidade de Natal, nos projetos de irrigação e atende à função de harmonia paisagística e de atividades recreativas da região.

\section{2 - OBJETIVOS}

O planejamento e conseqüente gerenciamento dos recursos hídricos de uma bacia hidrográfica requer como base o conhecimento das peculiaridades da unidade de gestão, como também os anseios dos seus usuários, portanto é com esta visão holística que o presente estudo contemplou os seguintes objetivos:

- Levantamento do uso e ocupação do solo;

- Modelo conceitual hidrogeológico;

- Conhecimento do potencial hídrico, consumo atual e demandas futuras dos recursos hídricos;

- Caracterização da qualidade das águas;

- Conhecimento da ocorrência das doenças de veiculação hídrica.

Os objetivos apontados permitiram propor estratégias que poderão ser contempladas na implementação do gerenciamento das águas subterrâneas no curso inferior da Bacia do Rio Doce.

\section{3 - METODOLOGIA}

A metodologia utilizada neste estudo compreendeu três fases: A primeira contemplou a organização, homogeneização e interpretação dos dados levantados e do cadastro das estruturas hídricas, usuários e fontes de contaminação. A segunda etapa constituiu-se dos trabalhos de campo, em que foram realizadas as seguintes atividades: as coletas de água para análises físicas e químicas; as campanhas de medições em campo dos 
parâmetros físicos e químicos nos mananciais de superfície; as medições dos níveis d'água superficiais e subterrâneas e a reambulação de campo para a e atualização do mapa de uso e ocupação do solo. A terceira etapa compreendeu a descrição dos resultados obtidos a partir dos dados levantados e das atividades de campo, que resultou em um diagnóstico da área estudada e em consequêencia os fundamentos e estratégias para o gerenciamento das águas subterrâneas no curso inferior da bacia. A seguir as fases mencionadas.

\section{Primeira Fase}

Inicialmente foi efetuado um levantamento de todos os dados, informações e estudos já realizados de interesse à pesquisa, de modo que o planejamento desta etapa contemplou os seguintes alvos:

- Levantamento e análises dos dados bibliográficos e cartográficos;

Foi efetuado um levantamento de todos os trabalhos realizados de interesse à pesquisa, coleta de dados e materiais auxiliares como:

- Cartas altimétricas em escala de 1:100.000;

- Fotografias aéreas em escala 1:40.000;

- Imagens de satélites tipo Spot, escala 1:50.000;

- Fichas técnicas de poços, com os perfis construtivos e litológicos;

- Análises físicas, químicas e bacteriológicas das águas subterrâneas e superficiais;

- Levantamento de dados no Instituto Brasileiro de Geografia e Estatítica, (IBGE) relacionados a população e atividades sócio-econômicas, dos municípios inseridos na bacia;

- Levantamento dos estudos técnicos científicos existentes relacionados a área estudada;

- Levantamento dos dados climatológicos;

- Digitalização das cartas existentes:

Foram realizadas digitalizações das cartas existentes, tendo sido amarradas ao sistema de projeção UTM, e digitalizados todos os detalhes planialtimétricos e altimétricos.

- Reconhecimento Geral de Campo;

Foram utilizados dois dias de campo para o reconhecimento geral da bacia, cujo principal objetivo foi verificar o comportamento da área no que se referia aos usos da água, 
aos órgãos de apoio dos municípios inseridos na bacia, e aos demais aspectos que interfeririam no planejamento do cadastro das estruturas hídricas e usuários de água.

- Caracterização física da bacia;

Com base nos dados climatológicos obtidos na Empresa de Pesquisas Agropecuárias do Rio Grande do Norte, (EMPARN) nos estudos geológicos e geomorfológicos realizados na região foi feita a caracterização física da bacia.

- Cadastramento dos usuários dos recursos hídricos, das estruturas hídricas, e das fontes potenciais de contaminação.

Para a realização desse cadastramento foram utilizados 45 dias de campo, que constou do preenchimento de formulários elaborados especificamente para a obtenção das informações sobre os usuários de água, as estruturas hídricas e as fontes de contaminações.

Todas as estruturas hídricas cadastradas assim como as fontes de contaminações foram plotadas nas cartas digitalizadas. O mapa com os pontos visualizados serviu como base para a seleção das localizações dos poços e cacimbões adequados para monitoramento.

As informações obtidas foram tratadas, o que permitiu fazer uma seleção dos poços e cacimbões para terem seus níveis monitorados, e dos pontos adequados para a realização das análises físicas e químicas. As tabelas A-J anexo 01, compreendem as informações sobre o cadastro dos usuários, poços tubulares e dos cacimbões.

- Tratamento das análises físicas, químicas e biológicas levantadas;

A partir do levantamento realizado das análises físicas, químicas e biológicas nos Laboratórios da Companhia de Águas e Esgotos do Rio Grande do Norte (CAERN) e da Fundação Nacional de Saúde (FNS), foram selecionadas àquelas com identificação da fonte (poço, rio ou lagoa). Em seguida todas as informações foram cadastradas em um banco de dados e tratadas em diferentes níveis, considerando: tipo de Manancial, Tipo de Aqüífero e os Grupos de Elementos Químicos, Físicos ou Biológicos que pudessem ser correlacionados.

As tabelas A-F anexo 02, apresentam os dados das análises fisicas, químicas e biológicas, dos corpos de águas superficiais, monitorados pela CAERN no período de 1995 a 1996. As tabelas $\mathrm{A}-\mathrm{E}$ anexo 03, compreendem os resultados das análises físicas e químicas das águas subterrâneas e superficiais. 
- Campanhas de medições dos níveis de água nos mananciais subterrâneos e superficiais;

Em um período de dois anos foram realizadas três campanhas de medições dos niveis de água nos poços e cacimbões selecionados para monitoramento. A primeira foi realizada durante a elaboração do cadastro em setembro/97, a segunda campanha ocorreu no final do verão em março de 1998 e a terceira medição em novembro/98.

Medições de descargas nos rios do Mudo, Guajiru e Doce

$\mathrm{O}$ aparelho utilizado nas medições foi um micromolinete digital e foi seguida a seguinte metodologia: para profundidades, superiores a $60 \mathrm{~cm}$, mediu-se as velocidades em duas profundidades situadas à $20 \%$ e $80 \%$ da profundidade, a partir da superficie da água; para profundidades inferiores a $60 \mathrm{~cm}$, mediu-se a velocidade a $60 \%$ desta profundidade, a partir da superficie da água. Foram adotados espaçamentos horizontais de $50 \mathrm{~cm}$ de largura. A vazão final é dada pelo produto das velocidades médias e pelas respectivas áreas de influência de cada trecho.

- Campanhas de coletas de águas superficiais e subterrâneas para análises fisicas e químicas;

O planejamento de avaliação da qualidade das águas superficiais e subterrâneas baseou-se em informações preexistentes e realização de amostragens para análises físicas e químicas das águas superficiais e subterrâneas, que seguiu uma programação criteriosa, compreendendo:

- Definição dos objetivos da Amostragem;

- Escolha dos parâmetros a serem analisados;

- Locais escolhidos para amostragem;

- Seleção dos métodos de análise;

- Coleta de amostras;

\section{Definição dos Objetivos da Amostragem}

A verificação da conformidade das águas estudadas para os usos a que se destinam, com os padrões de qualidade vigente, fixados pela resolução 020/86 do CONAMA, constituiu o objetivo principal da amostragem, visando principalmente:

- verificar a presença e mecanismo de contaminação;

comportamento hidroquímico quanto aos ions dominantes;

Este capítulo direcionado à caracterização da qualidade das águas é uma importante ferramenta que serve para prever os problemas futuros de manejo dos recursos 
hídricos através do estudo das tendências de qualidade das águas ao longo do tempo, o que facilitará o planejamento para o atendimento das necessidades sociais e econômicas dos diversos consumidores.

\section{Escolha dos Parâmetros a Serem Analisados}

A escolha dos parâmetros a serem analisados foi em função do uso e ocupação atual do solo e dos respectivos usos a que as águas se destinam tais como:

- abastecimento humano e animal;

- agricultura (irrigação);

- uso industrial.

\section{Locais Escolhidos para Amostragem}

As variáveis que quantificam e determinam o comportamento da qualidade ambiental das descargas líquidas são funções complexas que estão continuamente sofrendo variações, portanto a seleção dos locais onde foram realizadas as amostragens atendeu aos seguintes requisitos:

- os pontos de amostragens nunca foram próximos às margens dos rios; da lagoa; de tubulações e águas estagnadas;

- as amostras coletadas nos tributários foram escolhidas nos locais mais próximos possiveis da desembocadura;

- na lagoa, durante a amostragem foi considerada a possibilidade de existência de estratificação térmica, com formação de camadas que não se misturam, tendo sido realizadas coletas na superfície em uma localização intermediária e no fundo;

- foram evitados os locais de dificil acesso, uma vez que o objetivo era maximizar o número de coletas em um tempo hábil, facilitando o transporte ao laboratório, atendendo os prazos de conservação exigidos para os requeridos parâmetros;

\section{Coleta das Amostras}

A técnica adotada para a coleta foi em função da natureza da amostra (águas superficiais, (rios ou lagoa e subterrâneas). Os rios que constituem a bacia estudada são de pequeno porte e dessa forma a técnica de amostragem adotada nestes corpos d'água foi a de "Amostragem Simples em Rios de Pequeno e Médio Portes, que consistiu em:

realizar coletas a $50 \mathrm{~cm}$ de profundidade da superfície do rio em seu ponto central no sentido contrário ao da corrente, com auxílio de frascos de vidro, âmbar e polietileno;

para as águas subterrâneas as amostras foram coletadas em poços e cacimbões e foram acondicionadas em frascos plásticos, etiquetados. 
Os elementos físicos e químicos determinados foram: $T^{\circ}$, cor, turbidez, $\mathrm{pH}$, condutividade elétrica, sólidos totais, sólidos dissolvidos, sólidos em suspensão, alcalinidade total, alcalinidade de hidróxido, alcalinidade de carbonato, alcalinidade de bicarbonato, dureza total, $\mathrm{NH}_{3}, \mathrm{NO}_{2}^{-}, \mathrm{NO}_{3}^{-}, \mathrm{Ca}^{++}, \mathrm{Mg}^{++}, \mathrm{Na}^{++}, \mathrm{K}^{+}, \mathrm{Fe}, \mathrm{CO}_{3}^{-}, \mathrm{HCO}_{3}^{-}, \mathrm{SO}_{4}^{-}, \mathrm{Cl}^{-}$. Os métodos utilizados para a análise dos parâmetros de qualidade de água estão mencionados no quadro 1.1 .

Quadro 1.1 - Métodos utilizados para análise dos parâmetros de qualidade das águas.

\begin{tabular}{|l|l|}
\hline PARAMETROS & MÉTODO \\
\hline Temperatura & Leitura direta - Termômetro de Hg \\
\hline Cor & Comparação visual - Padrões de Platina-Cobalto \\
\hline Turbidez & Comparação visual - Padrões de sílica \\
\hline Dureza Total & Volumetria (EDTA) \\
\hline PH & Potenciométrico \\
\hline Sólidos Totais Dissolvidos & Gravimétrico \\
\hline Nitrito & Colorimétrico - N(l-naftil) \\
\hline Nitrato & Colorimétrico - redução por coluna de cádmio cobreado \\
\hline Nitrogênio Amoniacal & Colorimétrico - Nessler \\
\hline Alcalinidade Total & Titulação potenciométrica \\
\hline Cloreto & Volumétrico - nitrato de prata \\
\hline Cálcio & Volumétrico (EDTA) \\
\hline Magnésio & Volumétrico (EDTA) \\
\hline Sódio & Fotometria de chama \\
\hline Potássio & Fotometria de chama \\
\hline Sulfato & Turbidimétrico \\
\hline Ferro & Colorimétrico - fenantrolina \\
\hline
\end{tabular}

Fonte: Laboratório de Água e Solo - Companhia de Processamento de Dados do Rio Grande do Norte (DATANORTE).

Adotou-se para a coleta de todas as amostras, uma ficha apropriada para o registro de dados e das características anormais constatadas durante o procedimento de campo. $\mathrm{O}$ procedimento estabelecido visou:

- identificar corretamente as amostras;

- evitar contaminações cruzadas;

- recolher um volume adequado para as análises; 
- Campanha de medições em campo de pH, Condutividade, Sólidos Totais Dissolvidos e percentuais de sais.

Foram utilizados dois kits com medidores de $\mathrm{pH}$, de condutividade elétrica, sólidos totais, percentual de sais e controle da temperatura. Os equipamentos foram devidamente calibrados no laboratório antes de serem utilizados. As medições foram realizadas em um período de três dias seguidos, para que não houvesse alguma alteração nas medições em função das variações meteorológicas regionais.

- Atualização do mapa de uso e ocupação do solo

A partir de imagens de satélites tipo Spot-2 em escala 1:50.000, ano 1994 e com base em mapas elaborados com imagens de 1989 , foi realizada a atualização do uso e ocupação do solo, com reambulação de campo.

\section{Terceira Fase}

Compreendeu a descrição dos resultados obtidos, onde foram utilzados softs gráficos e os fundamentos científicos, originando um diagnóstico da área que serviu de base para a proposição de estratégias que poderão ser contempladas em um plano de gestão das águas subterrâneas do curso inferior da bacia do rio Doce.

\section{0 - REVISÃO BIBLIOGRÁFICA}

TAHAL/SONDOTÉCNICA (1969) realizou estudo para CAERN, sobre o aproveitamento hidro-agrícola das bacias do rio Ceará Mirim e da Lagoa de Extremoz. Com base nos dados levantados no período de maio de 1968 a março de 1969, foi efetuado o balanço hídrico mensal da lagoa.

FIGUEIREDO (1977) elaborou para a CAERN, um projeto de captação d'água da Lagoa de Extremoz para atender a população da zona norte de Natal, que na época restringiase ao bairro de Igapó e praia da Redinha. Segundo o recenseamento de 1977, a população da zona norte de Natal abrangia 10.000 habitantes.

O referido projeto de captação tinha como meta atender a demanda para os próximos 20 anos (1977-1997), cuja projeção populacional considerada foi de 110.000 habitantes para o ano de 1997, incluindo ainda o desenvolvimento comérciário e industrial.

O manancial da Lagoa de Extremoz apresentava na época os seguintes atrativos para o referido projeto: 
- Pequena distância dos núcleos a serem abastecidos;

- Facilidade de captação por ser considerado no Estado um expressivo reservatório natural de acumulação e regularização. Com base nos estudos da sondotécnica, 1969 , o autor chegou a uma cifra de $60 \times 10^{3} \mathrm{~m}^{3} / \mathrm{dia}$, volume a ser explotado da Lagoa.

- Água de excelente qualidade, que de acordo com as análises das amostras realizadas no dia 04 de maio de 1977 apresentaram as seguintes características:

$\begin{array}{lc}\mathrm{pH} & 7,4 \\ \text { Cloretos } & 63,0 \mathrm{mg} / \mathrm{L} \\ \text { Ferro } & 0,15 / \mathrm{mg} / \mathrm{L} \\ \text { Dureza total } & 0,0 \mathrm{mg} / \mathrm{L} \\ \text { Dióxido de Carbono } & 5,0 \mathrm{mg} / \mathrm{L} \\ \text { Sólidos Dissolvidos } & 143,0 \mathrm{mg} / \mathrm{L}\end{array}$

A PLANAT CONSULTORIA (1982) realizou estudo hidrológico sobre a disponibilidade dos recursos hídricos das bacias hidrográficas das Lagoas de Jiqui, Extremoz, Bonfim e Pium, principais mananciais de superficie existentes na região de Natal e nas suas proximidades. Devido a completa inexistencia de dados fluviométricos, o estudo foi realizado por correlação com rios da região costeira da Paraíba. Os resultados estimaram com $1 \%$ de risco, uma potencialidade hídrica global de $4,486 \mathrm{~m}^{3} / \mathrm{s}$ assim distribuídos: Jiqui $1,0 \mathrm{~m}^{3} / \mathrm{s}$; Extremoz $2,645 \mathrm{~m}^{3} / \mathrm{s} ;$ Bonfim $0,492 \mathrm{~m}^{3} / \mathrm{s} ;$ Pium $0,349 \mathrm{~m}^{3} / \mathrm{s}$.

A COMPANHIA DE TECNOLOGIA DE SANEAMENTO AMBIENTAL, CETESB (1982) em convênio estabelecido com a extinta Superintendência de Desenvolvimento do Nordeste (SUDENE), fez uma avaliação das condições limnológicas da lagoa, objetivando um programa de monitoramento físico-químico e biológico do referido manancial. $O$ estudo realizado caracterizou a água como de boa qualidade mas adverte sobre um possivel processo de eutrofização na lagoa em função do acentuado crescimento urbano à sua volta.

PEREIRA (1993) apresentou estudos sobre a qualidade das águas dos mananciais de superfície utilizados no abastecimento da cidade de Natal entre estes a lagoa de Extremoz. Os dados obtidos através do monitoramento realizado entre fevereiro/1992 a janeiro/1993, foram apresentados através de Índices de Qualidade IQA, que indicaram às condições sanitárias do corpo d’água na época. 
O IQA é um número gerado a partir de nove parâmetros de qualidade de água (oxigênio dissolvido, coliformes fecais, $\mathrm{pH}$, turbidez, $\mathrm{DBO}_{5}$, nitrogênio total, fósforo total, sólidos totais e gradiente de temperatura) e curvas relacionadas aos mesmos. Os índices testados mostraram que de uma maneira geral, a qualidade das águas do manancial se manteve dentro das faixas correspondentes aos diversos usos a que se destinam, apresentandose nas faixas ótima quando aplicou-se o método aditivo e boa para o método multiplicativo. O autor sugere um monitoramento do uso e ocupação do solo na respectiva bacia hidrográfica, que sejam realizadas análises de substâncias tóxicas e uso de indicadores biológicos para complementar o índice de qualidade da água além de um estudo do plâncton (fitoplâncton e zooplâncton).

ARAÚJO (1997) investigou a variação anual da comunidade fitoplanctônica, da clorofila e da produtividade primária. A pesquisa objetivou elucidar o papel dos fatores ambientais na determinação do crescimento das comunidades algais da lagoa e o impacto industrial sobre estes organismos a partir das teorias modernas de sucessão fitoplantônica na ecologia de comunidades.

DUARTE (1999) realizou estudos utilizando Índices do Estado Trófico (IET) e de Qualidade da Água (IQA) para a caracterização limnológica e sanitária das Lagoas de Bonfim, Extremoz e Jiqui (RN). O objetivo principal foi analisar o desempenho dos Índices do Estado Trófico (IET) e de Qualidade da Água (IQA), tendo sido realizadas análises físicas, químicas e microbiológicas das três lagoas.

MELO (1998) coordenou estudos hidrogeológicos desenvolvidos pela CAERN na Zona Norte de Natal, cuja área compreende parte do curso inferior da bacia estudada, que teve como objetivo avaliar as potencialidades hidrogeológicas e os riscos potenciais de contaminação das águas subterrâneas utilizadas no abastecimento da população local. As conclusões do autor, indicam que as águas subterrâneas armazenadas nesta área são da ordem de grandeza de $246 \times 10^{6} \mathrm{~m}^{3} /$ ano e os recursos explotáveis podem atingir a cifra de $46 \times 10^{6}$ $\mathrm{m}^{3}$ /ano. Os estudos também concluiram que em grande parte da área urbanizada, os teores de nitrato já são superiores ao nivel de base geral de $10 \mathrm{mg} / \mathrm{l}$, evidenciando a influência dos efluentes domésticos. Alguns poços do sistema público de abastecimento já se mostram afetados por teores de nitrato elevado e três deles se revelaram com teores superiores a $45 \mathrm{mg} / 1$.

O manancial subterrâneo da zona Norte de Natal constitui uma reserva estratégica de grande importância, tendo em vista a perspectiva de aumentar a curto prazo a oferta d'água no atendimento à população urbana e industrial. 


\section{0 - ASPECTOS FÍSICOS E SÓCIO-ECONÔMICOS}

\section{1 - Aspectos Físicos}

É de fundamental importância que qualquer investigação relacionada aos recursos hídricos de uma determinada região se tenha o conhecimento sobre o comportamento do circuito precipitações, escoamentos, evaporação e o controle que este sistema fechado exerce sobre a atmosfera, a superficie da terra e os reservatórios superficiais e subterrâneos. Neste capítulo serão analisados os elementos que condicionam as reservas de água na Bacia.

\subsection{1 - Precipitação}

De acordo com os dados fornecidos pela Empresa de Pesquisa Agropecuária do Rio Grande do Norte, (EMPARN - Posto Jacumã- Ceará Mirim), a precipitação pluviométrica no médio curso da bacia, no periodo de 1912 a 1976, atingiu um máximo de $2.098 \mathrm{~mm}$ e um mínimo de $382 \mathrm{~mm}$, com média anual de $1.032,65 \mathrm{~mm}$.

As maiores precipitações normalmente ocorrem nos meses de abril, maio e junho e as menores, nos meses de outubro, novembro, dezembro e janeiro (figura 3.1).

No alto curso da Bacia as informações sobre pluviometria no periodo de 1912 a 1976, (Posto Taipu), indicam que a maior precipitação ocorreu no ano de 1974 , atingindo $2.432 \mathrm{~mm}$ e a menor no ano de 1947 , com $306 \mathrm{~mm}$. A média anual obtida nesse mesmo período foi de 737,29 $\mathrm{mm}$.

No baixo curso da bacia foram analisados os dados do posto de Natal, período 1910 a 1979, com uma precipitação máxima de $3.511 \mathrm{~mm}$ e um mínimo de $530 \mathrm{~mm}$, com média anual de $1.563 \mathrm{~mm}$.

3.1 .2 - Temperatura

No médio curso, os dados do posto de Jacumã em Ceará Mirim, período de 1961 a 1990 , indicam uma temperatura média de $25,4^{\circ} \mathrm{C}$ com variações de $24^{\circ}$ a $26,5^{\circ} \mathrm{C}$ e amplitude térmica de $2,5^{\circ} \mathrm{C}$. 
No curso da bacia, posto de Natal na Estação Meteorológica M. A., período 1931 a 1960 , as temperaturas variaram de $24,4^{\circ}$ a $27,3^{\circ} \mathrm{C}$, com média anual de $26,2^{\circ} \mathrm{C}$ e amplitude térmica de $2,9^{\circ} \mathrm{C}$.

Em toda a Bacia os meses mais quentes do ano são dezembro, janeiro e fevereiro que corresponde ao final da estação seca e início das chuvas. Os meses mais frios são de julho a setembro, na estação chuvosa, (figura 3.1).

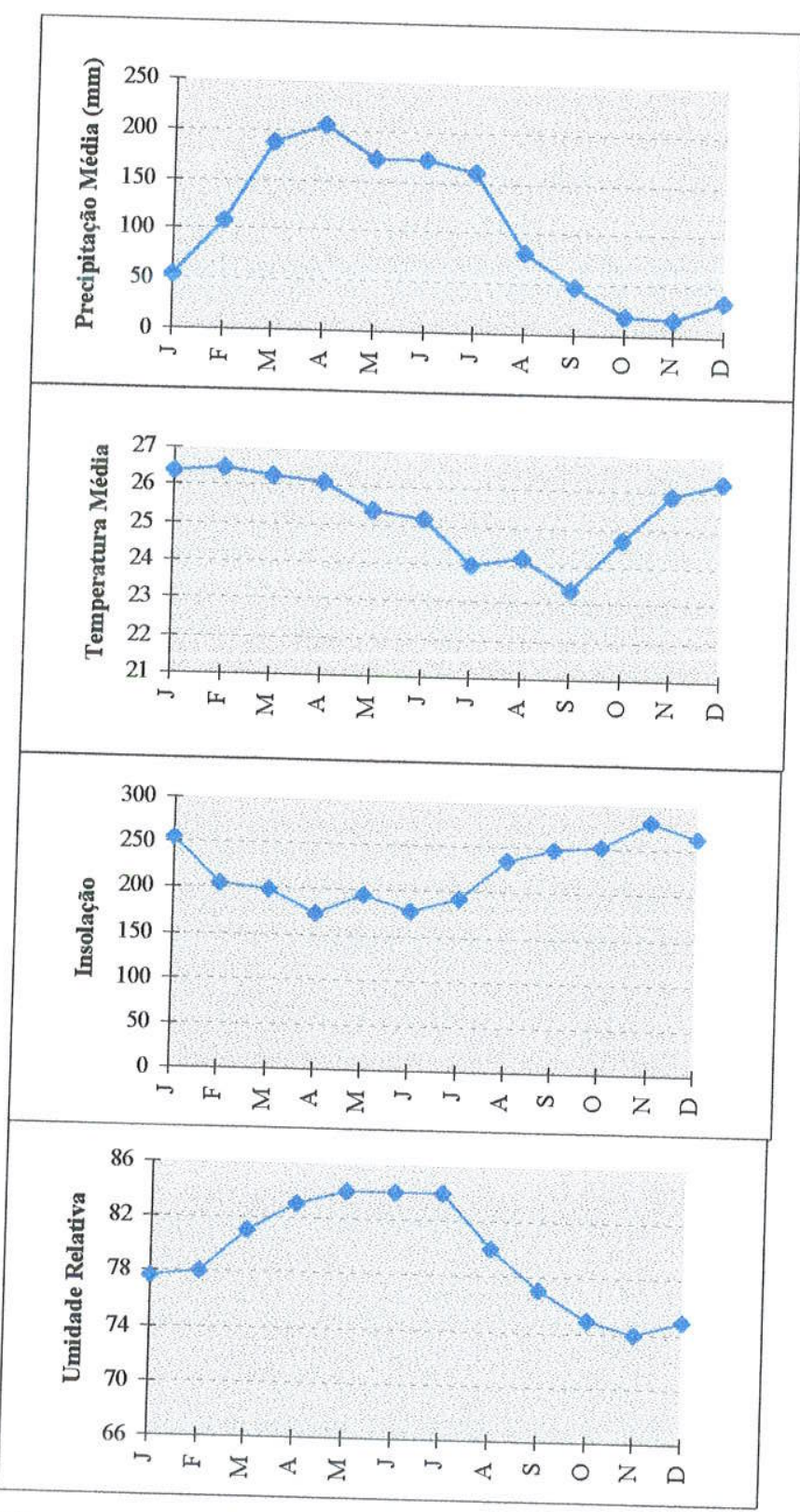

Figura.3.1 - Variação de dados meteorológicos/ média Mensal.

Fonte: (DNMET Posto - Jacumã

Ceará Mirim 1961 - 1990) 


\subsection{3 - Insolação}

Segundo os dados da estação climatológica da Universidade Federal do Rio Grande do Norte, (UFRN), período 1984 a 1993, analisados por MELO (1995), as maiores insolações ocorreram nos últimos meses do ano (periodo seco), atingindo 288 horas (outubro), enquanto os meses menos insolorados compreendem de fevereiro a julho, com valor mínimo de 189 horas. A insolação média anual está compreendida entre 2.591 e 3.189 horas.

$\mathrm{Na}$ estação meteorológica de Jacumã, Ceará Mirim, (médio curso da bacia), a insolação atingiu 279,9 horas/mês com média anual de $2.677,2$ horas.

\section{1 .4 - Evaporação e Evapotranspiração}

VILA NOVA \& REICHARDT (1989) define a evaporação como sendo a taxa de transferência para a atmosfera da fase liquida para a fase vapor, da água contida em um reservatório natural qualquer. A perda de água em cada um desses reservatórios é sempre condicionada pelos elementos de clima, sendo os de atuação direta a radiação solar, a umidade relativa a temperatura do ar e o vento.

OLIVEIRA (1997) caracteriza a evapotranspiração como uma ação conjunta de dois processos: transpiração, quando a água que penetra pelas raízes das plantas é utilizada no processo de fotossíntese, reintegra-se à atmosfera; e evaporação, se a água evaporada pelo terreno nu, próximo às culturas, for evaporada sem ser usada pelas plantas

MELO (1995) calculou a evapotranspiração potencial anual pelo método de TURC (1960), (apud CASTANY, 1975), mediante a aplicação da seguinte equação:

Etp $=0,40(\operatorname{Ig}+50) \times t / t+15 \quad$ onde:

Etp $=$ Evapotranspiração Potencial ( $\mathrm{mm})$

$t=$ Temperatura média mensal no periodo $(1931-1960)$

Ig $=$ Indice Global de Radiação (cal $\left./ \mathrm{cm}^{2} / \mathrm{dia}\right)$

Para o mês de fevereiro foi substituido o valor 0,40 por 0,37 . A tabela.3.1 apresenta os dados de temperatura, índice global de radiação e resultados da evapotranspiração. 
Tabela 3.1-Evapotranspiração potencial no período de 1931-1960

\begin{tabular}{|l|c|c|c|}
\hline \multicolumn{1}{|c|}{ MES } & Ig & T( $\left.{ }^{\circ} \mathbf{C}\right)$ & ETP \\
\hline Janeiro & 500 & 27,2 & 142 \\
\hline Fevereiro & 480 & 27,3 & 127 \\
\hline Março & 470 & 27,3 & 134 \\
\hline Abril & 400 & 26,7 & 115 \\
\hline Maio & 370 & 26,0 & 106 \\
\hline Junho & 370 & 24,9 & 105 \\
\hline Julho & 400 & 24,4 & 112 \\
\hline Agosto & 430 & 24,5 & 119 \\
\hline Setembro & 500 & 25,5 & 138 \\
\hline Outubro & 550 & 26,3 & 153 \\
\hline Novembro & 550 & 26,7 & 154 \\
\hline Dezembro & 510 & 27,0 & 144 \\
\hline Total & & & $1.549 \mathrm{~mm}$ \\
\hline
\end{tabular}

Fonte: (MELO, 1995)

A evapotranspiração total foi da ordem de $1549 \mathrm{~mm}$. O mesmo procedimento foi utilizado para o médio curso da bacia e foi obtido um valor para a evapotranspiração potencial total anual de $1542 \mathrm{~mm}$, conforme está apresentado na tabela 3.2 .

Tabela 3.2- Evapotranspiracão potencial no período de 1961 a 1990

\begin{tabular}{|l|c|c|c|}
\hline \multicolumn{1}{|c|}{ MES } & Ig & T('C) & ETP \\
\hline Janeiro & 500 & 26,4 & 141 \\
\hline Fevereiro & 480 & 26,5 & 136 \\
\hline Marco & 470 & 26,3 & 132 \\
\hline Abril & 400 & 26,1 & 114 \\
\hline Maio & 370 & 25,4 & 105 \\
\hline Junho & 370 & 25,2 & 105 \\
\hline Julho & 400 & 24,0 & 111 \\
\hline Agosto & 430 & 24,2 & 118 \\
\hline Setembro & 500 & 23,4 & 137 \\
\hline Outubro & 550 & 24,7 & 149 \\
\hline Novembro & 550 & 25,9 & 152 \\
\hline Dezembro & 510 & 26,3 & 142 \\
\hline Total & & & $1.542 \mathrm{~mm}$ \\
\hline
\end{tabular}

Fonte: (Estação meteorológica, Posto de Jacumã - Ceará Mirim/RN) 


\subsection{5 - Classificação Climática e Balanço Hídrico}

De acordo com a classificação de KOPPEN, existem cinco zonas diferentes de clima associados a temperatura, a precipitação e ao tipo de vegetação. Dentro desse quadro, a área estudada tem seu clima classificado como sendo do tipo As', tropical chuvoso com verão seco.

Segundo Thornthwaite na classificação climática, o elemento determinante é a evapotranspiração, além da característica pluviométrica e térmica. A avaliação desses parâmetros indica para a área de estudo um clima do tipo seco e subúmido, com pequeno ou nenhum excesso de água, megatérmico com baixa variação estacional.

A concepção de TORNTHWAITE \& MATHER (1955), (apud CASTRO, 1994), para um balanço hídrico de uma determinada área (em um dado volume de controle) fundamentou-se na diferença entre o ganho (precipitação) e o consumo (escoamento superficial e profundo, evaporação ou evapotranspiração).

Aplicando-se essa metodologia para a bacia estudada, com dados do posto de Jacumã e Ceará Mirim, no período de 1961 a 1990, pode-se avaliar as disponibilidades de água no solo. A tabela 3.3, mostra que o primeiro mês do ano inicia com um déficit de $87,1 \mathrm{~mm}$, havendo em seguida infiltração de água no solo até a saturação com excedente de $2301 \mathrm{~mm}$. A partir do mês de agosto há uma retirada de água no solo atingindo outro déficit, o que resulta em um déficit anual de $611,0 \mathrm{~mm}$. A figura 3.2 representa o respectivo balanço hídrico.

Das precipitações ocorridas, parte se escoa, parte é evaporada e outra parcela se infiltra no solo. A parcela que se infiltra corresponde ao excesso de água do solo, que foi avaliada em $231,0 \mathrm{~mm}$ equivalente a uma taxa de infiltração de $18 \%$.

Tabela 3.3 - Balanço hídrico segundo Thornthwaite

\begin{tabular}{|c|c|c|c|c|c|c|c|c|c|c|c|c|c|}
\hline & $J$ & $F$ & $\mathbf{M}$ & $\mathbf{A}$ & $\mathbf{M}$ & $J$ & $J$ & $\mathbf{A}$ & $S$ & 0 & $\mathbf{N}$ & D & Totais \\
\hline $\mathbf{P}$ & 53,9 & 109,4 & 187,8 & 204,5 & 172,2 & 173,3 & 160,0 & 80,5 & 48,8 & 18,7 & 17,5 & 34,5 & $1.261,1$ \\
\hline$E T_{p}$ & 141,0 & 136,0 & 132,0 & 114,0 & 105,0 & 105,0 & 111,0 & 118,0 & 137,0 & 149,0 & 152 & 142,0 & 1.542 \\
\hline$P$ - ETp & 87,1 & $-26,6$ & 55,8 & 90,5 & 67,2 & 68,3 & 49,0 & $-37,5$ & $-88,2$ & $-130,3$ & $-134,5$ & $-107,5$ & $-280,9$ \\
\hline ETr & 53,9 & 109,4 & 132,0 & 114,0 & 105,0 & 105,0 & 111,0 & 80,5 & 48,8 & 18,7 & 17,5 & 34,5 & 930,3 \\
\hline VRA & 0,0 & 0,0 & 55,8 & 44,2 & 0,0 & 0,0 & 0,0 & $-37,5$ & $-62,5$ & 0,0 & 0,0 & 0,0 & 0,0 \\
\hline $\mathbf{R A U}$ & 0,0 & 0,0 & 55,8 & 100,0 & 100,0 & 100,0 & 100,0 & 62,5 & 0,0 & 0,0 & 0,0 & 0,0 & 518,3 \\
\hline $\mathrm{EXC}$ & 0,0 & 0,0 & 0,0 & 46,3 & 67,2 & 68,3 & 49,0 & 0,0 & 0,0 & 0,0 & 0,0 & 0,0 & 230,8 \\
\hline DEF & 87,1 & 26,6 & 0,0 & 0,0 & 0,0 & 0,0 & 0,0 & 37,5 & 88,2 & 130,3 & 134,5 & 107,5 & 611,7 \\
\hline ESC & 1,0 & 0,0 & 0,0 & 23,0 & 45,0 & 57,0 & 53,0 & 27,0 & 13,0 & 7,0 & 3,0 & 2,0 & 231,0 \\
\hline P-ETp/ETp & 0,62 & $-0,20$ & 0,42 & 0,79 & 0,64 & 0,65 & 0,44 & $-0,32$ & $-0,64$ & $-0,87$ & $-0,88$ & $-0,76$ & $-1,35$ \\
\hline
\end{tabular}

Fonte: (DNMET Posto Jacumã - Ceará Mirim/RN 1961 a 1990) 


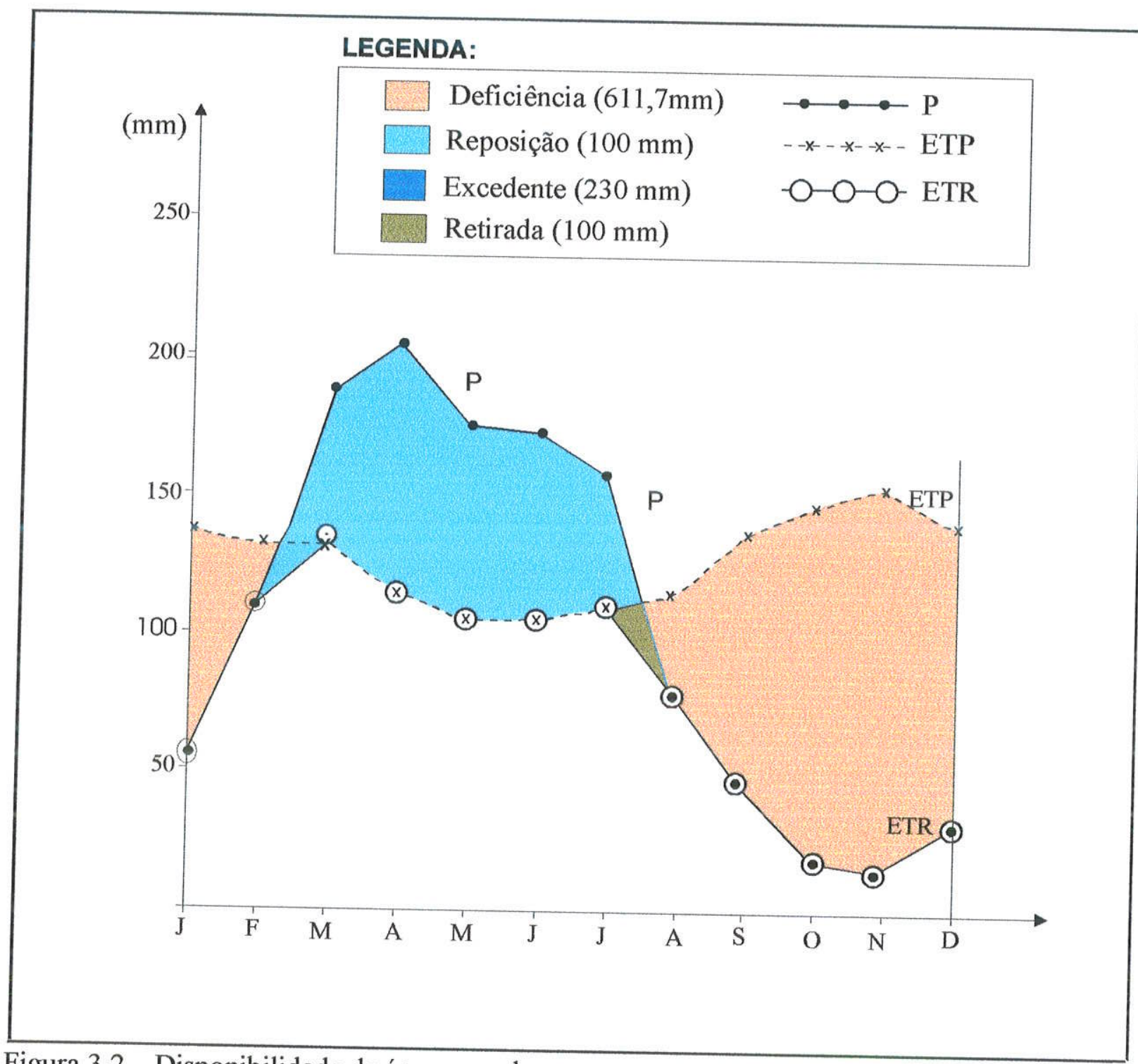

Figura 3.2 - Disponibilidade de água no solo

Fonte (DNMET - Estação meteorológica Jacumã/Ceará Mirim, 1961 a 1990)

\subsection{6 - Geologia}

A Bacia Hidrográfica do Rio Doce compreende os sedimentos tércio-quaternário e quaternário, que repousam sobre rochas précambrianas do embasamento cristalino, (figura 3.3). Esses domínios geológicos tem sido caracterizados e diferenciados em estudos regionais, considerando os critérios litoestratigráficos, estruturais e geocronológicos. 


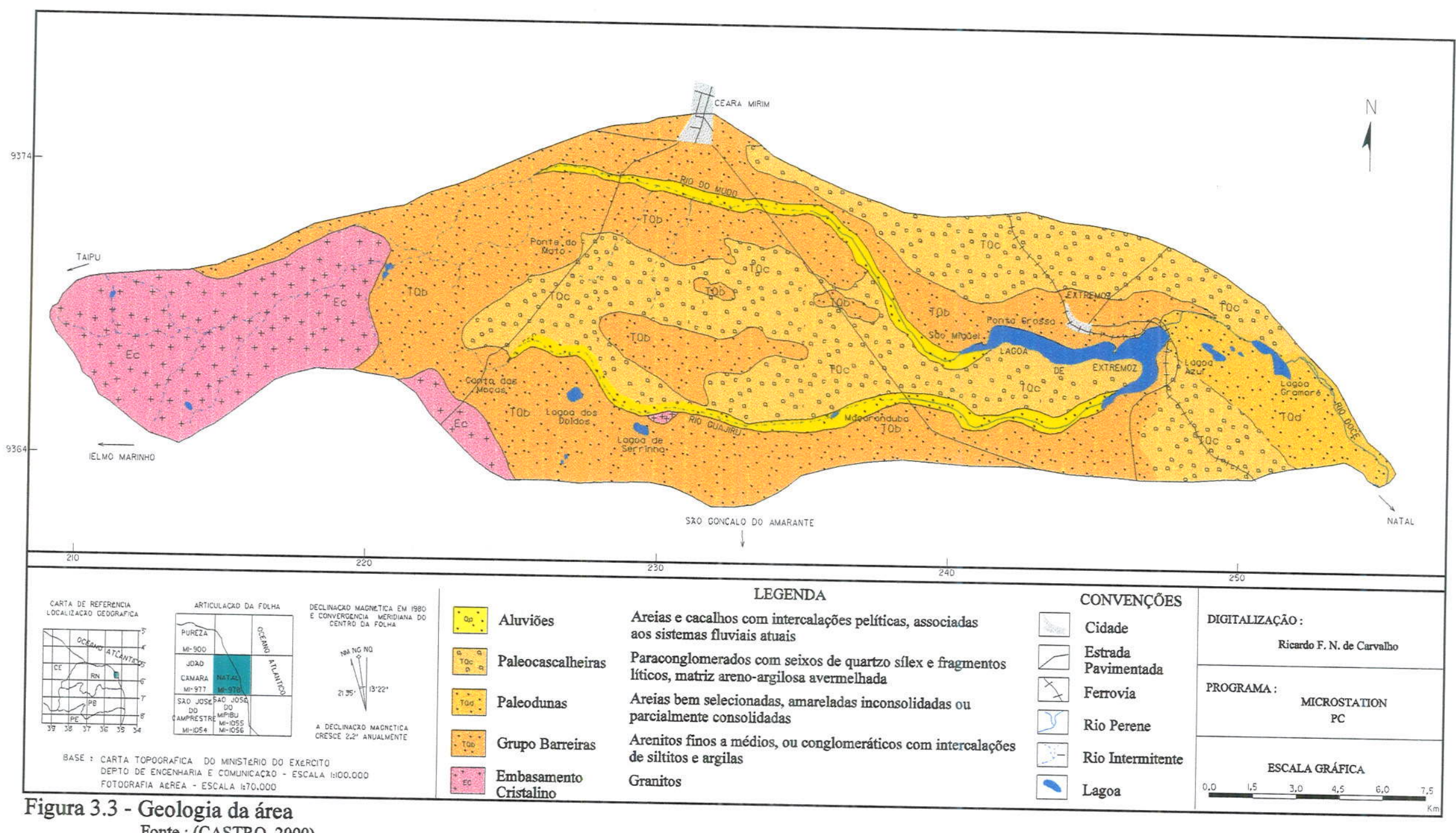




\subsubsection{1 - Embasamento Cristalino}

Cobre aproximadamente $60 \%$ da área geográfica do Estado, equivalente a $31.809 \mathrm{~km}^{2}$ e são agrupados em duas grandes unidades litoestratigráficas: o Grupo Caicó (ou Complexo Caicó), e o Grupo Seridó, (JARDIM DE SÁ, 1984). O Grupo Caicó constitui a unidade mais antiga, Arqueana, compreendendo uma associação de rochas gnáissico-migmatíticas e graníticas. O Grupo Seridó compõe a Faixa Dobrada Seridó, que divide-se em três formações:

- Formação Jucurutu (unidade inferior): constituida por biotita - gnaisses, gnaisses quartzofeldspáticos, intercalações de mármores, calco-silicáticas, quartzitos, micaxistos, metaconglomerados, anfibolitos, formações ferriferas e unidades de ortognaisses;

- Formação Equador (unidade intermediária): representada por quartzitos puros, feldspáticos ou muscovíticos;

- Formação Seridó (unidade superior): constituída por micaxistos, com intercalações de matavulcânicas máficas, mármores, calco-silicáticas e quartzitos.

No âmbito da área estudada, as rochas cristalinas afloram no curso superior da bacia abrangendo os municípios de Taipu e Ielmo Marinho. CRUZ (1983) identificou a sul de Taipu litotipos como micaxistos com níveis quartzíticos, gnaisses anfibolíticos, migmatitos, monzogranitos e granodioritos.

\subsubsection{2-Sedimentos Tércio-Quaternários}

São representados pelos sedimentos da Seqüencia Barreiras, que na classificação de MABESOONE et al. (1977) apresenta as seguintes subdivisões:

- Formação Serra do Martins: compreende a seqüência inferior, com fácies arenosa a conglomerática. Os sedimentos são ferruginosos e silicificados, indicando sedimentos de forte diagênese. A idade varia do final do Oligoceno até o início do Mioceno.

- Formação Guararapes: constitui a unidade intermediária e predominam os sedimentos arenosos de cores variegadas, fácies argilosas e níveis de seixos de quartzo. Encontra-se coberta por um nível arenoso e síltico-argiloso, denominado de intemperismo Riacho Morno. Sua ocorrência é relevante na faixa costeira leste do Estado. Na área de estudo ocorre no baixo curso da Bacia. 
- Formação Macaíba : constitui a unidade superior, sendo formada de sedimentos arenoargilosos e argilo-arenosos, com seixos na base, coloração esbranquiçada e são capeados por sedimentos denominados de Intemperismo Potengi, formados por areias argilosas, vermelhas, amareladas e creme.

Estudos posteriores (MABESOONE, 1991a) constatou que a seqüência sedimentar, "Grupo Barreiras" deveria consistir de uma formação, passando a ser denominada de Formação Barreiras. $\mathrm{Na}$ área estudada essa Formação consiste na unidade litoestratigráfica de maior representatividade, aflorando em $90 \%$ da área.

\subsubsection{3 - Sedimentos Quaternários}

Os sedimentos de idade quaternária incluem as dunas, depósitos praiais, e aluviões. - Dunas - são areias bem selecionadas, com granulometria variando de fina a média e que sofrem ação dos ventos tomando suas formas caracteristicas ao longo da faixa costeira, com tonalidades esbranquiçadas, amarelas, cinzas e avermelhadas. COSTA (1970) fez a seguinte subdivisão:

Pleistoceno Inferior - compreende as dunas retrabalhadas pela erosão, ou fixadas por vegetação, de coloração avermelhada e com cotas altimétricas entre 40 e $60 \mathrm{~m}$ e geralmente são de tonalidades avermelhadas.

Idade Intermediária - relacionamse as areias de coloração amarelada, com altitudes variando entre 80 e 120 metros e são recobertas por vegetação.

Pleistoceno Superior - refere-se aos sedimentos que ocupam praias e baixadas e constitui-se por areias nas tonalidades amarelas e esbranquiçadas.

$\mathrm{Na}$ porção leste da área ocorrem as dunas fixas, sob formas de cordões alongados, são esbranquiçadas a amareladas em cotas de 30 a 40 metros.

- Depósitos Praiais - são representados por areias com granulometria que varia de fina a média com predominância dos grãos grosseiros. Nas praias são encontrados, formando faixas paralelas à costa, sob formas de recifes de arenito, apresentando textura fina a média. $\mathrm{Na}$ área estudada estes sedimentos ocorrem na praia da Redinha. 
- Aluviões: caracterizam os depósitos fluviais, lacustre e estuarino e são formados por areias quartzosas finas e grosseiras, mal selecionadas, com seixos de quartzo arredondados e subarredondados. Em alguns locais apresentam-se com matéria orgânica, turfa e argila orgânica.

\section{2 - Aspectos Sócio-Econômicos}

A área de estudo abrange parcialmente seis municípios: Ceará Mirim, Extremoz São Gonçalo do Amarante, Natal, Ielmo Marinho e Taipu, (figura 3.4). Com base nos dados oficiais do censo demográfico do IBGE (1996), foi estimada uma população de 126.519,00 habitantes e uma densidade demográfica de $374,32 \mathrm{hab} . / \mathrm{km}^{2}$.

No curso inferior da bacia, especificamente nos municípios de Extremoz e São Gonçalo do Amarante está instalado um dos pólos industriais do Estado com indústrias de grande porte como a Antártica, Parmalat, Vicunha, Coats, Guararapes Têxtil entre outras. O processo de industrialização foi intensificado na década de noventa, com o incentivo do governo do estado, encontrando-se atualmente em fase de crescimento e com perspectivas de instalação de novas unidades industriais. O turismo é outra atividade relevante na bacia. De acordo com o anuário estatístico de 1996, entre os anos de 1991 a 1995, houve um crescimento no fluxo de turistas de $60 \%$.

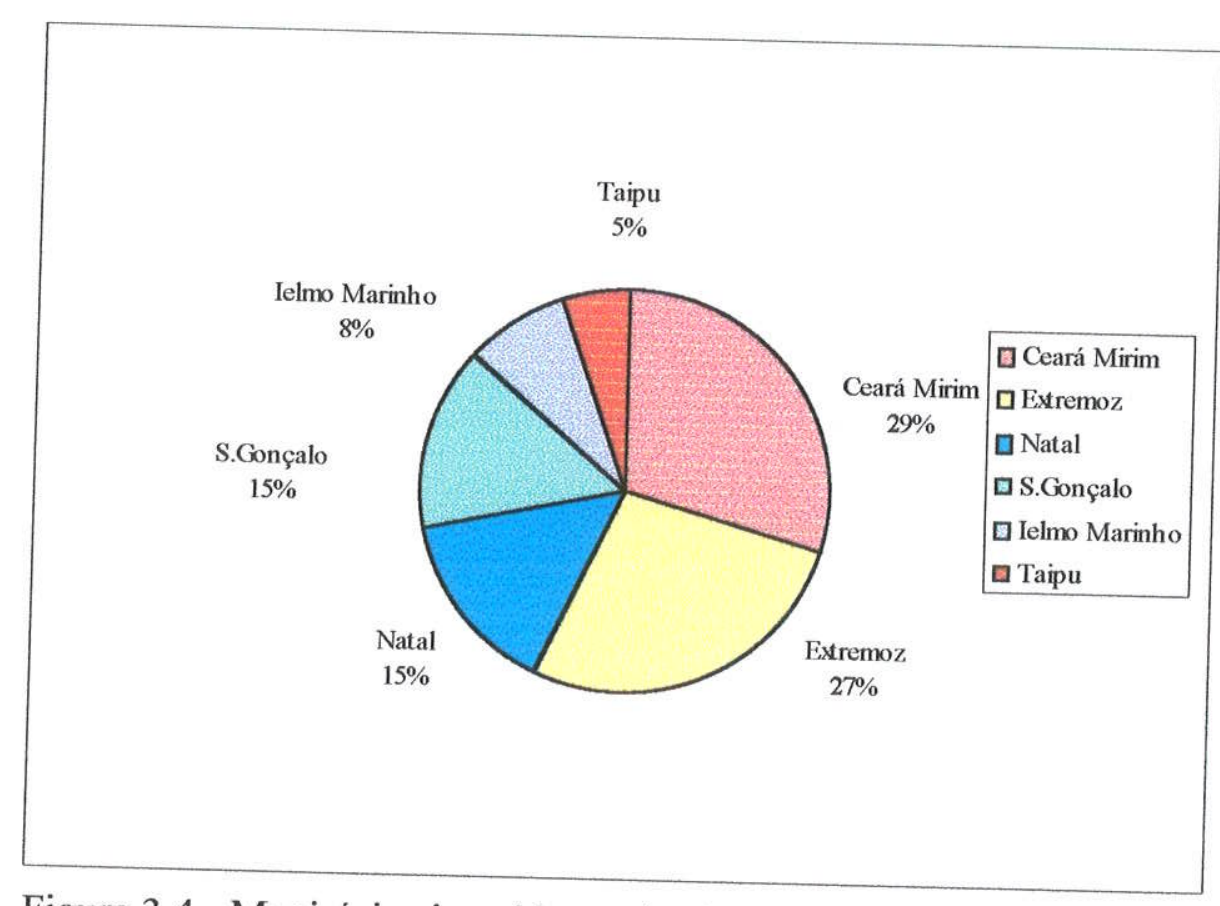

Figura 3.4 - Municípios inseridos na bacia do rio Doce.

Fonte: (CASTRO, 2000) 
O número de estabelecimentos de ensino compreende 30 escolas destinadas ao ensino pré escolar, 40 para o ensino de primeiro grau e 6 para o segundo grau. Para os estabelecimentos de saúde foram estimados um total de 21 postos de saúde em toda a bacia.

$\mathrm{Na}$ agricultura, a banana constitui-se o principal produto (13\%), seguido da produção de coco-da-bahia $9 \%$, milho $(8 \%)$, mandioca $(7 \%)$, abacate $(6 \%)$ e outros como manga, feijão, batata e cana de açúcar.

Na pecuária, destaca-se a bovinocultura ( 7.473 cabeças), dirigida principalmente à produção de leite. Os demais rebanhos são inexpressivos em termos de efetivos e valor de produção.

\subsection{1 - Recorte para a cidade de Extremoz}

O município de Extremoz compreende uma área de $135,3 \mathrm{~km}^{2}(0,25 \%$ do Estado), uma população de 14.941 habitantes e uma densidade demográfica de $110,4 \mathrm{hab} / \mathrm{km}^{2}$, considerada alta quando comparada aos outros municípios da região.

A taxa de urbanização, de $54,7 \%$ expressa uma significativa parcela de população alojada nas áreas nurais $(45,3 \%)$. Extremoz tem 4,78 habitantes por domicílio, sendo pequena a diferença de tal relação entre a área urbana $(4,73)$ e a área rural $(4,84)$, Secretaria de Recursos Hídricos do Estado do Rio Grande do Norte, Secretaria de Recursos Hídricos do Estado do Rio Grande do Norte (SERHID, 1998a).

\subsubsection{1 - Infra-Estrutura Social}

O município de Extremoz tem cerca de $67,6 \%$ dos domicílios sem abastecimento de água adequado ou sem canalização interna. Os domicílios com canalização interna e ligados à rede geral, representam $29 \%$, e os domicílios sem canalização interna, mas com abastecimento de rede geral $36,3 \%$. O uso de poço ou nascente para abastecimento, no entanto sem canalização interna, correspondem a $16,2 \%$ (IBGE, 1996).

\subsubsection{2 - Condições Sanitárias}


Os domicílios que fazem uso da fossa séptica representam $88 \%$, porém, sem sumidouro, enquanto a fossa negra compreende $10,8 \%$ dos domicilios.

O percentual de domićlios servidos pela coleta de lixo é de $19,8 \%$. Os que têm o lixo queimado ou enterrado correspondem a $53,7 \%$ e aqueles cujo lixo é jogado representa $26,1 \%$, e outras formas $0,4 \%$.

\subsubsection{3 - Qualidade de Vida}

Os indicadores de pobreza são expressivos no município de Extremoz, sem no entanto, alcançar situações mais alarmantes como as encontradas em outras bacias. São 2.046 (49\%) as familias indigentes no município de Extremoz, enquanto o percentual do Estado é $46 \%$. O total de 1.674 crianças indigentes de 0 a 6 anos corresponde a 58,5\%, também acima da média estadual de $49,3 \%$. As crianças desnutridas de 0 a 5 anos somam 1.005 (36,3\%), abaixo da média do Estado (41,1\%). O percentual de crianças de 0 a 6 anos em domicílio urbano com abastecimento de água inadequado é de $57 \%$, superior a média estadual que é de $41,2 \%$, (SERHID, 1998 a).

\section{0 - O SISTEMA HÍDRICO SUBTERRÂNEO E A LAGOA DE EXTREMOZ}

O comportamento do sistema hídrico subterrâneo foi caracterizado a partir da análise das propriedades litológicas, dimensionais, hidráulicas e hidrodinâmicas, associada aos estudos realizados na região litoral oriental do Rio Grande do Norte, como: TAHAL/SONDOTÉCNICA (1969); MANOEL FILHO (1970), IPT (1982); CASTRO (1994), MELO (1995); COSTA (1997); SERHID (1998a); MELO \& FEITOSA (1998), TOSTES (1999) e DINIZ FILHO (1999). Na área estudada os principais mananciais de águas subterrâneas contemplam os sistemas aqüíferos: Cristalino, Jandaira, Barreiras e Aluvial.

\section{1 - Aqüúfero Cristalino}

No Estado do Rio Grande do Norte, o aqüífero Cristalino constitui-se por rochas PréCambrianas, caracterizando uma área de ocorrência superior a área total dos meios aqüiferos 
porosos, ocupando cerca de $60 \%\left(31.000 \mathrm{Km}^{2}\right)$ da superficie estadual. Na área estudada o aqüífero cristalino ocorre aflorando no curso superior da bacia.

Em função das baixas condições de permo-porosidade e consequentemente baixa capacidade de armazenamento e circulação das águas subterrâneas, constitui um meio aqüifero de baixo potencial hidrogeológico. Diante destas características as águas são limitadas em quantidade e qualidade, cujas vazões são da ordem de $3,0 \mathrm{~m}^{3} / \mathrm{h}$ e teores de Sólidos Totais Dissolvidos em torno de $2.000 \mathrm{mg} / \mathrm{L}$.

A recarga do sistema aqüifero cristalino se processa através da infiltração e acumulação de águas de chuva nas fraturas e/ou falhas existentes. Considerando que os terrenos cristalinos são impermeáveis gerando rápido escoamento superficial, a hipótese mais provável é que as coberturas (aluviões, regolitos e/ou coluviões), funcionem como elemento regulador que receptam, armazenam e transmitam águas de chuva às fissuras subjacentes.

\section{2 - Aqüífero Jandaíra}

$\mathrm{Na}$ área em questão o aqüífero Jandaíra ocorre predominantemente em subsuperfície, no médio curso da bacia, compreendendo os municípios de São Gonçalo do Amarante e Ceará Mirim. Neste trecho a profundidade dos poços variam entre 60 a 120 metros e em alguns locais, o aqüífero Barreiras apresenta pequenas espessuras (5 a 15 metros), de forma que devido às variações climáticas sazonais, o posicionamento dos níveis das águas subterrâneas fíca abaixo do topo do aqüífero Jandaíra, no período de estiagem, caracterizando uma insaturação do aqüifero Barreiras.

Estudos realizados por DINIZ FILHO (1999), na bacia Ceará Mirim, ao norte da bacia estudada, constataram que o aqüífero Jandaíra se comporta em geral como um aqüífero livre, formando um sistema único com o aqüífero Barreiras (sobrejacente) em grande parte da área, tendo em vista não ter sido observadas diferenças significativas de cargas hidráulicas entre os dois sistemas. Portanto, pode ocorrer semi-confinamentos locais através das camadas argilosas situadas na transição do topo da Formação Jandaira para a base dos sedimentos Barreiras. Foi verificado que a recarga nos calcários se processa por infiltração vertical descendente das águas provenientes do aqüífero Barreiras sobreposto. A tabela 4.1 resume os parâmetros hidrodinâmicos, regionais do aqüífero Jandaíra. 
Tabela 4.1 - Parâmetros hidrodinâmicos regionais do aqüífero Jandaíra

\begin{tabular}{|l|l|l|l|l|}
\hline FONTE & Ano & $\mathrm{T}\left(\mathrm{m}^{2} / \mathrm{s}\right)$ & $\mathrm{K}(\mathrm{m} / \mathrm{s})$ & Sy $(\%)$ \\
\hline Manoel Filho & 1970 & $2,4 \times 10^{-2}$ & $1,10 \times 10^{-4}$ & 5 \\
\hline IPT & 1982 & $1,56 \times 10^{-3}$ & $8,21 \times 10^{-6}$ & 5 \\
\hline Mistretta & 1984 & $3,15 \times 10^{-3}$ & $3,6 \times 10^{-2}$ & 5 \\
\hline SERHD & $1998^{\mathrm{a}}$ & $3,05 \times 10^{-3}$ & $7,9 \times 10^{-5}$ & \\
\hline Valor Médio & & $7,9 \times 10^{-3}$ & $6,6 \times 10^{-5}$ & 5 \\
\hline
\end{tabular}

Fonte: (DINIZ FILHO, 1999)

\section{3 - Aqüífero Barreiras}

\subsection{1 - Evolução do Conhecimento do Aqüífero Barreiras}

Nas décadas de 70 a 80 , foram efetuados estudos que contemplaram a hidrogeologia de Natal, como: CONTEGE (1970), COSTA (1970), IPT (1982), PLANAT (1983), ACQUAPLAN (1988), além de outros de caráter localizado que trataram principalmente da questão da produtividade dos poços das captações de abastecimento público. Todos estes trabalhos consideram a existência de duas unidades aqǘferas, uma superior do tipo livre, formada de sedimentos dunares, com baixo potencial hidrogeológico e uma inferior, semiconfinada constituída por sedimentos do Grupo Barreiras, separadas por uma camada areno-argilosa com características de aquitard.

CASTRO (1994) quando desenvolveu estudos sobre a qualidade das águas subteriâneas no bairro de Cidade Nova em Natal, verificou que os níveis d'água relativos ao período observado, posicionavam-se no domínio das camadas argilosas e com a presença dos prolongados periodos de estiagem. Estes níveis tenderam a ficar muito abaixo destas camadas, devido as perdas d'água pelo fluxo subterrâneo natural e pela explotação dos poços. Também foi verificado que nos anos de precipitações elevadas, o nivel das águas subterrâneas subiram e atingiram os pacotes de areias das formações dunares. Em ambos os casos, constatou-se a tendência de mudança no comportamento do aqüífero semiconfinado para livre.

MELO (1995) realizou estudos com a finalidade de conhecer o processo de contaminação das águas subterrâneas de Natal e dentro do contexto da pesquisa, apresentou um 
modelo hidrogeológico conceitual que define um sistema hidráulico único, complexo e indiferenciado, denominado de Sistema Aqüífero Dunas/Barreiras.

A análise das seções hidrogeológicas no curso inferior da bacia, indica que as cargas hidráulicas dos poços rasos e profundos se ajustam a uma mesma superficie potenciométrica, conforme pode ser visualizado nas figuras 4.1 e 4.2. Este comportamento associado ao caráter lito-estrutural dos estratos sedimentares, sugere que as formações dunares e os sedimentos Barreiras formam um sistema hidráulico único, podendo localmente apresentar semiconfinamentos, tal como ocorre na zona sul de Natal (MELO, 1995 e MELO, 1998).

\subsection{2 - O Sistema Aqüífero Dunas/Barreiras na Bacia do Rio Doce}

O sistema aqüifero Dunas/Barreiras constitui o maior potencial hídrico da bacia do Rio Doce, especificamente no seu curso inferior. Compreende arenitos de textura variada, apresentando níveis finos a grosseiros, algumas vezes com cascalho e seixos. As intercalações argilosas ocorrem com freqüência, contribuindo para uma maior complexidade do sistema hidrogeológico.

A parte superior do sistema aqüifero Dunas/Barreiras é representado por sedimentos heterogêneos, formados por argilas arenosas e arenitos argilosos. Freqüentemente ocorrem mudanças laterais de fácies com passagens bruscas de argilas para arenitos argilosos. Na parte inferior, o aqüífero Barreiras está limitado por arenitos carbonáticos, (figura 4.1).

No município de Taipu, na nascente do Rio do Mudo, essas coberturas tendem a diminuírem, com espessuras médias de 6 metros e os raros poços existentes, possuem profundidades de no máximo 50 metros nos terrenos cristalinos, (seção hidrogeológica W-Z), (figura, 4.2).

Os perfis dos poços do Distrito Industrial de Extremoz, e do sistema de abastecimento público da captação Gramoré da zona norte da cidade, apresentam espessuras de sedimento que variam de 29 metros, (Vila Socorro) a 90 metros (CDI) com média de 66,5 metros. A análise dos perfis litológicos dos poços tubulares, indicou as freqüentes intercalações de argilas, e em função disso, foram avaliadas as espessuras saturadas com a presença dessas intercalações e com a ausência das mesmas, as espessuras saturadas efetivas. 


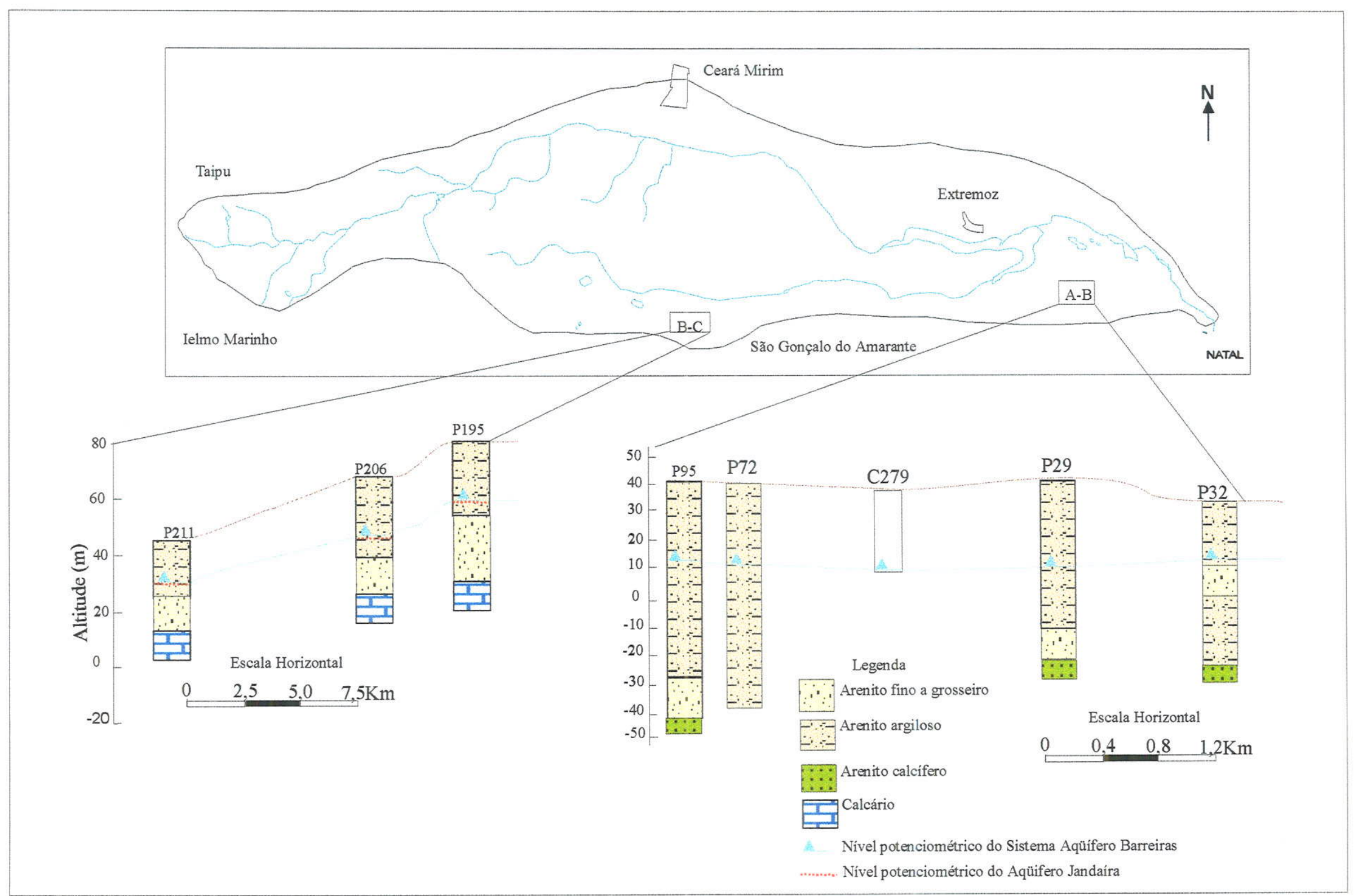

Figura 4.1 - Seções hidrogeológicas $\mathrm{AB}$ e BC

Fonte:(CASTRO, 2000) 


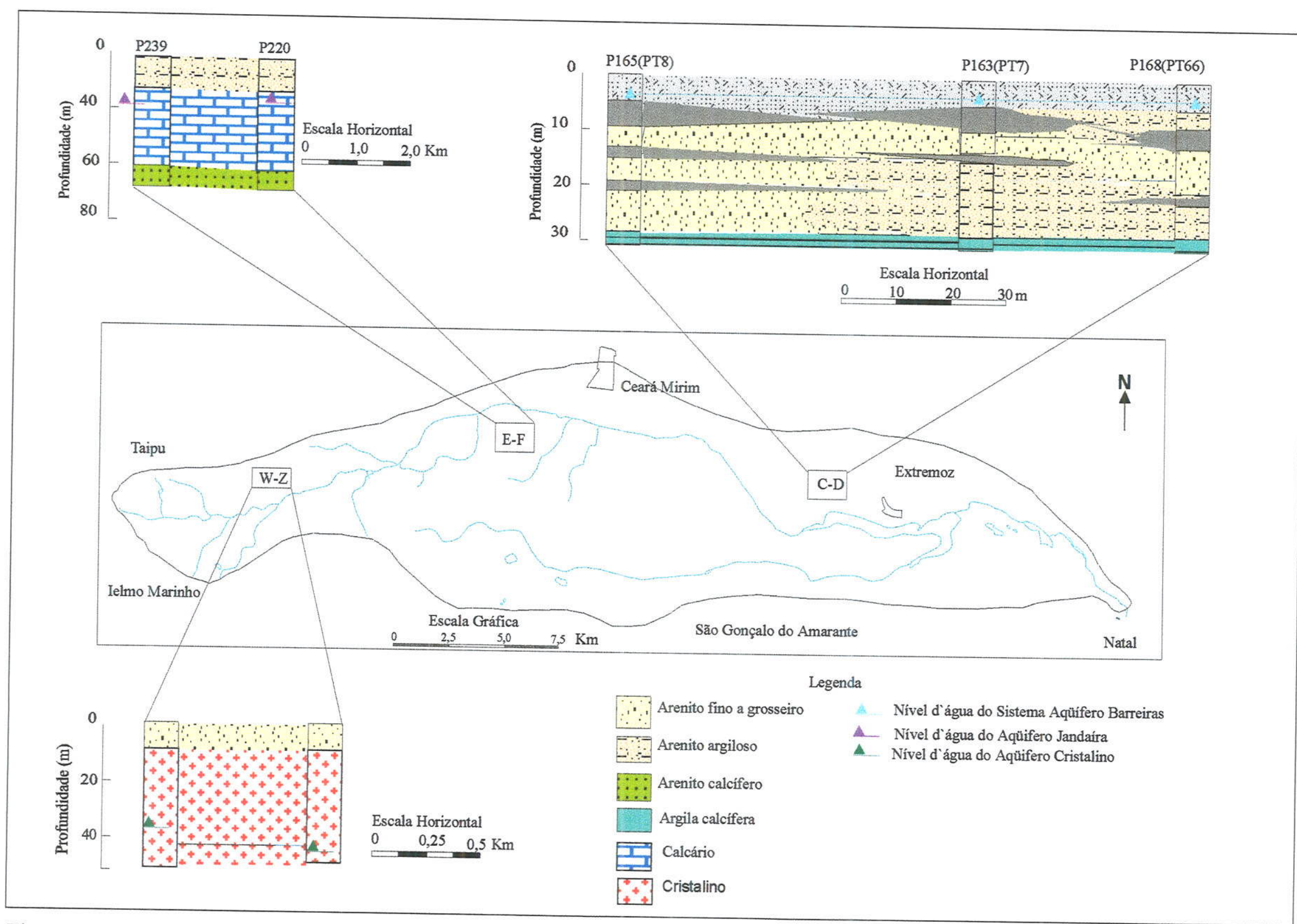

Figura 4.2 - Seções hidrogeológicas CD, EF e WZ Fonte: (CASTRO, 2000) 
As espessuras saturadas, variam entre 29,0 a 76,5 metros com média de 46,0 metros e as espessuras saturadas efetivas variam de 16,9 a 57 metros com média de 38,3 metros.

O sistema aqüifero Dunas/Barreiras apresenta maiores espessuras saturadas no curso inferior da bacia, e diminui em direção ao médio curso. A montante nas localidades de Ponte do Mato e Canto de Moça as espessuras saturadas são da ordem de 10 a 14 metros, cujas captações são principalmente através de poços amazonas, cujas profundidades não ultrapassam aos 14 metros. A tabela 4.2 apresenta o resumo dos parâmetros dimensionais do sistema aqüifero Dunas/Barreiras.

Tabela - 4.2 - Parâmetros dimensionais do sistema aqüifero Dunas/Barreiras

\begin{tabular}{|c|c|c|c|c|c|c|}
\hline Poço & Localização & $\begin{array}{c}\text { Nível } \\
\text { Estático } \\
\text { (m) }\end{array}$ & Data & $\begin{array}{c}\text { Espessura } \\
\text { Sedimento } \\
\text { (m) }\end{array}$ & $\begin{array}{c}\text { Espessura } \\
\text { Saturada } \\
(\mathrm{m})\end{array}$ & $\begin{array}{c}\text { Espessura } \\
\text { Saturada } \\
\text { Efetiva (m) } \\
\end{array}$ \\
\hline $\mathrm{P} 22$ & Contendas III & 1,50 & - & 69,0 & 67,50 & 55,50 \\
\hline $\mathrm{P} 24(\mathrm{PT} 1)$ & Conjunto Gramoré & 7,94 & $04 / 87$ & 52,0 & 41,06 & 41,06 \\
\hline $\mathrm{P} 25$ (PT6) & Conjunto Gramoré & 15,80 & $11 / 90$ & 57,0 & 41,20 & 41,20 \\
\hline $\mathrm{P} 26$ (PT7) & Conjunto Gramoré & 29.20 & $12 / 90$ & 64,0 & 34,80 & 30,50 \\
\hline P27 (PT9) & Conjunto Gramoré & 13,65 & $10 / 90$ & 56,0 & 42,35 & 38,35 \\
\hline P28(PT5) & Conjunto Gramoré & 32,00 & $10 / 90$ & 73,0 & 41,00 & 41,00 \\
\hline P29 (PT3) & Conjunto Gramoré & 18,44 & $08 / 88$ & 65,0 & 46,56 & 46,56 \\
\hline P30 (PT8) & Conjunto Gramoré & 28,15 & $06 / 90$ & 63,0 & 34,85 & 28,85 \\
\hline $\mathrm{P} 31(\mathrm{PT} 10)$ & Conjunto Gramoré & 15,19 & $11 / 90$ & 57,0 & 41,81 & 33,81 \\
\hline P32 (PT2) & Conjunto Gramoré & 5,78 & - & 58,0 & 52,22 & 50,22 \\
\hline P52 & Passagem da Vila & - & - & 58,0 & 24,00 & 23,00 \\
\hline $\mathrm{P} 53(\mathrm{P} 6)$ & Vicunha & 18,90 & $09 / 97$ & 75,0 & 56,10 & 56,10 \\
\hline P56 (P5) & Vicunha & 23,49 & $09 / 95$ & 81,0 & 57,00 & 57,00 \\
\hline P59 (P1) & Vicunha & 18,13 & $01 / 91$ & 74,0 & 56,00 & 38,00 \\
\hline $\mathrm{P} 68(\mathrm{P} 2)$ & Vicunha & 16,58 & $09 / 94$ & 56,0 & 39,00 & 36,00 \\
\hline $\mathrm{P} 70(\mathrm{P} 4)$ & Guararapes Têxtil & 23,85 & $09 / 97$ & 81,0 & 57,15 & 47,15 \\
\hline P72(P5) & Guararapes Têxtil & 23,88 & $09 / 97$ & 81,0 & 57,12 & 54,12 \\
\hline $\mathrm{P} 76(\mathrm{P} 6)$ & Guararapes Têxtil & 25,30 & $09 / 97$ & 85,0 & 59,70 & 54,70 \\
\hline P81 & Mastex & 30,20 & $05 / 94$ & 80,0 & 49,80 & 42,00 \\
\hline P87 & Henfibra & 25,75 & $08 / 92$ & 61,0 & 35,00 & 34,00 \\
\hline P93 & Estrela do Mar & 31,50 & $06 / 81$ & 74,0 & 43,00 & 20,50 \\
\hline P98 & Vila de Fátima & 4,60 & $07 / 91$ & 34,0 & 29,00 & 21,00 \\
\hline $\mathrm{Pl01}$ & Parmalat & 27,20 & $09 / 97$ & 82,0 & 54,80 & 28,00 \\
\hline $\mathrm{PlO3}$ & Coats & 32,04 & 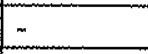 & 90,0 & 57,96 & 40,96 \\
\hline $\mathrm{P} 109$ & CDI & 33,65 & $09 / 97$ & 86,0 & 52.35 & 39.35 \\
\hline $\mathrm{P} 120$ & Extremoz - Sede & 34,50 & $09 / 97$ & 62.0 & 27,50 & 21,00 \\
\hline $\mathrm{Pl} 45$ & Granja São José & 18,45 & $11 / 90$ & 95,0 & 76,55 & 55,55 \\
\hline $\mathrm{P} 163$ & Lagoa Extremoz & Surgente & $10 / 88$ & 29,0 & 29.00 & 16,90 \\
\hline $\mathrm{Pl} 65$ & Lagoa Extremoz & Surgente & $10 / 88$ & 30,0 & 30,00 & 18,50 \\
\hline \multicolumn{4}{|c|}{ VALORES MÉDIOS } & 66,5 & 46,0 & 38,3 \\
\hline
\end{tabular}

Fonte: (CASTRO, 2000) 


\subsection{3 - Fluxo Subterrâneo}

As curvas potenciométricas foram obtidas com base em dados de medições das profundidades do nivel das águas no periodo de setembro/97. O mapa potenciométrico foi elaborado especificamente para o sistema aqüífero Dunas/Barreiras, no curso inferior da bacia, cujos poços tubulares cadastrados captam águas, exclusivamente deste manancial subterrâneo.

A configuração das equipotenciais, (figura 4.3), indica duas frentes de fluxo, uma ao norte da área, com fluxo convergente para o rio do Mudo, lagoa de Extremoz e rio Doce, com gradientes da ordem de $0,97 \%$ e uma frente ao sul da área com fluxo direcionado para o rio Guajiru, lagoa de Extremoz e rio Doce, com gradientes de $0,8 \%$. A vazão de fluxo subterrâneo em cada setor foi estimada a partir da lei de Darcy de acordo com a equação:

$$
Q=\text { K.B.I.L }
$$

onde:

$Q=$ descarga do fluxo subterrâneo $\left(\mathrm{m}^{3} / \mathrm{s}\right.$ ou $\left.\mathrm{m}^{3} / \mathrm{ano}\right)$;

$\mathrm{K}=$ condutividade hidráulica $(\mathrm{m} / \mathrm{s})$;

$B=$ espessura saturada $(m)$;

$I=$ gradiente hidráulico $(\%)$;

$\mathrm{L}=$ largura da frente de escoamento $(\mathrm{m})$.

Para a avaliação da estimativa do fluxo subterrâneo foram adotados os valores médios da espessura saturada efetiva relacionada as informações dos perfis litológicos dos poços tubulares nos referidos setores. Os valores das condutividades hidráulicas aplicados foram a partir de avaliações hidráulicas efetuadas no âmbito deste trabalho, e resultados obtidos por TOSTES (1998), no setor norte. No setor sul/sudeste da área, foram utilizados valores dos parâmetros hidráulicos obtidos por MELO (1998). De acordo com a aplicação da equação, a descarga estimada para o setor norte segundo uma frente de escoamento de $20 \mathrm{~km}$ foi de $42,0 \mathrm{x}$ $10^{6} \mathrm{~m} 3 / \mathrm{ano}$. No setor sul, considerando uma frente de escoamento de $16 \mathrm{~km}$ foi estimada uma descarga da ordem de $34,0 \times 10^{6} \mathrm{~m}^{3} /$ ano. A vazão total do fluxo subterrâneo natural ficou estimada em $76,0 \times 10^{6} \mathrm{~m}^{3} /$ ano, tabela 4.3 . 


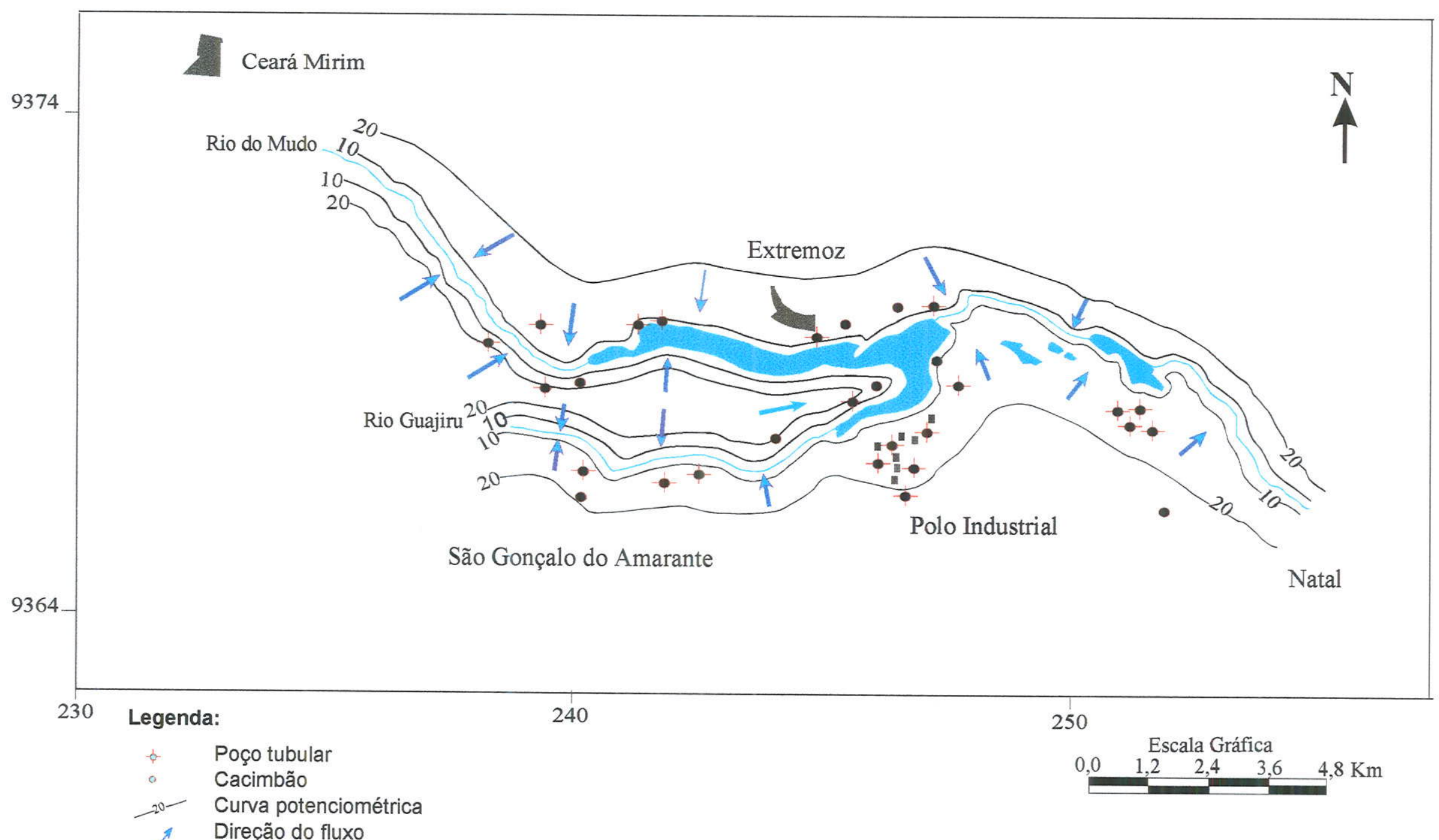

Figura 4.3 - Potenciometria do Sistema Aqǘfero Dunas/Barreiras no curso inferior da Bacia do Rio Doce Fonte: (CASTRO, 2000) 
Tabela 4.3 - Descargas do fluxo subterrâneo do aqüífero Barreiras - curso inferior da Bacia do Rio Doce

\begin{tabular}{|l|l|l|l|l|l|}
\hline Setor & $\mathrm{K}(\mathrm{m} / \mathrm{s})$ & $\mathrm{b}(\mathrm{m})$ & $\mathrm{I}(\%)$ & $\mathrm{L}(\mathrm{Km})$ & $\mathrm{Q}\left(\mathrm{m}^{3} / \mathrm{ano}\right)$ \\
\hline Frente Rio Doce Norte/Nordeste & $2,0 \times 10^{-4}$ & 34 & 0,97 & 20 & $42 \times 10^{6}$ \\
\hline Frente Rio Doce Sul/Sudeste & $2,2 \times 10^{-1}$ & 38 & 0,80 & 16 & $34 \times 10^{6}$ \\
\hline & Total & & & $76 \times 10^{6}$ \\
\hline
\end{tabular}

\subsection{4 - Estimativa das Reservas e Recursos Explotáveis}

Segundo os registros geológicos citados por REBOUÇAS (1997), indicam que o volume total da terra $\left(1,4\right.$ bilhão $\left.\mathrm{km}^{3}\right)$ tem permanecido constante durante o último milhão de anos e nada indica que possa se alterar durante o próximo milhão de anos. No entanto, o volume de água estocado nos reservatórios pode variar, como ocorreu durante o último período glacial que durou 100.000 e 10.000 anos.

Os volumes de água naturalmente estocados representam as reservas, tradicionalmente classificadas como renováveis e não renováveis. REBOUÇAS (1997) comenta sobre tal classificação e considera-a de certa forma errônea, já que não existe água subterrânea desconectada do ciclo hidrológico. Na maioria dos casos, os tempos de residência das águas nos aqüiferos são da ordem de dezenas de anos, em alguns casos atinge-se a escala de centenas e até de milhares de anos. De forma que, as taxas de renovabilidade natural poderão ser muito baixas, tornando as reservas praticamente não renováveis na escala de vida útil dos projetos de utilização. Um aqüifero com grandes volumes estocados poderá apresentar águas muito velhas, na medida que, estando muito saturado, não existe volume disponivel para receber novas recargas. Apresentam este tipo de comportamento os aqüíferos livres e confinados localizados em regiões hidroclimáticas com grandes excedentes de água para recarga, como é o caso do Paraná, Maranhão, Recôncavo Baiano e Faixa Costeira Leste. Dessa forma, os processos de extração poderão induzir recargas, na medida em que alteram a cinemática natural dos sistemas aqüíferos específicos e vizinhos, (REBOUÇAS op. cit.).

Os volumes de águas subterrâneas encontram-se estocados sob as formas de reservas reguladoras e reservas permanentes.

As reservas reguladoras correspondem aos volumes das recargas anuais. A sua determinação pode ser efetuada pelos seguintes métodos: 
(1) seção de fluxo ou de Darcy

$$
\mathrm{Rr}=\mathrm{Q}=\mathrm{T} \times \mathrm{I} \times \mathrm{L}
$$

(2) volumétrico - tendo-se por base a variação sazonal $(\mathrm{dh})$ dos niveis de água numa rede de poços de monitoramento $\mathrm{R}_{\mathrm{r}}=\mathrm{A} \times \mathrm{dh} \times \mu$ ou $\mathrm{S}$

(3) recessão dos rios

$$
\operatorname{Rr}=Q_{0 \times} 86.400 / \alpha
$$

De acordo com as interpretações das seções hidrogeológicas, estas sugerem que o sistema aqǘffero em apreço apresenta um comportamento do tipo livre, cujo nível potenciométrico flutua com as variações sazonais. MELO (1995) quando definiu o modelo conceitual hidrogeológico da zona sul da cidade de Natal, verificou tal comportamento. Nestas condições, normalmente as potencialidades do aqüifero estão condicionadas a infiltração direta das águas de chuva. Nestes estudos preliminares, não foi possível conhecer as flutuações sazonais dos níveis d'água, portanto para a avaliação das reservas reguladoras foi utilizada a metodologia através do fluxo de Darcy, que por definição as reservas reguladoras são equivalentes à vazão do fluxo subterrâneo, $(\mathrm{Q}=\mathrm{Rr})$. Conforme avaliações efetuadas com base no mapa de fluxo e características hidráulicas do aqǘfero, obteve-se uma descarga natural de $76,0 \mathrm{x}$ $10^{6} \mathrm{~m}^{3} /$ ano, valor estimado para as reservas reguladoras.

As reservas permanentes constituem os volumes estocados abaixo do limite inferior da variação sazonal dos aqüíferos livres ou dos níveis potenciométricos dos aqüíferos confinados. No curso inferior da bacia, estas reservas foram estimadas em função da área correspondente a $118 \mathrm{~km}^{2}$, uma espessura saturada efetiva média de 30 metros e porosidade específica de $10 \%$. Os respectivos valores aplicados na equação seguinte, indicou reservas permanentes da ordern de $354 \times 10^{6} \mathrm{~m}^{3} / \mathrm{ano}$.

$\mathbf{R}_{\mathrm{p}}=\mathbf{A} . \mathbf{E}_{\mathrm{m} \cdot \boldsymbol{\mu}}, \quad$ onde;

$\mathbf{R}_{\mathbf{p}}=$ reservas permanentes $\left(\mathrm{m}^{3} / \mathrm{ano}\right)$;

$\mathbf{A}=$ área $\left(118 \mathrm{Km}^{2}\right)$;

$\mathbf{E}_{\mathbf{m}}=$ espessura mínima do aqüífero $(30 \mathrm{~m})$;

$\mu=$ porosidade especifica estimada $(10 \%)$.

Considerando a equação $R_{r}=A x d h \times \mu$ e que as reservas reguladoras (Rr) são equivalentes a vazão de fluxo $(\mathrm{Q})$, então tem-se : $\mathrm{Q}=\mathrm{A} \times \mathrm{dh} \times \mu, \log \mathrm{o}: \mathrm{dh}=\mathrm{Q} / \mathrm{A} \times \mu$. 
A partir desta aplicação obteve-se uma variação de carga (dh) igual a 6,4 metros, valor aproximado ao obtido por MELO (1998) que foi de 7,0 metros. Tendo-se uma precipitação média da ordem de $1.500 \mathrm{~mm} /$ anuais, o volume precipitado no domínio da área de $118 \mathrm{~km}^{2}$, é da ordem de $177 \times 10^{6} \mathrm{~m}^{3} / \mathrm{ano}$. Considerando que a infiltração eficaz é de $76,0 \times 10^{6} \mathrm{~m}^{3} / \mathrm{ano}$ tem-se uma taxa de infiltração equivalente a $43 \%$ aproximadamente igual ao valor avaliado por MELO op. cit. que foi de $44 \%$ para a zona norte de Natal.

Atualmente a explotação de água subterrânea é da ordem de $21,3 \times 10^{6} \mathrm{~m}^{3} / \mathrm{ano}$, correspondente a $50 \%$ do consumo total da bacia e a $28 \%$ das reservas reguladoras. A tabela 4.4 compreende o resumo dos valores estimados do sistema aqüífero Dunas/Barreiras, no curso inferior da bacia do rio Doce.

Tabela 4.4 - Resumo dos valores estimados relacionados ao Sistema Aqüífero Dunas/Barreiras do curso inferior da Bacia do Rio Doce

\begin{tabular}{|l|l|}
\hline Parâmetros Determinados & Valores obtidos \\
\hline Area $\left(\mathrm{Km}^{2}\right)(\mathrm{A})$ & $118 \mathrm{Km}^{2}$ \\
\hline Precipitação média anual (mm) P & $1.500 \mathrm{~mm}$ \\
\hline Volume no Domínio da área $(\mathrm{mm})(\mathrm{A} \times \mathrm{P})$ & $177 \times 10^{6} \mathrm{~m}^{3} / \mathrm{ano}$ \\
\hline *Descarga do fluxo subterrâneo $\left(\mathrm{m}^{3} / \mathrm{ano}\right)(\mathrm{Q})$ & $76 \times 10^{6} \mathrm{~m}^{3} / \mathrm{ano}$ \\
\hline *Taxa de infiltração eficaz $(\%)$ & $43 \%$ \\
\hline *Reservas Reguladoras $\mathrm{Rr}=\mathrm{Q}\left(\mathrm{m}^{3} / \mathrm{ano}\right)$ & $76 \times 10^{6} \mathrm{~m}^{3} / \mathrm{ano}$ \\
\hline *Reservas Permanentes $\mathrm{Rp}\left(\mathrm{m}^{3} / \mathrm{ano}\right)$ & $354 \times 10^{6} \mathrm{~m}^{3 / a n o}$ \\
\hline $\begin{array}{l}\text { Explotação atual de água subterrânea } \\
\left.\text { (Sistema Aqüifero Dunas/Barreiras }-\mathrm{m}^{3} / \mathrm{ano}\right)\end{array}$ & $21 \times 10^{6} \mathrm{~m}^{3} / \mathrm{ano}$ \\
\hline * Parâmetros estimados & \\
\hline
\end{tabular}

Fonte: (CASTRO, 2000)

$\mathrm{Na}$ figura 4.4 estão apresentados estes parâmetros estimados no contexto do comportamento hidrogeológico do sistema aqüifero Dunas/Barreiras. 


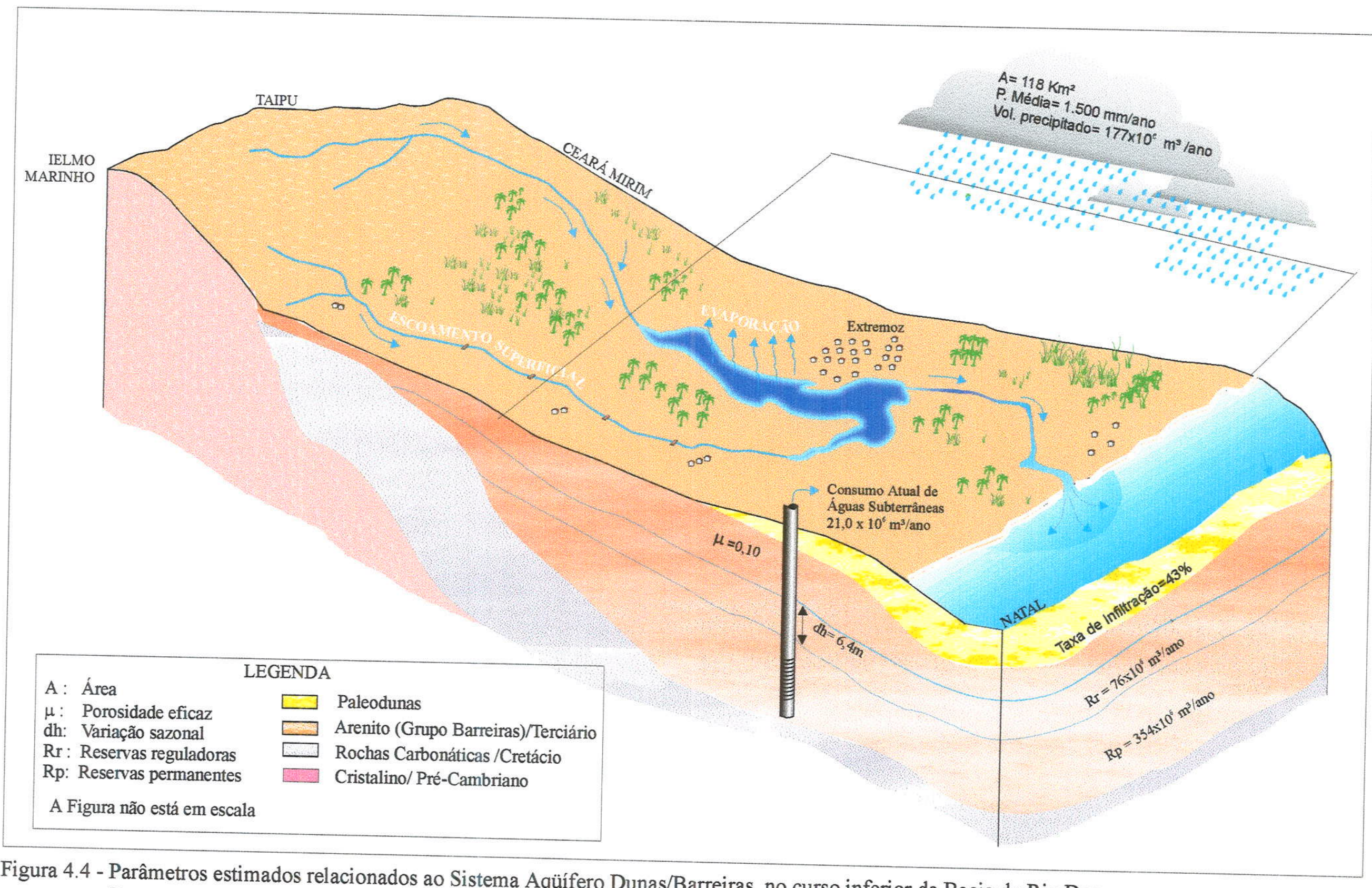

Figura 4.4 - Parâmetros estimados relacionados ao Sistema Aqüífero Dunas/Barreiras no curso inferior da Bacia do Rio Doce
Fonte: (CASTRO, 


\subsection{5 -Estimativa da Contribuição do Volume de Água Proveniente do Aqüífero Barreiras Para a Lagoa de Extremoz}

A lagoa de Extremoz, com uma área de $4,0 \mathrm{~km}^{2}$ e um volume de $9,0 \times 10^{6} \mathrm{~m}^{3}$, constitui um expressivo manancial da rede hidrográfica da bacia do no Doce e recebe contribuições das águas subterrâneas e superficiais dos rios do Mudo e Guajiru, cujas descargas médias são da ordem de 0,28 e $0,26 \mathrm{~m}^{3} / \mathrm{s}$ respectivamente. É drenada a jusante pelo rio Doce com descarga média de $0,39 \mathrm{~m}^{3} / \mathrm{s}$. Os rios do Mudo e Guajiru ao longo de seus $25 \mathrm{~km}$ de extensão, são perenes a partir do trecho que fica aproximadamente a $5 \mathrm{~km}$ da área de descarga na lagoa, em uma cota topográfica de aproximadamente 30 metros, onde recebem exudações do sistema aqüifero Dunas/Barreiras.

Para realizar um balanço das entradas e saidas de água de um determinado sistema que contempla as descargas de rios é necessário uma série histórica de dados fluviométricos na bacia. A falta de dados impossibilitou que a realização de uma simulação com um certo grau de confiabilidade fosse realizada. Neste sentido, foi efetuada uma avaliação com valores estimados a partir de alguns dados observados em um curto espaço de tempo. Portanto, o tratamento dado a este assunto neste capítulo é a nivel de uma avaliação preliminar, cujas informações utilizadas estão apresentadas na tabela 4.5 . Tabela 4.5 - Parâmetros utilizados em uma simulação preliminar das entradas e saídas anuais de
água na lagoa de Extremoz

\begin{tabular}{|l|l|l|}
\hline Parâmetros Utilizados & Valores obtidos & Fonte \\
\hline Area da Lagoa & $4,0 \mathrm{Km}^{2}$ & CAERN \\
\hline Volume da Lagoa & $9,0 \times 10^{6} \mathrm{~m}^{3}$ & CAERN \\
\hline Descarga do Rio do Mudo & $0,28 \mathrm{~m}^{3} / \mathrm{s}$ & $\begin{array}{l}\text { Resultados da média de medições realizadas no período } \\
\text { chuvoso e de verão }\end{array}$ \\
\hline Descarga do Rio Guajiru & $0,26 \mathrm{~m}^{3} / \mathrm{s}$ & $\begin{array}{l}\text { Resultados da média de medições realizadas no período } \\
\text { chuvoso e de verão }\end{array}$ \\
\hline Descarga do Rio Doce & $0,39 \mathrm{~m}^{3} / \mathrm{s}$ & $\begin{array}{l}\text { Resultados da média de medições realizadas no período } \\
\text { chuvoso e de verão }\end{array}$ \\
\hline Evaporação & $\begin{array}{l}\text { Estimada com base em dados de outros corpos d' água da } \\
\text { região com características ambientais semelhantes; }\end{array}$ \\
\hline Precipitação & $\begin{array}{l}\text { Resultado da média de uma série histórica de 1961 a 1979 } \\
\text { obtida na estação meteorológica de Natal. }\end{array}$ \\
\hline Volume atual explorado da lagoa & $21,6 \times 10^{6} \mathrm{~m}^{3} / a n o$ & \begin{tabular}{l} 
Cadastro dos usuários efetuado no âmbito desta pesquisa \\
\hline
\end{tabular} \\
\hline Fonte: (CASTRO, 2000) &
\end{tabular}


A partir do conhecimento do consumo atual de água da lagoa associado a estimativa de alguns parâmetros hidrológicos foi possível sugerir um esquema ilustrativo, do comportamento das entradas e saídas de água no sistema lacustre em apreço, (figura.4.5).

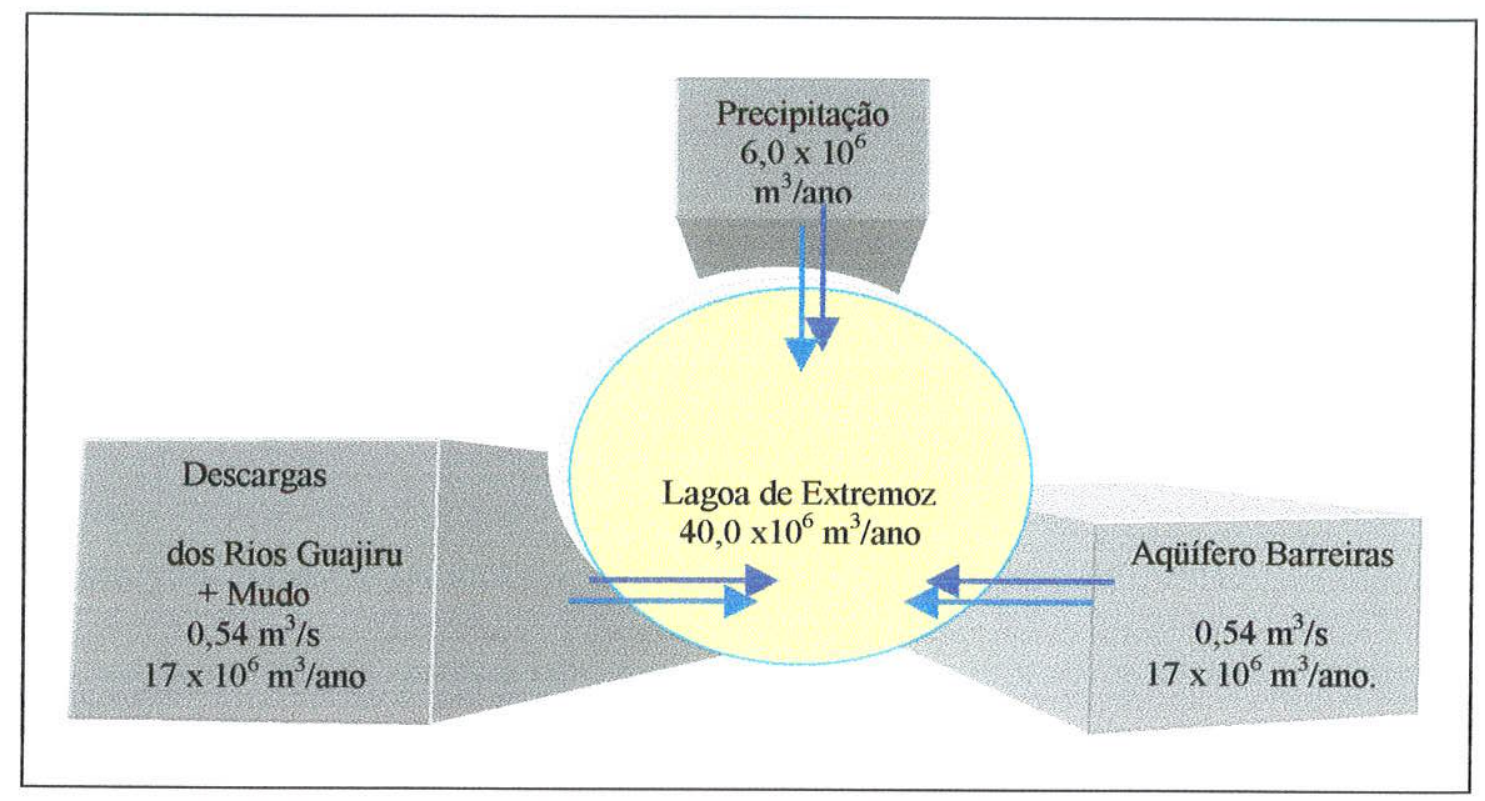

(a)

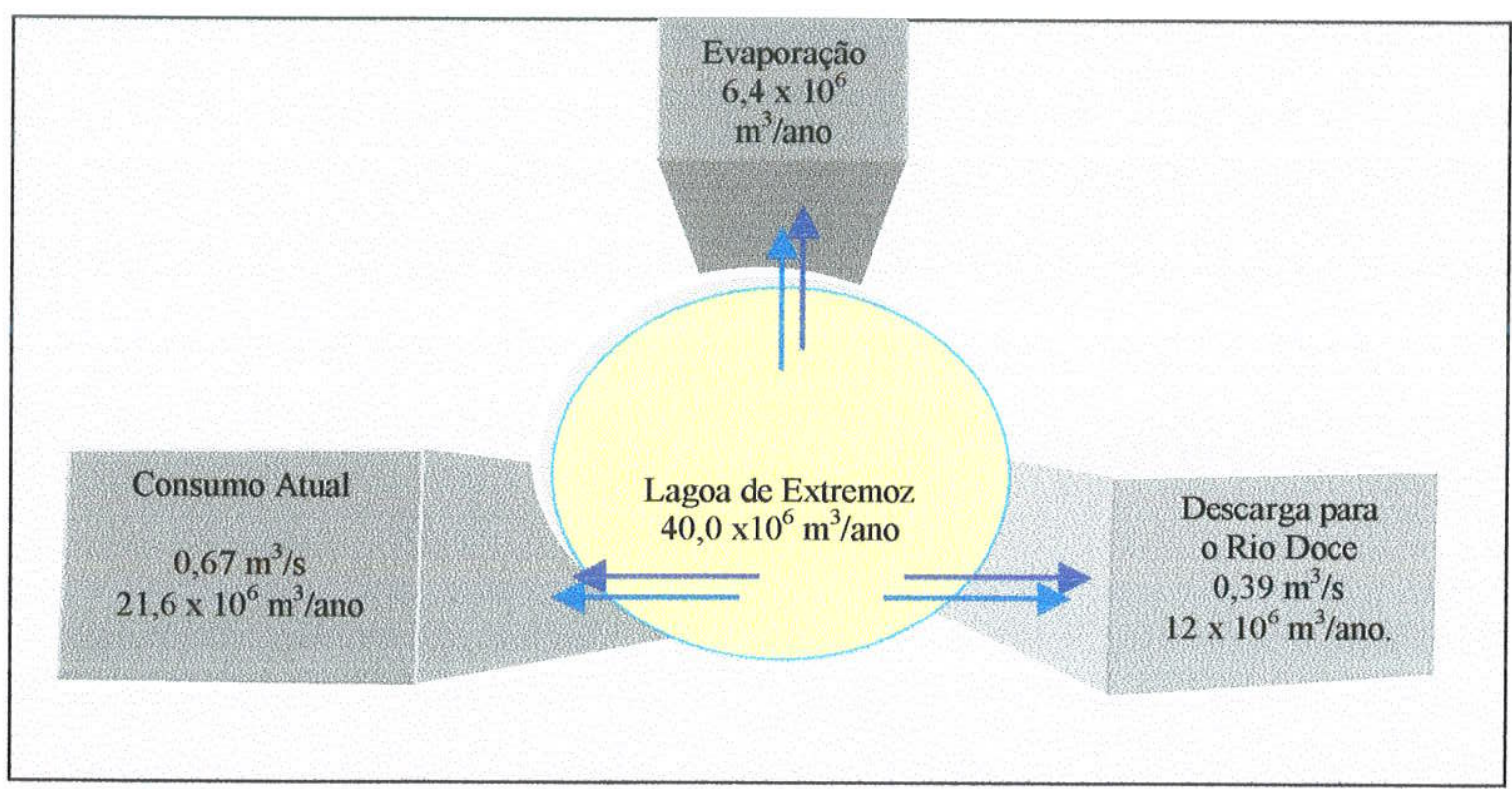

(b)

Figura 4.5 - Simulação preliminar das entradas (a) e saídas (b) anuais de água na lagoa de Extremoz

Fonte: (CASTRO, 2000) 
No referido esquema ilustrativo, (figura 4.5), os exutórios da lagoa de Extremoz, são representadas pela descarga para o rio Doce, que é de $0,39 \mathrm{~m}^{3} / \mathrm{s}$ equivalente a $12,0 \times 10^{6} \mathrm{~m}^{3} /$ ano, pela evaporação que foi estimada em $4,5 \mathrm{~mm} / \mathrm{dia}$, correspondendo a $6,4 \times 10^{6} \mathrm{~m}^{3} /$ ano e pelo consumo atual equivalente a $0,67 \mathrm{~m}^{3} / \mathrm{s}$ representando $21,6 \times 10^{6} \mathrm{~m}^{3} / \mathrm{ano}$, de forma que as saidas de água compreende atualmente um volume anual estimado em $40 \times 10^{6} \mathrm{~m}^{3}$. Ressalta-se para o fato de que as medições das descargas mencionadas, referem-se a um ano, cujas precipitações foram abaixo da média anual (menor que $1500 \mathrm{~mm}$ ).

No que se refere ao volume de água que entra anualmente no sistema lacustre tem-se o volume médio anual de água precipitado na lagoa, que foi estimado em $6,0 \times 10^{6} \mathrm{~m}^{3} / \mathrm{ano}$, a soma das descargas dos rios do Mudo e do Guajiru, que correspondem a $0,54 \mathrm{~m}^{3} / \mathrm{s}$ equivalente a $17 \times 10^{6} \mathrm{~m}^{3} /$ ano e o aporte de água subterrânea que foi estimado em $0,54 \mathrm{~m}^{3} / \mathrm{s}$ correspondente a $17 \times 10^{6} \mathrm{~m}^{3} / a n o$, representando um aporte de água de $40 \mathrm{~m}^{3} / a n o$.

Em face a estas avaliações preliminares, verifica-se que a contribuição das águas subterrâneas para a lagoa de Extremoz constitui atualmente uma cifra de $42 \%$ em relação ao volume de aporte anual.

\section{4-Aqüífero Aluvial}

Os depósitos aluviais do RN, são constituídos, em média, por $70 \%$ de areias, variando de areias finas a grosseiras e bastante permeáveis, (DINIZ FILHO, 1993). Na área estudada, o aquúfero aluvial constitui-se por sedimentos clásticos fluviais, representados por areias, argilas e cascalho. Na porção inferior os perfis mostram a predominância das frações arenosas médias a grosseiras e poucas intercalações argilosas. Em direção ao topo ocorrem as frações arenosas finas, argilosas, com maior frequêencia de intercalações argilosas. No curso superior dos rios do Mudo e Guajiru os sedimentos aluviais ocorrem sobreposto às rochas cristalinas, com larguras médias de 50 metros. No médio e baixo curso apresentam-se sobre os terrenos sedimentares da Formação Barreiras, conectando-se hidraulicamente em um sistema único, de modo que o aproveitamento do seu potencial hídrico é insignificante, já que os poços tubulares e poços amazonas cadastrados indicaram captação apenas do aquǘfero Barreiras. Desta forma não foi possível efetuar uma caracterização hidrodinâmica deste aqüifero. 


\section{0 - QUALIDADE DAS ÁGUAS E CARACTERIZAÇÃO HIDROQUÍMICA}

Apenas $2,7 \%$ da água do planeta é doce e desse total $98 \%$ correspondem as águas subterrâneas. Dentro desse contexto a água doce é um recurso indivisível e requer um manejo holístico. No ciclo hidrológico circula água pura, uma vez que o processo evaporaçãoprecipitação age como um destilador. Após a água atingir a superficie, inicia-se um processo de dissolução e arraste que transportará material retirado do solo até os rios e oceanos. Nessa fase a água adquire outros elementos como cálcio, magnésio, sódio, bicarbonatos, cloretos, sulfatos, nitratos e traços de alguns metais como chumbo, cobre, manganês e outros compostos orgânicos provenientes dos processos de decomposição do solo. Dessa forma o comportamento hidroquímico das águas passa a sofrer variações com o clima, a geologia local, a vegetação e ação antropogênica.

O clima influencia na decomposição das rochas e erosão do solo e, dependendo do tipo de rocha, aparecerão em maior quantidade aqueles elementos que fazem parte de sua composição. No entanto, os problemas mais graves que afetam a qualidade da água são decorrentes da ação antropogênica, principalmente no que se refere à falta de saneamento básico e práticas agrícolas deficientes. Os esgotos urbanos lançam efluentes orgânicos, as indústrias uma série de compostos sintéticos e metais pesados, a agricultura é responsável pela presença de pesticidas e excesso de fertilizantes na água. As atividades humanas representam a maior ameaça à qualidade da água.

Atualmente esta tendência é um dos principais problemas dos recursos hídricos no país. As regiões metropolitanas se expandem na periferia, onde normalmente se concentram os mananciais superficiais que são mais susceptiveis de sofrerem contaminações do que as águas subterrâneas. Entretanto, a contaminação de aquúiferos é mais preocupante, tendo em vista que os mananciais de superficie se renovam e se recuperam após cessar o lançamento dos contaminantes.

No caso das águas subterrâneas, a descontaminação do aqüifero até um nível zero de concentração não pode ser obtida. A um custo financeiro bastante elevado, consegue-se remediar esta contaminação a um nível aceitável acima de zero (CLEARY, 1992).

As impurezas mais comuns encontradas em águas naturais estão apresentados no quadro 5.1. 
Quadro 5.1 - Impurezas mais freqüentes encontradas nas águas naturais

\begin{tabular}{|c|c|c|c|c|}
\hline Origem & Impurezas Dissolvidas & Coloidais & Em Suspensão & Gases \\
\hline $\begin{array}{l}\text { Contato da água } \\
\text { com minerais, } \\
\text { solos e rochas }\end{array}$ & \begin{tabular}{|ll} 
Cálcio & Bicarbonatos \\
Ferro & Carbonatos \\
Magnésio & Cloretos \\
Manganês & Nitratos \\
Potássio & Fosfatos \\
Sódio & Silicatos \\
Zinco & Sulfatos
\end{tabular} & $\begin{array}{l}\text { Argila } \\
\text { Sílica } \\
\text { Óxido de Ferro } \\
\text { Óxido de Alumínio } \\
\text { Dióxido de Magnésio }\end{array}$ & $\begin{array}{l}\text { Argila } \\
\text { Silte } \\
\text { Areia }\end{array}$ & Gás Carbônico \\
\hline $\begin{array}{l}\text { Atmosfera, } \\
\text { Chuva }\end{array}$ & $\begin{array}{ll}\text { Hidrogênio } & \text { Cloreto } \\
\text { Bicarbonato } & \text { Sulfato }\end{array}$ & & $\begin{array}{l}\text { Poeira } \\
\text { Pólen }\end{array}$ & $\begin{array}{l}\text { Gás Carbónico } \\
\text { Nitrogênio } \\
\text { Oxigênio } \\
\text { Dióxido de Enxofre }\end{array}$ \\
\hline $\begin{array}{l}\text { Decomposição } \\
\text { de } \quad \text { matéria } \\
\text { orgànica r no } \\
\text { meio ambiente }\end{array}$ & \begin{tabular}{|lc} 
Amônia & Cloretos \\
Hidrogênio & Nitritos \\
Sódio & Nitratos \\
Sulfitos & Radicais Orgânicos
\end{tabular} & $\begin{array}{l}\text { Cor de origem vegetal } \\
\text { Residuos }\end{array}$ & $\begin{array}{l}\text { Solo Orgânico } \\
\text { Residuos } \\
\text { Orgânicos }\end{array}$ & $\begin{array}{l}\text { Amônia Metano } \\
\text { Hidrogênio } \\
\text { Nitogênio Oxigênio } \\
\text { Gás sulfidrico } \\
\text { Gás Carbônico }\end{array}$ \\
\hline $\begin{array}{l}\text { Organismos } \\
\text { vivos }\end{array}$ & & $\begin{array}{l}\text { Bactérias Algas } \\
\text { Vírus }\end{array}$ & $\begin{array}{l}\text { Algas } \\
\text { Zooplâncton } \\
\text { Peixes }\end{array}$ & $\begin{array}{l}\text { Amônia } \\
\text { Gás Carbônico } \\
\text { Metano }\end{array}$ \\
\hline $\begin{array}{l}\text { Fontes } \\
\text { antropogênicas }\end{array}$ & $\begin{array}{l}\text { Ions Inorgânicos } \\
\text { Metais Pesados } \\
\text { Moléculas Orgânicas } \\
\text { Cor }\end{array}$ & $\begin{array}{l}\text { Organoclorados } \\
\text { Corantes bactérias } \\
\text { Vírus }\end{array}$ & $\begin{array}{l}\text { Sólidos } \\
\text { Inorgânicos } \\
\text { Compostos } \\
\text { Orgânicos } \\
\text { Óleos e Graxas }\end{array}$ & $\begin{array}{l}\text { Cloro } \\
\text { Dióxido de Enxofre }\end{array}$ \\
\hline
\end{tabular}

Fonte: (TCHOBANOGLOUS \& SCHROEDER, 1987)

\section{1 - Águas Superficiais} 5.1.1 - Comportamento de alguns paràmetros Físicos, Químicos, Biológicos e
Bacteriológicos no período de 1995 a 1996

A Companhia de Águas e Esgotos do Rio Grande do Norte (CAERN), realizou no período de 1995 a 1996 campanhas de amostragem das águas da lagoa de Extremoz, dos rios do Mudo, Guajiru e Doce (figura 5.1) e efetuou determinações dos seguintes parâmetros físicos, químicos, biológicos e bacteriológicos: Cor, Turbidez, $\mathrm{pH}$, Cloreto, Sólidos Totais Dissolvidos, Alcalinidade Total, Oxigênio Dissolvido (OD), Demanda Bioquímica de 
Oxigênio (DBO), Demanda Química de Oxigênio (DQO), Coliformes Totais e Coliformes Fecais.

\subsubsection{1 - Cor e Turbidez}

A cor da água é resultado principalmente dos processos de decomposição que ocorrem no meio ambiente. Por esse motivo, as águas superficiais estão mais propensas a possuir cor do que as águas subterrâneas.

As variações de cor e turbidez que um corpo d' água possa apresentar devem-se à existência, no meio líquido, de pigmentos que lhe confiram essas características. Os fatores que influenciam as condições ecológicas em um rio ou lago, relacionadas à luz, são a cor e a turbidez do meio, pois estes dois parâmetros afetam a disponibilidade de energia luminosa para os organismos fotossintetizantes (BRANCO, 1986). As substancias responsáveis pela variação da cor geralmente encontram-se na forma coloidal ou em dissolução, enquanto que a turbidez é originada por partículas insolúveis que se mantêm em suspensão.

BRICAUD et al. (1981) em estudos realizados em águas oceânicas apresentaram quatro grupos de substancias presentes na água, capazes de causar alterações em suas propriedades ópticas:

- fitoplâncton vivo;

- detritos biogênicos e associados;

- partículas terraginosas e sedimentares suspensos

- matéria orgânica dissolvida

Os esgotos domésticos e industriais, assim como as águas de escoamento superficial são ricos em partículas orgânicas e inorgânicas que causam alterações nessas propriedades. Os organismos vivos como as bactérias e as algas também causam alterações desses parâmetros.

As águas naturais possuem cor que varia entre 0 e 200 unidades pois, acima disso, já seriam águas de pântano com altos teores de matéria orgânica dissolvida (HEM, 1985). Coloração abaixo de 10 unidades quase não é perceptível. No Brasil, aceita-se para água bruta, ou seja, antes de ser tratada e distribuída para sistemas urbanos, valores de até 75 unidades de cor (Resolução CONAMA 20/86). 


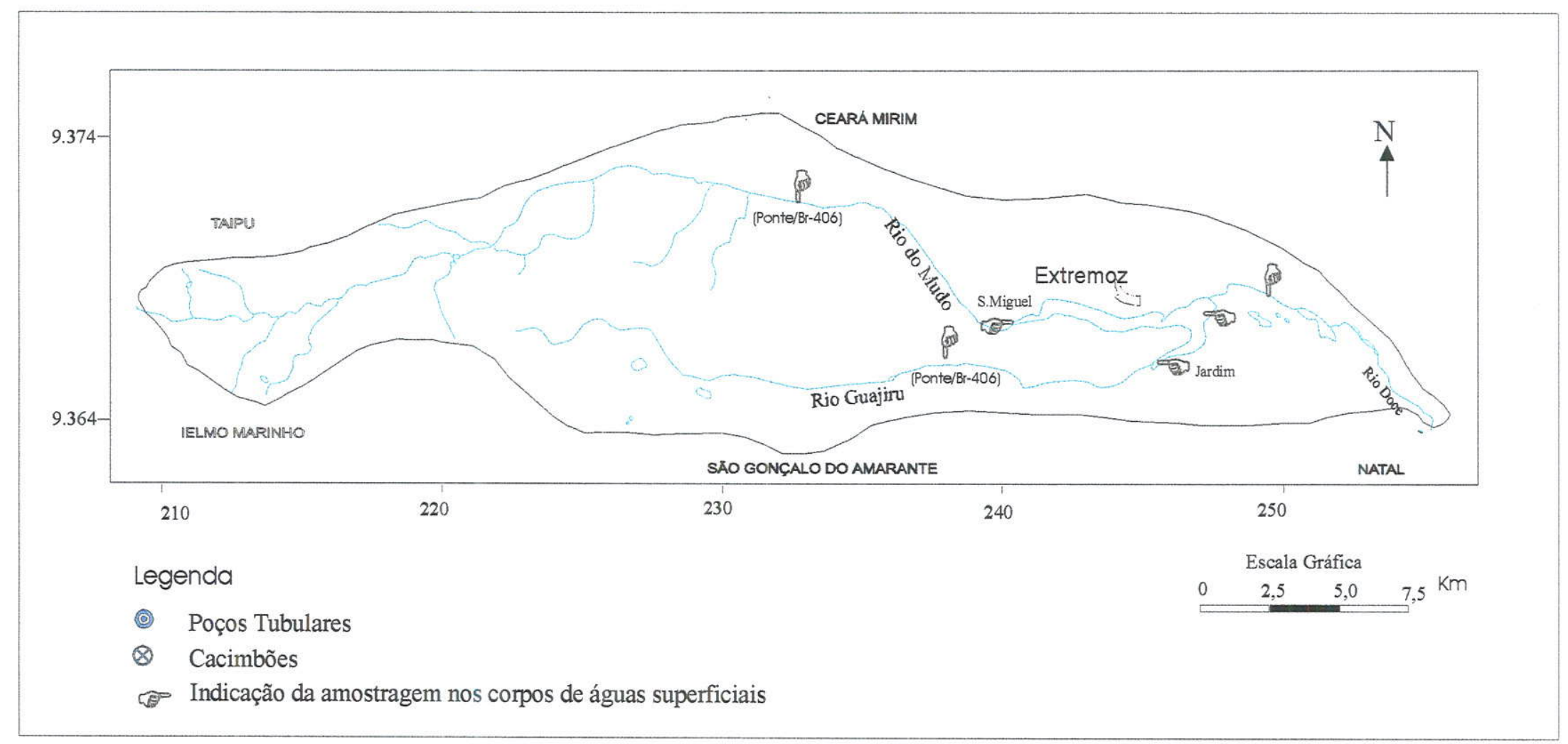

Figura 5.1 - Localização dos pontos de amostragem das análises físicas, químicas, biológicas, e bacteriológicas realizadas pela CAERN no período de 1995 a 1996

Fonte: (CASTRO, 2000) 
$\mathrm{Na}$ lagoa de Extremoz, manancial com uso principal para o abastecimento público, as análises desse parâmetro indicaram um valor máximo de $55,0 \mathrm{u}^{\mathrm{H}}$ e um valor mínimo de $3,0 \mathrm{u}^{\mathrm{H}}$ com uma média igual a $26,6 \mathrm{u}^{\mathrm{H}}$.

Quanto à turbidez, no Brasil, admite-se que as águas naturais que possuam turbidez de até 100 UNT possam ser utilizadas para o abastecimento urbano (Resolução CONAMA 20/86). Valores de turbidez até esse limite podem ser removidos por tratamento convencional de água. A água tratada deve ter turbidez inferior a 5 UNT porque o material em suspensão permite que ocorram áreas em que eventuais microorganismos patogênicos presentes não entrem em contato com a substância desinfetante (PORTO et al. 1991).

Na lagoa de Extremoz foi verificado que a turbidez apresentou uma variação de 1,0 a $22,0 \mathrm{u}^{\mathrm{T}}$ e um valor médio de $5,1 \cdot \mathrm{u}^{\mathrm{T}}$.

\section{$5.1 .1 .2-\mathrm{pH}$}

$\mathrm{O}$ pH controla a especiação química das águas. Os critérios de proteção da vida aquática fixam o $\mathrm{pH}$ entre $6 \mathrm{e}$ 9. Muitos peixes e outros animais aquáticos podem sobreviver a valores iguais ou menores que 5,0, mas a este pH os metais se solubilizam muito facilmente, aumentando as possibilidades de toxidez. Acima do pH 6,0 há uma melhora na pesca e na agricultura (PORTO et al. 1991).

Os valores médios de $\mathrm{pH}$ variaram de 6,7 no rio Doce (jusante) a 7,2 no rio do Mudo (montante). Esse aumento do pH em direção a montante deverá estar associado a presença de rochas carbonáticas em subsuperficie. Ou seja, nestes locais onde os mananciais de superficie recebem contribuições das águas subterrâneas do aq̣üf́fero Barreiras, misturadas às águas provenientes do aqüífero Jandaíra, constituído por rochas carbonáticas, ocorre um aumento nos valores do $\mathrm{pH}$.

\subsubsection{3 - Alcalinidade Total}

A quantidade de ácido necessária para consumir todo o carbonato e/ou bicarbonato é chamada alcalinidade. A capacidade da água em neutralizar ácido não se deve exclusivamente aos tons $\mathrm{CO}_{3}^{--}$e $\mathrm{HCO}_{3}^{-}$(FENZL, 1988). Em grau menor, outros ions ou compostos são capazes de reagir com ácidos fortes e contribuir assim com à alcalinidade da água, como por exemplo: fosfatos, hidróxidos, certos compostos orgânicos, boratos e outros.

No rio do Mudo $(\mathrm{Br}-406)$, foi o local onde as análises das águas indicaram maior alcalinidade, apresentando um valor máximo de $158,4 \mathrm{mg} / \mathrm{L}\left(\mathrm{CaCO}_{3}\right)$, (março/95). 
Os valores mais baixos foram constatados na lagoa de Extremoz e rio Doce, cujos valores médios foram de 45,3 e 40,2 $\mathrm{mg} / \mathrm{L}\left(\mathrm{CaCO}_{3}\right)$, respectivamente.

Os valores de alcalinidade, caracterizados como sendo mais elevados à montante, (figura 5.2), justifica-se pela própria geologia da área, pois nesses locais ocorrem rochas carbonáticas em subsuperficie. Além desse fato, uma outra componente que interfere nesse comportamento, é devido a contribuição de um maior volume das águas subterrâneas, provenientes do sistema aqüífero Dunas/Barreiras, (caracterizadas como ácidas), para os corpos d'água superficiais à jusante.

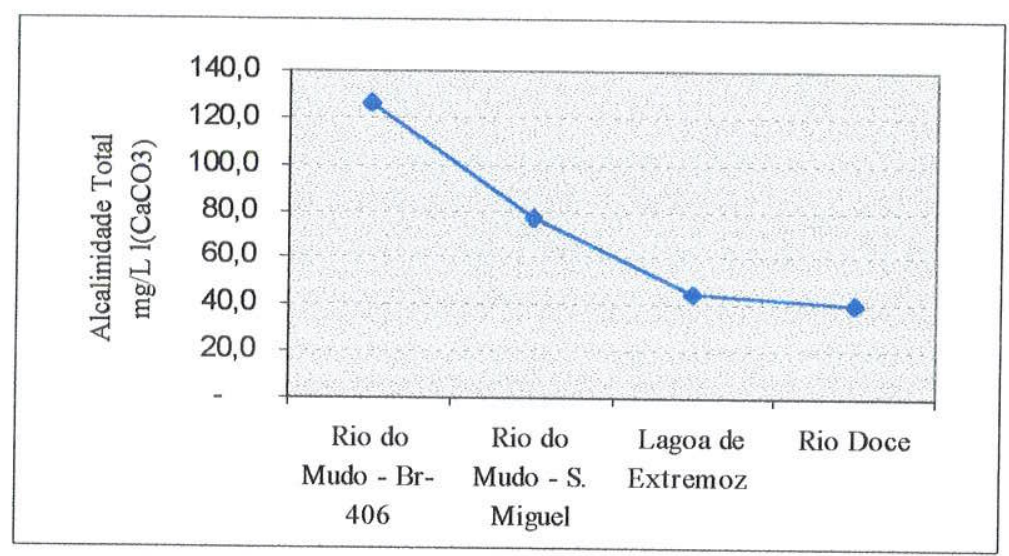

Figura 5.2 - Comportamento da alcalinidade total no perfil longitudinal Rio do Mudo (Br-406)/Rio Doce Fonte: (CASTRO, 2000)

\subsubsection{4 - Sólidos Totais Dissolvidos (STD)}

Em águas naturais superficiais, a concentração dos Sólidos Totais Dissolvidos (STD) indicam as taxas de desgaste das rochas por intemperismo. Em regiões com altos índices pluviométricos mas com rochas insolúveis como o granito, o escoamento superficial apresentará baixos valores de sólidos dissolvidos totais. Excesso de sólidos dissolvidos na água pode causar alterações de sabor e problemas de corrosão. Para as águas de abastecimento, permite-se um valor máximo de $500 \mathrm{mg} / \mathrm{L}$ de sólidos dissolvidos totais (Resolução CONAMA 20/86). Os limites estabelecidos pela Portaria do Ministério da Saúde N. ${ }^{\circ} 36 / 90$ e pela Organização Mundial de Saúde, (OMS), é de $1000 \mathrm{mg} / \mathrm{L}$.

A tabela 5.1 e o anexo 02 apresentam os resultados obtidos das análises realizadas no período de 1995 a 1996 e caracterizam os seguintes comportamentos:

- No rio do Mudo, na Br-406 e na Fazenda São Miguel, foram os locais, onde ocorreram as maiores concentrações de STD com valores máximos de 1.248,0 mg/L (junho/95) e 1.462 
$\mathrm{mg} / \mathrm{L}$ (julho/95) respectivamente. A concentração média foi de $589,8 \mathrm{mg} / \mathrm{L}$ (Rio do MudoBr-406) e de 544,9 na Fazenda São Miguel.

- Na lagoa de Extremoz o valor máximo obtido foi de $810 \mathrm{mg} / \mathrm{L}$ (julho/95) e a menor concentração foi de $240,0 \mathrm{mg} / \mathrm{L}$ (maio/96). A concentração média de STD foi de $343,3 \mathrm{mg} / \mathrm{L}$. - No rio Doce ocorreram as menores concentrações. O valor máximo foi de $692,0 \mathrm{mg} / \mathrm{L}$ (julho/95), a concentração mínima foi de 120,0 mg/L (janeiro/96) e a média foi de 266,9 $\mathrm{mg} / \mathrm{L}$.

De acordo com o perfil longitudinal Rio do Mudo/Lagoa de Extremoz/Rio Doce, figura 5.3, ocorre uma diminuição da concentração dos sólidos totais dissolvidos em direção a jusante. Também foi verificado que os valores máximos das concentrações de Sólidos Totais Dissolvidos, (STD), ocorreram principalmente no mês de julho, período chuvoso, enquanto que os valores mínimos ocorreram nos meses de baixas precipitações.

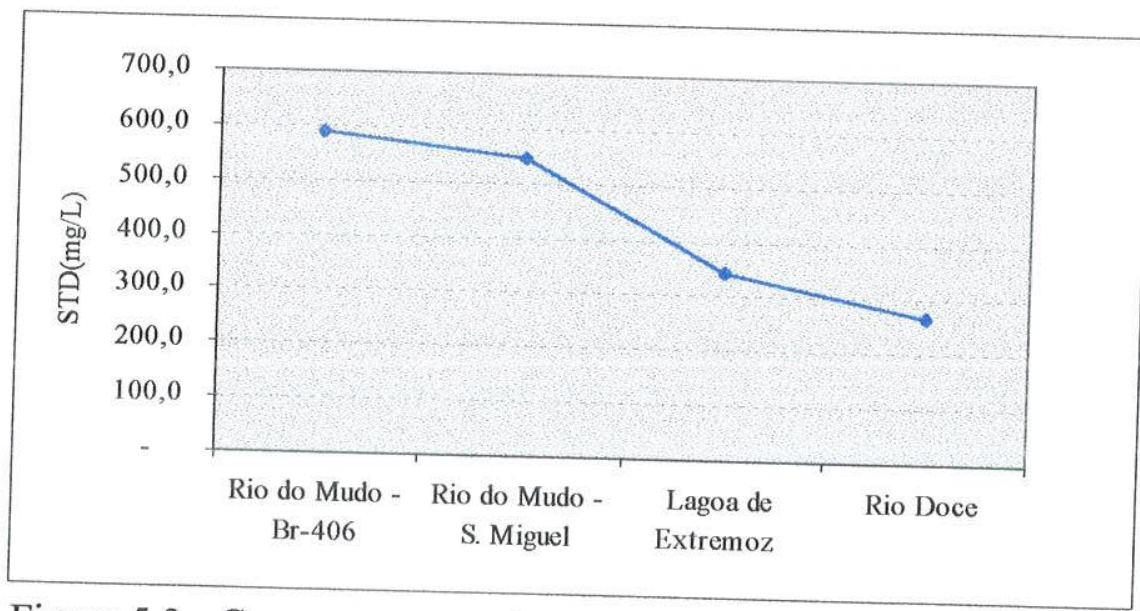

Figura 5.3 - Comportamento dos Sólidos Totais Dissolvidos (STD) no perfil longitudinal Rio do Mudo (Br-406)/Rio Doce Fonte: (CASTRO, 2000)

\subsubsection{5 - Cloreto}

Conforme os resultados das análises, (tabela 5.1 e anexo 02), verificou-se que o comportamento dos teores de cloreto, no período de março/95 a julho/96, mostraram:

- A montante dos rios do Mudo, (Br-406) e Guajiru (Br-406), foi onde ocorreram as maiores concentrações de Cloreto com valores máximos de 416,0 mg/L (março/95)e $322 \mathrm{mg} / \mathrm{L}$ (junho/96) respectivamente.

- Na lagoa de Extremoz os valores compreenderam uma faixa de $127 \mathrm{mg} / \mathrm{L}$ (set/95) a 75,0 $\mathrm{mg} / \mathrm{L}$ (março/95), apresentando uma concentração média de $101,4 \mathrm{mg} / \mathrm{L}\left(\mathrm{Cl}^{-}\right)$.

- No rio Doce o valor máximo foi de $152,0 \mathrm{mg} / \mathrm{L}$ (agosto/95), a concentração mínima foi de $46,0 \mathrm{mg} / \mathrm{L}$ (janeiro/96) e a média foi de $70,2 \mathrm{mg} / \mathrm{L}$. 
Diante desses registros foi observado que existe uma relação entre o período chuvoso e os teores máximos de cloreto nos rios do Mudo (Br-406), Guajiru (Br-406) e lagoa de Extremoz, como mostra a figura 5.4.
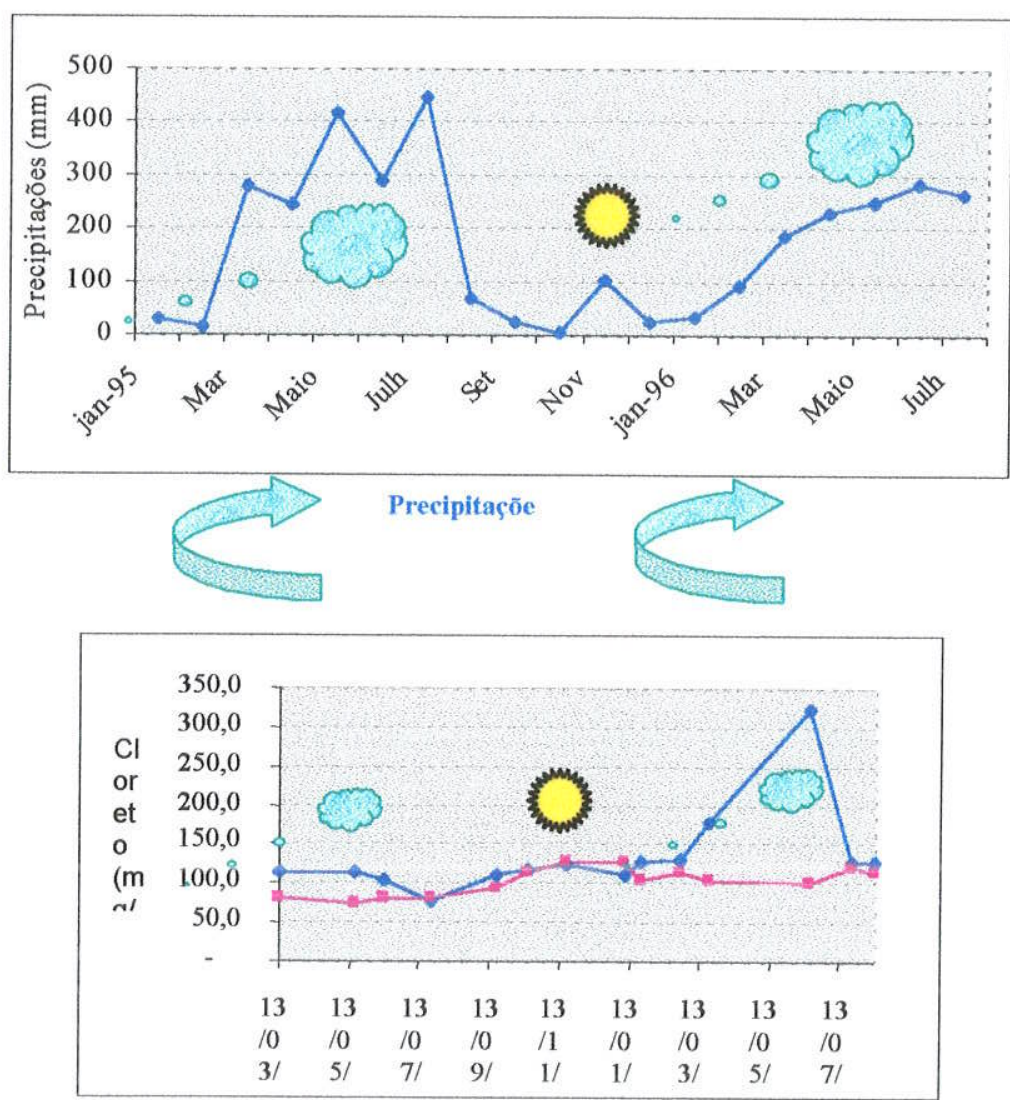

Rio Guajiru $\quad$ Lagoa de Extremoz

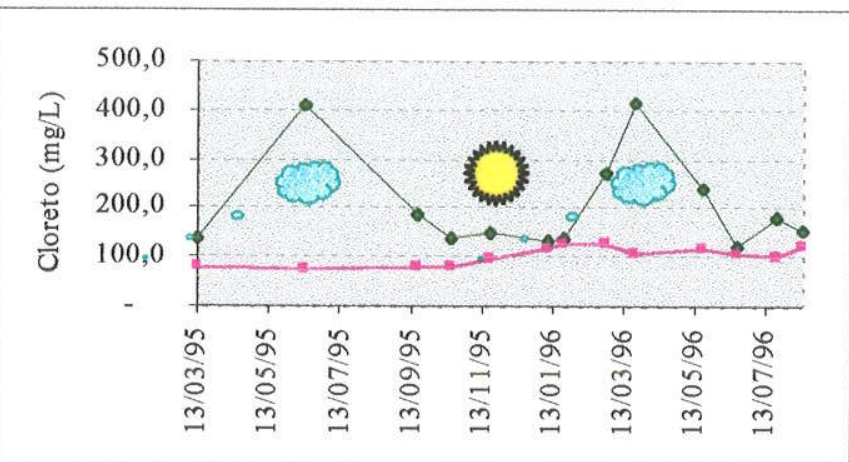

Rio do Mudo

Lagoa de Extremoz

Figura 5.4 - Relação entre as concentrações de cloreto $\left(\mathrm{Cl}^{-}\right)$e as precipitações nos rios Guajiru, do Mudo e lagoa de Extremoz no período de março/95 a março/96

Fonte: (CASTRO, 2000) 
Esse comportamento sugere, que associado as precipitações ocorrem os processos de lixiviação e arraste de materiais rochosos com elevadas concentrações de cloreto, uma vez que no alto curso da bacia, (extremo oeste da área), afloram as rochas do embasamento cristalino.

\subsubsection{6 - Oxigênio Dissolvido (OD) e Demanda Bioquímica de Oxigênio (DBO)}

O oxigênio é um gás pouco solúvel em água, variando a solubilidade entre 14,6 $\mathrm{mg} / \mathrm{L}$ a $0^{\circ} \mathrm{C}$ até $7,6 \mathrm{mg} / \mathrm{L}$ a $30^{\circ} \mathrm{C}$, dependendo da pressão (altitude) e sais dissolvidos. Em águas poluidas, a quantidade de oxigênio dissolvido numa água é menor que em condições naturais. Por razões práticas, assume-se que $8 \mathrm{mg} / \mathrm{L}$ seja o teor máximo de dissolução de oxigênio na pior situação ambiental, PORTO et al. (1991). Em corpos d' água, as medidas de OD são vitais para a manutenção de condições oxidantes (aeróbicas) para degradar a matéria orgânica e para manter, por exemplo, o fósforo no sedimento de lagos.

A Demanda Bioquímica de Oxigênio (DBO) é a quantidade de oxigênio necessária para que microorganismos estabilizem, por via biológica aeróbica, o material de natureza orgânica contido na água, OLIVEIRA (1994). A DBO tem sido o parâmetro de maior aplicação na caracterização de esgotos domésticos e industriais, para quantificar seu potencial poluidor. Como o oxigênio consumido aumenta com o decorrer do tempo e a atividade biológica depende da temperatura, convencionou-se tomar a 5 dias e a $20^{\circ} \mathrm{C}$ como medida padrão para expressar o teor de matéria orgânica presente na água. Por durar 5 dias, os resultados são expressos em termos de $\mathrm{DBO}_{5}$.

De acordo com a Resolução CONAMA No $20 / 86$ foi estabelecido que para as águas doces de classe especial o Oxigênio Dissolvido (OD) em qualquer amostra não deverá ser inferior a $6 \mathrm{mg} / \mathrm{L}$, enquanto que a Demanda Bioquímica de Oxigênio $\left(\mathrm{DBO}_{5}\right)$ deverá ser até $3 \mathrm{mg} / \mathrm{L}$ a $20^{\circ} \mathrm{C}$.

Os locais onde foram avaliados estes parâmetros apresentaram o seguinte comportamento:

No rio do Mudo (Br-406) o valor máximo para o OD foi de 7,0 $\mathrm{mg} / \mathrm{L}$ e o mínimo de $3,8 \mathrm{mg} / \mathrm{L}$. A DBO5 apresentou um valor máximo de $3,2 \mathrm{mg} / \mathrm{L}$ e um mínimo de $0,5 \mathrm{mg} / \mathrm{L}$.

No rio Guajiru o OD apresentoumse mais elevado na Fazenda Jardim, com 8,4 $\mathrm{mg} / \mathrm{L}$. Nesse local o valor mínimo foi de $1,2 \mathrm{mg} / \mathrm{L}$ e a $\mathrm{DBO}_{5}$ apresentou uma variação de 0,4 $\mathrm{mg} / \mathrm{L}$ a $2,5 \mathrm{mg} / \mathrm{L}$. 
Na lagoa de Extremoz foi determinado um valor máximo de OD de $8,0 \mathrm{mg} / \mathrm{L}$ e um mínimo de $3,4 \mathrm{mg} / \mathrm{L}$. A $\mathrm{DBO}_{5}$ apresentou apresentou uma variação de $0,1 \mathrm{mg} / \mathrm{L}$ a 4,3 $\mathrm{mg} / \mathrm{L}$.

No rio Doce as análises do OD indicaram uma variação de 3,4 a $7,5 \mathrm{mg} / \mathrm{L}$ enquanto que para a $\mathrm{DBO}_{5}$, foi obtido um valor máximo de $3,5 \mathrm{mg} / \mathrm{L}$ e um mínimo de 0,4 $\mathrm{mg} / \mathrm{L}$.

\subsubsection{7-Coliformes Fecais}

O Número Mais Provável (NMP) de bactérias coliformes visa avaliar o potencial de contaminação da água por patogênicos de origem fecal. Baseia-se na determinação empírica da concentração de coliformes fecais em um volume dado de água. As bactérias do grupo coliforme não são, normalmente, patogênicas, mas são organismos de presença obrigatória, em grandes números, nos intestinos humanos e consequentemente, na matéria fecal. Calcula-se que um ser humano adulto elimina de 50 a 400 bilhões desse tipo de bactéria por dia, (BRANCO et al. 1991). Dessa forma, sua presença permite detectar a presença de fezes na água em concentração extremamente diluídas, dificilmente verificáveis pelos métodos químicos utilizados. Porém, as bactérias patogênicas veiculadas por água estão sempre associadas as fezes, logo a presença de coliformes fecais constitui presença potencial de patogênicos. Assim sendo, a ausência de coliformes permite, sem dúvida, concluir pela ausência de matéria fecal.

As análises bacteriológicas realizadas no período de 1995 a 1996 pela CAERN, (tabelas 5.1 e anexo02), foram a partir de registros efetuados nos rios do Mudo, Guajiru lagoa de Extremoz e no rio Doce.

- No rio do Mudo, na Fazenda São Miguel, o valor máximo determinado para os coliformes fecais foi de $11000 \mathrm{NMP} / 100 \mathrm{ml}$ e um valor mínimo de $340 \mathrm{NMP} / 100 \mathrm{ml}$.

- No rio Guajiru na Fazenda Jardim, o valor máximo determinado foi de $2.200 \mathrm{NMP} / 100 \mathrm{ml}$ e um valor mínimo de $540 \mathrm{NMP} / 100 \mathrm{ml}$.

- Na Lagoa de Extremoz o valor máximo determinado foi de $300 \mathrm{NMP} / 100 \mathrm{ml}$ e um minimo de $27 \mathrm{NMP} / 100 \mathrm{ml}$.

- No rio Doce o valor máximo determinado foi de $11000 \mathrm{NMP} / 100 \mathrm{ml}$ e mínimo de 2.400

De acordo com a resolução n. ${ }^{\circ}$ 20/86 (CONAMA), os rios do Mudo e Guajiru no seu curso inferior, a lagoa de Extremoz e o rio Doce se enquadram na classe 1 . No que se refere a presença de coliformes fecais, foram estabelecidos, para essa classe, os seguintes limites e/ou condições: 
- as águas utilizadas para a irrigação ou plantas frutíferas que se desenvolvam rentes ao solo e que são consumidas cruas, sem remoção de casca ou película, não devem ser poluídas por excrementos humanos, ressaltando-se a necessidade de inspeções sanitárias periódicas. Para os demais usos, não deverá ser excedido um limite de 200 coliformes fecais por $100 \mathrm{ml}$ em $80 \%$ ou mais de pelo menos 5 amostras mensais colhidas em qualquer mês.

Para o uso de recreação de contato primário, (balneabilidade), as águas doces, salobras e salinas são avaliadas segundo as seguintes categorias:

a) Excelente: quando em $80 \%$ ou mais de um conjunto de amostras obtidas em cada uma das $S$ semanas anteriores, colhidas no mesmo local, houver no máximo, 250 coliformes fecais por $100 \mathrm{~mL}$ ou 1.200 coliformes totais por $100 \mathrm{ml}$.

b) Muito Boas: quando em $80 \%$ ou mais de um conjunto de amostras obtidas em cada uma das 5 semanas anteriores, colhidas no mesmo local, houver no máximo, 500 coliformes fecais por $100 \mathrm{ml}$ ou 2.500 coliformes totais por $100 \mathrm{ml}$.

c) Satisfatórias: quando em $80 \%$ ou mais de um conjunto de amostras obtidas em cada uma das 5 semanas anteriores, colhidas no mesmo local, houver no máximo, 1.000 coliformes fecais por $100 \mathrm{ml}$ ou 5.000 coliformes totais por $100 \mathrm{ml}$.

d) Impróprias: quando ocorrer, no trecho considerado, qualquer uma das seguintes circunstancias:

- não enquadramento em nenhuma das categorias anteriores, por terem ultrapassado os indices bacteriológicos nelas admitidos;

- ocorrência, na região, de incidência relativamente elevada ou anormal de enfermidades transmissiveis por via hídrica, a critério das autoridades sanitárias;

- sinais de poluição por esgotos, perceptíveis pelo olfato ou visão;

- recebimento regular, intermitente ou esporádico, de esgotos por intermédio de valas, corpos d'água ou canalizações, inclusive galerias de águas pluviais, mesmo que seja de forma diluída;

- presença de resíduos ou despejos, sólidos ou líquidos, inclusive óleos, graxas e outras substâncias, capazes de oferecer riscos à saúde ou tornar desagradável a recreação;

- $\mathrm{pH}$ menor que 5 ou maior que 8,5;

- presença na água, de parasitas que afetam o homem ou a constatação da existência de seus hospedeiros intermediários infectados; 
Tabela 5.1-Resumo dos resultados obtidos para alguns parâmetros físicos, químicos, biológicos e bacteriológicos no período de 1995 a 1996

\begin{tabular}{|c|c|c|c|c|c|c|c|c|c|c|c|c|c|c|}
\hline Localização & Valores & $\begin{array}{l}\text { Cor } \\
\left(\mathrm{u}^{\mathrm{B}_{3}}\right)\end{array}$ & $\begin{array}{l}\text { Turbidez } \\
\left(\mathrm{U}^{\mathrm{T}}\right)\end{array}$ & pII & $\begin{array}{c}\mathrm{STD} \\
(\mathrm{mg} / \mathrm{L})\end{array}$ & $\begin{array}{c}\mathrm{CT} \\
(\mathrm{mg} / \mathrm{L})\end{array}$ & $\begin{array}{c}\text { Alle. Total } \\
(\mathbf{m g} / \mathrm{L} \\
\left.\mathrm{CaCO}_{3}\right) \\
\end{array}$ & $\begin{array}{c}\mathrm{DT} \\
(\mathrm{mg} / \mathrm{L} \\
\left.\mathrm{CaCO}_{3}\right)\end{array}$ & $\begin{array}{c}\text { Mat. } \\
\text { Orgânica }\end{array}$ & $\begin{array}{c}\mathrm{OD} \\
(\mathrm{mg} / \mathrm{L})\end{array}$ & $\begin{array}{l}\mathrm{DBO}_{s} \\
(\mathrm{mg} / \mathrm{L})\end{array}$ & $\begin{array}{c}\mathrm{DQO} \\
(\mathrm{mg} / \mathrm{L})\end{array}$ & $\begin{array}{c}\mathrm{CT} \\
(\mathrm{mg} / \mathrm{L})\end{array}$ & $\begin{array}{c}\mathrm{CF} \\
(\mathrm{mg} / \mathrm{L})\end{array}$ \\
\hline $\begin{array}{l}\text { Rio do Mudo } \\
\text { (Br-406) }\end{array}$ & $\begin{array}{l}\text { VMAX } \\
\text { VMED } \\
\text { VMIN }\end{array}$ & $\begin{array}{l}75,0 \\
36,7 \\
7,0\end{array}$ & $\begin{array}{l}12,0 \\
6,1 \\
2,6\end{array}$ & $\begin{array}{l}7,5 \\
7,2 \\
6,5\end{array}$ & $\begin{array}{l}1.248,0 \\
589,8 \\
286,0\end{array}$ & $\begin{array}{l}116,0 \\
205,5 \\
120,0\end{array}$ & $\begin{array}{l}158,4 \\
126,1 \\
38,8\end{array}$ & $\begin{array}{l}363,0 \\
216,1 \\
65,0\end{array}$ & $\begin{array}{l}9,2 \\
5,1 \\
2,3\end{array}$ & $\begin{array}{l}7,0 \\
5,1 \\
3,8\end{array}$ & $\begin{array}{l}83,3 \\
7,7 \\
0,5\end{array}$ & $\begin{array}{l}168,0 \\
66,4 \\
1,7\end{array}$ & $\begin{array}{l}1.248,0 \\
589,8\end{array}$ & \\
\hline $\begin{array}{l}\text { Rio do Mudo } \\
\text { (Faz. S. Miguel) }\end{array}$ & $\begin{array}{l}\text { VMAX } \\
\text { VMED } \\
\text { VMIN }\end{array}$ & $\begin{array}{l}130,0 \\
46,1 \\
12,0\end{array}$ & $\begin{array}{l}9,5 \\
4,4 \\
1,1 \\
\end{array}$ & $\begin{array}{l}7,4 \\
6,9 \\
6,6\end{array}$ & $\begin{array}{l}1.462,0 \\
544,9 \\
362,0\end{array}$ & $\begin{array}{l}254,0 \\
166,4 \\
126,0\end{array}$ & $\begin{array}{l}92,4 \\
77,1 \\
55,0\end{array}$ & $\begin{array}{l}182,0 \\
137,1 \\
106,0\end{array}$ & $\begin{array}{l}9,6 \\
5,1 \\
2,1\end{array}$ & $\begin{array}{l}5,5 \\
4,0 \\
2,5\end{array}$ & $\begin{array}{l}46,3 \\
4,0 \\
0,3\end{array}$ & $\begin{array}{l}136 \\
62,8 \\
1,4\end{array}$ & $\begin{array}{l}50.000,0 \\
7.493,3 \\
1.600,00\end{array}$ & $\begin{array}{l}11.000 \\
1.589,3 \\
340\end{array}$ \\
\hline $\begin{array}{l}\text { Rio Guajiru } \\
(\mathrm{Br}-406)\end{array}$ & $\begin{array}{l}\text { VMAX } \\
\text { VMED } \\
\text { VMIN }\end{array}$ & $\begin{array}{l}110 \\
59,1 \\
22,0\end{array}$ & $\begin{array}{l}36,0 \\
8,7 \\
2,5\end{array}$ & $\begin{array}{l}7,5 \\
6,9 \\
6,5\end{array}$ & $\begin{array}{l}962,0 \\
414,0 \\
46,0\end{array}$ & $\begin{array}{l}322,0 \\
135,2 \\
79,0\end{array}$ & $\begin{array}{l}131,0 \\
59,8 \\
25,3\end{array}$ & $\begin{array}{l}267,0 \\
102,5 \\
56,0\end{array}$ & $\begin{array}{l}8,2 \\
5,3 \\
2,3\end{array}$ & $\begin{array}{l}6,6 \\
5,0 \\
3,3\end{array}$ & $\begin{array}{l}74,0 \\
6,2 \\
0,3\end{array}$ & $\begin{array}{l}184,0 \\
71,4 \\
0,8\end{array}$ & $\begin{array}{l}92.000,0 \\
12,092,9 \\
800\end{array}$ & \\
\hline (Faz. Jardim) & $\begin{array}{l}\text { VMED } \\
\text { VMIN }\end{array}$ & $\begin{array}{l}75,0 \\
42,9 \\
15,0 \\
\end{array}$ & $\begin{array}{l}4,3 \\
2,4 \\
1,0\end{array}$ & $\begin{array}{l}7,2 \\
6,8 \\
6,3 \\
\end{array}$ & $\begin{array}{l}540,0 \\
270,7 \\
178,0\end{array}$ & $\begin{array}{l}100,0 \\
74,8 \\
56,0 \\
\end{array}$ & $\begin{array}{l}57,7 \\
41,5 \\
26,4 \\
\end{array}$ & $\begin{array}{l}88,0 \\
61,5 \\
40,0\end{array}$ & $\begin{array}{l}9,1 \\
5,4 \\
2,0\end{array}$ & $\begin{array}{l}8,4 \\
3,8 \\
1,2\end{array}$ & $\begin{array}{l}37,0 \\
4,5 \\
0,4\end{array}$ & $\begin{array}{l}128,0 \\
79,0 \\
5,1\end{array}$ & $\begin{array}{l}5.000,0 \\
1.915,0 \\
170,0\end{array}$ & $\begin{array}{l}2.200,0 \\
349,1 \\
540,0\end{array}$ \\
\hline Rio Doce & $\begin{array}{l}\text { VMED } \\
\text { VMIN }\end{array}$ & $\left\{\begin{array}{l}55,0 \\
22,3 \\
7,0\end{array}\right.$ & $\begin{array}{l}6,4 \\
3,1 \\
1,5\end{array}$ & $\begin{array}{l}7,5 \\
6,7 \\
6,2\end{array}$ & $\begin{array}{l}692,0 \\
266,9 \\
120,0\end{array}$ & $\begin{array}{l}152,0 \\
70,2 \\
46,0\end{array}$ & $\begin{array}{l}144,0 \\
40,2 \\
25,2\end{array}$ & $\begin{array}{l}220,0 \\
65,2 \\
41,8\end{array}$ & $\begin{array}{l}7,1 \\
3,6 \\
2,3\end{array}$ & $\begin{array}{l}7,5 \\
5,6 \\
3,4\end{array}$ & $\begin{array}{l}83,3 \\
6,8 \\
0,4\end{array}$ & $\begin{array}{l}104,0 \\
42,2 \\
1,7\end{array}$ & $\begin{array}{l}90.000,0 \\
13.680,0 \\
200\end{array}$ & $\begin{array}{l}11.000,0 \\
1.723,1 \\
2.400\end{array}$ \\
\hline
\end{tabular}

Legenda: STD: Sólidos Totais Dissolvidos; Cl: cloreto Alc. Total: Alcalinidade Total; DT: Dureza Total; Mat. Orgânica: Matéria Orgânica;
OD: Oxigênio Dissolvido;

OD: Oxigênio Dissolvido; $\mathrm{DBO}_{5}$ : Demanda Bioquímica de Oxigênio a 5 dias; DQO: Demanda Química de oxigênio
CT: Coliformes Totais $\quad$ CF: Coliformes Fecais 
- presença nas águas doces de moluscos transmissores potenciais de esquistossomo, caso em que os avisos de interdição ou alerta deverão mencionar especificamente esse risco sanitário;

- outros fatores que contra-indiquem, temporariamente ou permanentemente, o exercício da recreação de contato primário.

No acompanhamento da condição das praias ou balneários as categorias Excelente, Muito Boas e Satisfatória poderão ser reunidas numa única categoria denominada Própria.

Conforme as condições e/ou limites estabelecidos em relação a presença de coliformes fecais, (Resolução n. ${ }^{\circ}$ 20/86 CONAMA), as águas da lagoa de Extremoz foram classificadas como sendo muito boas para a prática da recreatividade. No entanto, a presença de moluscos transmissores de esquistossomo, restringe o uso desse manancial para o exercício da recreação de contato primário. As águas do rio do Mudo, na localidade de São Miguel e do rio Guajiru, na localidade de Jardim, foram classificadas como impróprias para a balneabilidade, quando analisados os valores máximos de coliformes fecais.

\subsection{2 - Parâmetros medidos em Campo - Novembro/99}

Os parâmetros obtidos a partir das medições em campo, $(\mathrm{pH}$, Condutividade Elétrica e Sólidos Totais Dissolvidos), (tabela 5.2), permitiram configurar zoneamentos para os corpos de águas superficiais, na bacia, conforme pode ser visto na figura 5.5. Os zoneamentos restringiram-se aos cursos médio e inferior da bacia, devido ao fato de que os
rios são perenes apenas nesses trechos.

Os valores obtidos para o pH, (figura 5.5a), mostra que no médio curso da bacia, tanto o rio do Mudo quanto o rio Guajiru apresentaram pH entre 7,0 e 7,5. Uma faixa de valores entre 6,5 e 7,0, foi verificada para as águas do curso inferior dos rios Guajiru e Doce. As medições na lagoa de Extremoz indicaram uma faixa de valores entre 6,5 a 7,4.

PEREIRA (1993) quando investigou o índice de qualidade da água da Lagoa de Extremoz, no período de janeiro/92 a janeiro/93, constatou valores para o $\mathrm{pH}$ entre 7,4 a 8,3. ARAÚJO (1997) ao estudar a variação anual da comunidade fitopanctônica neste corpo d'água, no período de janeiro/96 a janeiro/97, encontrou valores que variaram de 6,9 a 8,8 .

DUARTE (1999) realizou campanhas de amostragens, no periodo de 1996 a 1997 e verificou que os valores médios de pH se apresentaram na faixa de 6,3 a 8,4 .

Para a condutividade elétrica, (figura 5.5b) foi caracterizado o seguinte 
comportamento: no curso inferior da bacia foram obtidos valores entre 300 a $500 \mu \mathrm{S} / \mathrm{cm}$, no médio curso, valores entre 500 a $1000 \mu \mathrm{S} / \mathrm{cm}$ e em direção a montante valores entre 1000 a $2000 \mu \mathrm{S} / \mathrm{cm}$.

Tabela 5.2 - Medições obtidas em campo, Novembro/98

\begin{tabular}{|c|c|c|c|c|c|c|}
\hline \multirow[t]{2}{*}{ Localidade } & \multicolumn{2}{|c|}{ Coordenadas } & \multirow[t]{2}{*}{ Município } & \multirow[t]{2}{*}{ pH } & $\begin{array}{c}\text { Cond. } \\
(\mu \mathrm{s} / \mathrm{cm})\end{array}$ & $\begin{array}{c}\mathrm{STD} \\
(\mathrm{mg} / \mathrm{L}) \\
\end{array}$ \\
\hline & $\mathrm{X}$ & $Y$ & & & & \\
\hline Lagoa de Extremoz- Henrique Gaspar & 246.70 & $9.365,50$ & Extremoz & 7.4 & 400,0 & 193 \\
\hline Rio Doce - Descarga da Lagoa & 247.40 & $9.368,90$ & Extremoz & 7,5 & 424,0 & 209 \\
\hline Lagoa de Extremoz-Ponta Grossa & 241.453 & $9.368,82$ & Extremoz & 7,4 & 500,0 & 283 \\
\hline Rio do Mudo - Comum & 238.30 & $9.369,00$ & Extremoz & 7,4 & 550 & 263 \\
\hline Rio do Mudo -. Ponte Br- C. Mirim & 238.50 & $9,366,30$ & São Gonçalo & 7,9 & 717 & 344 \\
\hline Rio do Mudo & 231.216 & $9,374,421$ & Ceará Mirim & 7,6 & 1.862 & 920 \\
\hline Rio Mudo - Jacoca de Baixo & 229.058 & $9.373,265$ & Ceará Mirim & 7.5 & 3.270 & 1.690 \\
\hline Rio Guajira & 242.423 & 9.365 .659 & S. Gonçalo & 6,6 & 313 & 180 \\
\hline Rio Guajin & 228,601 & 9.373 .606 & S. Gonçalo & 7,6 & 5.190 & 2.690 \\
\hline Rio Guajiru & 235,198 & 9.365 .529 & S. Gonçalo & 7,5 & 770 & 366 \\
\hline Barramento D. Bosco & 233,405 & 9.365 .166 & S. Gonçalo & 7,0 & 715 & 342 \\
\hline Riacho & 226.849 & 9.364 .399 & Ielmo Marinho & 7,2 & 1.210 & 580 \\
\hline
\end{tabular}

Estudos realizados, especificamente na lagoa de Extremoz, por ARAÚJO (1997), caracterizaram uma variação entre 300 e $382 \mu \mathrm{S} / \mathrm{cm}$. DUARTE (1999) verificou uma faixa de valores entre 303 a $446 \mu \mathrm{S} / \mathrm{cm}$, duas vezes mais elevados que os valores determinados na lagoa do Bonfim localizada a sul de Natal e estudada no mesmo período. A comparação entre estas duas lagoas, evidencia que os diferentes tipos de rochas que constituem os terrenos onde estão inseridos os respectivos corpos d'água influi fortemente neste parâmetro físico da água. No caso da lagoa de Extremoz, esta possui dois rios afluentes, carreando ao longo do seu percurso elevadas concentrações de $\mathrm{Ca}, \mathrm{Mg}, \mathrm{Na}$ e $\mathrm{Cl}$, provenientes das rochas cristalinas e calcárias existentes no alto curso da bacia.

As medições dos Sólidos Totais Dissolvidos, (figura $5.5 \mathrm{c}$ ) indicaram duas faixas de valores: para as águas do curso inferior da bacia, os sólidos totais dissolvidos apresentaram valores entre 200 a $500 \mathrm{mg} / \mathrm{L}$; no médio curso as concentrações são da ordem de 500 a $1000 \mathrm{mg} / \mathrm{L}$ (STD) de modo que, nos locais onde afloram as rochas cristalinas estas concentrações atingiram valores acima de $1000 \mathrm{mg} / \mathrm{L}$.

Ao comparar os respectivos resultados com os valores médios obtidos pela CAERN, no período de 1995 a 1996, (item 5.1.1.2, tabela 5.1), verifica-se que encontram-se em um mesmo intervalo. 


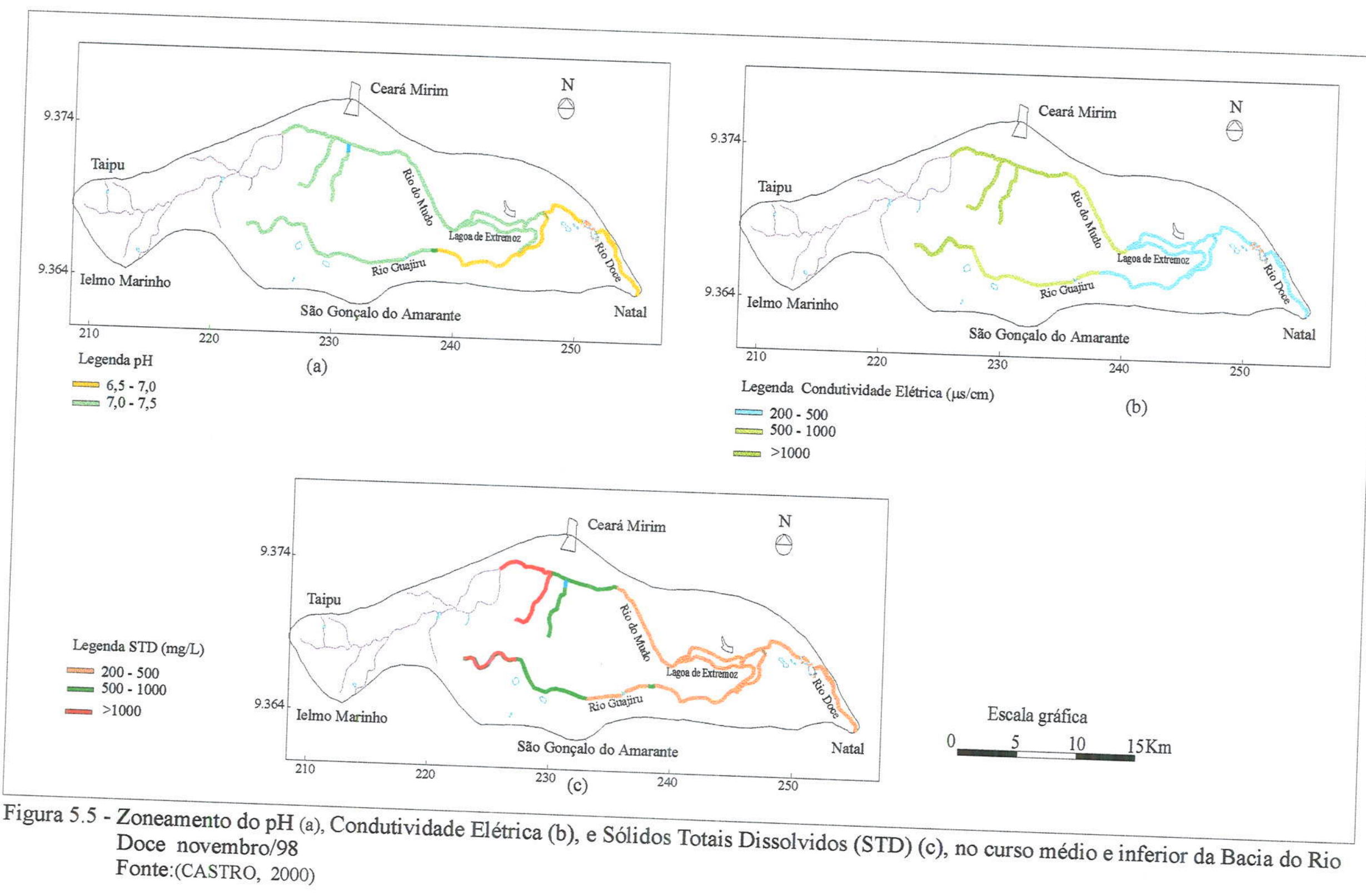


A elevada condutividade elétrica e as altas concentrações dos sólidos totais dissolvidos verificados em direção à montante da bacia, além de estarem associados ao tipo litológico das rochas (cristalinas e calcárias), também estão fortemente relacionadas as baixas precipitações e às altas taxas de evaporação. SOUZA \& MOTA (1994) indicam que entre os fatores determinantes da salinização, estão o clima, as condições de circulação da água e a natureza do terreno e que o principal processo que controla a salinização pode ser considerado de origem climática, tendo em vista, que as águas parecem adquitir a sua composição química a partir da concentração progressiva por evaporação.

FENZL (1988) cita que os fatores climáticos tais como precipitação, evapotranspiração e variações de temperatura influem consideravelmente sobre o quimismo das águas superficiais e subterrâneas mediante processos de diluição, concentração ou aumento da solubilidade. De modo que, de uma certa forma, o quimismo das águas naturais reflete as condições climáticas de uma região. Em regiões secas, os solos e as zonas subsaturadas não sofrem lixiviações importantes, permitindo a acumulação de determinados sais, que chegam aos corpos d'água superficiais e aos aqüiferos de forma irregular, quando ocorrem as grandes chuvas.

SANTIAGO (1984) desenvolveu estudos em dois reservatórios no estado do Ceará, em regiões de terrenos cristalinos e concluiu que com a ocorrência das primeiras chuvas os corpos aquáticos recebem uma massa significativa de sais provenientes da lixiviação do solo. Se as primeiras precipitações são muito intensas, o aumento da massa de sais é rápida gerando para os corpos de águas superficiais até 2,8 toneladas de cloretos por $\mathrm{km}^{2}$ de bacia.

\section{1 .3 - Recorte para Lagoa de Extremoz - Índices de Qualidade da Água (IQA) e do Estado Trófico (IET) e Potabilidade}

DUARTE (1999) desenvolveu estudos objetivando a análise da variação espaçotemporal das características tróficas e sanitárias da lagoa de Extremoz, através dos Índices de Qualidade da Água (IQA) e do Estado Trófico (IET). As amostragens, para esses estudos foram realizadas em três pontos na lagoa $(E 1, E 2, E 3)$, conforme indicado na figura 5.6.

O Índice de Qualidade da Água (IQA), é resultante de uma equação matemática que se baseia em valores de vários parâmetros de qualidade, quanto aos aspectos físicos, químicos e biológicos. 


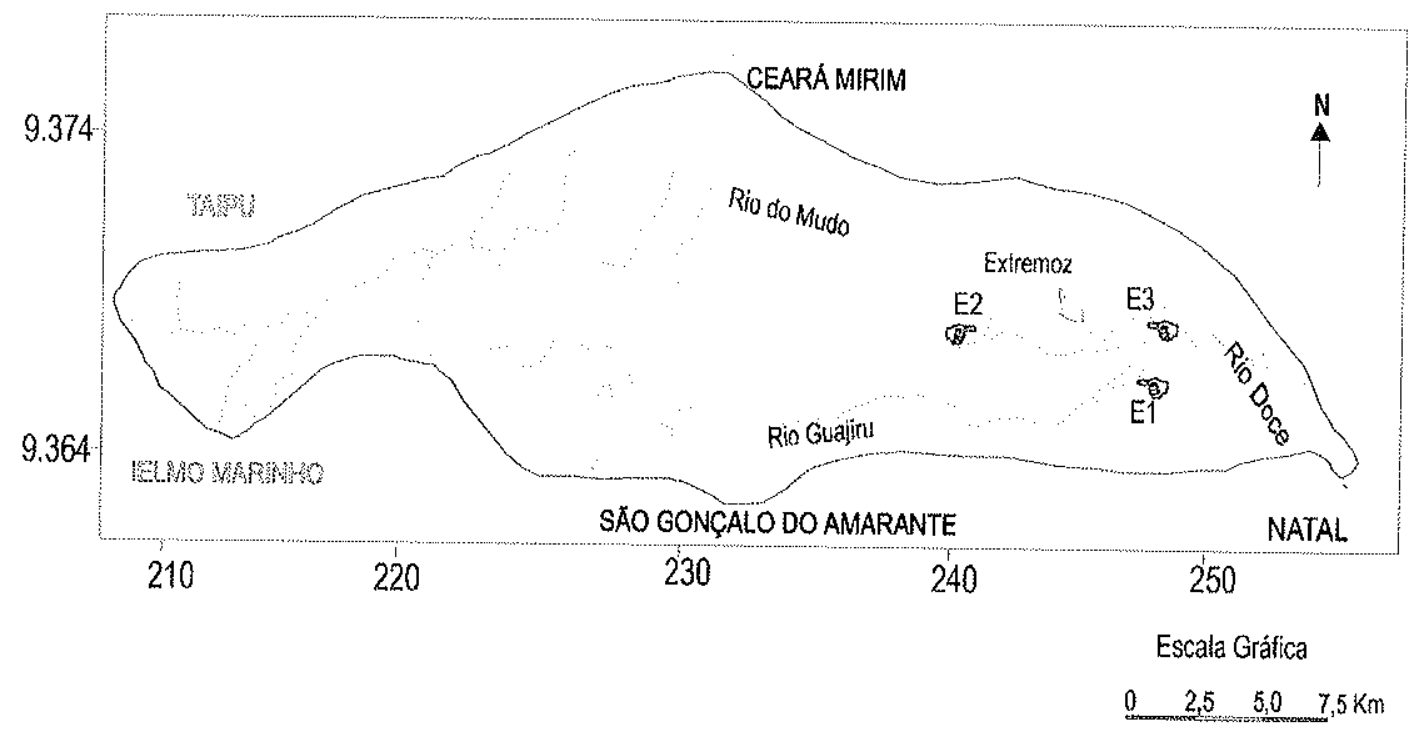

Figura 5.6 - Locais onde foram efetuadas as amostragens para avaliação do IQA Fonte: (DUARTE, 1999)

Para a sua aplicação utiliza-se nove parâmetros e para cada um deles existe um peso de acordo com a sua importância na determinação do índice. A tabela.5.3, apresenta os respectivos parâmetros:

Tabela 5.3 - Parâmetros e pesos para cálculo do IQA

\begin{tabular}{|l|l|l|}
\hline Parâmetro & Unidade & Peso \\
\hline Oxigênio Dissolvido (OD) & \% saturação & 0,17 \\
Coliformes Fecais (CF) & NMP/lo0ml & 0,15 \\
PH & - & 0,12 \\
DBO5 & $\mathrm{mg} \mathrm{O}_{2} / \mathrm{L}$ & 0,10 \\
Nitrogênio Total (NT) & $\mathrm{mg} \mathrm{N} / \mathrm{L}$ & 0,10 \\
Fósforo Total (PT) & $\mathrm{mg} \mathrm{P/L}$ & 0,10 \\
Turbidez (TUR) & uT & 0,08 \\
Sólidos Totais (ST) & $\mathrm{mg} / \mathrm{L}$ & 0,08 \\
Temperatura de Desvio (AT) & ${ }^{\circ} \mathrm{C}$ & 0,10 \\
\hline
\end{tabular}

Fonte: (DUARTE, 1999)

O IQA pode ser calculado através de duas expressões matemáticas que definem o IQA aditivo $\left(I_{A}\right)$ e o IQA multiplicativo $\left(\operatorname{IQA}_{M}\right)$ :

$$
\begin{aligned}
& \operatorname{IQA}_{A}={ }_{\mathrm{I}=1}^{9} \mathrm{qi}^{*} \mathrm{Wi} \\
& \mathrm{IQA}_{\mathrm{M}}={ }^{9} \prod_{\mathrm{I}=1} \mathrm{i}^{\mathrm{Wi}}
\end{aligned}
$$

Onde: 

contínua de 0 a 100.

IQA = índice de Qualidade de água, representado por um número em escala entre 0 e 100.

$q \mathrm{i}=$ qualidade individual (subíndice de qualidade) do iésimo parâmetro, um valor

$\mathrm{Wi}=$ peso unitário do iésimo parâmetro.

indice.

A tabela. 5.4, mostra a classificação da água de acordo com o valor atribuído ao

Tabela 5.4 - Classificação de águas naturais, conforme o IQA

\begin{tabular}{|l|l|}
\hline Indice (IQA) & Qualidade \\
\hline $80-120$ & Otima \\
$52-79$ & Boa \\
$37-51$ & Aceitável \\
$20-36$ & Imprópria para tratamento \\
$0-19$ & $\begin{array}{l}\text { convencional } \\
\text { Imprópria para consumo } \\
\end{array}$ \\
& humano \\
\hline
\end{tabular}

Fonte: (GUAZZELLI \& OTTA, 1979)

Nestes estudos foram constatados que os Índices de Qualidade de Água (aditivo e multiplicativo) apresentaram variações relativamente pequenas entre os pontos analisados, variando de 63 no ponto E1 a 85 no ponto E2, (tabela 5.5). Ambos os métodos empregados classificaram o corpo aquático de qualidade entre boa e ótima.

A eutrofização, "doença dos lagos" é considerada como um incremento da produção autrófica de matéria orgânica particulada e dissolvida, em lagos e reservatórios, devido ao aumento de nutrientes essenciais para o fitoplâncton e macrófitas aquáticas. Denota um processo natural ou artificial de nutrientes aos corpos d'água e os efeitos resultantes dessa adição. A eutrofização é assim parte do processo natural de envelhecimento dos lagos que ocorreria independentemente das atividades do homem, (NOGUEIRA, 1991).

DUARTE (1999) ressalta que o Índice do Estado Trófico (IET), não somente classifica um corpo aquático, como também serve para verificar sobre as relações entre os vários parâmetros de um ecossistema aquático. $O$ autor utilizou três parâmetros (transparência, fósforo total e clorofila "a"), para a classificação da lagoa de Extremoz quanto ao grau de eutrofização, cujos índices determinados encontram-se na tabela 5.5 .

Os índices de qualidade da água (aditivo e multiplicativo) apresentaram variações relativamente pequenas entre os pontos E1, E2 e E3, O menor valor do IQA aditivo foi determinado em E1 (68), em maio/97 e o maior em E2 (85), em julho do mesmo ano. O IQA multiplicativo teve comportamento semelhante, com o menor valor em El (63), em abril/97 e o máximo, de 85, em E2, no mês de setembro/97. Ambos classificam a água do manancial 
como de qualidade entre boa e ótima. Os estudos desenvolvidos por PERElRA (1993) em dois pontos do manancial indicaram que o IQA aditivo classificou-a como ótima enquanto o multiplicativo considerou-a boa .

Tabela 5.5 - Índice de qualidade da água (aditivo e multiplicativo) da lagoa de Extremoz/RN (período de dezembro/96 a dezembro/97)

\begin{tabular}{|c|c|c|c|c|c|c|c|c|c|c|}
\hline Més & & & $\begin{array}{c}\text { IQA } \\
\text { aditivo }\end{array}$ & & & & $\begin{array}{c}\text { IQA } \\
\text { muttiplicativo }\end{array}$ & \\
\hline & $E 1$ & $E 2$ & $E 3$ & Médio & Classificação & $E 1$ & $E 2$ & $E 3$ & Médio & Classificação \\
\hline Dez & 83 & 80 & 74 & 79 & Boa & 81 & 79 & 70 & 77 & Boa \\
\hline Jan & 78 & 79 & 74 & 77 & Boa & 77 & 78 & 68 & 75 & Boa \\
\hline Fev & 71 & 76 & 75 & 74 & Boa & 68 & 71 & 72 & 71 & Boa \\
\hline Mar & 78 & 79 & 76 & 77 & Boa & 77 & 77 & 73 & 76 & Boa \\
\hline Abr & 70 & 79 & 75 & 74 & Boa & 63 & 75 & 70 & 69 & Boa \\
\hline Mai & 68 & 79 & 82 & 76 & Boa & 64 & 73 & 80 & 74 & Boa \\
\hline Jun & 79 & 80 & 81 & 80 & Ótima & 77 & 77 & 78 & 77 & Boa \\
\hline Jul & 76 & 85 & 80 & 80 & Otima & 74 & 84 & 77 & 79 & Boa \\
\hline Ago & 81 & 81 & 82 & 81 & Otima & 80 & 78 & 80 & 79 & Otima \\
\hline Set & 83 & 86 & 81 & 83 & Ótima & 82 & 85 & 80 & 82 & Otima \\
\hline Out & 78 & 81 & 82 & 80 & Otima & 76 & 78 & 80 & 78 & Boa \\
\hline Nov & 79 & 80 & 80 & 80 & Otima & 76 & 77 & 77 & 77 & Boa \\
\hline Dez & 82 & 79 & 79 & 80 & Ótima & 79 & 76 & 75 & 77 & Boa \\
\hline
\end{tabular}

Fonte: (DUARTE, 1999)

A figura 5.7, mostra as escassas flutuações desses dois índices assim como a semelhança de qualidade entre os locais pesquisados. As variações isoladas de um parâmetro não foram suficientes para refletirem-se no índice final. O IQA, em particular a versão aditiva, que envolve muitos parâmetros, apresenta aparentemente menor sensibilidade, quando a qualidade da água encontra-se em níveis mais altos. Com efeito, o IQA tem como finalidade principal a classificação de um determinado corpo aquático no que diz respeito à qualidade sanitária e físico-química de uma água para consumo humano.

O autor constatou que a condição de oligotrofia só foi observada no mês de fevereiro/97 no ponto E2, para a clorofila " $a$ ".

As caracteristicas mesotrópicas foram verificadas nos meses de estiagem em fevereiro/97 e a partir de agosto até dezembro/97 para os três parâmetros. Os pontos E1 e E2 foram os que apresentaram maior freqüûncia de condições mesotróficas. Nos meses de março, abril, maio e junho/97, prevaleceram as condições eutróficas em todos os pontos. 

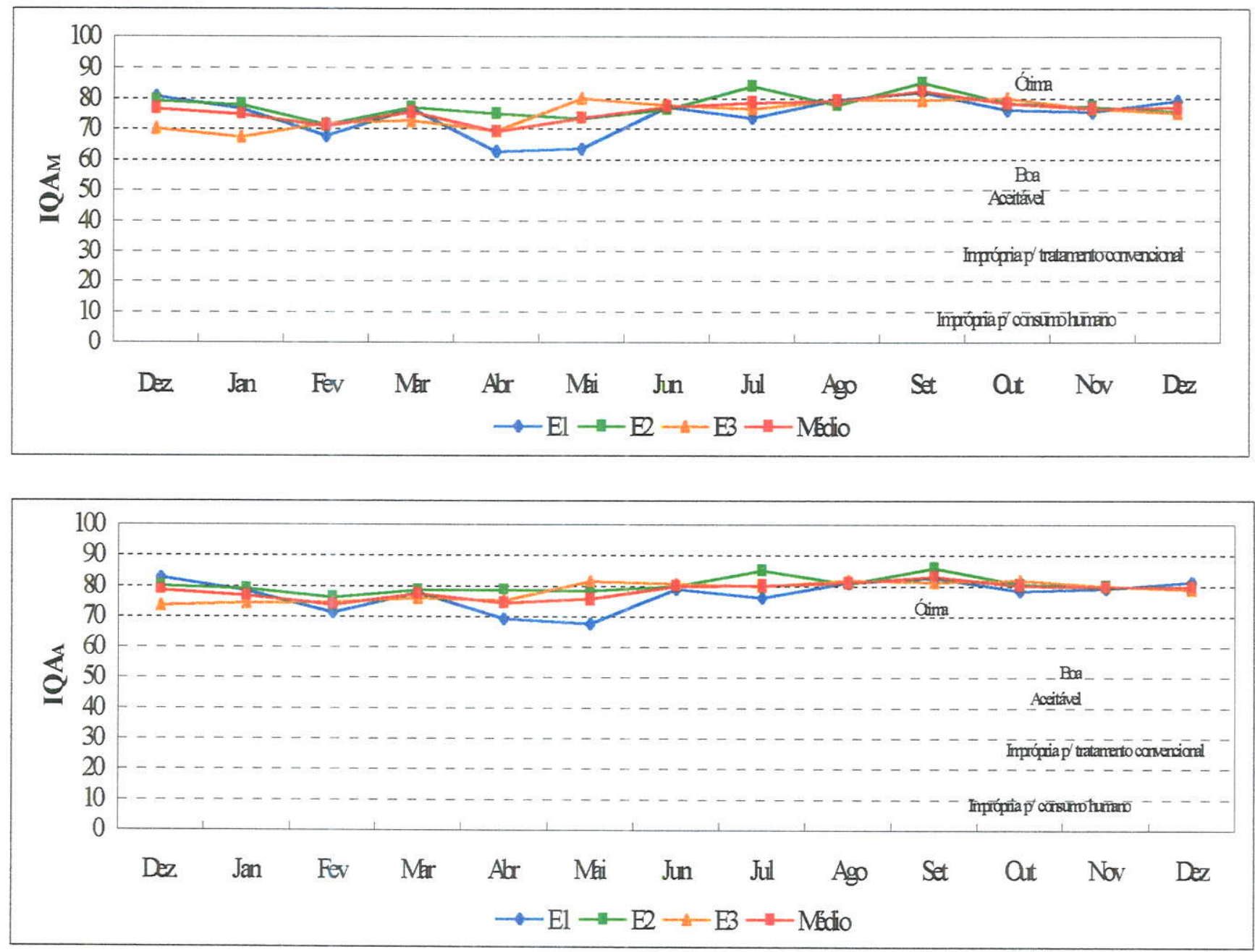

Figura 5.7- Variação espaço-temporal do IQAA e IQAM, na lagoa de Extremoz-RN (dez/96 a dez/97) Fonte: (DUARTE, 1999) 
$\mathrm{O}$ autor conclui que esse comportamento possivelmente está associado as maiores descargas de fósforo, visto que são nestes meses que concentram-se as maiores precipitações na bacia hidrográfica, consequentemente promovendo um crescimento da biomassa algal, estimulada pelo aporte exógeno de nutrientes. Foi efetuada uma comparação dos valores obtidos para os índices tróficos tradicional e modificado e foi constatado que o IET classifica o manancial da lagoa de Extremoz como eutrófico com tendência para a hipereutrofia, enquanto o $\mathrm{IET}_{\mathrm{M}}$, (Índice do Estado Trófico Modificado), define a Lagoa como mesotrófica em oito ocasiões e como eutrófica em apenas três meses.

Ao Comparar os resultados obtidos por PEREIRA (1993) e DUARTE (1999) foi constatado que a qualidade sanitária da lagoa de Extremoz manteve-se inalterada no período de 1993 a 1999.

\subsubsection{1- Potabilidade}

As águas da lagoa de Extremoz foram caracterizadas com Potabilidade predominantemente Boa, os teores dos Cátions, Ânions e outros parâmetros físicos e químicos, estão resumidos na tabela 5.6, que podem ser comparados aos limites estabelecidos pela Organização Mundial de Saúde e pela Portaria do Ministério da Saúde No 36 de 19/01 1990.

\section{2 - Águas Subterrâneas - Sistema Aqüífero Dunas/Barreiras}

\subsection{1 - Caracterização Iônica}

Os resultados das análises químicas das águas, foram tratados através do programa Acquaquem - Hydrogeological - Watherterloo, onde os cátions e os ânions foram plotados nos diagramas triangular de PIPER e Stiff, o que permitiu a identificação das fácies hidroquímicas e dos íons dominantes.

A classificação das águas através dos íons dominantes, (tabela 5.7 e figuras 5.8 , 5.9), mostrou que as águas captadas do sistema aqüifero Dunas/Barreiras são predominantemente cloretadas sódicas e naqueles pontos onde os poços ou cacimbões atingiram as rochas carbonáticas, como por exemplo, (P188 e C194), as águas se classificam como sendo bicarbonatadas sódicas ou cálcicas. 
Tabela 5.6 - Padrões de Potabilidade das águas e valores determinados

\begin{tabular}{|c|c|c|c|c|c|c|}
\hline \multirow[t]{2}{*}{ Características } & \multicolumn{2}{|c|}{$\begin{array}{c}\text { Valore Obtidos } \\
\text { Lagoa de Extremoz } \\
\text { (Abril/98) }\end{array}$} & \multicolumn{2}{|c|}{$\begin{array}{c}\text { Valores Obtidos } \\
\text { Águas Subterrâneas } \\
\text { (Aqüifero } \\
\text { Barreiras/Novembro/97) }\end{array}$} & \multirow[t]{2}{*}{$\begin{array}{c}\text { Portaria No. } 36 \\
\text { de } 19 / 01 / 90\end{array}$} & \multirow[t]{2}{*}{$\begin{array}{l}\text { OMS } \\
\text { (VMP) }\end{array}$} \\
\hline & Valor mínimo & Valor máximo & Valor mínimo & Valor máximo & & \\
\hline I - Físicas e organolépticas & & & & & & \\
\hline Turbidez $\left(\mathrm{u}^{\mathrm{T}}\right)$ & 0,35 & 1,14 & & & 1 & 5 \\
\hline Cor & 7,5 & 12,5 & & & 5 & 5 \\
\hline Odor & Inobjetável & Inobjetável & Inobjetável & Inobjetável & Inobjetável & Inobjetável \\
\hline Sabor & Inobjetável & Inobjetável & Inobjetável & Inobjetável & Inobjetável & Inobjetável \\
\hline Sólidos Totais Dissolvidos & & & 40 & 195 & 1000 & 1000 \\
\hline $\mathrm{I}-$ Químicos & & & & & & \\
\hline Dureza total (mg/L $\left.\mathrm{CaCO}_{3}\right)$ & 74,30 & 109,39 & 3,43 & 71,49 & 500 & 500 \\
\hline Cloretos $(\mathrm{mg} / \mathrm{L} \mathrm{Cl})$ & 81,42 & 101,7 & 10,43 & 94,77 & 250 & 500 \\
\hline Sulfatos ( $\left.\mathrm{mg} / \mathrm{L} \mathrm{SO}_{4}\right)$ & 2,46 & 10,46 & 0,35 & 9,84 & 400 & 200 \\
\hline Cálcio $\left(\mathrm{mg} / \mathrm{L} \mathrm{Ca}^{+-}\right)$ & 11,16 & 21,07 & 0,39 & 20,16 & - & 200 \\
\hline Magnésio (mg/L $\mathrm{Mg}^{+}$) & 11,28 & 13,79 & 0,47 & 6,23 & - & 200 \\
\hline Nitrato $\left(\mathrm{mg}^{\mathrm{L}} \mathrm{NO}_{3}\right)$ & 0,31 & 2,30 & 0,1 & 55,09 & - & 45 \\
\hline Ferro (mg/L Fe) & 0,33 & 0,49 & 0,08 & 1,15 & 0,3 & 0,3 \\
\hline
\end{tabular}

OMS - Organização Mundial de Saúde

VMP - Valores Máximos Permissiveis 
A montante da bacia onde as coberturas arenosas são de menores espessuras e sofre maior influência das rochas cristalinas foi verificada um tipo cloretada cálcica, (C260).

A concentração do sódio nas rochas sedimentares é de $3.870 \mathrm{mg} / \mathrm{kg}$, nas rochas argilosas de $4.850 \mathrm{mg} / \mathrm{kg}$ e nas rochas carbonáticas de $393 \mathrm{mg} / \mathrm{kg}$. Durante o intemperismo e os processos de troca iônica $\left(\mathrm{Na}^{+}\right.$, por $\left.\mathrm{Ca}^{++}\right)$, grandes quantidades de sódio podem ser liberadas nas águas subterrâneas.

De acordo com estudos realizados pelo IPT (1982), as águas de chuva da região da "Grande Natal" são do tipo cloretadas-sódicas, o que é perfeitamente justificável, devido à influência do mar através dos aerossóis, cujos íons dominantes são o ânion cloreto e o cátion sódio.

De acordo com LOYD \& HEATHCOTE (1985) (apud FENZL, 1988), as águas subterrâneas com dominância de bicarbonatos e cálcio, freqüentemente indicam águas de recarga em arenitos e calcários, enquanto as águas com cloreto e sódio dominantes indicam águas de circulação profunda ou de zonas de descarga.

Tabela 5.7-Resumo dos tipos de classificações iônicas obtidas

\begin{tabular}{|c|c|c|c|c|c|}
\hline ID & Localizacão & & & Ions Dominantes & Classificaccão \\
\hline $\mathrm{P} 43$ & Granja Santana & 248,502 & 9.369 .610 & $\mathrm{Cl}-\mathrm{Na}-\mathrm{Mg}$ & Cloretada Sódica \\
\hline P51 & Distrito Industrial & 247.338 & $9.367,816$ & $\mathrm{Cl}-\mathrm{Na}-\mathrm{HCO}_{3}$ & Cloretada Sódica \\
\hline $\mathrm{P} 68$ & Distrito Industrial & 246,667 & $9.364,189$ & $\mathrm{Cl}-\mathrm{Na}-\mathrm{SO}_{4}$ & Cloretada Sódica \\
\hline P7I & Laguna Hotel & 246,592 & $9.368,610$ & $\mathrm{HCO}_{3}-\mathrm{Ca}-\mathrm{Cl}$ & Bicarbonatada Cálcica \\
\hline $\mathrm{P76}$ & Distrito Industrial & 246,539 & $9.365,770$ & $\mathrm{Cl}-\mathrm{Na}-\mathrm{HCO}_{3}$ & Cloretada Sódica \\
\hline P87 & Distrito Industrial & 246,430 & $9.365,600$ & $\mathrm{Cl}-\mathrm{Na}-\mathrm{Ca}$ & Cloretada Sódica \\
\hline $\mathrm{P} 101$ & Distrito Industrial & 246,151 & $9.365,142$ & $\mathrm{Cl}-\mathrm{Na}-\mathrm{HCO}_{3}$ & Cloretada Sódica \\
\hline $\mathrm{P} 136$ & Granja Wengrid & 243,901 & 9.370 .191 & $\mathrm{Cl}-\mathrm{Na}-\mathrm{Mg}$ & Cloretada Sódica \\
\hline $\mathrm{C} 175$ & Fazenda Xingu & 239,881 & $9.365,669$ & $\mathrm{HCO}_{3}-\mathrm{Ca}-\mathrm{Cl}$ & Bicarbonatada Cálcica \\
\hline P188 & Maçaranduba & 238,330 & $9.365,735$ & $\mathrm{HCO}_{3}-\mathrm{Na}-\mathrm{Cl}$ & Bicarbonatada Sódica \\
\hline $\mathrm{P194}$ & Maçaranduba & 237,394 & $9.367,648$ & $\mathrm{HCO}_{3}-\mathrm{Na}-\mathrm{Cl}$ & Bicarbonatada Cálcica \\
\hline $\mathrm{P} 202$ & Maçaranduba & 237,052 & $9.365,605$ & $\mathrm{Cl}-\mathrm{Mg}-\mathrm{Ca}$ & Cloretada Magnesiana \\
\hline $\mathrm{P} 213$ & Granja São Pedro & 233.625 & $9.363,638$ & $\mathrm{Cl}-\mathrm{Na}-\mathrm{HCO}_{3}$ & Cloretada Sódica \\
\hline $\mathrm{C} 260$ & Canto de Moça & 226,186 & $9.365,55 \mathrm{l}$ & $\mathrm{Cl}-\mathrm{Na}-\mathrm{Ca}-\mathrm{HCO}_{3}$ & Cloretada Cálcica \\
\hline $\mathrm{P} 36$ & Centro dos Idosos & 249,969 & $9.366,008$ & $\mathrm{Cl}-\mathrm{Na}-\mathrm{Mg}$ & Cloretada Sódica \\
\hline P158 & Parque 6 irmãos & 242,149 & $9.364,142$ & $\mathrm{Cl}-\mathrm{Na}-\mathrm{HCO}_{3}$ & Cloretada Sódica \\
\hline
\end{tabular}

\section{2 .2 - Potabilidade}

As águas subterrâneas (sistema aqüifero Dunas/Barreiras), foram caracterizadas com Potabilidade predominantemente Boa. Os teores dos Cátions, Ânions e outros parâmetros físicos e químicos, estão resumidos na tabela 5.6, (item 5.1.3.1), que podem ser comparados aos limites estabelecidos pela Organização Mundial de Saúde e pela Portaria do Ministério da Saúde N. ${ }^{\circ} 36$ de 19/0I 1990. 


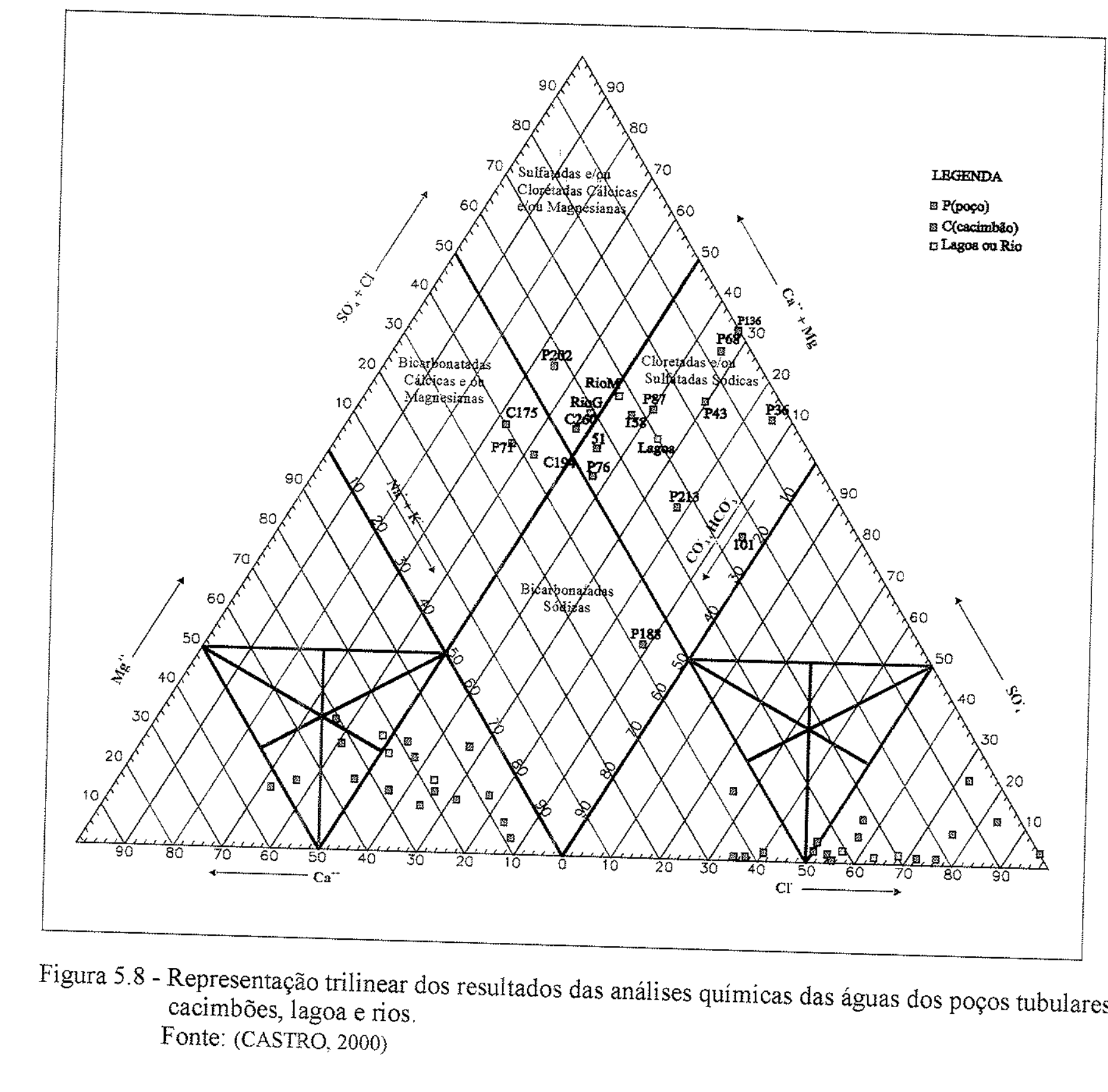




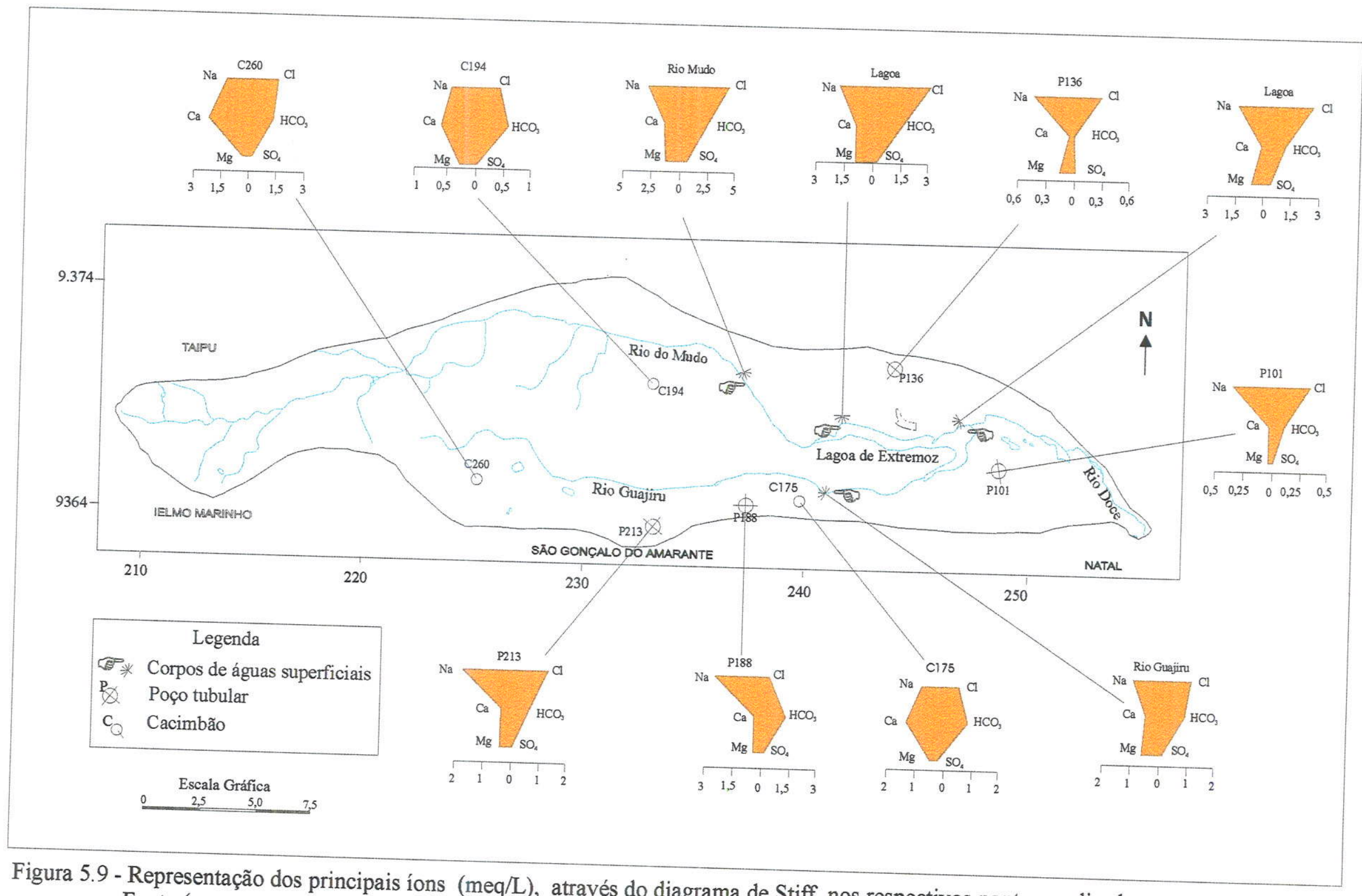
Fonte:(CASTRO, 2000) 
Dentre os parâmetros químicos analisados e comparados com os valores estabelecidos pelo Ministério da Saúde e pela Organização Mundial de Saúde (OMS), tabela 5.6, (item 5.1.3.1), apenas o nitrato $\left(\mathrm{NO}_{3}^{-}\right)$e o ferro ( $\mathrm{Fe}$ ), apresentaram teores com valores acima dos limites estabelecidos. Os teores mais elevados de nitrato ocorreram no cacimbão 260 e no poço P71, cujas concentrações foram de $55,09 \mathrm{mg} / \mathrm{L} \mathrm{e} 44,85 \mathrm{mg} / \mathrm{L}$ respectivamente. Os teores mais elevados de ferro ocorreram em três poços da Indústria Vicunha com $0,73 \mathrm{mg} / \mathrm{L}, 0,97 \mathrm{mg} / \mathrm{L}$ e $1,15 \mathrm{mg} / \mathrm{L}$ (Fe).

\subsection{3 - Nitrato}

O nitrogênio, na forma de nitrato, é um dos contaminantes mais comuns identificados nas águas subterrâneas. Ocorre principalmente na atmosfera, nos solos e em substâncias orgânicas. Nas precipitações pluviométricas a concentração de nitrogênio na forma de amônio $\left(\mathrm{NH}_{4}{ }^{+}\right)$, varia de 0,01 a $1,00 \mathrm{mg} / \mathrm{L}$, e os teores de nitrato $\left(\mathrm{NO}_{3}{ }^{-}\right)$estão na faixa de 0,30 a $2,50 \mathrm{mg} / \mathrm{L}$, podendo atingir até 12,00 $\mathrm{mg} / \mathrm{L}$ (SCHOELLER, 1962).

No meio ambiente a matéria orgânica pode sofrer várias mudanças, fornecendo desde amina $\left(\mathrm{R}_{-} \mathrm{NH}_{2}\right)$, evoluindo para amônia $\left(\mathrm{NH}_{3}\right)$, amônio $\left(\mathrm{NH}_{4}{ }^{+}\right)$, nitrito $\left(\mathrm{NO}_{2}{ }^{2}\right)$ e , finalmente, atingindo a forma mais estável e oxidada do nitrogênio, o nitrato $\left(\mathrm{NO}_{3}{ }^{-}\right)$. Este processo é chamado de nitrificação e processa-se mediante as reações:

$$
\begin{aligned}
& 2 \mathrm{NH}_{4}^{+}+2 \mathrm{OH}^{-}+3 \mathrm{O}_{2}^{-} \quad 2 \mathrm{NO}_{2}^{-}+4 \mathrm{H}_{2} \mathrm{O} \\
& 2 \mathrm{NO}_{2}^{-}+\mathrm{O}_{2} 2 \mathrm{NO}_{3}^{-}
\end{aligned}
$$

Em condições favoráveis este processo é reversível, passando a ser denominado de desnitrificação, (figura 5.10).

A matéria orgânica existente nos esgotos e nos resíduos vegetais produzem amoníaco ou o ín amônio através do processo de decomposição e mediante a participação de bactérias especializadas, de acordo com a reação:

$$
\mathrm{CH}_{2} \mathrm{O}\left(\mathrm{NH}_{3}\right)+\mathrm{O}_{2} \leftrightarrow \mathrm{NH}_{4}^{+}+\mathrm{HCO}_{3}^{-}
$$

O ín amônio $\left(\mathrm{NH}_{4}^{+}\right)$ou o amoníaco $\left(\mathrm{NH}_{3}\right)$ formam-se sob a condição do $\mathrm{pH}$ da água, obedecendo à seguinte reação:

$$
\mathrm{NH}^{+}+\mathrm{OH}^{-} \mathrm{NH}_{3} . \mathrm{H}_{2} \mathrm{O}
$$

Se o pH da água diminui, a reação produz $\mathrm{NH}_{4}{ }_{4}$, caso contrário produz $\mathrm{NH}_{3}$. A conversão do nitrogênio orgânico para $\mathrm{NH}_{4}^{+}$é conhecido como amonificação. A amonifícação e nitrificação são processos que normalmente ocorrem na zona insaturada, na zona do solo, 
onde a matéria orgânica e o oxigênio são abundantes, (FREEZE et. al. 1979) e (KOMOR et. al. 1993).

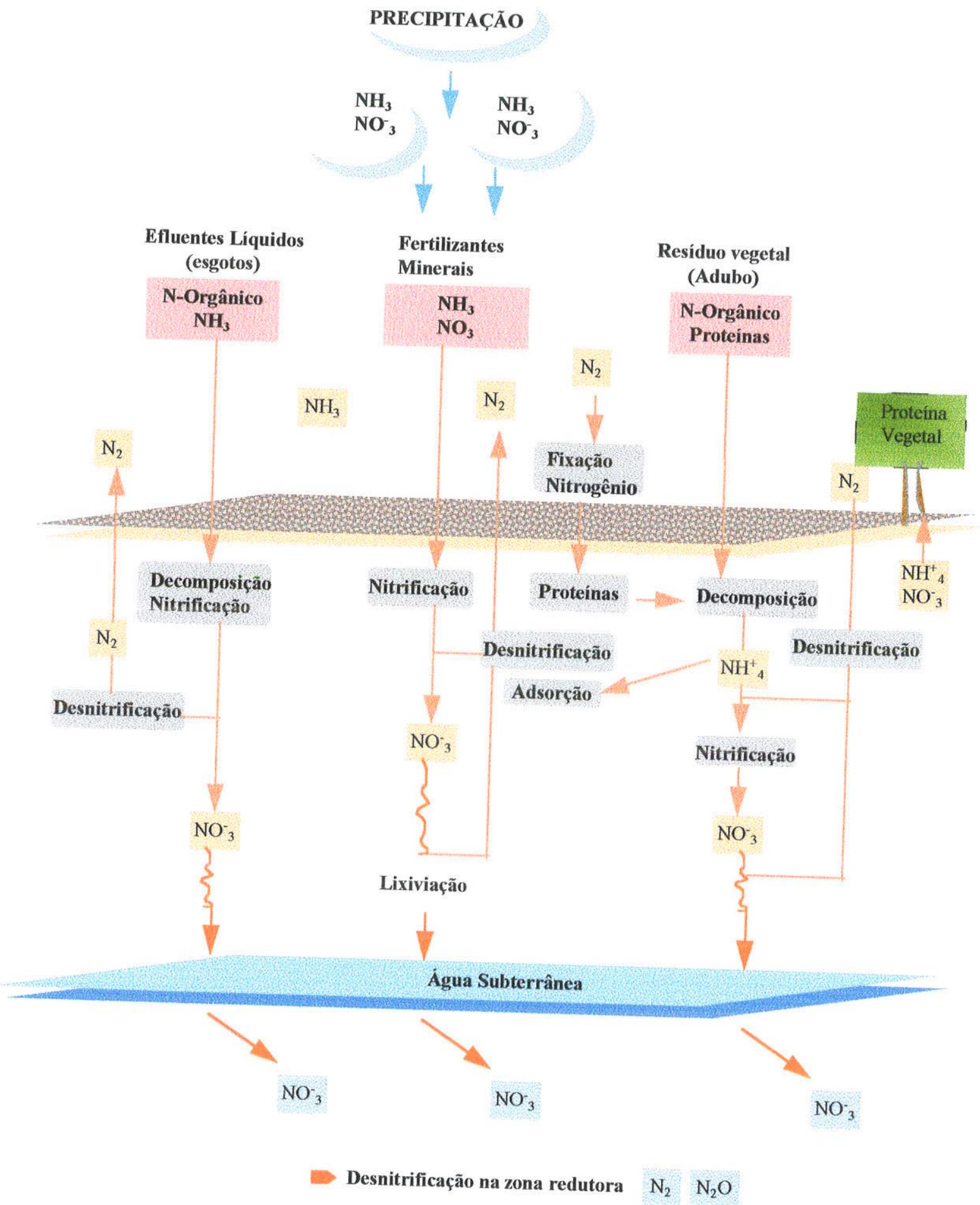

Figura 5.10 - Fontes e caminhos do nitrogênio no ambiente sub-superficial Fonte: (FREEZE et al. 1979) 
MELO (1995) realizou estudos sobre os impactos do desenvolvimento urbano nas águas subterrâneas de Natal, salientando como o mais impactante o sistema de saneamento com disposição local de efluentes domésticos (fossas e sumidouros), sendo o principal tipo de contaminante envolvido o ion nitrato, resultado provavelmente da biodegradação dos excrementos humanos. A contaminação é favorecida pela vulnerabilidade atribuída às condições geomorfológicas e estrutura hidrogeológica caracterizada pela existência do capeamento de areias de dunas, pela formação de depressões ou bacias fechadas, pela ocorrência de lagoas e sobretudo pela conexão hidráulica das dunas com os sedimentos Barreiras.

Estudos recentes, realizados por MELO (1998), compreendendo uma área nas proximidades da lagoa de Extremoz, (figura 5.11), identificou no domínio da captação d'água Pajuçara/Gramoré, Sistema Público de Abastecimento da Zona Norte de Natal, teores de nitrato elevado, chegando a $80 \mathrm{mg} / \mathrm{L}$, superior aos padrões recomendados pela Organização Mundial de Saúde que é de no máximo $45 \mathrm{mg} / \mathrm{L}$.

A figura 5.11 apresenta as áreas com contaminações pontuais de nitrato nas águas subterrâneas da área estudada, obtidas a partir de análises quimicas realizadas no ano de 1997. Os teores de nitrato crescem a partir de um nivel geral de base de $10 \mathrm{mg} / \mathrm{L}$ na parte leste da área, em direção aos conjuntos habitacionais da zona norte de Natal, e na parte oeste, onde concentram-se cacimbões de profundidades médias de 14 metros de profundidade nas localidades de Canto de Moça e Ponte do Mato.

Atualmente na Indústria Guararapes Têxtil, foi observada uma evolução dos teores de nitrato no período dez/96 a outubro/98 conforme pode ser visto na figura 5.12 .

Na unidade industrial da Parmalat, também foi constatado uma evolução nos teores de nitrato, cloreto e condutividade elétrica, (figura 5.13).

CASTRO (1994) realizou estudos na zona leste de Natal, no bairro de Cidade Nova, e identificou teores de nitrato acima de $45,0 \mathrm{mg} / \mathrm{L}$, alguns pontos analisados mostraram uma expressiva evolução das concentrações. Houve pontos, por exemplo, que aumentaram de 21,0 a $105 \mathrm{mg} / \mathrm{L}$ e de 8,52 a $31,58 \mathrm{mg} / \mathrm{L}$ no período de 1987 a 1993.

Essa evolução pode ser explicada devido à forma anionica, propiciando uma alta mobilidade do nitrato na água subterrânea. Em aqüíferos pouco profundos e constituídos por sedimentos permeáveis, ou em zonas fraturadas, onde existe $\left(\mathrm{O}_{2}\right)$ dissolvido, o nitrato geralmente migra para grandes distancias a partir das zonas de origem, sem sofrer processos de retardamento, como adsorsão por exemplo, (FREEZE et al. 1979). 


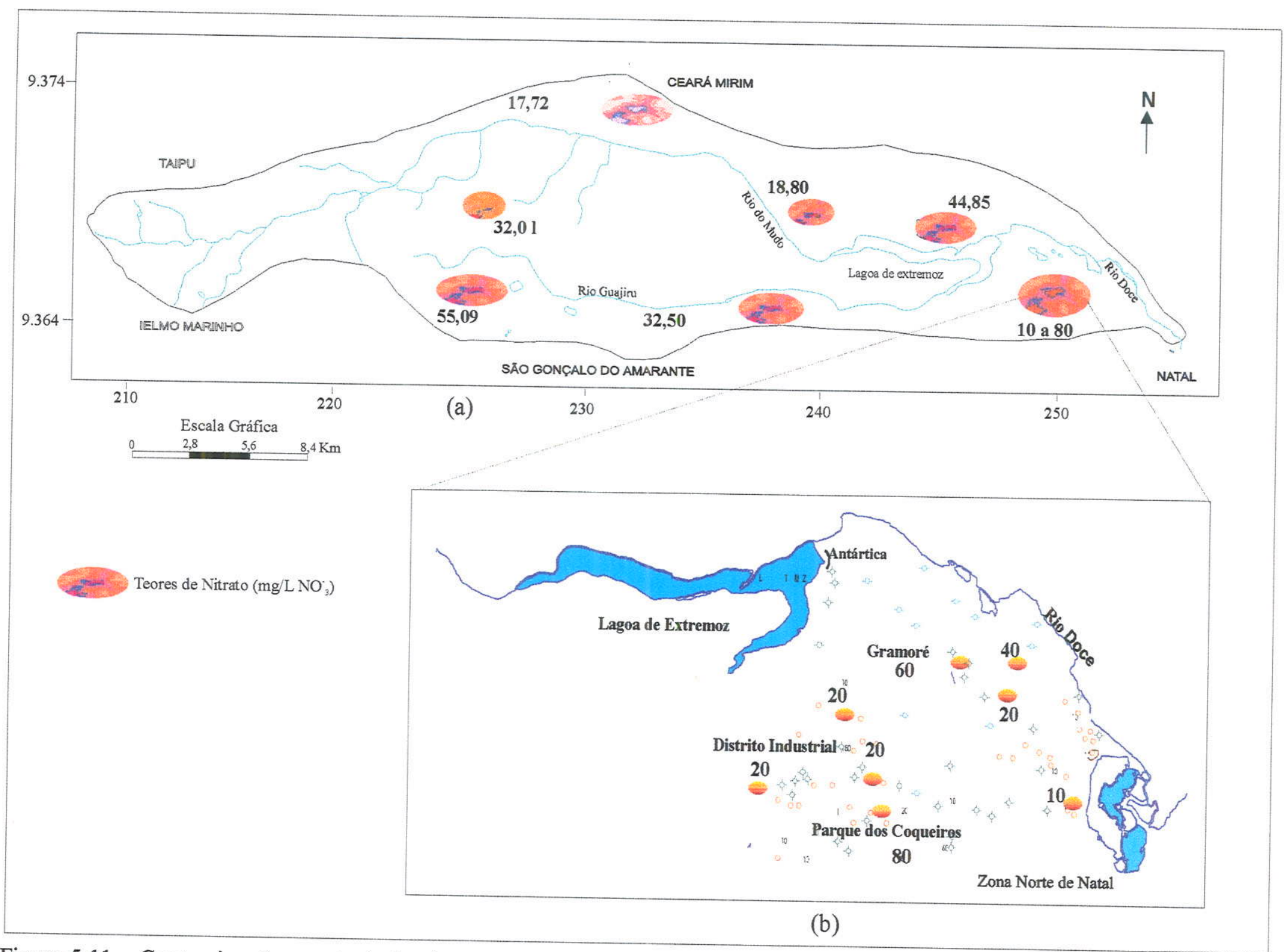

Figura 5.11 - Contaminações pontuais de nitrato na Bacia do Rio Doce (a) e na Zona Norte de Natal (b)
Fonte:(CASTRO, 2000) 


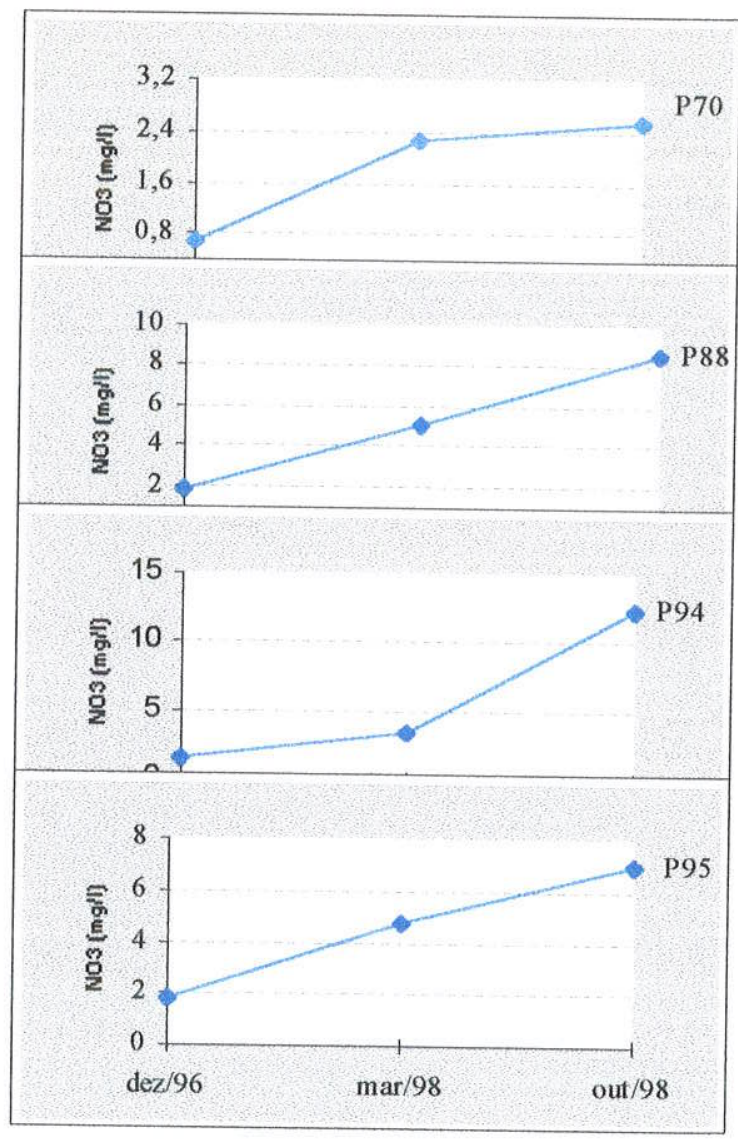

Figura 5.12 - Evolução dos teores de nitrato na Indústria Guararapes Têxtil Fonte: (CASTRO, 2000)

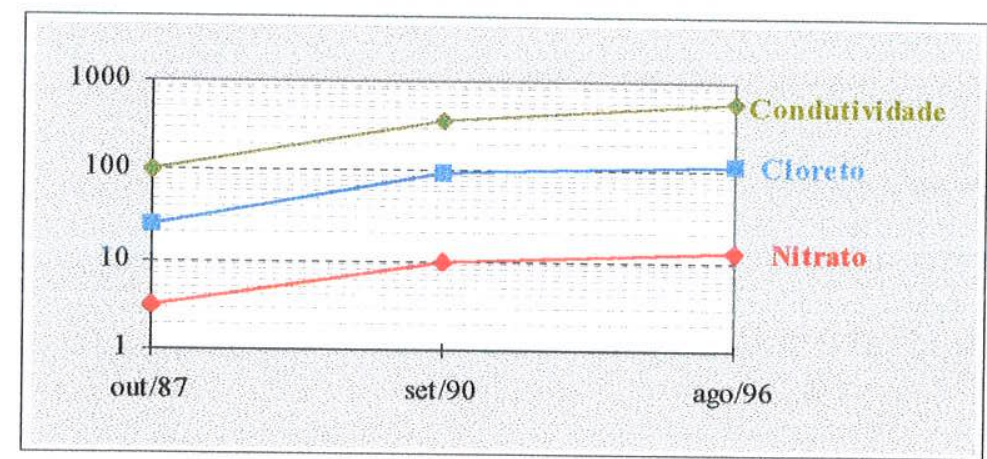

Figura 5.13 - Comportamento da condutividade, cloreto e nitrato no período de 1987 a 1996 na indústria Parmalat

Fonte: (CASTRO, 2000)

Os estudos realizados por CASTRO (1994) e MELO (1995 e 1998), constataram que o nitrogênio ocorre nas águas subterrâneas, na sua forma mais estável que é o nitrato. O amônio e o nitrito são pouco representados. Concluíram também que existe uma correlação 
entre a densidade populacional e o nivel de nitrato nas águas subterrâneas da grande Natal. Nas zonas mais habitadas, os teores de nitrato tendem a ser mais elevados, atingindo níveis inadequados de utilização (superiores a $45 \mathrm{mg} / \mathrm{L}$ ). A contaminação também está associada ao tempo de implantação e funcionamento das atividades urbanas. A tabela 5.8 apresenta os teores de nitrato nos poços tubulares e cacimbões, novembro/97.

Tabela - 5.8 - Resumo dos pontos d'água com os respectivos teores de $\mathrm{NO}_{3}^{\circ}$, novembro/97

\begin{tabular}{|l|r|r|r|}
\hline & \multicolumn{2}{|c|}{ COORDENADAS } & \multicolumn{1}{c|}{$\mathbf{N O}_{3}$} \\
\hline IDENT. & \multicolumn{1}{|c|}{$\mathbf{X}$} & \multicolumn{1}{c|}{$\mathbf{Y}$} & $\mathbf{( m g / L )}$ \\
\hline P24 & 251,166 & $9,366,524$ & 16,00 \\
\hline P28 & 250,736 & $9.366,124$ & 5,00 \\
\hline P36 & 249,969 & $9.366,008$ & 8,57 \\
\hline P59 & 247,045 & $9.364,362$ & 1,10 \\
\hline P71 & 246,592 & $9.368,610$ & 44,85 \\
\hline P74 & 246,571 & $9.366,370$ & 3,80 \\
\hline P82 & 246,443 & $9.365,300$ & 0,80 \\
\hline P88 & 246,319 & $9.365,484$ & 8,52 \\
\hline P87 & 246,430 & $9.365,600$ & 1,40 \\
\hline P94 & 246,253 & $9.365,530$ & 12,32 \\
\hline P101 & 246,151 & $9.365,142$ & 0,50 \\
\hline P103 & 246,097 & $9.366,180$ & 1,10 \\
\hline P136 & 243,901 & $9.370,455$ & 18,80 \\
\hline P188 & 238,330 & $9.365,735$ & 0,00 \\
\hline P202 & 237,052 & $9.365,605$ & 32,50 \\
\hline P213 & 233,625 & $9.363,638$ & 0,45 \\
\hline P221 & 231,092 & $9.374,534$ & 17,72 \\
\hline C260 & 226,186 & $9.365,551$ & 55,09 \\
\hline C175 & 239,881 & $9.365,669$ & 18,80 \\
\hline C194 & 237,394 & $9.367,648$ & 11,84 \\
\hline P80 & 246,471 & $9.363,929$ & 0,1 \\
\hline P56 & 247,148 & $9.363,815$ & 0,0 \\
\hline P68 & 246,667 & $9.364,189$ & 1,5 \\
\hline P66 & 246,717 & $9.363,864$ & 0,2 \\
\hline P53 & 247,218 & $9.364,264$ & 0,6 \\
\hline P34 & 250,333 & $9.365,502$ & 15,0 \\
\hline P29 & 250,641 & $9.363,929$ & 2,4 \\
\hline F0nte: & & \\
\hline
\end{tabular}

Fonte: (CASTRO 2000)

\subsection{4 - Parâmetros Medidos em Campo - Novembro/97}

Os parâmetros obtidos a partir de uma campanha de medições em campo de $\mathrm{pH}$, Condutividade Elétrica, e Sólidos Totais Dissolvidos, (tabela 5.9), permitiram configurar zoneamentos para estes elementos nas águas subterrâneas, conforme pode ser visto na figura 5.14. 
Tabela 5.9 - Resumo dos parâmetros medidos em campo

\begin{tabular}{|c|c|c|c|c|c|}
\hline Localidade & Município & $\mathrm{pH}$ & $\begin{array}{c}\text { Condutividade } \\
(\mu \mathrm{s} / \mathrm{cm})\end{array}$ & $\begin{array}{c}\text { STD } \\
(\mathrm{mg} / \mathrm{l}) \\
\end{array}$ & $\begin{array}{c}\text { Sais } \\
\%\end{array}$ \\
\hline P58 & Extremoz & 5,4 & 56,8 & 26 & 0,0 \\
\hline P64 & Extremoz. & 6,3 & 94.2 & 44,0 & 0,0 \\
\hline P69 & Extremo\% & 4.7 & 287 & 140 & 0,1 \\
\hline $\mathrm{PlOl}$ & Extremoz & 5.9 & 124,4 & 59 & 0.1 \\
\hline $\mathrm{P} 103$ & Extremoz & 6.9 & 126 & 59 & 0,1 \\
\hline $\mathrm{Pl24}$ & Extremoz & 5,6 & 73.2 & 34 & 0,0 \\
\hline $\mathrm{P} 132$ & Extremoz & 5,9 & 137,3 & 64,4 & 0,1 \\
\hline $\mathrm{P} 136$ & Extremoz & 5,2 & 61,5 & 29 & 0,0 \\
\hline P177 & Extremoz & 5,5 & 450 & 215 & 0,2 \\
\hline P188 & S. Gonçalo & 7.8 & 336 & 160 & 0,2 \\
\hline P209 & S. Gonçalo & 7,6 & 1278 & 621 & 0,6 \\
\hline $\mathrm{P} 213$ & S. Gonçalo & 7,1 & 253 & 138 & 0,1 \\
\hline $\mathrm{P215}$ & S. Gonçalo & 5,5 & 856 & 413 & 0.4 \\
\hline $\mathrm{P} 227$ & S. Gonçalo & 5,2 & 290 & 139 & 0,1 \\
\hline P228 & S. Gonçalo & 6,1 & 522 & 248 & 0.2 \\
\hline $\mathrm{P231}$ & Ceará Mirim & 8,5 & 678 & 323 & 0.3 \\
\hline $\mathrm{P} 238$ & Ceará Mirim & 8.2 & 471 & 222 & 0,2 \\
\hline $\mathrm{C} 67$ & Extremoz & 5,2 & 131,4 & 62 & 0.1 \\
\hline $\mathrm{ClO6}$ & Extremoz & 5,1 & 175,1 & 82 & 0.1 \\
\hline C148 & Extremoz & 6,3 & 52 & 25 & 0,0 \\
\hline C186 & \begin{tabular}{|l|} 
Extremoz \\
\end{tabular} & 5,3 & 711 & 343 & 0.3 \\
\hline $\mathrm{Cl} 94$ & S. Gonçalo & 5,8 & 174,3 & 80 & 0,1 \\
\hline $\mathrm{C} 237$ & S. Gonçalo & 5,5 & 299 & 142 & 0,1 \\
\hline $\mathrm{P} 239$ & Ceará Mirim & 8,0 & 759 & 367 & 0,4 \\
\hline $\mathrm{C} 248$ & Lelmo Marinho & 6.6 & 146,6 & 69 & 0.1 \\
\hline $\mathrm{C} 251$ & Ceará Mirim & 6,5 & 2110 & 1050 & 1,1 \\
\hline $\mathrm{C} 256$ & Ceará Mirim & 5,3 & 90.3 & 42 & 0,0 \\
\hline $\mathrm{C} 260$ & Ielmo Marinho & 6,2 & 313 & 150 & 0.1 \\
\hline Granja Sta. Angela estr. Estivas & Extremoz & 6,9 & 158 & 77 & 0,1 \\
\hline Mangabeiras & Extremoz & 5,5 & 45 & 20 & 0,0 \\
\hline Granja Malvina - Manoel Fernandes & Extremoz & 5,4 & 98,3 & 46 & 0,0 \\
\hline Faz Santa Maria & Ceará Mirim & 5,8 & 121,8 & 57 & 0,1 \\
\hline Cacimbão- Floricultura -Rio Guajiru & Extremoz & 6,0 & 544 & 262 & 0,3 \\
\hline Carão -- Poço FNS & Extremoz & 5,7 & 128,3 & 61 & 0,0 \\
\hline Poço-SAAE - Ponta Grossa & Extremoz & 6,5 & 292 & 123 & 0,1 \\
\hline Poço - CDM - Ponta Grossa & Extremoz & 7,0 & 208 & 98 & 0,1 \\
\hline Poço SAAE-Murici & Extremoz & 5,7 & 48 & 22 & 0,0 \\
\hline
\end{tabular}

O comportamento do $\mathbf{p H}$, indica que no curso inferior da bacia, no extremo leste, o mesmo varia entre 4,7 a 6,4. Nesta área as águas subterrâneas são captadas exclusivamente do aqüífero Barreiras e nos poços onde foram realizadas as medições, os respectivos perfís construtivos mostram isolamento do contato entre o arenito da formação Barreiras e as rochas carbonáticas que aparecem na base dos perfis. No médio e alto curso da bacia, onde as fontes 
de águas subterrâneas compreendem arenitos e rochas carbonáticas, o pH apresenta valores entre 5,2 a 7,8 , (figura $5,14 a$ ).

No curso inferior da bacia, foi verificado que existem duas faixas de valores para a Condutividade Elétrica, de modo que no extremo leste da área foram obtidos valores na faixa de $50 \mu . \mathrm{s} / \mathrm{cm}$ a $100 \mu \mathrm{s} / \mathrm{cm}$ e no trecho seguinte, as medições indicaram, valores entre $150 \mu \mathrm{s} / \mathrm{cm}$ a $500 \mu \mathrm{s} / \mathrm{cm}$, conforme mostra a figura $5.14(\mathrm{~b})$. No médio curso foi caracterizado um intervalo de $500 \mu \mathrm{s} / \mathrm{cm}$ a $700 \mu \mathrm{s} / \mathrm{cm}$, e no alto curso os valores medidos para a condutividade elétrica foram da ordem de 700 a $1000 \mu \mathrm{s} / \mathrm{cm}$.

Quanto aos Sólidos Totais Dissolvidos (STD), foram identificadas três faixas de zoneamento, (figura 5.14c). No curso inferior da bacia os valores ficaram compreendidos entre $50 \mathrm{mg} / \mathrm{L}$ a $250 \mathrm{mg} / \mathrm{L}$, no médio curso as medições variaram entre $300 \mathrm{mg} / \mathrm{L}$ a $450 \mathrm{mg} / \mathrm{L}$ e no alto curso os valores foram maiores que $450 \mathrm{mg} / \mathrm{L}$.

\section{0 - USO E OCUPAÇÃO DO SOLO E FONTES POTENCIAIS DE CONTAMINAÇÃo}

\section{1 - Uso e Ocupação do Solo}

A qualidade da água está intimamente relacionada à proteção dos recursos hídricos, que por sua vez depende, da forma do uso e ocupação do solo na bacia hidrográfica. Em geral uma bacia hidrográfica tomada como unidade de planejamento envolve mais de um município e parte do território de um Estado, tornando-se necessário um planejamento regional. Quando se trata do uso da água de uma unidade hidrográfica, imediatamente conduz ao uso e ocupação do solo e o planejamento passa a envolver o próprio processo de desenvolvimento da região.

A história da civilização, no que se refere à ocupação geográfica, está sempre relacionada à presença da água. As grandes cidades e zonas de ocupação ocorrem ao longo dos rios e vales, devido às necessidades de abastecimento de água para uso humano, navegação e irrigação.

No início deste século, quando as densidades demográficas e industriais eram baixas, as demandas eram muito pequenas e a qualidade da água para consumo era protegida pela desapropriação integral da bacia e manutenção de sua condição natural. Mas dentro deste contexto sempre existiu um agravante, que o próprio uso exige, a alteração dessa condição natural. Caso a manutenção das condições estritamente naturais do corpo d'água constituísse condição do uso múltiplo racional, seria inviável qualquer utilização do solo e qualquer obra de regularização para permitir o próprio uso múltiplo. 


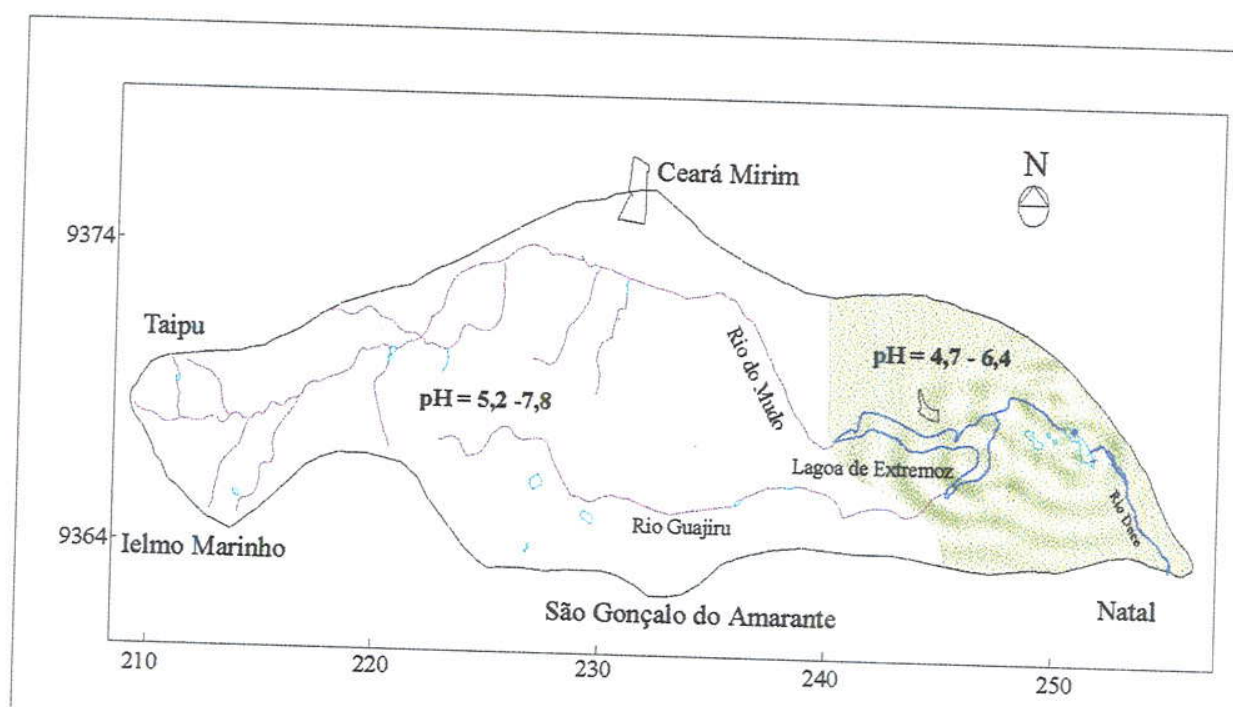

(a)

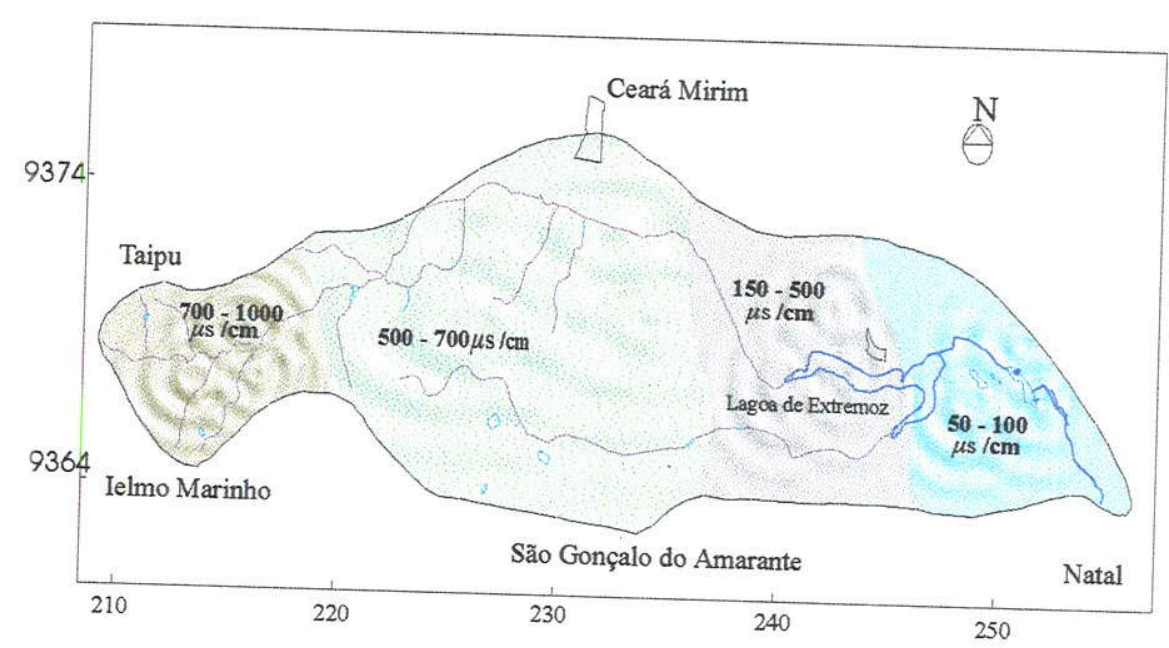

(b)

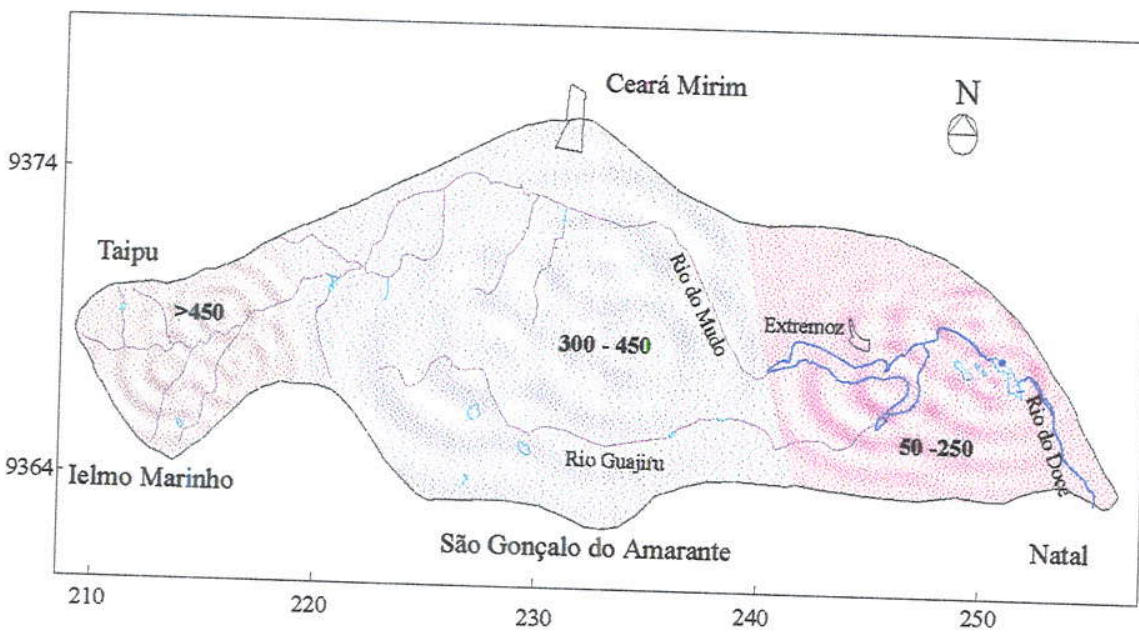

Escala gráfica

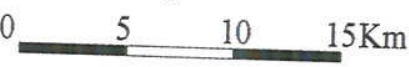

Figura 5.14 - Zoneamento do $\mathrm{pH}$ (a), Condutividade Elétrica (b), e Sólidos Totais Dissolvidos (STD) (c), nas águas subterrâneas da Bacia do Rio
Doce novembro/98 Fonte: (CASTRO, 2000) 
Dessa forma, constata-se que a condição natural não constitui o principal requisito para um adequado uso múltiplo, e sim quando assegurado por um rigoroso planejamento, fundamentado no conhecimento das potencialidades dos recursos hídricos, das características geográficas, das condições sócio-econômicas e necessidades atuais e futuras da região.

O modelo de gerenciamento do solo versus recursos hídricos nas bacias hidrográficas, induz a um entendimento no qual está implícito de que as águas de montante devem ser preservadas e as de jusante serão poluídas, gerando o conceito de que o desenvolvimento industrial é sinônimo de poluição das águas.

A experiência brasileira tem demonstrado as dificuldades para aplicação das medidas preventivas visando à proteção dos recursos hídricos através do uso adequado do solo. Estas medidas têm sido fortemente questionadas e repelidas pelos proprietários de terra na bacia, ou pelo próprio poder público, que não dispõe de outras áreas para expansão do seu município, para realização de seus planos habitacionais e crescimento geral.

No entanto, é inevitável a presença do Estado, de forma atuante e articulador de todo o processo, uma vez que as forças do mercado ainda não conduziram às soluções adequadas aos problemas do setor. É preciso que o Estado planeje e controle o uso do patrimônio público para que o processo econômico aconteça com o máximo de beneficios e o mínimo de custos para a população como um todo.

A adequação entre o processo de urbanização/crescimento populacional, e a utilização dos recursos hídricos adquire caráter de urgência na maior parte das grandes cidades do mundo, marcados pelo acelerado e desordenado processo de ocupação da terra.

A bacia hidrográfica em estudo, apesar de ser uma das menores, entre as dezesseis bacias que o Estado possui, mostra-se bastante diversificada nos aspectos climáticos, geomorfológicos, hidrogeológicos e consequentemente no uso e ocupação do solo. Portanto, para uma melhor compreensão deste comportamento, fez-se uma caracterização das atividades do uso e ocupação da terra, contemplando três trechos na bacia. A figura 6.1 representa o mapa de uso e ocupação do solo da bacia do Rio Doce elaborado a partir de imagens de satélites tipo Spot-2 em escala 1:50.000, ano 1994 e com reambulação de campo. As figuras 6.2 e 6.3 constituem uma visão parcial, através de fotografias aéreas realizadas em outubro de 1998.

No primeiro trecho, onde nascem os rios Guajiru e do Mudo, as atividades do uso do solo são incipientes e a única urbanização restringe-se a uma pequena parte da cidade de Ceará Mirim, correspondente a $0,7 \%$ da bacia. 


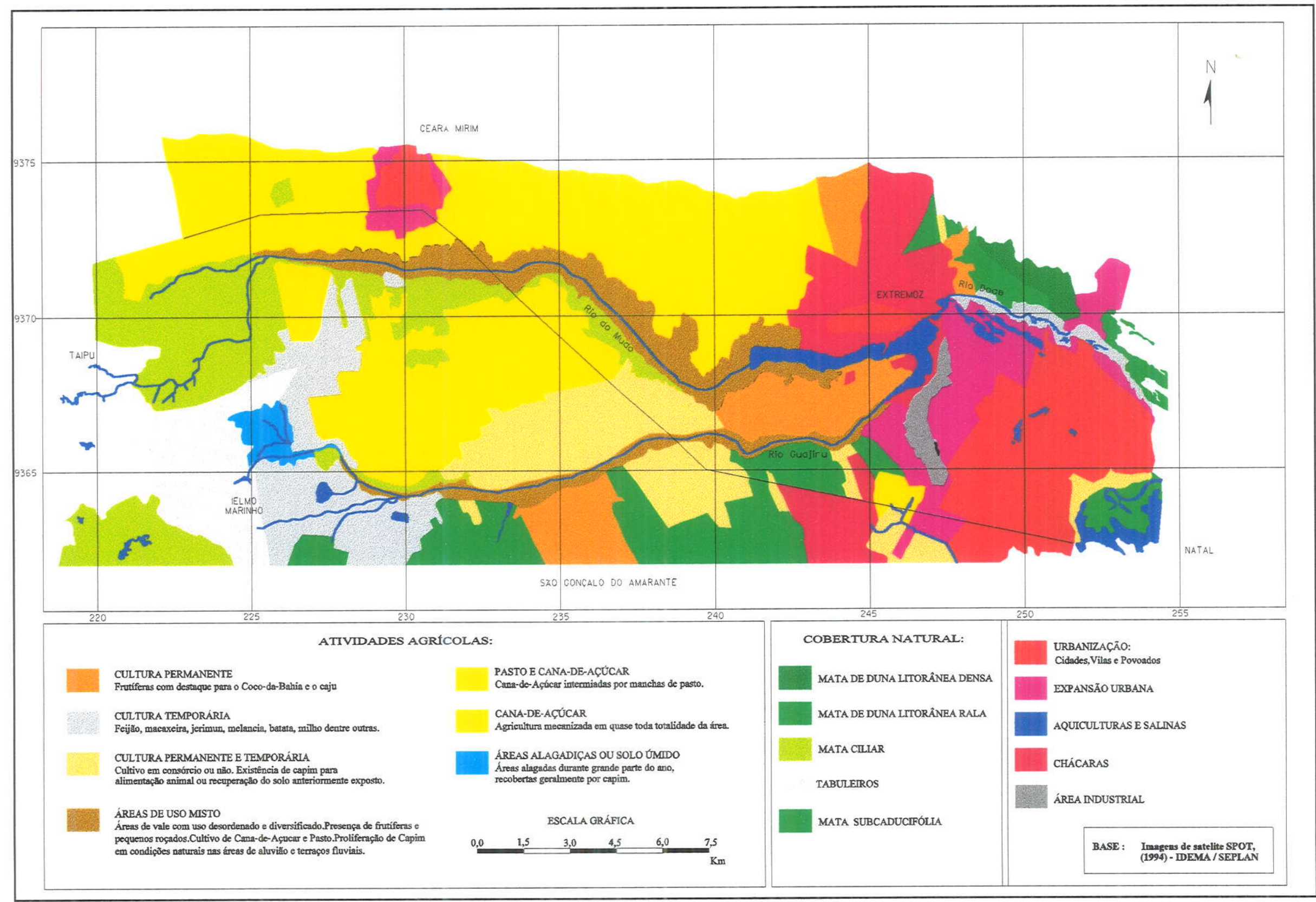

Figura 6.1 - Uso e ocupação do solo

Fonte : (CASTRO, 2000) 


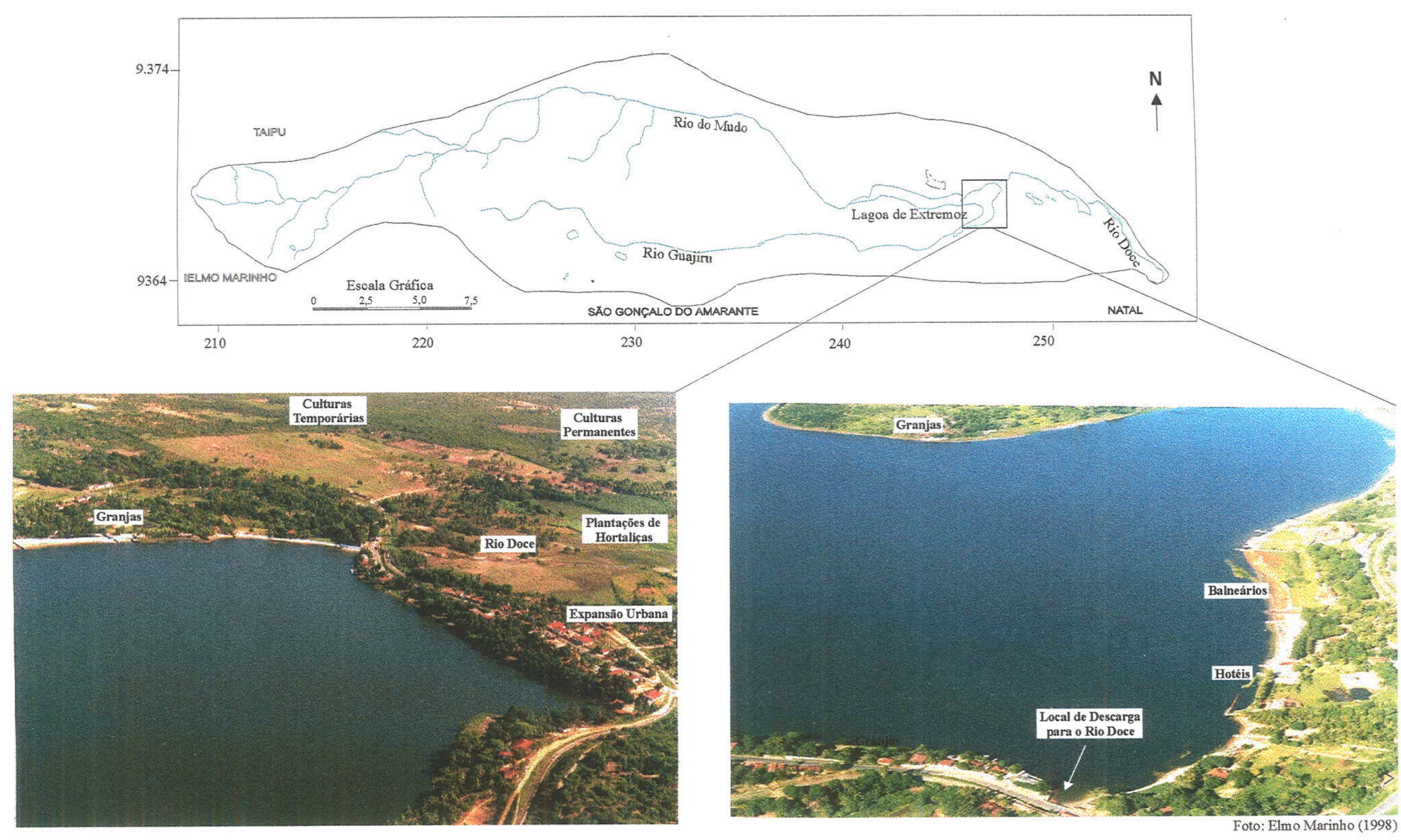

Figura - 6.2 - Vista parcial do uso e ocupação do solo em torno da Lagoa de Extremoz Fonte: (CASTRO, 2000) 


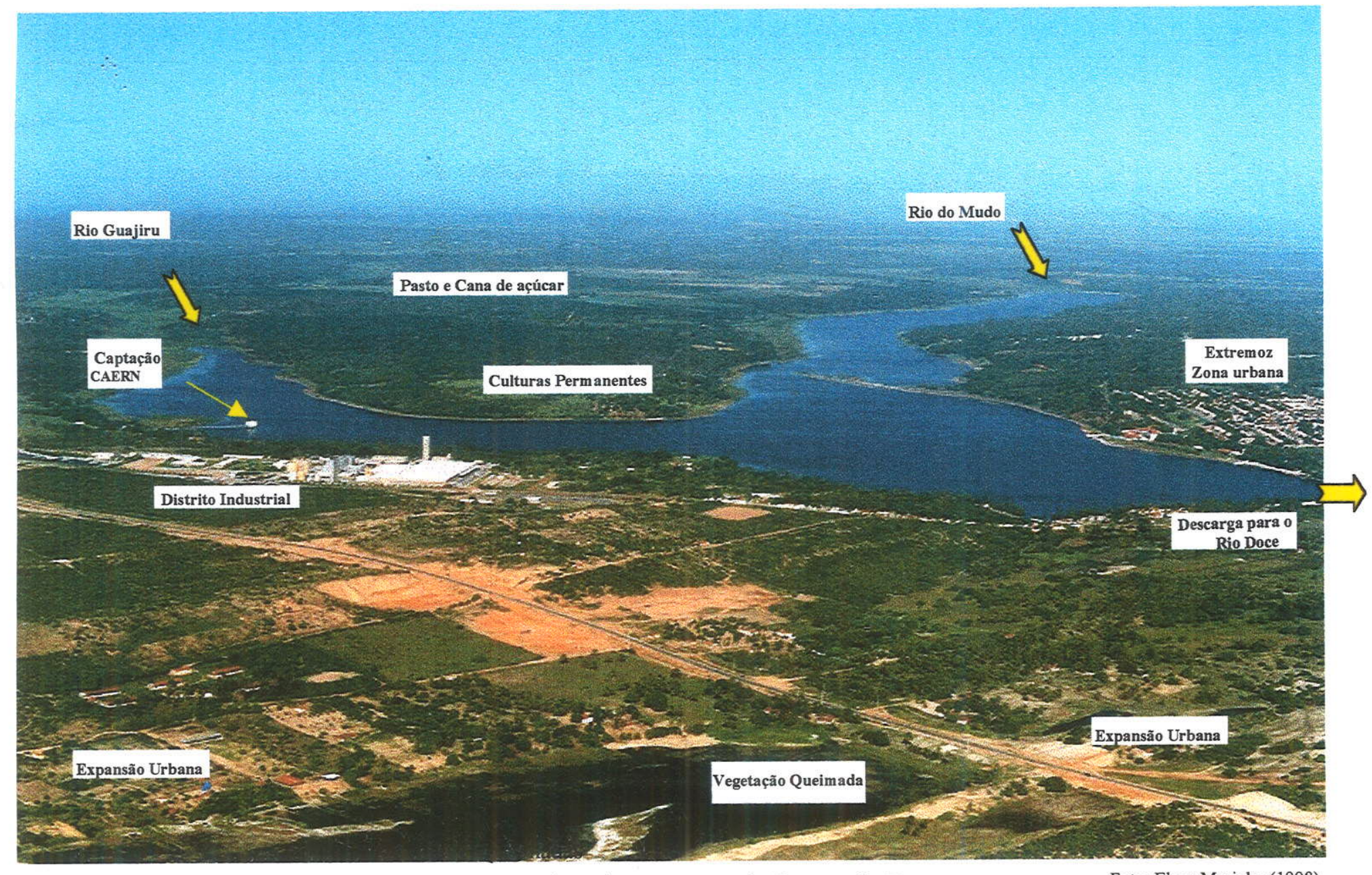

Figura 6.3 - Vista parcial do uso e ocupação do solo em torno da Lagoa de Extremoz Foto: Elmo Marinho (1998) Fonte: (CASTRO, 2000) 
O restante da ocupação se dar com mata ciliar, $(10,4 \%)$, tabuleiros $(2,3 \%)$, e as culturas desenvolvidas que são:

- Temporárias: feijão, mandioca, abóbora, melancia, batata, milho, dentre outras, englobando $5,6 \%$ da área.

- Plantios de Cana de Açúcar intermediadas por Pasto: abrange aproximadamente $16 \%$.

- Áreas de Uso Misto - correspondem a 1,8\% da área da bacia. Referem-se as áreas de vale, com uso desordenado e diversificado. Presença de frutíferas e pequenos roçados. Cultivo de pasto e proliferação de capim em condições naturais nas áreas de aluvião e terraços fluviais.

No segundo trecho, o médio curso da bacia, entre as coordenadas 232,5 e 245,0 (E), onde estão inseridos parte dos municípios de Ceará Mirim, São Gonçalo do Amarante e Extremoz, cerca de $20 \%$ do uso do solo compreende as culturas permanentes, e temporárias, uso misto e plantio de cana de açúcar. A mata subcadiçufólia e tabuleiros correspondem a $14 \%$ da área da bacia, as chácaras compreende aproximadamente $1,5 \%$, a área urbanizada $0,3 \%$ e mata ciliar apenas $0,5 \%$.

O terceiro trecho, o curso inferior da bacia, entre as coordenadas 245 e 255 (E), é onde se concentra a urbanização, abrangendo $10 \%$ da área total da bacia, inchuindo a presença do pólo industrial de Extremoz. A área de expansão urbana é de $20 \mathrm{~km}^{2}$, equivalente a $5 \%$ da área da bacia.

\subsubsection{Legislação sobre o Uso e Ocupação do Solo}

No que concerne a uma legislação específica o Estado do Rio Grande do Norte ainda não dispõe, existindo apenas a legislação ambiental estadual que aborda no uso e ocupação do solo. Dentro deste contexto foi elaborado um resumo das principais leis e decretos existentes.

O Instituto de Desenvolvimento Econômico e Meio Ambiente do Rio Grande do Norte, (IDEC 1998), colocou à disposição dos usuários dos seus serviços o conjunto de normas que disciplinam a atividade ambiental no Estado. Sob o título Legislação Ambiental do RN, esta publicação reúne, em sua $1^{a}$ edição, Leis, Decretos e as Resoluções mais importantes do Conselho Estadual de Meio Ambiente.

LEI $N^{\prime \prime} 5.147$, de 30 de setembro de 1982 - Dispõe sobre a política e o Sistema Estaduais de Controle e Preservação do Meio Ambiente e ressalta: 
- racionalização do uso do solo, do subsolo, da água e do ar;

- controle e zoneamento das atividades potencial ou efetivamente poluidoras;

Art. $5^{\circ}$ - Constituem instrumentos da política estadual de controle e preservação do meio ambiente:

I - zoneamento ambiental;

II - avaliação dos impactos ambientais;

III - o licenciamento e a revisão de atividades efetivas ou potencialmente poluidoras.

Art. $6^{\circ}$ - A construção, a instalação, a ampliação e o funcionamento de estabelecimentos e atividades utilizadoras de recursos ambientais, considerados efetiva ou potencialmente poluidoras, bem como, os capazes, sob qualquer forma, de causar degradação ambiental dependerão de prévio licenciamento pelo conselho estadual de Ciência, Tecnologia e Meio Ambiente, (CECTEMA).

Art. $7^{\circ}$ - Compete ao órgão central do sistema, Secretaria de Planejamento RN, propor ao CECTEMA normas e padrões para a implantação, acompanhamento e fiscalização do licenciamento previsto no artigo anterior.

Art. 11 - A instalação, a construção, ou a ampliação de quaisquer atividades de produção, transformação e comércio que envolvem o aproveitamento e a utilização dos recursos naturais, bem como a edificação ou a reforma de prédios em áreas consideradas de proteção ambiental e a aprovação de loteamentos no estado, ficam sujeitos à prévio registro no órgão central do sistema, que identificará as condições de uso, funcionamento e localização, quanto à possibilidade de vir a causar poluição ambiental e/ ou desequilíbrios ecológicos.

LEI $N^{v} 5.747$, de 30 de dezembro de 1987 - Disciplina proibição de uso de todo território do RN para depósitos de lixo atômico.

LEI $N^{\circ}$ 6.504, de $1^{\circ}$ de dezembro de 1993 - Proíbe a queimada de cana-de-açúcar num raio de 1.000 (mil) metros de distância da periferia das cidades.

LEI $N^{\circ}$ 6.678, de 21 de julho de 1994 - Cria o Fundo Estadual de Preservação do Meio Ambiente (FEPEMA) e dá outras providências.

LEI $N^{\circ}$ 6.769, de 11 de maio de 1995 - Dispõe sobre a política florestal do Estado do RN e dá outras providências. 
Art. $4^{\circ}-$ O poder executivo criará mecanismos de fomentos a:

- complementação à programas de conservação do solo e regeneração ou recomposição de áreas degradadas, incluidas aquelas em processo de desertificação, para incremento do potencial florestal do estado, bem como, a minimização da erosão e o assoreamento de cursos de água, naturais ou artificiais.

Art. 20 - Fica proibida a queimada no preparo do solo objetivando o seu uso alternativo.

LEI $N^{o}$ 6.950, de 20 de agosto de 1996 - Dispõe sobre o plano estadual de gerenciamento costeiro e dá outras providências.

Art. 19 - Parágrafo $1^{\circ}$ Não será permitida a urbanização ou qualquer forma de utilização do solo na zona costeira que impeça ou dificulte o acesso assegurado no "caput" deste artigo.

DECRETO No 7.237, de 22 de novembro de 1977 - Declara de utilidade pública, para fins de desapropriação, bens situados na área das dunas, adjacentes ao oceano atlântico no município de Natal.

DECRETO $N^{0} 8.600$, de 03 de março de 1983 - Aprova o regulamento da política e sistema estaduais de controle e preservação do meio ambiente.

DECRETO $N^{\circ}$ 10.582, de 06 de março de 1990 - Cria o sistema de controle ambiental e sanitário do litoral (SCAL), e dá outras providências.

DECRETO $N^{\circ}$ 12.620, de 17 de maio de 1995 - Cria a Área de Proteção Ambiental (APA) Genipabu, nos municípios de Extremoz e Natal e dá outras providências.

LEI COMPLEMENTAR $N^{\circ}$ 140, de 26 de janeiro de 1996 - Regulamenta os artigos 150 e 154 da constituição estadual e dá outras providências.

DECRETO $N^{\circ} 13.799$, de 17 de fevereiro de 1998 - Aprova o regulamento à lei complementar $\mathrm{N}^{\circ} 140$ de 26 de janeiro de 1996, que dispõe sobre a política e o sistema estadual de controle e preservação do meio ambiente e dá outras providências.

\section{2 - Fontes Potenciais de Contaminação}

Os recursos hidricos da bacia do Rio Doce estão sujeitos à contaminação devido, principalmente, às atividades do desenvolvimento urbano e industrial. Destacam-se como 
principais fontes de contaminação, a disposição local de efluentes domésticos (fossas), lagoas de estabilização e a ocupação do terreno, entre outras como: postos de combustível, cemitérios, poços sem proteção sanitária, cacimbas transformadas em fossa e os lixões. Esta situação gera problemas graves na saúde da população, pois sabe-se que os sistemas de saneamento com disposição local dos efluentes podem contaminar as águas subterrâneas por microorganismos patogenéticos e produtos da bio-degradação dos excrementos humanos. Durante o processo de penetração dos efluentes no solo esses microorganismos são eliminados total ou parcialmente pelos fenômenos de filtração e adsorção. O grau de eficácia desta purificação, dependerá fundamentalmente da vulnerabilidade do meio não saturado com relação a sua litologia e profundidade das águas subterrâneas.

Os microorganismos patogênicos contidos na matéria fecal, são representados por ovos de helmintos, protozoários e por bactérias e vírus. Os helmintos e protozoários são de dimensões relativamente grandes (superiores a 25 micros), sendo facilmente filtrados através do solo e geralmente não oferecem riscos para as águas subterrâneas. As bactérias e vírus por serem muito pequenos podem ser transportados, através da percolação dos efluentes, desde os sistemas sanitários locais até às águas subterrâneas, contaminando-as e colocando em risco a saúde da população que as consome. No entanto, isto só ocorre em função das características do meio não saturado e do sistema aqǘfero, onde predominem sedimentos arenosos e nível de água raso. Quando se trata de terrenos argilosos e nível de água profundo o tempo de permanência dos efluentes na zona não saturada é muito maior, propiciando ações efetivas de eliminação dos contaminantes.

Através de estudos realizados por LEWIS et al. (1988) foi verificado que normalmente o risco de contaminação de origem fecal da água subterrânea é mínimo quando a espessura dos substratos não saturados abaixo da base das fossas é superior a $2 \mathrm{~m}$ ou quando as cargas hidráulicas que provém destes sistemas de deposição local de efluentes não excedem $30 \mathrm{~mm} /$ dia e as partículas do solo são inferiores a $1 \mathrm{~mm}$.

\subsection{1 - Atividades Industriais}

Foram cadastradas indústrias, de pequeno porte (30 funcionários), e indústrias de porte elevado (com 624 funcionários), cuja disposição espacial está representada na figura 6.4 . 


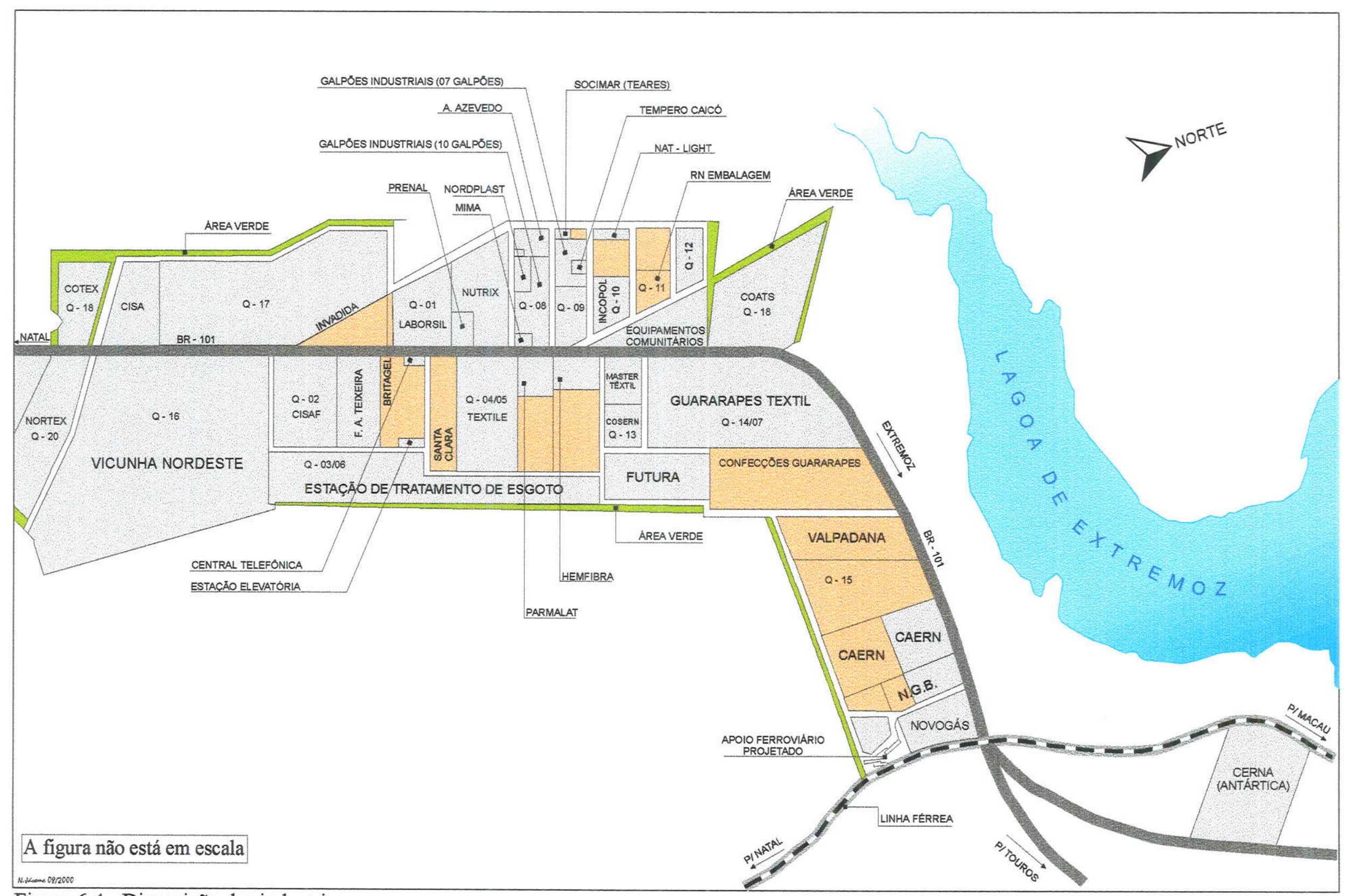

Figura 6.4 - Disposição das industrias

Fonte (Secretaria da Indústria e do Comércio/RN, 1999) 
A tabelas 6.1 indica o consumo de água nas indústrias, a tabela 6.2 e figuras 6.5 e 6.6 compreendem os volumes dos efluentes industriais. Em função do tipo de indústria foi definido o indice de contaminação potencial e considerando o volume de água utilizado foi caracterizada a categoria de perigo potencial de contaminação para as águas subterrâneas, seguindo a metodologia estabelecida por FOSTER \& HIRATA (1991).

Entre as indústrias cadastradas, três foram consideradas de alto perigo potencial de contaminação para as águas subterrâneas, (tabela 6.3): LABORSI, cujo principal tipo de contaminante envolvido é a matéria orgânica e orgânicos sintéticos (produtos farmacêuticos); NOVOGÁS, com perigo potencial de contaminação por matéria orgânica, hidrocarbonetos e orgânicos sintéticos (petróleo/gás); HENFIBRA, contaminação por orgânicos sintéticos (plástico/fibra de vidro). Os efluentes industriais são conduzidos para uma lagoa de estabilização situada nas imediações da CISAF E VICUNHA.

Tabela 6.1 - Consumo de água nas Unidades Industriais

\begin{tabular}{|l|r|r|r|l|}
\hline $\begin{array}{c}\text { Unidade } \\
\text { Industrial }\end{array}$ & $\begin{array}{c}\text { Manancial de } \\
\text { Captação }\end{array}$ & $\begin{array}{r}\text { Consumo de } \\
\text { Água }\left(\mathrm{m}^{3} / \mathrm{ano}\right)\end{array}$ & $\begin{array}{c}\text { Drenagem de Efluentes } \\
\text { Liquidos }\end{array}$ & $\begin{array}{c}\text { Conteúdo dos Efluentes } \\
\text { Liquidos }\end{array}$ \\
\hline Vicunha & Poço Tubular & $402.0844,00$ & Lagoa de Estabilização (CAERN) & Resíduo Orgânico \\
\hline Henfibra & Poço Tubular & $1.800,00$ & Fossa com Sumidouro & Resíduo Orgânico \\
\hline Mastex & Poço Tubular & $302.400,00$ & Lagoa de Estabilização (CAERN) & Resíduo Orgânico \\
\hline Parmalat & Poço Tubular & $268.800,00$ & Lagoa de Estabilização (CAERN) & Resíduo Orgânico \\
\hline Guarap.Textil & Poço Tubular & $364.792,78$ & Lagoa de Estabilização (CAERN) & Resíduo Orgânico \\
\hline Antártica & Poço Tubular & $4 \times 10^{6}$ & Lagoa de Estabilização (CAERN) & Não contém resíduos \\
\hline Laborsil & Poço Tubular & $8.448,00$ & Lagoa de Estabilização (CAERN) & Não contém resíduos \\
\hline Coats & Poço Tubular & $350.400,00$ & Lagoa de Estabilização (CAERN) & Residuo Orgânico \\
\hline
\end{tabular}

Fonte: (CASTRO, 2000)

Tabela 6.2 - Volumes dos efluentes industriais registrados pela CAERN em 1996

\begin{tabular}{|l|r|r|r|r|r|r|r|r|r|r|}
\hline & Janeiro & Fevereiro & Março & Abril & Maio & Junho & Julho & Agosto & $\mathrm{m}^{3} / \mathrm{dia}$ & $\mathrm{m}^{3} / \mathrm{mês}$ \\
\hline VICUNHA & & & & - & 49.421 & 59.306 & 56.330 & 39.411 & 1.977 & 51.117 \\
\hline PARMALAT & 7.446 & 7.268 & 7.703 & 7.013 & 8.895 & 9.895 & 11.105 & 10.874 & 370 & 8.775 \\
\hline MASTEX & 1.645 & 4.491 & 2.594 & 2.594 & 1.762 & 5.094 & 8.188 & 4.837 & 273 & 3.900 \\
\hline GUARARAPES & 16.519 & 4.026 & 16.059 & 16.059 & 9.720 & 12.073 & 17.255 & 14.308 & 575 & 12.779 \\
\hline ANTARTICA & 34.435 & 50.457 & 51.460 & 51.460 & 42.218 & 53.503 & 43.200 & 47.210 & 1.783 & 46.056 \\
\hline
\end{tabular}

Fonte: (CAERN, 1996) 


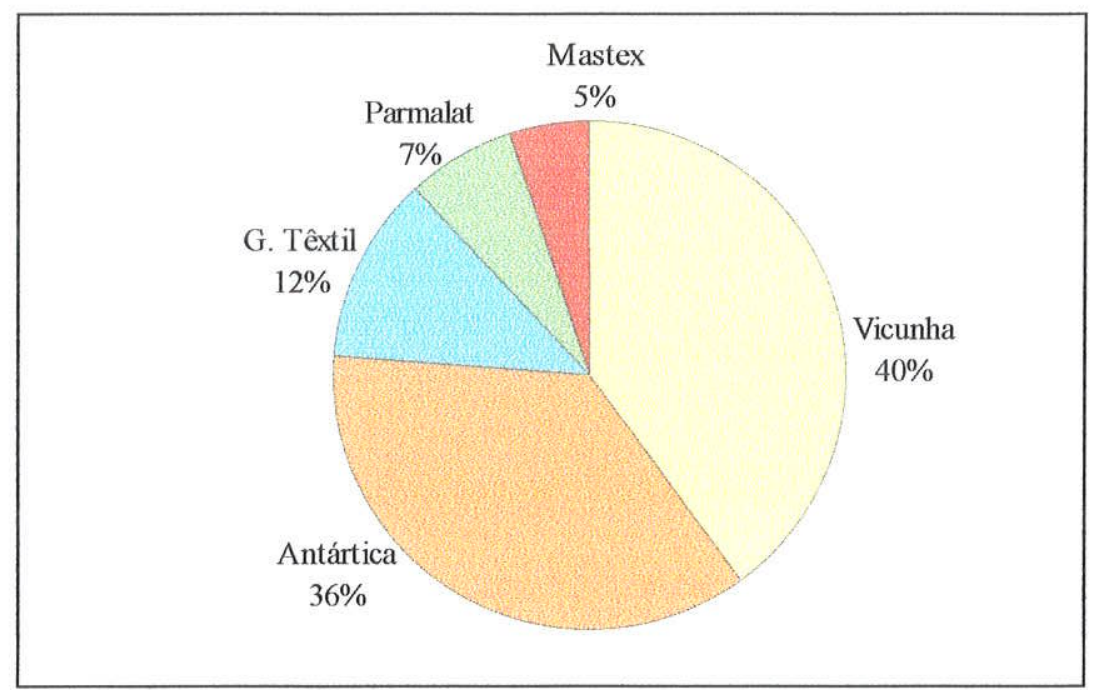

Figura 6.5 - Produção média diária de efluentes industriais Fonte: (CAERN, 1996)

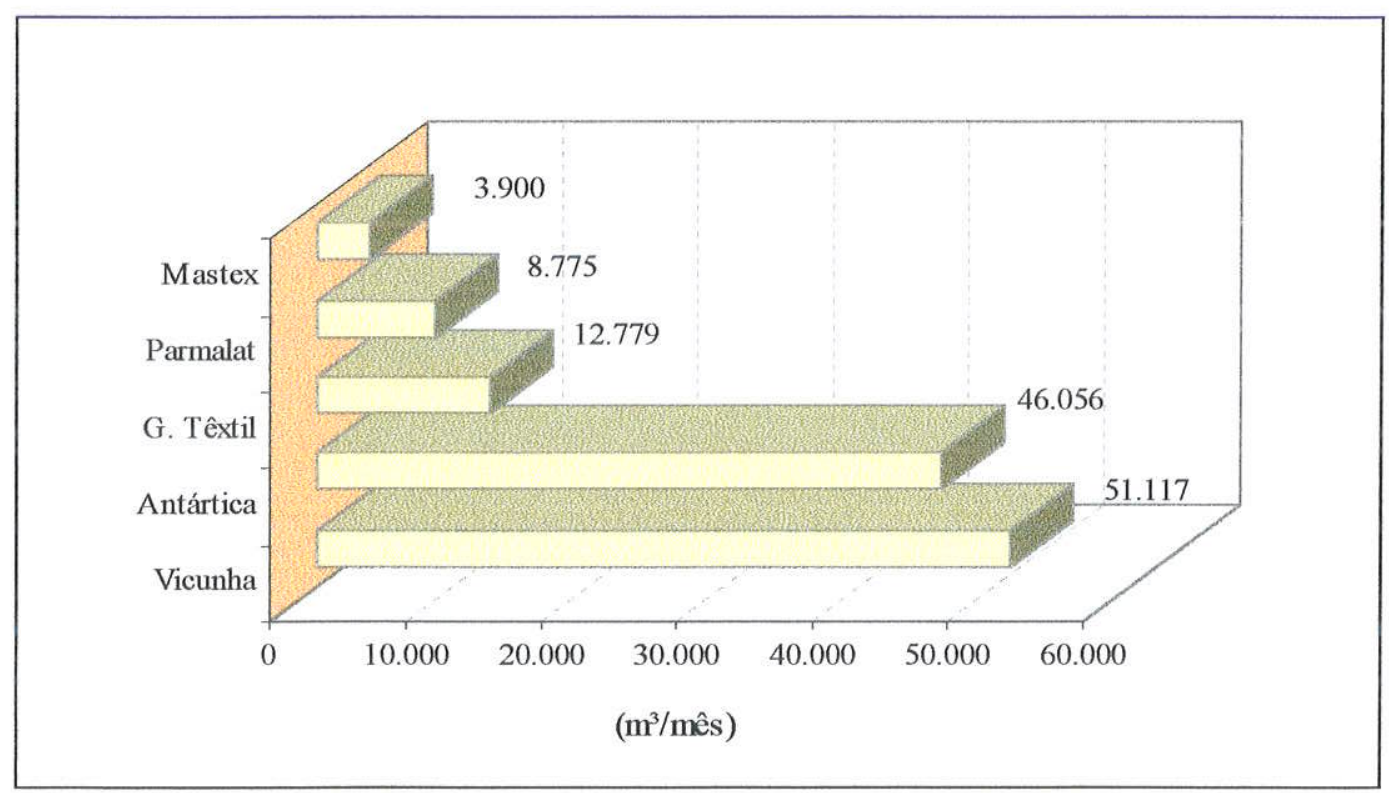

Figura 6.6 - Produção média mensal de efluentes industriais Fonte: (CAERN, 1996)

\subsection{2 - Lagoa de Estabilização}

Entre os processos de tratamento mais utilizados pela engenharia sanitária e ambiental em todo o mundo, pela sua eficiência e economia, têm-se destacado os sistemas de lagoas de estabilização. 
Tabela 6.3 - Categoria de perigo potencial para as águas subterrâneas devido as atividades industriais

\begin{tabular}{|c|c|c|c|c|c|c|}
\hline ID & Indústria & $\begin{array}{l}\text { Atividade } \\
\text { Industrial }\end{array}$ & Principal Contaminante & $\begin{array}{c}\text { Indice de } \\
\text { Contaminaçăo } \\
\text { Potencial }\end{array}$ & $\begin{array}{c}\text { Uso da } \\
\text { Agua }\left(\mathrm{m}^{\mathbf{3}} / \mathrm{dia}\right)\end{array}$ & Perigo Potencial \\
\hline 1 & Henfibra & $\begin{array}{l}\text { Fibra de vidro } \\
\text { Plástico }\end{array}$ & Orgânico Sintético & 3 & $<100$ & Alta \\
\hline 2 & Laborsil & Farmacêuticos & $\begin{array}{l}\text { Material Orgânico e } \\
\text { Orgânicos Sintéticos }\end{array}$ & 3 & $<100$ & Alta \\
\hline 3 & Novogás & Petróleo/gás & $\begin{array}{l}\text { Material Orgânico, } \\
\text { Hidrocarboneto, Orgânico } \\
\text { Sintético }\end{array}$ & 3 & $<100$ & Alta \\
\hline 4 & Vicunha & Têxtil & $\begin{array}{l}\text { Material Orgânico e } \\
\text { Orgânico Sintético }\end{array}$ & 2 & $100-1000$ & Moderado \\
\hline 5 & Mastex & Têxtil & $\begin{array}{l}\text { Material Orgânico e } \\
\text { Orgânico Sintético }\end{array}$ & 2 & $100-1000$ & Moderado \\
\hline 6 & $\begin{array}{l}\text { Guararapes } \\
\text { Têxtil }\end{array}$ & Têxtil & $\begin{array}{l}\text { Material Orgânico e } \\
\text { Orgânico Sintético }\end{array}$ & 2 & $100-1000$ & Moderado \\
\hline 7 & Coats & Têxtil & $\begin{array}{l}\text { Material Orgânico e } \\
\text { Orgânico Sintético }\end{array}$ & 2 & $100-1000$ & Moderado \\
\hline 8 & Parmalat & Alimento & $\begin{array}{l}\text { Nutriente, Matéria } \\
\text { Orgânica e Patógenos }\end{array}$ & 1 & $100-1000$ & Moderado \\
\hline 9 & Antártica & Bebida & Matéria Orgânica & 1 & $>1000$ & Moderado \\
\hline
\end{tabular}

Fonte: (CASTRO, 2000)

Normalmente essas lagoas tem um fundo impermeabilizado à um nível diferenciado, resultado da compactação do solo e da sedimentação, tais condições geralmente permitem infiltração equivalente a $10-20 \mathrm{~mm} /$ dia e, portanto, essas lagoas são uma causa freqüente de contaminação das águas subterrâneas.

De acordo com FOSTER \& HIRATA (1991), nenhum material de custo razoável, disponivel na atualidade, permanece impermeável por longos periodos, especialmente se as lagoas contém químicos corrosivos ou são submetidos a limpezas periódicas. Dessa forma espera-se que ocorra alguma fuga em lagoas revestidas, ainda que à taxas mais baixas que àquelas referidas anteriormente.

No curso inferior da bacia estudada existe um sistema de lagoas de estabilização nas imediações do Polo Industrial, que recebe efluentes das indústrias e nas suas proximidades foi construído um poço de monitoramento (figura 6.7), pela CAERN, para verificação e acompanhamento da qualidade das águas subterrâneas.

O perfil litológico da sondagem até o nivel da água (14,13 metros) apresenta uma seqüencia de arenitos argilosos, o que permitiu caracterizar o local como sendo de vulnerabilidade moderada. 


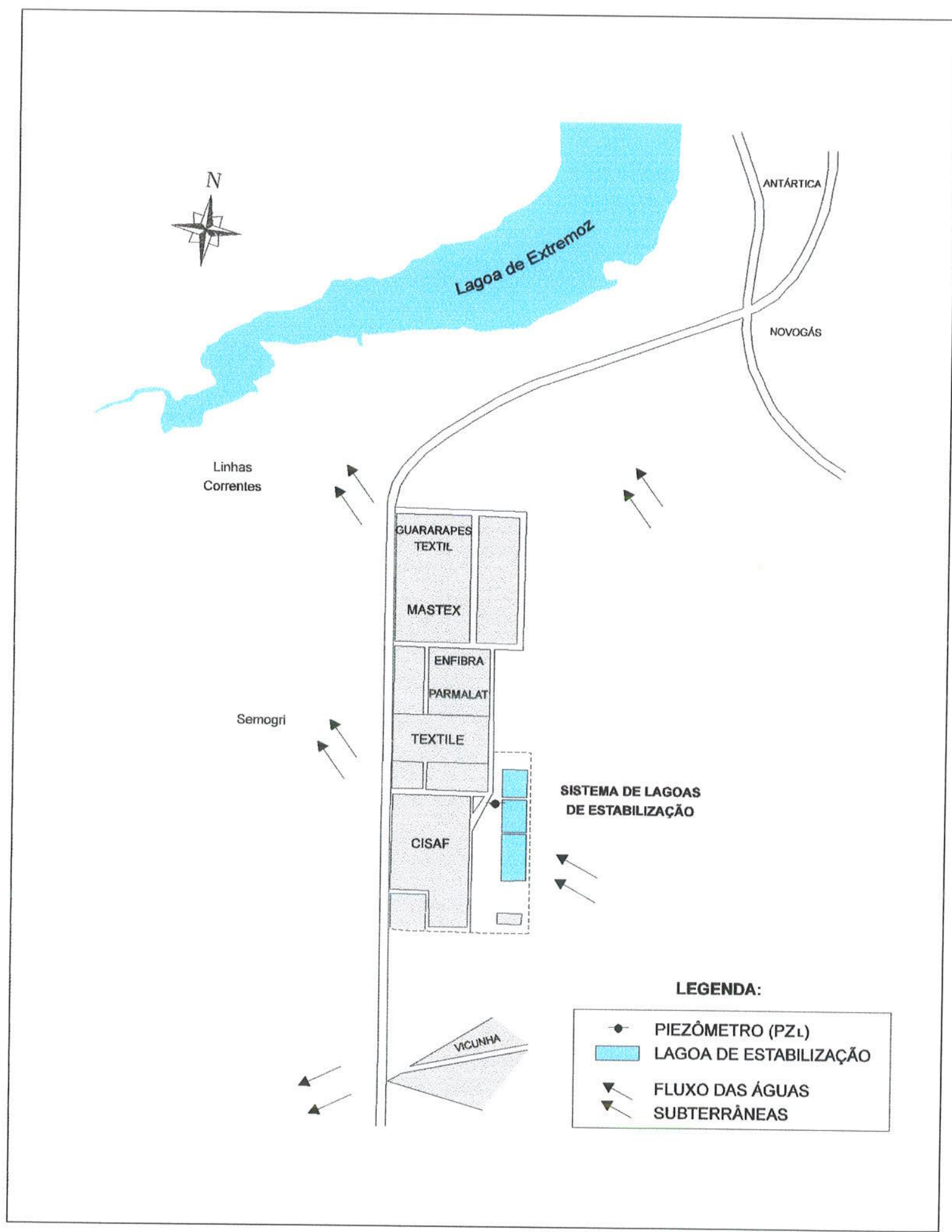

Figura 6.7 - Sistema de lagoas de estabilização do distrito industrial Fonte: (MELO, 1998) 
Este poço de monitoramento foi submetido a bombeamento para a verificação da qualidade das águas e possiveis modificações hidroquímicas. Após 1 hora de bombeamento a condutividade elétrica foi de $325 \mu \mathrm{S} / \mathrm{cm}$ e após 4 horas de bombeamento a condutividade foi de $305 \mu \mathrm{S} / \mathrm{cm}$. O cloreto variou de 81 a $85 \mathrm{mg} / \mathrm{L}$ respectivamente. Estes valores quando comparados aos valores representativos da área $100 \mu \mathrm{S} / \mathrm{cm}$ para a condutividade e $10 \mathrm{mg} / \mathrm{L}$ para o cloreto, são considerados elevados. Os teores de nitrato obtidos foram baixos com valores de 2,1 $\mathrm{mg} / \mathrm{L}$ com 1 hora de bombeamento e $1,8 \mathrm{mg} / \mathrm{L}$ com 4 horas de bombeamento.

\subsection{3 - Expansão Urbana}

Os efeitos impactantes do processo de urbanização manifestam-se muito lentamente e, assim sendo, com efeitos cumulativos, não observáveis diretamente e de dificil restauração.

$\mathrm{Na}$ bacia hidrográfica estudada existem atualmente três núcleos urbanos, referem-se a uma parte da cidade de Ceará Mirim, outra da cidade de Extremoz e alguns conjuntos habitacionais da Zona Norte de Natal, no setor leste da área em estudo.

MELO (1998) identificou o setor leste da área de estudo, à margem direita do rio Doce, como uma região de maior potencial hidrogeológico no âmbito da zona norte de Natal. Esta área, entretanto, muito embora possua algums espaços pouco habitados, já encontra-se intensamente loteado para futuras ocupações, com riscos de degradação das águas subterrâneas.

\subsection{4 - Outras fontes ou atividades potencialmente contaminantes}

No domínio da bacia hidrográfica, principalmente nas proximidades das cidades de Ceará Mirim, Extremoz e Zona Norte de Natal, ocorrem outras fontes ou atividades potencialmente contaminantes das águas subterrâneas, destacando-se:

- Resíduos Sólidos

- Cemitérios

- Atividades agrícolas

- Postos de gasolina

- Poços sem proteção sanitária

- Cacimbas transformadas em fossas negras 


\subsubsection{1 - Resíduos Sólidos}

Os resíduos sólidos de origem doméstica depositados na superficie do solo ou dispostos nos aterros sanitários tem sido causadores de contaminações das águas subterrâneas. Neste processo, que envolve a decomposição biológica dos resíduos, é produzido um liquido de coloração escura conhecido como chorume, o qual pode se infiltrar no terreno e atingir as águas subterrâneas, contaminando-as. O chorume contém, geralmente, um grande número de contaminantes orgânicos e inorgânicos que inclui compostos de nitrogênio e metais pesados.

Os riscos aumentam quando a deposição de resíduos sólidos é realizada em locais sob condições hidrogeológicas vulneráveis. Estes riscos tornam-se mais potencializados quando falta o controle e o gerenciamento dos depósitos. Acontece que em muitos casos, os resíduos industriais e hospitalares são colocados em áreas destinadas aos resíduos domésticos e na maioria dos casos isso ocorre clandestinamente dificultando uma avaliação precisa dos perigos de contaminação para as águas subterrâneas.

De acordo com os dados divulgados no Plano Estadual de Recursos Hídricos, (SERHID, 1998b) o destino dos resíduos sólidos domésticos do município de Extremoz compreende $19,8 \%$ de domicílios servidos pela coleta de lixo de $19,8 \%$, os domicílios que tem o lixo queimado ou enterrado correspondem a $53,7 \%$ e aqueles cujo lixo é jogado representa $26,1 \%$, e outras formas 0,4\%. Na cidade de Ceará Mirim dos 10.126 domicílios, $46,6 \%$ tem o lixo coletado, $31,6 \%$ queimado ou enterrado, 6,0\% jogado fora e $15,8 \%$ usam outros meios. Alerta-se para o fato de que atualmente o lixo considerado como "coletado", nos municípios citados, é depositado sobre a superficie do solo a céu aberto. No que diz respeito aos municípios de São Gonçalo do Amarante, Taipu e Ielmo Marinho, o lixo é depositado fora da área de domínio da bacia do Rio Doce.

Parte da zona Norte de Natal, que está inserida na bacia estudada tem o lixo coletado

e destinado ao parque de reciclagem e compostagem situado no bairro de Cidade Nova em Natal, bacia hidrográfica do Potengi.

\subsubsection{2-Cemitérios}

Alguns trabalhos sobre os impactos ambientais de cemitérios em meios urbanos foram desenvolvidos no Estado de São Paulo, destacando-se: PACHECO (1986); PACHECO et 
al. (1988); PACHECO \& MENDES (1990); PACHECO et al. (1990); MARTINS et al. (1991) e PACHECO et al. (1992). De acordo com os respectivos estudos, a presença de cemitérios em meios urbanos podem provocar impactos físicos ao meio ambiente, entre estes o mais importante está no risco de contaminação das águas subterrâneas por bactérias e por nitrato. A contaminação ocorre mediante a proliferação de microorganismos durante o processo de decomposição dos corpos. No domínio da bacia hidrográfica existem sete cemitérios, e em apenas um todos os cadáveres são dispostos em gavetas de concreto, os outros, 10 a $30 \%$ dos caixões são enterrados na areia.

\subsubsection{3 - Atividade Agrícola}

A caracterização dos impactos causados pela atividade agrícola nas águas subterrâneas ainda é uma das mais dificeis de ser avaliada. Até a década de 60, os agrotóxicos eram tidos como causadores de baixo impacto nos aqüúferos. Com a atuação das instituições de controle ambiental em países europeus e norte americanos, iniciaram-se as campanhas de monitoramento das águas subterrâneas e foi constatado a contaminação dos aqüíferos, com maior freqüência, pela atividade agrícola.

Segundo HIRATA (1994), o uso de fertilizantes inorgânicos está se expandindo de forma bastante rápida nos países periféricos, no intuíto de aumentar a produtividade agrícola. Assim, os solos, anteriormente pobres em nutrientes, passaram a conter excesso intermitente de sais, de compostos nitrogenados e de outros produtos que, mobilizados pelo excesso de água infiltrada, podem chegar a contaminar os aqüiferos.

A caracterização do comportamento dos pesticidas deve considerar: umidade, temperatura, $\mathrm{pH}$, matéria orgânica e argila do solo, em interação com os efeitos climáticos. Estes parâmetros têm influência direta na adsorção, volatização e na fotodegradação, e de forma indireta nos processos de degradação microbiológicos, (HIRATA op.cit).

COHEN et al. (1984) destaca as seguintes características, para os pesticidas potencialmente contaminantes:

- $\quad$ solubilidade maior que 30ppm;

- $\mathrm{Kd}$ (coeficiente de partição) menor que 5;

- degradação na zona de raiz maior que 2 a 3 semanas; meia vida hidrolítica menor que 6 meses. 
No domínio da área estudada, atualmente merecem destaque os plantios de cana de açúcar, compreendendo aproximadamente $20 \%$ do total da área da bacia, distribuídos no seu superior e médio curso; os projetos de irrigação de fruticulturas localizados entre os Rios do Mudo e Guajiru e as plantações hortigranjeiras desenvolvidas ao longo do rio Doce. Na tabela 6.4 estão resumidas as características dos principais fertilizantes agrícolas.

Tabela 6.4 - Resumo das características dos principais fertilizantes agrícolas

\begin{tabular}{|c|c|c|c|c|c|c|c|}
\hline \multirow[t]{2}{*}{ Tipo } & \multirow[b]{2}{*}{ Adsorção no Solo } & \multicolumn{4}{|c|}{ Mobilidade no Solo Transformą̧äo } & \multicolumn{2}{|c|}{$\begin{array}{c}\text { Possiveis } \\
\text { Contaminantes }\end{array}$} \\
\hline & & Cátions & Anions & Quim. & Biol. & Cátion & Ánions \\
\hline $\begin{array}{l}\text { De Nitrogênio } \\
\text { Nitrato de Cálcio } \\
\text { Salitre de Amônio } \\
\text { Salitre de Sódio } \\
\text { Salitre de Potássio } \\
\text { Salitre de Amônio e Cal } \\
\text { Sulfato de Amônio } \\
\text { Amoníaco Líquido } \\
\text { Águá amoniacal } \\
\text { Uréia } \\
\text { Cianamida Cálcica Uréia } 50 \text { amoniaco } 50\end{array}$ & $\begin{array}{l}\text { baixo, s/e Ca } \\
\text { parcial s/e } \mathrm{NH}^{4} \\
\text { baixa s/e Na } \\
\text { baixa s/e K } \\
\text { aumento } \mathrm{NH}^{4} \\
\text { parcial s/e } \mathrm{NH}^{4} \\
\text { alta } \mathrm{NH}^{4} \\
\text { parcial } \mathrm{NH}^{4} \\
\text { parcial } \mathrm{NH}^{4} \\
\text { parcial } \mathrm{NH}^{4}\end{array}$ & $\begin{array}{l}\text { baixa } \\
\text { baixa } \\
\text { baixa } \\
\text { baixa } \\
\text { baixa } \\
\text { baixa } \\
\text { baixa } \\
\text { baixa } \\
\text { baixa } \\
\text { baixa }\end{array}$ & $\begin{array}{l}\text { alta } \\
\text { alta } \\
\text { alta } \\
\text { alta } \\
\text { alta } \\
\text { média } \\
\text { alta } \\
\text { alta } \\
\text { aita } \\
\text { aita }\end{array}$ & $\begin{array}{l}\text { * } \\
\text { * } \\
\text { * }\end{array}$ & $\begin{array}{l}\text { * } \\
* \\
\text { * } \\
\text { * } \\
\text { * } \\
\text { * } \\
\text { * }\end{array}$ & $\begin{array}{l}\mathrm{NH}^{4} \\
\mathrm{NH}^{4} \\
\mathrm{NH}^{4} \\
\mathrm{NH}^{4} \\
\mathrm{NH}^{4} \\
\mathrm{NH}^{4} \\
\mathrm{NH}^{4} \\
\mathrm{NH}^{4} \\
\mathrm{NH}^{4} \\
\mathrm{NH}^{4} \\
\mathrm{NH}^{4}\end{array}$ & $\begin{array}{l}\mathrm{NO}^{3} ; \mathrm{NO}^{4} \\
\mathrm{NO}^{3} ; \mathrm{NO}^{4} \\
\mathrm{NO}^{3} ; \mathrm{NO}^{4} \\
\mathrm{NO}^{3} ; \mathrm{NO}^{4} \\
\mathrm{NO}^{3} ; \mathrm{NO}^{4} \\
\mathrm{NO}^{3} ; \mathrm{NO}^{4} \\
\mathrm{NO}^{3} ; \mathrm{NO}^{4} \\
\mathrm{NO}^{3} ; \mathrm{NO}^{4} \\
\mathrm{NO}^{3} ; \mathrm{NO}^{4} \\
\mathrm{NO}^{3} ; \mathrm{NO}^{4} \\
\mathrm{NO}^{3} ; \mathrm{NO}^{4}\end{array}$ \\
\hline $\begin{array}{l}\text { De Fósforo } \\
\text { Surfosfato } \\
\text { Surfosfato Granulado } \\
\text { Tri-Superfosfato } \\
\text { Fosfato Pulverizado } \\
\text { Pó de Thonas } \\
\text { Superfosfato simples + Fosfato Cru } \\
\text { De Potássio } \\
\text { Cloreto de Potássio } \\
\text { Cloreto de Potássio } \\
\text { Sulfato de magnésio } \\
\text { Kainit } \\
\text { Sulfato de Potássio } \\
\text { NPK combinado }\end{array}$ & $\begin{array}{l}\text { muito alta } \\
\text { muito alta } \\
\text { muito alta } \\
\text { muito alta } \\
\text { muito alta } \\
\text { muito alta }\end{array}$ & $\begin{array}{l}\text { Extema e } \\
\text { baixa } \\
\text { Extrema } \\
\text { e baixa } \\
\text { Extrema } \\
\text { e baixa } \\
\text { Extrema } \\
\text { e baixa } \\
\text { Extrema } \\
\text { e baixa } \\
\text { Extrema } \\
\text { e baixa } \\
\text { baixa } \\
\text { baixa } \\
\text { baixa } \\
\text { baixa } \\
\text { baixa }\end{array}$ & $\begin{array}{l}\text { alta } \\
\text { baixa } \\
\text { alta } \\
\text { média } \\
\text { alta }\end{array}$ & $*$ & * & $\left\{\begin{array}{l}\mathrm{k} \\
\mathrm{K} \\
\mathrm{K}\end{array}\right.$ & $\begin{array}{l}\mathrm{HPO}^{4} \\
\mathrm{HPO}^{4} \\
\mathrm{HPO}^{4} \\
\mathrm{HPO}^{4} \\
\mathrm{HPO}^{4} \\
\mathrm{HPO}^{4}\end{array}$ \\
\hline
\end{tabular}

Fonte: (VRBA \& ROMIJN, 1986) 


\subsubsection{4 - Postos de Gasolina}

A gasolina comporta-se como um contaminante complexo em subsuperficie, tendo em vista que todos os componentes físico-químicos, como densidade, viscosidade e composição química, tem relevância no processo de contaminação. A descontaminação natural da área atingida, por degradação biológica do contaminante, pode levar anos e a remediação requer uma caracterização detalhada e criteriosa do problema.

Estudos mostram que os tanques de armazenamento subterrâneo, construídos em chapa de aço, corroem e vazam num periodo médio de 20 anos a partir de sua instalação. OLIVEIRA et al. (1990) em estudos realizados no Estado de São Paulo, ressaltam os efeitos impactantes atribuídos a esses reservatórios e verificaram vários casos de poços contaminados por hidrocarbonetos devido a vazamentos nos tanques de combustível em consequêencia da ação corrosiva sobre estes depósitos.

$\mathrm{Na}$ área estudada existem hoje cerca de 10 postos de combustível, distribuídos principalmente no curso inferior da bacia hidrográfica, onde há maior tráfego de automóveis com destino às praias. A quantidade destas unidades de abastecimento, atualmente não é considerada um problema, mas existe um agravante, no que se refere ao tipo geológico dos locais onde estão instalados os postos de gasolina, pois o meio insaturado em determinados locais é constituído por areias das dunas, apresentando-se com elevadas taxas de infiltração, da ordem de $43 \%$.

\subsubsection{5 - Poços sem Proteção Sanitária e Cacimbas Transformadas em Fossas Negras}

MELO (1998) faz referências a alguns poços do Sistema Público de Abastecimento de Água, na Zona Norte de Natal, que não apresentam proteção sanitária e em outros casos esta proteção é inadequada, o que pode facilitar a penetração de águas contaminadas no interior dos poços, através dos seus pré filtros. É o que ocorre no poço Pt-12 da Captação Pajuçara/Gramoré (CAERN), e alguns poços antigos da Fundação Nacional de Saúde (FNS), como por exemplo o caso do poço Pt-03, localizado no Conjunto Habitacional da Marinha na cidade de Extremoz. Também existem referências de casos de poços tipo cacimbão construidos inicialmente para captação de água e que hoje são utilizados como depósitos de efluentes domésticos, constituindo as "fossas negras" e gerando riscos de contaminação para as águas subterrâneas. 


\section{0 - SAÚDE PÚBL.ICA}

Historicamente os aglomerados urbanos desenvolvem-se nas proximidades de rios, lagos e outros mananciais e, naturalmente a necessidade de saneamento se torna necessária em todas as relações do homem com o ambiente. Estas relações contemplam um único objetivo que é o de promover a saúde e conforto dos indivíduos, através das estruturas de controle de doenças e garantia da qualidade ambiental.

A falta de valorização das linhas de ações na área de saneamento tem gerado graves problemas na saúde do planeta. No mundo cerca de 500 milhões de pessoas sofrem de afecção transmitida pela água, 25 por cento dos leitos hospitalares de todo o mundo são ocupados por pacientes que sofrem de algum mal de veiculação hídrica.

Segundo dados da Organização Mundial de Saúde (1996), (apud Secretaria de Saúde Pública do Estado do Rio Grande do Norte 1997), 80\% das doenças que ocorrem nos países em desenvolvimento são ocasionadas pela contaminação da água e que, a cada ano, 15 milhões de crianças de 0 a 5 anos morrem direta ou indiretamente pela falta ou deficiência dos sistemas de abastecimento de águas e esgotos.

O Brasil apresenta atualmente uma situação crítica na área de saúde pública, segundo dados levantados por GARCIAS \& NUCCI (1993). O país, ocupa o $70^{\circ}$ lugar em esgotamento sanitário e segundo a Unicef, o $4^{\circ}$ lugar em mortalidade infantil na América Latina, cujo coeficiente é de 64 óbitos por mil nascimentos. A Organização Mundial de Saúde (1996) (apud Secretaria de Saúde Pública do Estado do Rio Grande do Norte 1997), sugere uma taxa máxima de mortalidade infantil de 50 por mil nascidos vivos.

Enfim, a alta taxa de urbanização com o declinio nos investimentos no setor de saneamento conduz ao caos urbano, gerando para uma grande parte da população, condições subumanas de vida.

A origem da maior parte das doenças está na dependência quase exclusiva da poluição das águas. A incidência de doenças como verminoses, parasitoses, infecções intestinais repetidas, micoses, tifo e cólera está diretamente ligada à poluição e/ou contaminação hídrica. O mais agravante é o fato de que o preço a pagar pela ingestão de águas poluídas microbiologicamente é dificil de ser computado. O quadro 7.1 apresenta o resumo das doenças de veiculação hídrica e a figura 7.1 mostra o ciclo de contaminação viral no meio hídrico. 
Quadro 7.1 - Doenças de veiculação hídrica.

\begin{tabular}{|c|c|c|c|c|c|}
\hline DOENÇA & $\begin{array}{c}\text { AGENTE } \\
\text { ETIOLÓGICO }\end{array}$ & RESERVATÓRIO & MODO DE TRANSMISSÃO & $\begin{array}{l}\text { PERIODO DE } \\
\text { INCUBACXAOO }\end{array}$ & $\begin{array}{l}\text { MEDIDAS DE } \\
\text { PREVENCÃO } \\
\end{array}$ \\
\hline Anebiase & E. histolyzica & Homem & $\begin{array}{l}\text { Transmissão anobucal para as formas vegetativas, através de } \\
\text { alimentos, da água conzaminada e de moscas para as formas } \\
\text { císticus. }\end{array}$ & $\begin{array}{c}2-4 \\
\text { semanas }\end{array}$ & $\begin{array}{l}\text { Água tratada, instalaç̧es } \\
\text { sanitárias, remoçăo do lixo, } \\
\text { controle de moscas, uso de filtros } \\
\text { domésticos. }\end{array}$ \\
\hline Ancilostomiase & $\begin{array}{l}\text { Ancylostoma } \\
\text { duodenale; }\end{array}$ & Homen, gato, cão & Contato com o solo contaminado por formas larvárias infectantes. & $\begin{array}{l}\text { Variável (semanas } \\
\text { ou meses) }\end{array}$ & $\begin{array}{l}\text { Provisăo de água e de instalaçðas } \\
\text { sanitárias, remoģăo do lixo. }\end{array}$ \\
\hline Ascaridiase & humbricoides & Homen & Ingestão de ovos infectantes contidos no solo e nos alimentos. & $4-8$ semanas & $\begin{array}{l}\text { Provisão de água e de instalações } \\
\text { sanitárias adequadas. }\end{array}$ \\
\hline Cólera & Vibrio cholerae & Homem & $\begin{array}{l}\text { Ocorre através de ingestão de água e alimentos contaminados com } \\
\text { fezes ou vômitos de pacientes ou portadores do vibrião da cólera. }\end{array}$ & $\begin{array}{c}2-3 \text { dias } \\
\begin{array}{c}\text { variando de } \\
\text { poucas horas até } 5 \\
\text { dias }\end{array} \\
\end{array}$ & $\begin{array}{l}\text { Saneamento básico (água tratada, } \\
\text { esgoto e remoção de lixo). } \\
\text { Educạão em saúde. }\end{array}$ \\
\hline Esquistossomose & $\begin{array}{l}\text { Schistosoma } \\
\text { mansoni }\end{array}$ & Homem & $\begin{array}{l}\text { Caramujos dulciaquicolas do gênero biomphalaria Constituem a } \\
\text { fonte de infecęäo. Dá-se a transmissão indiratamente, quando as } \\
\text { pessoas, principalmante durante o lazer em ambiantes aquáticos, } \\
\text { entram em contato con as cercarrias eliminadas por planorbideos. }\end{array}$ & $1-2$ meses & 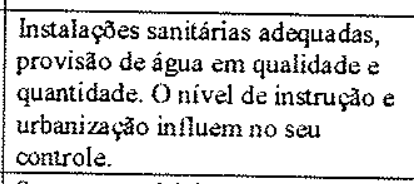 \\
\hline Febretiföide & Salmonella typhi & Honnem & Água, late e outros alimentos contaminados. & $1-3$ semanas & $\begin{array}{l}\text { Saneamento básico. Pasteurização } \\
\text { do leite. } \\
\text { Cozimento adequado dos } \\
\text { alimentos }\end{array}$ \\
\hline Giardiase & Giardia Lamblia & $\begin{array}{l}\text { Homem, possivelmente } \\
\text { algurs animais } \\
\text { domésticos }\end{array}$ & $\begin{array}{l}\text { Agua e alimentos, mãos contaminadas com fezes contendo cistos } \\
\text { de giardia. }\end{array}$ & $\begin{array}{c}7-10 \text { dias } \\
\text { podendo variar } \\
\text { de } 5-24 \text { dias }\end{array}$ & $\begin{array}{l}\text { Água potável para beber e em } \\
\text { quantidade adeguada para a } \\
\text { higiene pessoal e limpeza } \\
\text { doméstica. Uso de filtros e em } \\
\text { casos especiais fervura da água. }\end{array}$ \\
\hline Hepatite (A) & Virus da hapatite A & Homem, drimpanzés & $\begin{array}{l}\text { Agua, leite, vegetais e ostras contaminadas. Contato impessoal } \\
\text { através da contaminaçąo fecal-oral. }\end{array}$ & $\begin{array}{l}15-50 \text { dias } \\
\text { média de } \\
28-30 \text { dias. }\end{array}$ & $\begin{array}{l}\text { Instalaçôes sanitárias adequadas, } \\
\text { água potável. Uso de } \\
\text { imunoglobulina para os contatos } \\
\text { familiares. }\end{array}$ \\
\hline Poliomielite & Poliovinss $1,2,3$ & Homem & 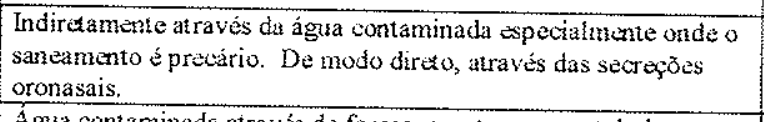 & $\begin{array}{c}3-35 \text { dias } \\
\text { média de } \\
7-14 \text { dias. }\end{array}$ & $\begin{array}{l}\text { Imunizaçaso com a vacina ora! } \\
\text { polivilente. }\end{array}$ \\
\hline Metahemoglobinenia & Nitrato $=45 \mathrm{mg} / \mathrm{L}$ & $\begin{array}{l}\text { Homem } \\
\text { Fertilizantes químicos ou } \\
\text { orgânicos }\end{array}$ & $\begin{array}{l}\text { Agia contaminada através de fossas, esgotos, poços tubulares } \\
\text { construidos inadequadamente e da aplicaçăo de fettilizantes } \\
\text { quimicos ou orgánicos mas culutras. }\end{array}$ & & $\begin{array}{l}\text { Saneamento básico e poços } \\
\text { tubulares adequadamente } \\
\text { construidos. Moderação na } \\
\text { aplicução de fertilizantes. }\end{array}$ \\
\hline
\end{tabular}




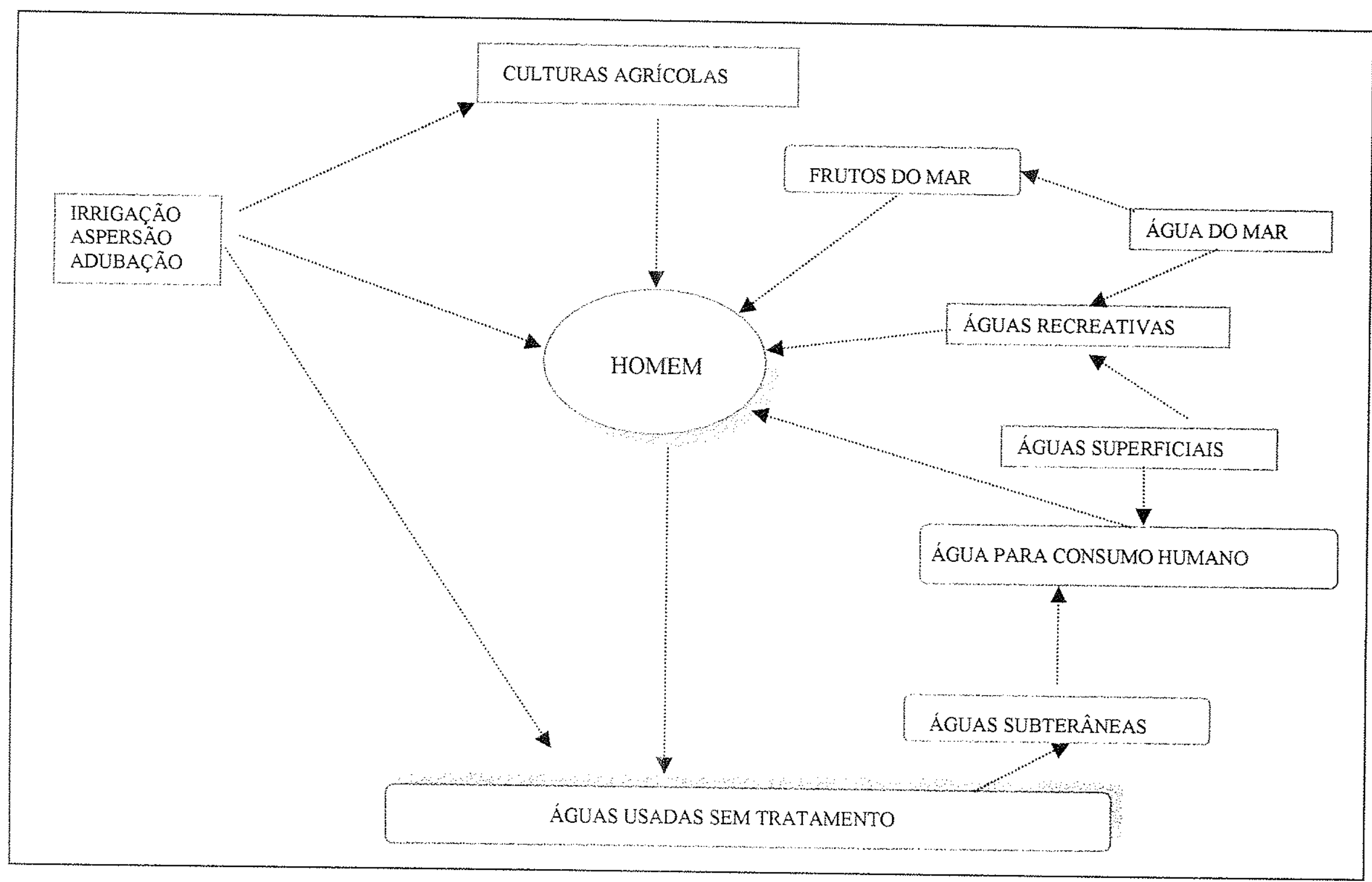

Figura 7.1 - Ciclo de contaminação viral do meio hídrico

Fonte:(CÉCCILLON, 1996) 
A classificação tradicional das doenças relacionadas com a água compreendem dois grupos:

- doenças de transmissão hídrica: são aquelas em que a água atua como veículo do agente infeccioso. Os microorganismos patogênicos atingem a água através dos excretos humanos ou animais infectados, causando problemas principalmente no aparelho intestinal do homem. Essas doenças podem ser causadas por bactérias, fungos, vírus, protozoários e helmintos. O quadro 7.1, apresenta um resumo das características de algumas delas.

- doenças de origem hídrica: são causadas por determinadas substâncias químicas, orgânicas ou inorgânicas, presentes na água em concentrações inadequadas, em geral superiores às especificações nos padrões para águas de consumo humano. Estas substâncias podem existir naturalmente no manancial ou resultarem da poluição.

\section{1 - Indicadores de Saneamento Básico na Bacia do Rio Doce}

Os elementos componentes que interferem na qualidade e funcionalidade dos serviços urbanos de saneamento foram abordados à luz do Plano Estadual de Recursos Hídricos, restringindo-se apenas à cidade de Extremoz, tabela 7.1.

Tabela 7.1 - Principais Indicadores de Saneamento Básico, da cidade de Extremoz

\begin{tabular}{|l|l|}
\hline População & $14,941 \mathrm{hab}$ \\
\hline Taxa de urbanização & $54,7 \%$ \\
\hline Estimativa de habitantes por domić́lio & $4,78 \mathrm{hab} . / \mathrm{dom}$ \\
\hline Domicílios com abastecimento inadequado & $67,6 \%$ \\
\hline Crianças de 0 - 6 anos com abastecimento de água inadequado & $57 \%$ \\
\hline Domićlios com canalização & $32,4 \%$ \\
\hline Abastecimento a partir de poços ou nascente sem canalização & $16,2 \%$ \\
\hline Fossas sépticas sem escoadouros & 88,85 \\
\hline Domicílios servidos pela coleta de lixo & $19,8 \%$ \\
\hline Domicílios com lixo queimado ou enterrado & $53,7 \%$ \\
\hline Domicílios com lixo jogado & $26,1 \%$ \\
\hline Outra forma & $0,4 \%$ \\
\hline
\end{tabular}

Fonte: (SERHID, 1998b)

O levantamento das doenças de veiculação hídrica na bacia hidrográfica em estudo, foi realizado junto à Secretaria de Saúde do Estado e à Fundação Nacional de Saúde (FNS). Na FNS foram levantados os dados relacionados a ocorrência de esquistossomose no periodo de 1976 a 1996, (tabela.7.2). 
Tabela - 7.2 - Registros da ocorrência de esquistossomose na Bacia do Rio Doce, no periodo 1976 - 1996.

\begin{tabular}{|c|c|c|c|c|}
\hline Localidade & Ano & Examinados & Casos Positivos & \begin{tabular}{|c|} 
Prevalência \\
(Pas $/$ Exam $) \times 100$
\end{tabular} \\
\hline Carão & 76 & 119 & 25 & $\begin{array}{r}21,0 \\
\end{array}$ \\
\hline Carão & 77 & 102 & 6 & 5,8 \\
\hline Carão & 78 & 83 & 7 & 8,4 \\
\hline Carăo & 78 & 94 & 5 & 5,3 \\
\hline Carão & 78 & 119 & 3 & 2,5 \\
\hline Carão & 78 & 1.073 & 146 & 13,6 \\
\hline Carão & 79 & 110 & 2 & 1,8 \\
\hline Carão & 79 & 107 & 3 & 2,8 \\
\hline Carão & 79 & 104 & 4 & 3,8 \\
\hline Carão & 81 & 66 & & \\
\hline Carão & 82 & 134 & 1 & 0.74 \\
\hline Carão & 83 & 132 & 2 & 1,5 \\
\hline Carão & 84 & 199 & 2 & 1,0 \\
\hline Carão & 85 & 242 & 2 & 0,8 \\
\hline Carão & 86 & 197 & 19 & 9,6 \\
\hline Carão & 87 & 192 & 16 & 8,3 \\
\hline Carão & 89 & 247 & 15 & 6,0 \\
\hline Carão & 90 & 235 & 8 & 3,4 \\
\hline Carão & 92 & 275 & 4 & 1,4 \\
\hline Carão & 94 & 186 & 2 & 1,0 \\
\hline Carão & 95 & 245 & 1 & \\
\hline Conj. Estrela do Mar & 86 & 1.500 & 18 & 1,2 \\
\hline Conj, Estrela do Mar & 91 & 1.802 & 20 & 1,1 \\
\hline Conj. estrela do Mar & 92 & 1.772 & 9 & 0,5 \\
\hline Conj. Estrela do Mar & 84) & 485 & 10 & 2,0 \\
\hline Conj. Estrela do Mar & 90 & 1.852 & 32 & 1,7 \\
\hline Gramoré & 87 & 76 & 1 & 1,3 \\
\hline Gramoré & 89 & 96 & 7 & 7,2 \\
\hline Gramoré & 90 & 98 & 11 & 11,2 \\
\hline Gramoré & 91 & 113 & 11 & 9,7 \\
\hline Gramoré & 92 & 120 & 19 & 15,8 \\
\hline Gramoré & 93 & 120 & 5 & 4,1 \\
\hline Gramoré & 94 & 119 & 20 & 16,8 \\
\hline Gramoré & 78 & 16 & 2 & 12,5 \\
\hline Gramoré & 79 & 85 & 2 & 2,3 \\
\hline Gramoré & 79 & 3 & & \\
\hline Gramoré & 80 & 125 & 7 & 5,6 \\
\hline Gramoré & 81 & 126 & 2 & 1,5 \\
\hline Gramoré & 82 & 112 & f & \\
\hline Gramoré & 83 & 119 & 4 & 3,3 \\
\hline Gramoré & 84 & 143 & 11 & 7,6 \\
\hline Gramoré & 85 & 103 & 6 & 5,8 \\
\hline Gramoré & 86 & 95 & 15 & 15,7 \\
\hline Gtajiru & 78 & 15 & 2 & 13,3 \\
\hline Guajiru & 78 & 12 & 3 & 25,0 \\
\hline Guajiru & 79 & 76 & 19 & 25,0 \\
\hline Guajiru & 80 & 32 & 4 & 12,5 \\
\hline Guajiru & 81 & 71 & 9 & 12,6 \\
\hline Guajiru & 82 & 62 & 3 & 4,8 \\
\hline
\end{tabular}




\begin{tabular}{|c|c|c|c|c|}
\hline Guajiru & 83 & 61 & & \\
\hline Guajirn & 84 & 73 & & \\
\hline Guajiru & 85 & 45 & 3 & 6,6 \\
\hline Guajiru & 86 & 41 & 3 & 7,3 \\
\hline Guajiru & 87 & 71 & 13 & 18,3 \\
\hline Guajiru & 89 & 71 & 10 & 14.0 \\
\hline Guajiri & 90 & 53 & 3 & 5.6 \\
\hline Guajiru & 91 & 78 & 5 & 6.4 \\
\hline Guajiru & 92 & 76 & 4 & 5,2 \\
\hline Guajiru & 94 & 63 & 10 & 15,8 \\
\hline Lagoa Azul & 78 & 16 & & \\
\hline Lagoa Azul & 79 & 47 & 1 & 2,1 \\
\hline Lagoa Azul & 80 & 31 & & \\
\hline Lagoa Azul & 81 & 28 & & \\
\hline Lagoa Azul & 82 & 42 & 1 & 2.3 \\
\hline Lagoa Azul & 83 & 26 & & \\
\hline Lagoa Azul & 84 & 53 & 4 & 7.5 \\
\hline Lagoa de Extremoz & 76 & 922 & 158 & 17.1 \\
\hline Lagoa de Extremoz & 78 & 22 & 3 & 13,6 \\
\hline Lagoa de Extremoz & 79 & 87 & 16 & 18.3 \\
\hline Lagoa de Extremoz & 80 & 40 & 11 & 27,5 \\
\hline Lagoa de Extremoz & 80 & 1.018 & 25 & 2,4 \\
\hline Lagoa de Extremoz & 81 & 67 & 2 & 2,9 \\
\hline Lagoa de Extremoz & 81 & 257 & 3 & 1,1 \\
\hline Lagoa de Extremoz & 82 & 70 & 3 & 4,2 \\
\hline Lagoa de Extremoz & 83 & 89 & 1 & 1.1 \\
\hline Lagoa de Extremoz & 84 & 223 & 20 & 8.9 \\
\hline Lagoa de Extremoz & 84 & 111 & 5 & 4.5 \\
\hline Lagoa de Extremoz & 85 & 328 & 8 & 2.4 \\
\hline Lagoa de Extremoz & 85 & 96 & 3 & 3,1 \\
\hline Lagoa de Extremoz & 86 & 97 & 11 & 11,3 \\
\hline Lagoa de Extremoz & 87 & 78 & 10 & 12,8 \\
\hline Lagoa de Extremoz & 87 & 1.273 & 110 & 8.6 \\
\hline Lagoa de Extremoz & 89 & 99 & 7 & 7,0 \\
\hline Lagoa de Extremoz & 89 & 1.012 & 58 & 5.7 \\
\hline Lagoa de Extremoz & 90 & 1.564 & 86 & 5,4 \\
\hline Lagoa de Extremoz & 90 & 99 & 16 & 16,1 \\
\hline Lagoa de Extremoz & 91 & 88 & 16 & 18,1 \\
\hline Lagoa de Extremoz & 91 & 1.770 & 54 & 3,0 \\
\hline Lagoa de Extremoz & 92 & 85 & & \\
\hline Lagoa de Extremoz & 92 & 1.898 & 41 & 2,1 \\
\hline Lagoa de Extremoz & 94 & 113 & 15 & 13,2 \\
\hline Lagoa de Extremoz & 94 & 1.948 & 20 & 1,0 \\
\hline Lagoa de Extremoz & 86 & 1.250 & 169 & 13.5 \\
\hline Passagem da Vila & 77 & 62 & 11 & 17.7 \\
\hline Passagem da Vila & 76 & 271 & 82 & 30,2 \\
\hline Passagem da Vila & 78 & 55 & 1) & 1,8 \\
\hline Passagem da Vila & 79 & 77 & 1 & 1.2 \\
\hline Passagem da Vila & 79 & 58 & 4 & 6,8 \\
\hline Passagem da Vila & 79 & 282 & 19 & 6,7 \\
\hline Passagem da Vila & 80 & 126 & 1 & 0,7 \\
\hline Passagem da Vila & 81 & 108 & 1 & 0,9 \\
\hline
\end{tabular}




\begin{tabular}{|c|c|c|c|c|}
\hline Passagem da Vila & 82 & 319 & 6 & $\overline{1,8}$ \\
\hline Passagem da Vila & 83 & 332 & 5 & 1,5 \\
\hline Passagem da Vila & 84 & 415 & 2 & 0,4 \\
\hline Passagem da Vila & 85 & 154 & 2 & 1,2 \\
\hline Passagem da Vila & 86 & 159 & 2 & 1,2 \\
\hline Passagem da Vila & 87 & 137 & 2 & 1,4 \\
\hline Passagem da Vila & 89 & 125 & 3 & 24 \\
\hline Passagem da Vila & 90 & 144 & 3 & 2,0 \\
\hline Passagem da Vila & 91 & 151 & 4 & 2,6 \\
\hline Passagem da Vila & 92 & 141 & & \\
\hline Passagem da Vila & 94 & 148 & 3 & 2,0 \\
\hline Ponta Francesa & 76 & 106 & 31 & 29,2 \\
\hline Ponta Francesa & 77 & 12 & & \\
\hline Ponta Francesa & 78 & 23 & & \\
\hline Ponta Francesa & 79 & 25 & & \\
\hline Ponta Francesa & 79 & 112 & 9 & 8,0 \\
\hline Ponta Francesa & 79 & 24 & & \\
\hline Ponta Francesa & 80 & 59 & 1 & 1,6 \\
\hline Ponta Francesa & 81 & 21 & & \\
\hline Ponta Francesa & 82 & 121 & 4 & 3.3 \\
\hline Ponta Francesa & 83 & 111 & 12 & 10,8 \\
\hline Ponta Francesa & 84 & 144 & & \\
\hline Ponta Francesa & 85 & 48 & 6 & 12.5 \\
\hline Ponta Francesa & 86 & 56 & 6 & 10,7 \\
\hline Ponta Francesa & 87 & 58 & 2 & 3,4 \\
\hline Ponta Francesa & 87 & 59 & 7 & 11,8 \\
\hline Ponta Francesa & 89 & 118 & 12 & 10,1 \\
\hline Ponta Francesa & 90 & 165 & 12 & 7,2 \\
\hline Ponta Francesa & 90 & 69 & 1 & 1,4 \\
\hline Ponta Francesa & 91 & 160 & 8 & 5,0 \\
\hline Ponta Francesa & 91 & 63 & 2 & 3.1 \\
\hline \begin{tabular}{|l|} 
Ponta Francesa \\
\end{tabular} & 92 & 85 & 1 & 1,1 \\
\hline Ponta Francesa & 92 & 169 & 2 & 1.1 \\
\hline Ponta Francesa & 94 & 156 & 5 & 3,2 \\
\hline Ponta Francesa & 94 & 64 & 1 & 1,5 \\
\hline Ponta Grosa & 77 & 119 & 53 & 44.5 \\
\hline Ponta Grossa & 78 & 11 & & \\
\hline Ponta Grossa & 78 & 12 & & \\
\hline Ponta Grossa & 79 & 54 & 2 & 3,7 \\
\hline Ponta Grossa & 79 & 97 & 21 & 21,6 \\
\hline Ponta Grossa & 80 & 34 & & \\
\hline Ponta Grossa & 80 & 58 & 1 & 1.7 \\
\hline Ponta Grossa & 81 & 42 & 9 & 21,4 \\
\hline Ponta Grossa & 81 & 55 & 5 & 9,0 \\
\hline Ponta Grossa & 82 & 128 & 3 & 2.3 \\
\hline Ponta Grossa & 82 & 87 & 2 & 2.2 \\
\hline Ponta Grossa & 83 & 126 & 6 & 4.7 \\
\hline Ponta Grossa & 83 & 87 & & \\
\hline Ponta Grossa & 84 & 106 & 16 & 15,0 \\
\hline Ponta Grossa & 84 & 158 & 49 & 31.0 \\
\hline Ponta Grossa & 85 & 173 & 41 & 23,6 \\
\hline Ponta Grossa & 85 & 109 & 20 & 18,3 \\
\hline
\end{tabular}




\begin{tabular}{|l|r|r|r|r|}
\hline Ponta Grossa & 86 & 135 & 62 & 45,9 \\
\hline Ponta Grossa & 86 & 106 & 39 & 36,7 \\
\hline Ponta Grossa & 87 & 79 & 17 & 21,5 \\
\hline Ponta Grossa & 87 & 138 & 51 & 36,9 \\
\hline Ponta Grossa & 89 & 96 & 10 & 10,4 \\
\hline Ponta Grossa & 89 & 136 & 36 & 26,4 \\
\hline Ponta grossa & 90 & 149 & 24 & 16,1 \\
\hline Ponta Grossa & 90 & 70 & 5 & 7,1 \\
\hline Ponta Grossa & 91 & 149 & 16 & 10,7 \\
\hline Ponta Grossa & 91 & 92 & 8 & 8,6 \\
\hline Ponta Grossa & 92 & 136 & 12 & 8,8 \\
\hline Ponta Grossa & 92 & 78 & 7 & 8,9 \\
\hline Ponta grossa & 93 & 159 & 8 & 5,0 \\
\hline Ponta Grossa & 93 & 62 & 1 & 1,6 \\
\hline Ponta Grossa & 94 & 133 & 16 & 12,0 \\
\hline Ponta Grossa & 94 & 74 & 3 & 4,0 \\
\hline
\end{tabular}

Fonte: (FNS)

Na Subcoordenadoria de Notificação Compulsória e Agravos Específicos da Secretaria de Saúde do Estado do Rio Grande do Norte, foram levantados os dados relacionados à ocorrência de febre tifóide, hepatite viral, cólera e esquistossomose, conforme as tabelas 7.3 e 7.4 .

Tabela 7.3 - Casos notificados de doenças de veiculação hídrica na bacia do rio Doce, no período de 1989 a março de 1991

\begin{tabular}{|l|r|r|r|r|r|r|r|r|r|r|r|r|}
\hline & 1989 & 1990 & 1991 & 1992 & 1993 & 1994 & 1995 & 1996 & 1997 & 1998 & $\begin{array}{l}\text { março } \\
1999\end{array}$ & \multicolumn{1}{|c|}{ Total } \\
\hline Febre tifóide & 01 & 01 & 02 & - & 01 & - & - & - & - & - & - & 05 \\
\hline Hepatite viral & - & - & - & - & 64 & 76 & 40 & 46 & 117 & 94 & 07 & 444 \\
\hline *Esquistossomose & & & & & & & & & 29 & 34 & 05 & 68 \\
\hline
\end{tabular}

Fonte (Secretaria de Saúde do Estado do Rio Grande do Norte)

Tabela 7.4 - Casos confirmados de doenças de veiculação hídrica na bacia do rio Doce, no período de 1992 a março de 1999

\begin{tabular}{|l|r|r|r|r|r|r|r|r|r|}
\hline & 1992 & 1993 & 1994 & 1995 & 1996 & 1997 & 1998 & marco/1999 & Total \\
\hline Cólera & 66 & 101 & 154 & - & 02 & - & - & - & 323 \\
\hline Hepatite viral & - & - & - & - & - & 09 & 23 & 01 & 33 \\
\hline *Gocquistossomose & & & & & & 28 & 34 & 05 & 67 \\
\hline
\end{tabular}

Fonte: (Secretaria de Saúde do Estado do Rio Grande do Norte)

\section{2 - Esquistossomose}

A esquistossomose é uma doença parasitária produzida por esquistossoma (trematódeo), na qual as larvas adultas, macho e fềmea, vivem nas veias mesentéricas e/ ou vesiculares do hóspede durante vários anos. A sintomatologia depende da localização do 
parasita. Os efeitos patológicos são as complicações derivadas da infecção crônica: fibrose hepática e hipertensão portal. As larvas de algumas outras espécies de esquistossomo de aves e mamíferos podem penetrar na pele humana e produzir uma dermatite conhecida como "prurido dos nadadores". O agente infeccioso é o Schistosoma mansoni e Schistosoma Japonicum.

No período de 1976 a 1996 a Fundação Nacional de Saúde registrou no município de Extremoz 2.267 casos positivos de esquistossomose, tabela 7.2.

A figura 7.2 mostra o comportamento da ocorrência dos casos positivos de esquistossomose nas diversas localidades nas proximidades da lagoa de Extremoz.

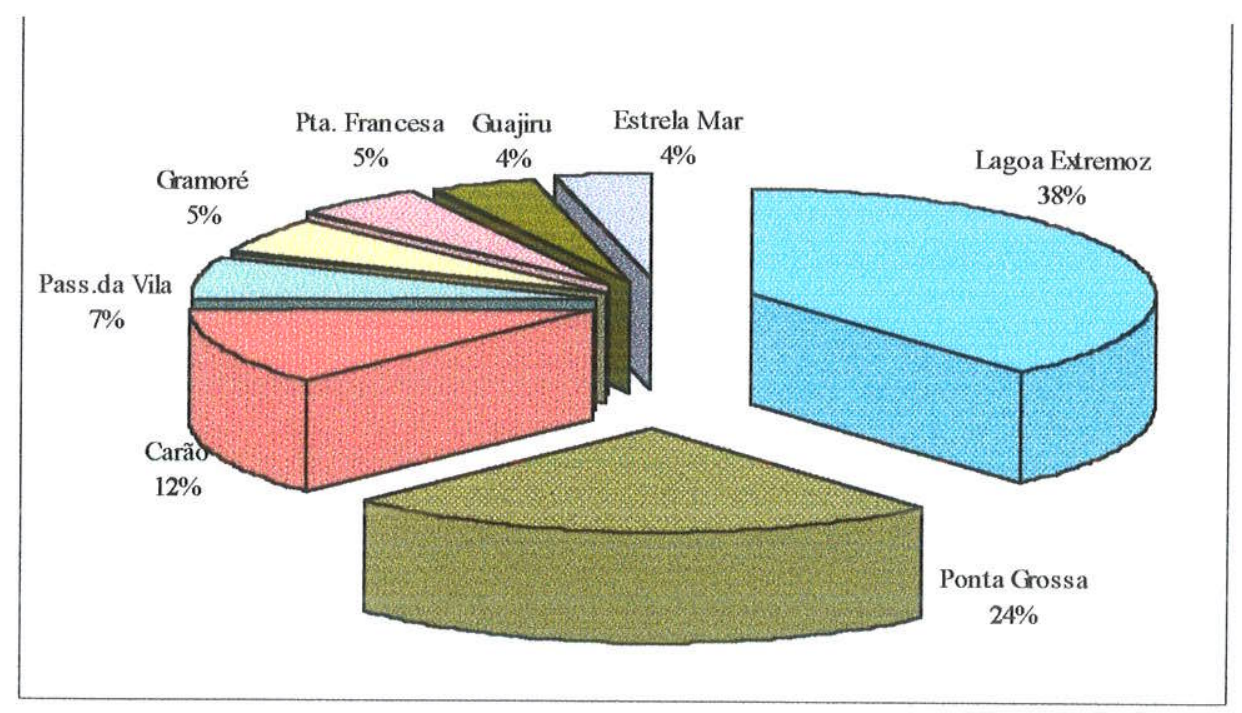

Figura 7.2 - Casos de ocorrência de esquistossomose na Bacia do rio Doce Fonte: (FNS, 1976 a 1996)

\section{3 - Hepatite Viral}

A hepatite viral é uma infecção sistêmica aguda que afeta, predominantemente, o fígado e se apresenta sob duas formas devidas a agentes etiológicos estreitamente relacionados, mas distintos, conhecidos, respectivamente como vírus A e B. O tipo A é conhecida como hepatite infecciosa ou epidêmica, pode ser transmitida ao homem por via oral ou parenteral e o tipo B é transmitida apenas por via parenteral.

A hepatite viral tipo A pode ocorrer tanto sob forma esporádica como epidêmica e compreende um período de incubação variável, entre duas a seis semanas. Ocorre particularmente sob condições de má higiene, em mananciais de águas contaminadas por fezes. As ocorrências se dão principalmente em acampamentos de verão, parques muito 
freqüentados em certas estações do ano ou aglomerados de pessoas em abrigos de inverno e balneários onde não existam condições sanitárias adequadas. Caracteriza-se por distúrbios digestivos e comprometimento do estado geral.

Na bacia do rio Doce foram notificados 444 casos no período de 1993 a março de 1999, tendo sido confirmados 33 casos no período de 1997 a março de 1999, (tabelas 7.3 e 7.4). A figura 7.3 mostra o comportamento dos casos notificados de hepatite viral no período de 1993 a março de 1999.

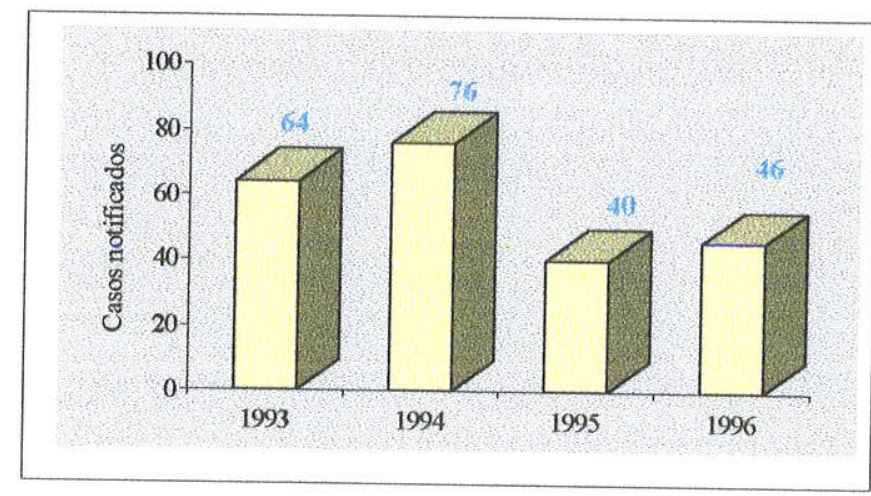

Figura 7.3 - Casos notificados de hepatite viral no período de 1993 a 1996.

Fonte:(Secretaria de Saúde do Estado do RN).

\section{4 - Cólera}

A cólera é uma enfermidade aguda, diarréica, provocada por uma infecção intestinal através da bactéria Vibrio cholerae. A infecção geralmente é benígna e assintomática, as vezes, pode ser grave. Aproximadamente uma de cada 20 pessoas infectadas pode ter a enfermidade em estado grave, caracterizada por diarréia aquosa profunda, vômitos e intensa depleção salina. Nestas pessoas, há uma perda rápida de líquido corporal e leva a desidratação e a prostação. Sem tratamento adequado, pode ocorrer a morte em questão de algumas horas.

A cólera tem sido pouco freqüente nos países desenvolvidos durante os últimos 100 anos; no entanto esta enfermidade é comum em outras partes do mundo, incluindo os países da América Latina, o sul do Saara na África e a Índia.

Nos Estados Unidos, a cólera foi comum nos anos 1800, pois foi praticamente eliminado graças aos modernos sistemas sanitários e de tratamento de água. Atualmente os poucos casos confirmados no país se deve ao fato das pessoas contraírem a cólera durante viagens para a América Latina, África ou Ásia. 
LÓPEZ (1998) descreveu o comportamento da cólera no Peru, com base nos dados do Sistema de Vigilância deste país, abrangendo casos hospitalizados de óbitos por semanas epidemiológicas. Foram também incluídos, neste estudo, resultados de trabalhos realizados durante a epidemia com o objetivo de identificar fatores de risco. As informações foram analisadas segundo características do tempo, espaço e pessoa. A incidência e as taxas de mortalidade e de letalidade dos casos hospitalizados foram analisadas por semanas epidemiológicas, referentes ao período de 1991 a 1993. Os estudos constataram que a disseminação da cólera pelo território peruano esteve relacionada com fatores sociais, culturais, econômicos e geográficos.

As curvas epidêmicas analisadas indicaram as formas de transmissão predominantes e possíveis fatores associados: consumo de água contaminada, consumo de frutas ou verduras sem cuidados de higiene, consumo de alimentos distribuídos por vendedores ambulantes, consumo de gelo produzido com água contaminada e costumes relativos às formas de elaborar alimentos no domicílio. Identificou-se como fatores de proteção, ferver a água e o tipo de serviço de fornecimento de água intra-domiciliar.

$\mathrm{Na}$ bacia do Rio Doce foram registrados e confirmados 323 casos no período de 1992 a 1996.

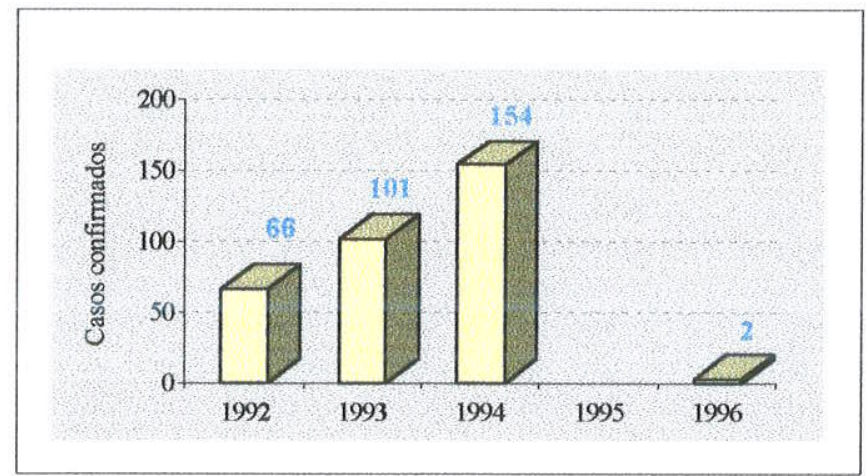

Figura 7.4 - Casos confirmados de cólera no período de 1992 a 1996.

Fonte:(Secretaria de Saúde do Estado do RN)

\section{5 - Febre Tifóide}

A febre tifóide é uma infecção sistêmica desenvolvida através da ingestão de água, leite ou alimentos contaminados por fezes infectadas pela Salmonella typhosa que reside apenas no homem e é perpetuada na natureza pela sua transmissão a pessoas sadias, por 
doentes ou portadores. É um axioma epidemológico que, para cada surto ou caso esporádico de febre tifóide deve haver um portador.

A incidência de febre tifóide nos E.U.A. declinou no último século, devido principalmente ao controle da atividade dos portadores, e a melhoria do suprimento de água e dos serviços de esgotos. Grandes epidemias sucederam na década de sessenta na Suíça e GrãBretanha, acentuando a capacidade de disseminação devido as deficiências nos serviços de saneamento.

De acordo com as informações prestadas pela Secretaria de Saúde do Estado foram cinco os casos notificados de febre tifóide no período de 1989 a 1993.

\section{6 - Patogenicidade do Íon Nitrato}

A patogenicidade das águas contendo elevados teores de nitrato, é maior nas crianças na faixa etária de 0 a 6 meses, segundo CATALAN (1981) (apud FIGUEREDO et al. 1992). A explicação para essa susceptibilidade é que no meio gástrico das crianças prolifera uma flora bacteriana redutora, a qual propicia a redução de $\mathrm{NO}_{3}^{-}$para $\mathrm{NO}_{2}^{-}$. A sintomatologia dessa contaminação caracteriza-se por cianose (cor azulada da pele), cefaléia, vertigens e taquicardia. Constatou-se que os adultos são menos vulneráveis a metahemoglobinemia que

as crianças. Porém há ainda a possibilidade da reação dos nitritos com aminas nos intestinos, produzindo nitrosaminas que são substâncias carcinogênicas.

A abordagem da presença do nitrato nas águas subterrâneas da bacia do rio Doce, (capítulo5, Item 5.2.3), mostra que os teores de nitrato crescem a partir de um nível geral de base de $10 \mathrm{mg} / \mathrm{L}$ na parte leste da área, em direção aos conjuntos habitacionais da zona norte de Natal, atingindo valores da ordem de $80 \mathrm{mg} / \mathrm{L}\left(\mathrm{NO}_{3}{ }_{3}\right)$. Na parte oeste da bacia onde concentram-se cacimbões de profundidades (14 metros), as concentrações de nitrato atingem $55,09 \mathrm{mg} / \mathrm{L}$.

\subsection{Saúde Pública no Contexto do Gerenciamento dos Recursos Hídricos}

A questão do gerenciamento dos recursos hídricos não pode limitar-se apenas aos aspectos quantitativos e qualitativos das águas, mas deve incluir a promoção da saúde pública no que se refere ao controle e prevenção das doenças de veiculação hídrica.

Saude Pública é a ciência e a arte de prevenir as doenças, prolongar a vida, promover a saúde e a eficiência física e mental, mediante esforços organizados da 
comunidade. ROUQUAYROL (1993), analisando o enfrentamento das questões da saúde pública enfatiza: a prevenção deve começar ao nível das estruturas políticas e econômicas. As ações dos especialistas da saúde só são eficientes a partir do momento em que as situações sócio-político-econômicas estão corrigidas. Em sua análise, a autora comenta o texto de Rossi Doria, médico italiano que em 1904 já pregava a indissociabilidade da ação política e da ação sanitária, assim dizia o texto: "o que é que pode fazer um individuo isolado para defender-se de um ambiente que o ameaça continuamente de todo lado"?

$\mathrm{Na}$ bacia em questão, especificamente no seu curso inferior foram diagnosticados alguns casos de doenças de veiculação hídrica como: esquistossomose, cólera, febre tifóide e hepatite viral. Também foi constatado que o potencial hídrico subterrâneo, do curso inferior da bacia, está fortemente submetido aos efeitos impactantes da falta de saneamento, cujas conseqüências já se faz presente nas águas de alguns poços tubulares, onde os teores de nitrato já ultrapassam $45 \mathrm{mg} / \mathrm{L}$, limite estabelecido pela Organização Mundial de Saúde.

Considerando que a respectiva bacia já detém um dos pólos industriais mais promissores e com tendência a se expandir nos próximos anos, consequentemente acompanhado de uma crescente urbanização, além do desenvolvimento turístico é imprescindivel que ao se fazer gerenciamento dos recursos hídricos se inclua a componente saúde pública.

O reconhecimento da complexidade da situação no Brasil, tanto em relação aos problemas de saúde da população (perfil epidemiológico) quanto àqueles referentes ao sistema de saúde, não significa uma impossibilidade absoluta de enfrentá-la. As intervenções necessárias para a melhoria dos níveis sanitários e para a garantia do acesso oportuno aos serviços de saúde dependem de medidas técnicas e administrativas, porém exigem mudanças de ordem econômica, política e cultural. Consequentemente, o enfrentamento da situação de saúde requer intervenções setoriais no âmbito da organização dos serviços de saúde e extra setoriais, que envolvam outros setores, tais como educação, agricultura, habitação, recursos hídricos, saneamento e outros, (CNS, 1987).

A reforma sanitária constitui uma proposta abrangente de mudança social no Brasil e, ao mesmo tempo, um processo de transformação da atual situação sanitária (AROUCA, 1988). A proposta da reforma sanitária foi gestada ao longo das últimas décadas a partir de críticas e estudos referentes ao sistema de saúde vigente e através de movimentos sociais envolvendo estudantes, profissionais de saúde, docentes, pesquisadores, sindicatos de trabalhadores e associações de moradores (PAM (1993) apud ROUQUAYROL 1993). 
Em 1986, os princípios e diretrizes da reforma sanitária foram sistematizados na $8^{a}$ Conferência Nacional de Sáude (CNS, 1987), destacando-se os seguintes elementos:

- conceito ampliado de saúde;

- reconhecimento de saúde como direito de todos e dever do Estado;

- sistema único de saúde;

- participação popular;

- constituição e ampliação do orçamento social.

Esta nova concepção possibilitaria intervenções específicas no âmbito do sistema de serviços de saúde, além de exigir medidas mais amplas extra setoriais. Apesar de certos avanços alcançados na legislação e em experiências localizadas e descentralizadas de saúde a reforma sanitária tem encontrado grandes resistências para a sua concretização (ROUQUAYROL, 1993)

No Brasil, convivem de forma contraditória ou complementar o modelo "assistencial sanitarista" e o modelo médico "assistencial privatista".

O primeiro corresponde à Saúde Pública tradicional que não contempla a totalidade da situação de saúde, isto é, concentra sua atenção no controle de certos agravos ou em determinados grupos supostamente em risco de adoecer. Geralmente deixam de se preocupar com os problemas do sistema de saúde e com os determinantes mais gerais da situação sanitária. PAIM (1993) apud ROUQUAYROL (1993), analisando este modelo concluiu que muitas vezes as campanhas de saúde pública aparentam uma operação militar visando ao combate de uma epidemia (cólera por exemplo). É quase um trabalho do tipo "apagar incêndio".

Diante desta problemática vêm sendo propostos e elaborados, modelos assistenciais alternativos visando a integralidade da atenção e ao impacto sobre os problemas de saúde. Essas experiências localizadas iniciaram-se com a implantação do SUDS em alguns estados, como Bahia, São Paulo, Rio Grande do Norte, entre outros, através da organização de distritos sanitários. Na verdade, estes modelos requerem uma mudança na organização e funcionamento de instituições. PAIM (1993) apud ROUQUAYROL (1993), sugere que as secretarias de saúde não deveriam concentrar seus esforços apenas na oferta de serviços para os usuários que constituem a "demanda espontânea", mas deveriam atentar fundamentalmente para as necessidades de saúde da população num dado "território" e para o impacto sobre as mesmas. É dentro desta visão que a problemática da Saúde Pública, relacionada às doenças de veiculação hídrica, precisa ser analisada diante dos órgãos responsáveis pela saúde, pelos 
recursos hídricos e pela qualidade ambiental. Com essa visão, propõe-se que o gerenciamento das águas da Bacia do Rio Doce adote o denominado "território", como sendo a bacia hidrográfica a unidade de gerenciamento para as doenças de veiculação hídrica.

A qualidade fisica e química das águas dependem de diversos fatores, tais como aspectos geológicos, estruturais e do comportamento da drenagem da bacia hidrográfica. Quanto aos aspectos bacteriológicos, microbiológicos e da presença de elementos tóxicos, nas águas, estes fatores estão fortemente ligados ao uso e ocupação do solo da bacia hidrográfica. Neste sentido é de se esperar que os tipos de doenças de veiculação hídrica também estejam associados ao comportamento de uma determinada bacia hidrográfica. Por exemplo, no caso da bacia do rio Doce a incidência de esquistossomose foi diagnosticada no curso inferior da bacia, devido a presença das lagoas e vales úmidos. Na montante da bacia onde existe escassez de água as doenças persistentes são transmitidas pelas verminoses devido à falta de água para a higiene. Desta forma, o gerenciamento dos recursos hídricos de uma determinada bacia, deve contemplar uma visão holística com ações localizadas.

ROUQUAYROL (1993) define espaço geográfico como sendo uma determinada porção localizada da superficie terrestre, constituidas pelas rugosidades, águas correntes e estanques, solo, clima, fauna e flora, ocupada, modificada e organizada por uma população socialmente estruturada, acrescida dos resultados objetivos da intervenção do homem no decurso da história. Os elementos do espaço geográfico que se põem ao observador constituem a paisagem. Assim, a paisagem nada mais é do que o reflexo do espaço. Seu aspecto, a um dado momento, é resultante da confluência das seguintes contribuições essenciais: (i) dos condicionantes básicos, físicos, químicos e morfológicos, formadores do substrato abiótico; (ii)da existência e dinamismo do componente biótico formado pela flora e pela fauna; (iii) da atuação do homem em decorrência de suas necessidades sociais e econômicas.

São vários os estudos de investigação epidemiológica nos quais os autores procuram evidenciar associações significativas entre incidência ou prevalência de doenças, e com variáveis ambientais (localização, relevo, hidrografia, solo, clima, vegetação e fauna).

No modelo atual, baseado na "demanda espontânea", o sistema de saúde, espera que um indivíduo com esquistossomose por exemplo, sinta "algo errado em sua saúde" e tenha a iniciativa de procurar um serviço que se disponha a atendê-lo. Nessa nova perspectiva estará se implantando um modelo que contemplará à integralidade do indivíduo com o meio ambiente e que tem como princípio básico a prevenção das doenças de veiculação hídrica, em que os problemas deverão ser identificados nas comunidades através de um trabalho conjunto 
com as associações de usuários dos recursos hídricos. A conscientização dos usuários em relação ao uso dos recursos hídricos deverá ser de uma forma holística, ou seja, o usuário deve ter uma visão de como usar a água como recurso natural de valor econômico e tê-la como um veículo de saúde.

Dentro deste contexto pensar globalmente e agir localmente através das associações dos usuários dos recursos hídricos em parceria com o setor de saúde pública e o setor de saneamento poderá ser um forte instrumento para enfrentar as questões relacionadas a esta problemática.

Nessa perspectiva as sugestões para o gerenciamento dos recursos hídricos considera a componente saúde pública parte deste modelo.

Sendo assim, apresentamse como sugestão que o trabalho a ser desenvolvido pelo órgão gestor dos recursos hídricos através da Associação dos Usuários dos Recursos Hídricos, aborde principalmente a importância e a necessidade do saneamento, para que os usuários dos recursos hídricos da referida bacia hidrográfica se conscientizem de tal necessidade e passem a cobrar do poder público e/ou dos respectivos setores a existência destes serviços. Cabe à comunidade questionar se suas instituições sociais e econômicas são favorecedoras de saúde ou de doença. No entanto, diante da falta de conhecimento, de educação e acesso às informações as comunidades carentes não estão preparadas para possuir esta visão.

Dentro deste contexto propõe-se que a associação dos usuários dos recursos hídricos em conjunto com os setores envolvidos nas questões de saúde pública, desenvolvam trabalhos educacionais a nível de bacia hidrográfica, aplicando a educação ambiental, o conhecimento do comportamento dos corpos d'água da bacia e o acompanhamento da incidência das doenças de veiculação hídrica na região em apreço.

No caso específico da Bacia do Rio Doce, será de grande relevância, que seja realizado um trabalho desse tipo, com a participação das comunidades. A bacia apresenta excelentes condições para a implantação de um modelo experimental dessa natureza. Possui uma área relativamente pequena em relação as outras bacias, $\left(338 \mathrm{~km}^{2}\right.$, equivalente a $0,64 \%$ da superfície do estado), tornando mais fácil o gerenciamento dessas questões. Apresenta um comportamento hidrogeológico e do uso e ocupação do solo bastante diversificados. É uma bacia, que do ponto de vista sócio-econômico, é considerada uma das mais promissoras do estado, pois detêm um dos pólos industriais mais importantes e está inserida na rota "litoral norte", onde o desenvolvimento turístico está em ascensão.

Com base na realidade sócio-econômica da bacia, sugere-se que este trabalho tenha raizes nas escolas da região. Os professores participantes deste projeto, serão 
devidamente orientados e acompanhados por equipes técnicas dos órgãos responsáveis pelas questões da saúde pública e da gestão dos recursos hídricos.

Este trabalho poderá ser realizado em três domínios da bacia, tendo em vista a variação climática, as diferenças de uso e ocupação do solo nestes domínios. Portanto, poderão ser envolvidas três equipes: para os cursos superior, médio e inferior da bacia. $O$ intuito maior deste trabalho será de envolver a escola, que orientará o usuário dos recursos hídricos a entender o comportamento dos corpos d'água e suas inter-relações e a partir daí sedimentar a conscientização do uso dos recursos hídricos como veículo de saúde. Os resultados deste projeto deverão ser permanentemente divulgados para todos os usuários da bacia através da associação dos usuários. Neste sentido, este trabalho deverá ter continuidade, de modo que à medida que uma determinada equipe conclua um ciclo de monitoramento, deverá de imediato repassar os trabalhos para outra equipe dar continuidade ao projeto. $O$ conhecimento do comportamento dos corpos d'água compreenderá o acompanhamento dos níveis das águas superficiais e subterrâneas e da qualidade física e química das águas. Em conjunto com o setor de saúde deverão ser efetuadas as análises microbiológicas para auxiliar no diagnóstico e prevenção das doenças de veiculação hídrica. As equipes técnicas do setor de saúde em conjunto com o órgão gestor dos recursos hídricos deverão fazer um criterioso acompanhamento principalmente dos casos de verminoses, esquistossomose, hepatite viral e cólera, realizando estudos que compreendam o cruzamento das informações sobre a incidência das doenças e dos dados do monitoramento dos corpos d'água da bacia. Os resultados deste projeto deverão ser divulgados a nível regional, como "modelo experimental" e a partir dai ser implementado nas outras bacias hidrográficas cuja realidade é mais complexa.

Com esta visão, a aplicação deste modelo de gerenciamento integrado dos recursos hídricos, estará propiciando valiosa contribuição na promoção da saúde, por se enquadrar na prevenção primária, ou seja: possibilitar a prevenção que se faz com a intercepção dos fatores pré-patogênicos, que inclui os seguintes fatores relacionados ao meio ambiente e consequentemente aos recursos hídricos:

- Promoção de Saúde: educação sanitária, água com qualidade e quantidade adequada.

- Proteção Específica - saneamento básico (tratamento da água, esgotos e lixo) e higiene pessoal e do lar.

O quadro 7.2 , representa a história natural e prevenção de doenças, com base em LEAVEL \& CLARK (1976). 
Quadro 7.2 - História natural e prevenção de doenças

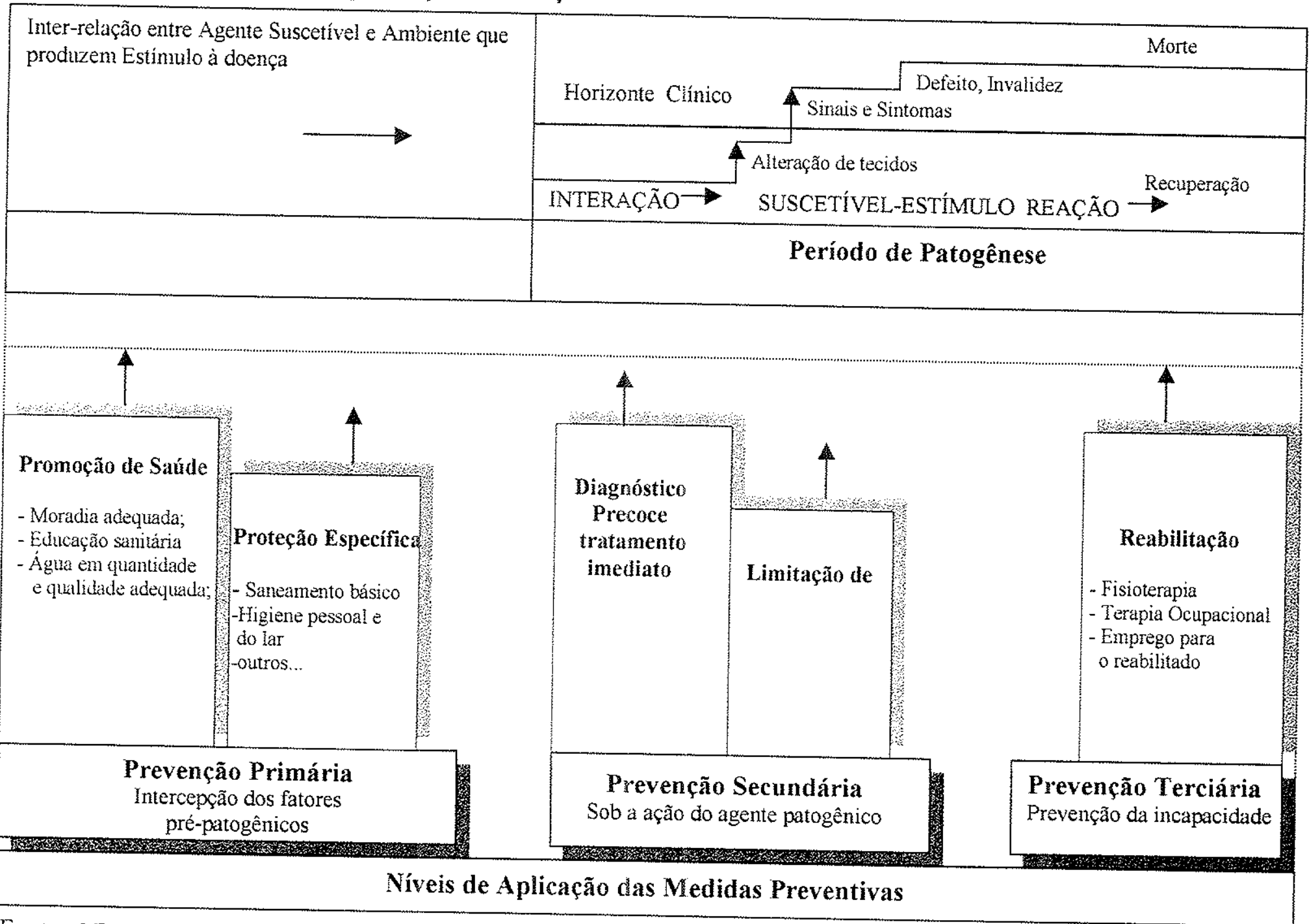

Fonte:( LEAVEL \& CLARK, 1976) 


\section{0 - APROVETTAMENTO, USOS, DEMANDA E OFERTA DOS RECURSOS
HÍDRICOS}

\subsection{Aproveitamento}

$\mathrm{O}$ aproveitamento dos recursos hídricos na bacia do rio Doce, é expressivo no curso inferior através da captação das águas da lagoa de Extremoz e do sistema aqüífero Dunas/Barreiras.

Na lagoa de Extremoz, à margem esquerda, (figura 8.1), a captação adentra aproximadamente 140 metros, onde uma torre de concreto armado abriga os conjuntos elevatórios constituídos por três bombas do tipo centrífugas de eixo vertical, acionadas por motor elétrico de $200 \mathrm{CV}$. As bombas estão imersas na lagoa, onde se dá a sucção da água bruta aduzindo até a estação de tratamento (ETA), através de tubulação de ferro fundido de 800 milimetros de diâmetro e aproximadamente 950 metros de comprimento. Cada bomba tem capacidade para aduzir uma vazão de $3331 / \mathrm{s}$ e segundo informações da CAERN, (agosto de 1999), é captado atualmente um volume de $6341 / \mathrm{s}$ equivalente a $20 \times 10^{6} \mathrm{~m}^{3} / \mathrm{ano}$.

A Estação de Tratamento é do tipo convencional composta das unidades de coagulação, floculação, decantação, filtração e desinfecção. Passado pelo processo de tratamento a água é conduzida ao reservatório localizado nos domínios da ETA, ligando-se ao poço de sucção da estação elevatória de água tratada, onde nove conjuntos motor-bomba fazem a adução para os reservatórios de distribuição nos bairros da zona norte de Natal. No laboratório são realizados os controles de qualidade, cor, turbidez, cloro residual, $\mathrm{pH}$ e oxigênio consumido.

Quanto ao aproveitamento das águas subterrâneas, é realizado através de poços tubulares profundos e de poços amazonas. Entre os 275 pontos de captação de água subterrânea cadastrados, 188 são poços e 87 são poços amazonas, (figura 8.2).

Os pontos cadastrados concentram-se principalmente nos municípios de Extremoz (38\%) e São Gonçalo do Amarante (24\%). Nos municípios de Natal e Ceará Mirim compreendem respectivamente $16 \%$ e $17 \%$ dos pontos. Os $5 \%$ restantes encontram-se distribuidos na montante da bacia entre os municípios de Ielmo Marinho (4\%) e Taipu (1\%), (figura 8.3)

A forma da distribuição espacial a nivel de bacia hidrográfica dos pontos cadastrados, figura 8.4, apresenta-se indicando uma forte relação com as características hidrogeológicas e sócio-econômicas da região. De modo que, à montante da bacia, onde predominam as rochas do embasamento cristalino, a quantidade de poços é significativamente 


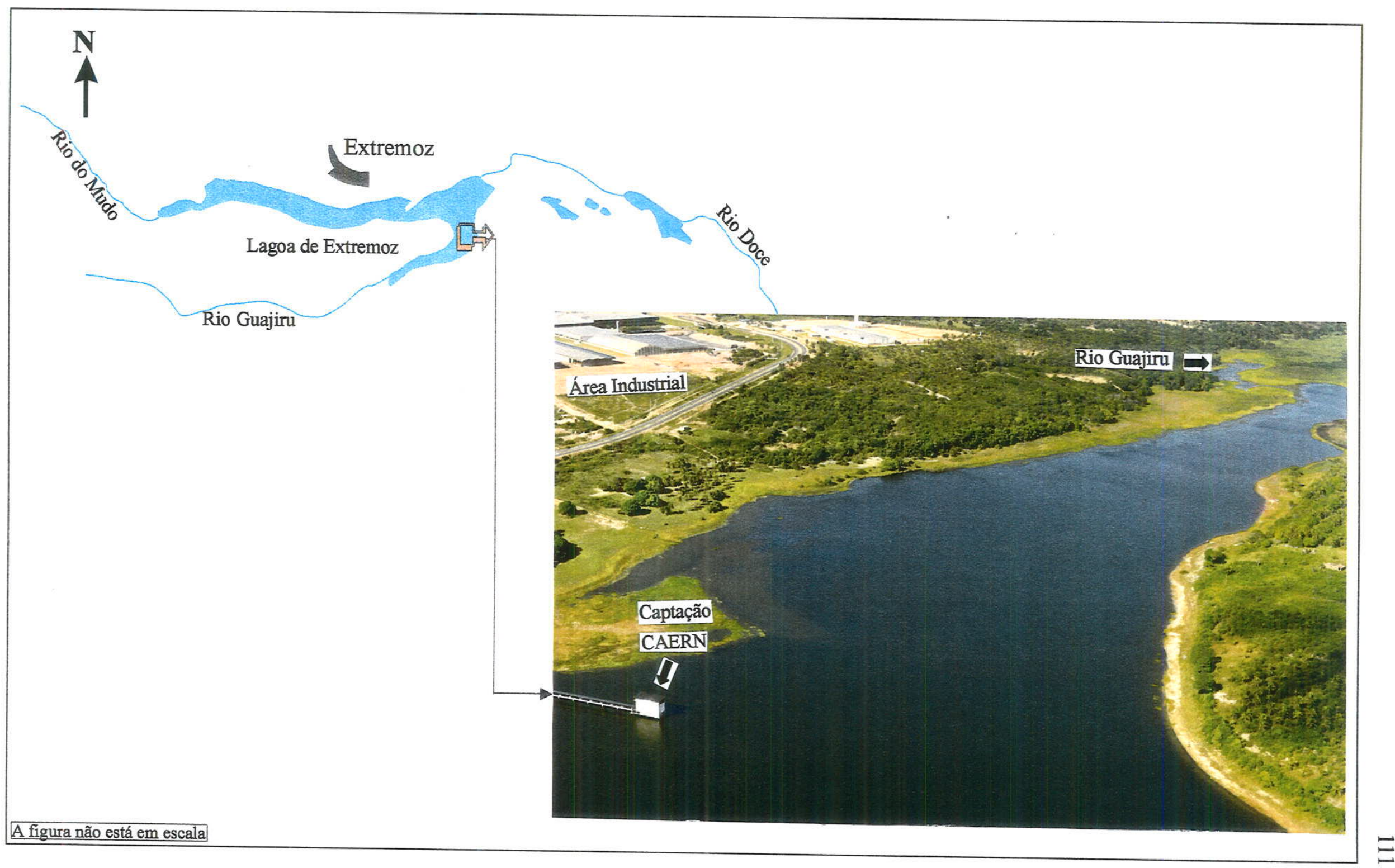

Figura 8.1 - Localização da captação da CAERN na Lagoa de Extremoz Fonte: (CASTRO, 2000) 
inferior, havendo uma maior predominância de cacimbões, que são construídos em coberturas sedimentares e aluvionares com profundidades médias de 14 metros, com uso especificamente para consumo humano. As informações sobre as estruturas hídricas cadastradas (poços tubulares e cacimbões), indicaram que as vazões explotadas neste setor variam entre 0,5 a 3,0 $\mathrm{m}^{3} / \mathrm{h}$.

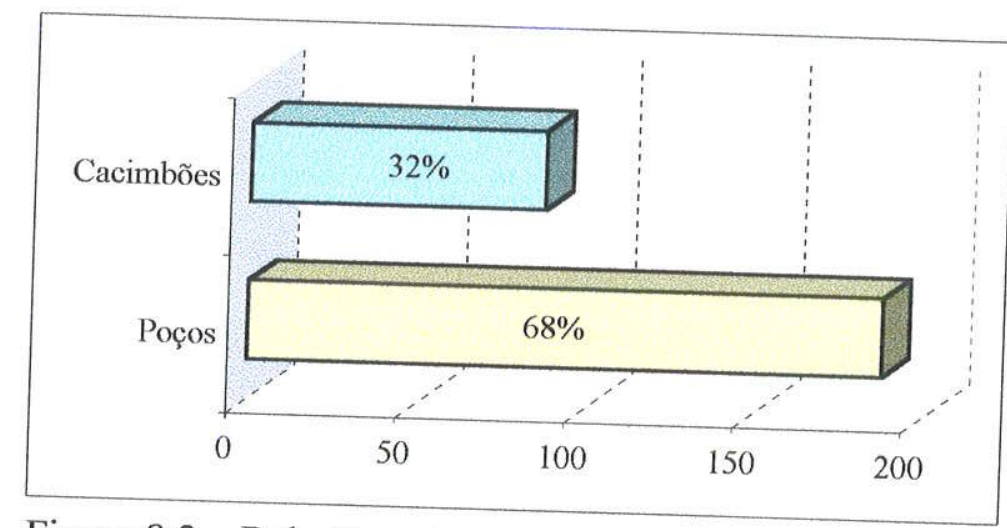

Figura 8.2 - Relação entre poços e cacimbões cadastrados Fonte: (CASTRO, 2000)

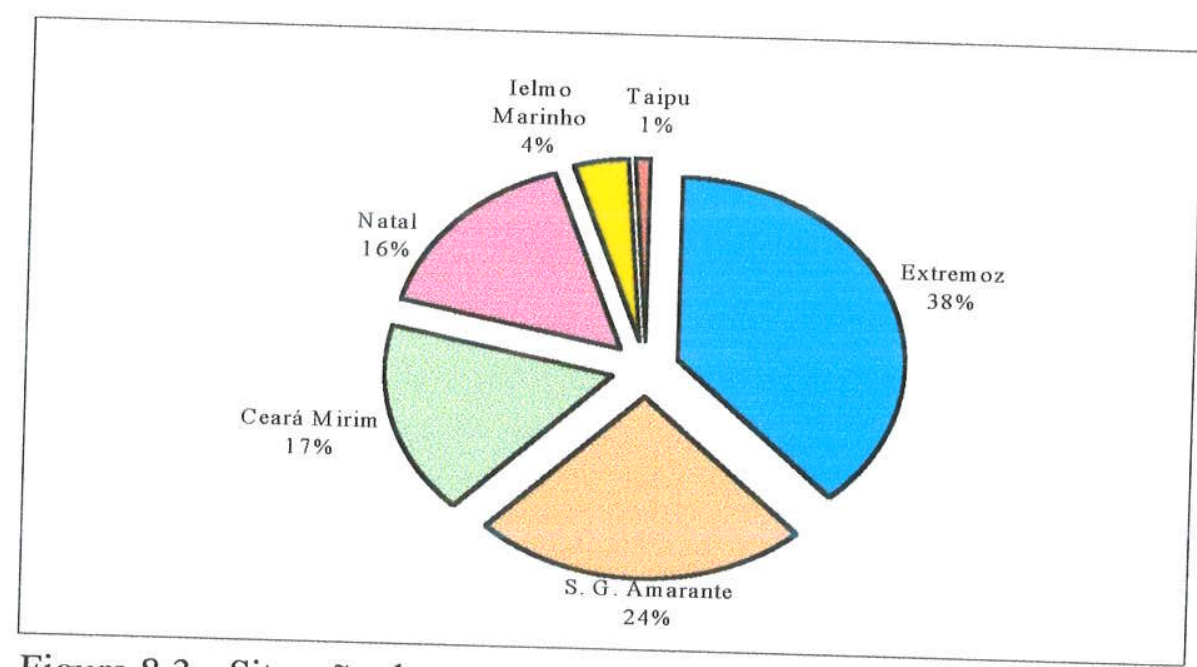

Figura 8.3 - Situação dos poços cadastrados nos municípios inseridos Fonte: (CASTRO, 2000)

No médio curso, onde as características hidrogeológicas são diferentes, por se constituírem de maiores espessuras sedimentares e por haverem trechos dos rios perenizados, o número de poços tubulares é superior aos cacimbões. Consequentemente as obras de captação apresentam maiores variações nas suas profundidades, dependendo dos locais onde foram construídos, de modo que estas variações oscilam entre 8 a 30 metros nos cacimbões e de 30 a 130 metros nos poços tubulares, com usos destinados ao consumo humano e atividades agrícolas. As vazões explotadas neste setor comprendem a faixa de 3,0 a $20 \mathrm{~m}^{3} / \mathrm{h}$. 


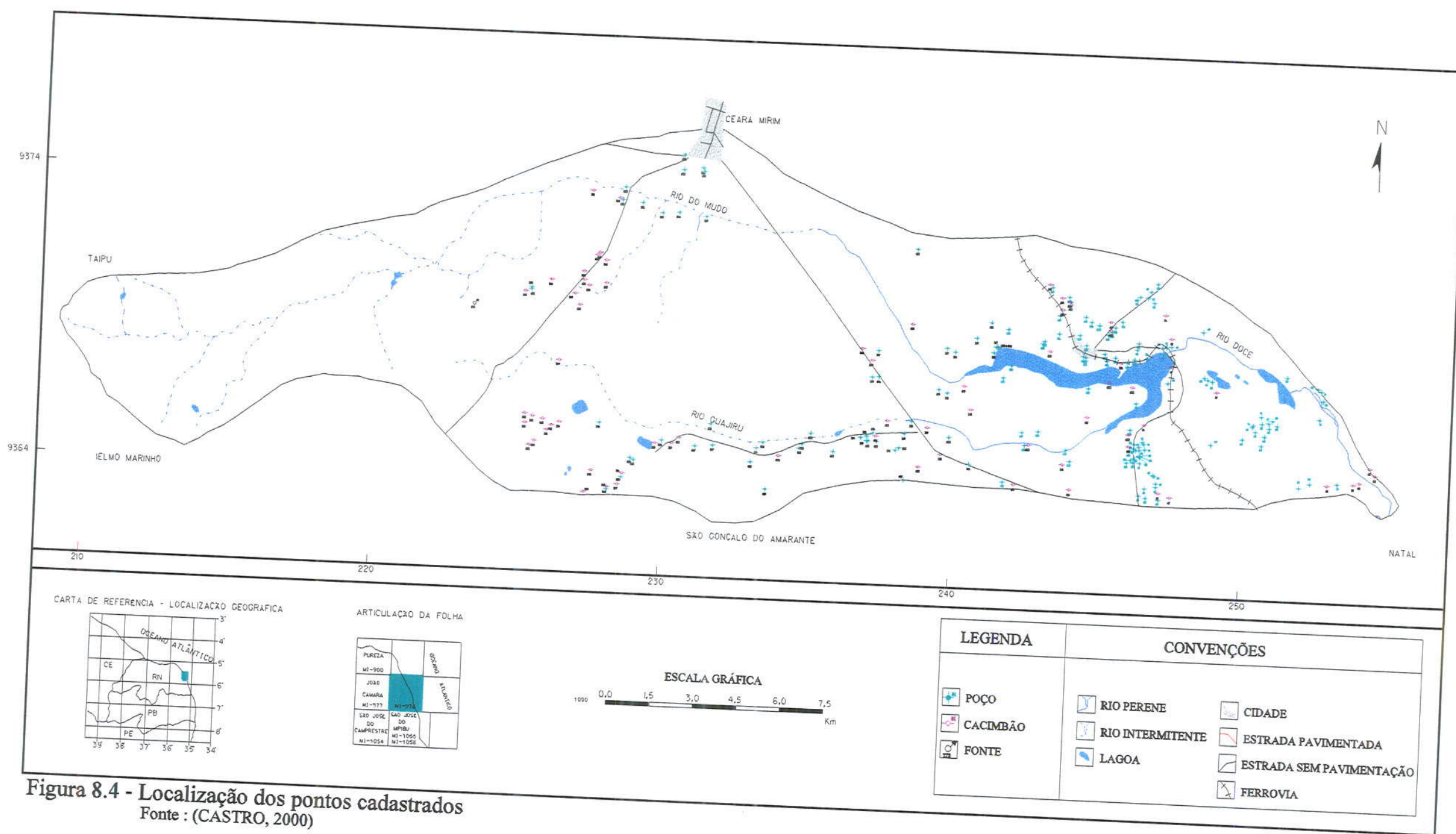


No baixo curso da bacia, devido a existência dos corpos de águas superficiais (rios e lagoas) e do expressivo potencial do Sistema Aqüífero Dunas/Barreiras os projetos das obras de captação e dos usos de água são mais diversificados. Nas proximidades dos rios e lagoas normalmente são construidos cacimbões, com profundidades de 1,0 a 8 metros, exceto quando se trata de hotéis, áreas de lazer, ou projetos de irrigação. Nestes casos os poços tubulares apresentam profundidades de até 70 metros com média de 50 metros. As vazões explotadas no curso inferior da bacia variam de $5,0 \mathrm{~m}^{3} / \mathrm{h}$ nas granjas e balneários a $120 \mathrm{~m}^{3 / h}$ nas áreas industriais.

De um modo geral os poços tubulares são perfurados com diâmetros de 10 ou 14 polegadas e diâmetro de revestimento que varia de 4,0 a 8,0 polegadas. A altura média da boca em relação a cota do terreno é de 0,50 metro. Normalmente são revestidos com tubos geomecânicos e em alguns casos com ferro galvanizado. Os filtros são do tipo geomecânico ou inoxidáveis e apresentam pré-filtro. As figuras 8.5 a 8.8 , representam os perfis construtivos e litológicos dos poços das unidades industriais e dos sistemas de abastecimento
público.

\section{$8.2-U s o s$}

O cadastro dos poços e usuários de água indicou, basicamente a existência de três usos: humano, industrial e irrigação. A lagoa de Extremoz é usada principalmente para o abastecimento público e atende parte do consumo da indústria COTENE localizada fora do domínio da bacia do rio Doce. Quanto ao uso dos poços tubulares e cacimbões, constatou-se que $76 \%$ são utilizados restritamente para uso humano, $15 \%$ para o uso industrial e $9 \%$ para irrigação, como pode ser visualizado na figura 8.9.

No que se refere ao perfil dos usuários dos poços tubulares atualmente ativados, (total de 171), 60\% são de particulares, $24 \%$ são gerenciados pelos serviços de abastecimento público (SAAE e CAERN) e 16\% pelas indústrias, (figura 8.10).

\subsection{1 - Abastecimento Público}

Dos seis municípios inseridos na bacia do rio Doce, dois entre estes têm seu sistema de abastecimento público de água efetuado através das bacias vizinhas, é o caso das cidades de Ielmo Marinho, que é abastecida através de poços tubulares localizados nos aluviões do rio Potengi, Bacia Potengi, e a cidade de Taipu cujo abastecimento é realizado através do sistema integrado da fonte de Pureza, na bacia de Maxaranguape 


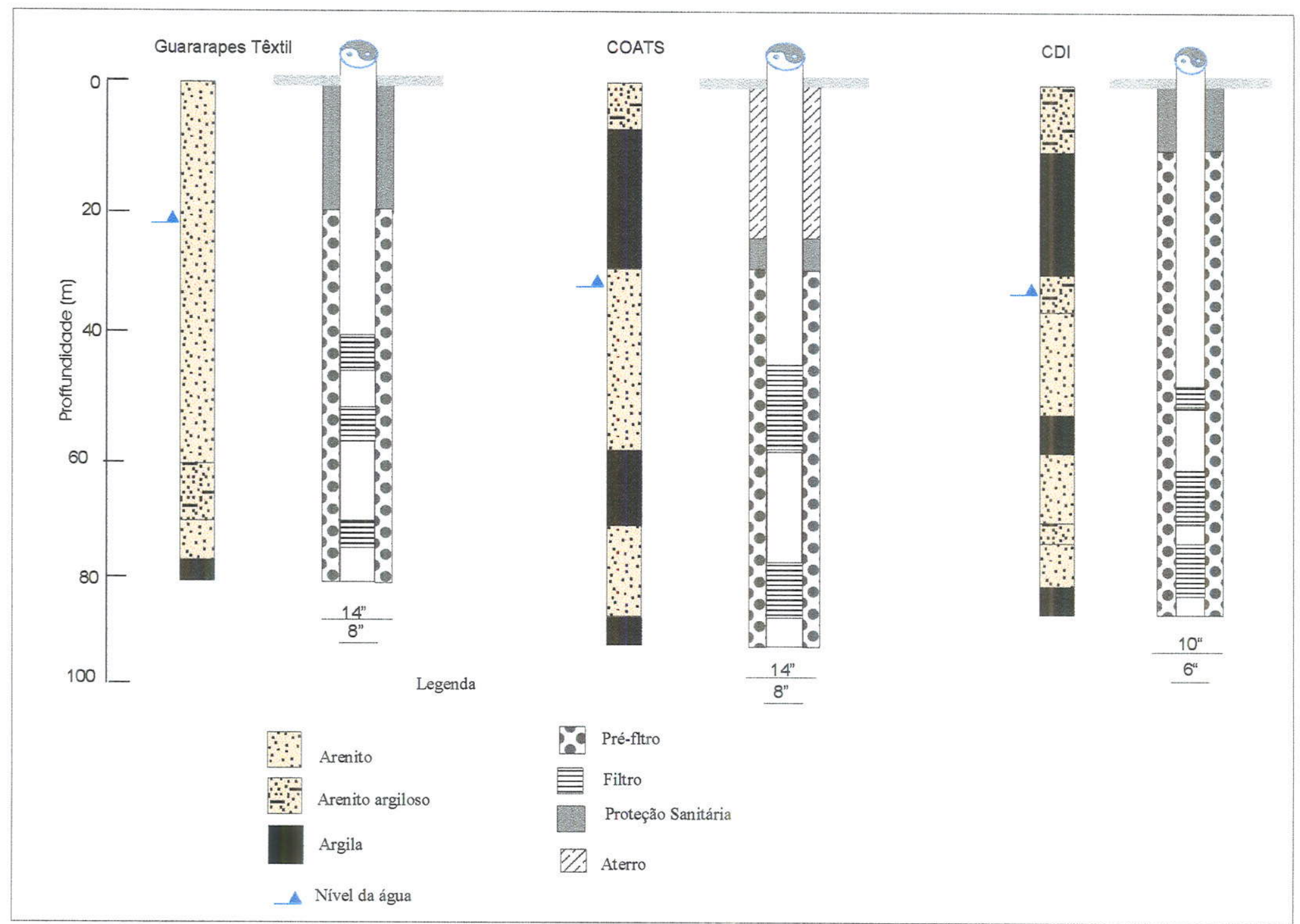

Figura 8.5 - Colunas construtivas e litológicas dos poços tubulares localizados nas unidades industriais Fonte:(CASTRO, 2000) 


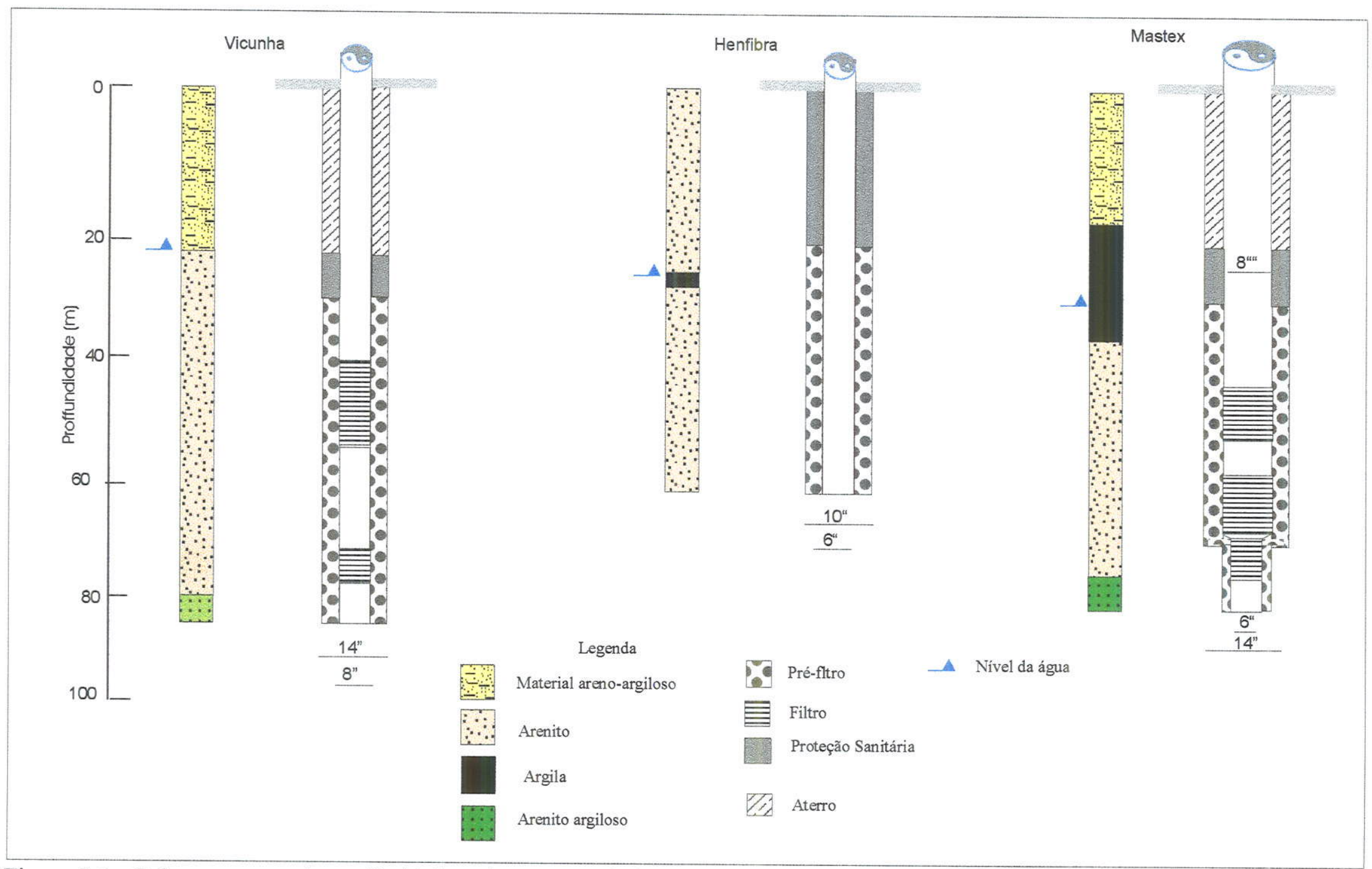

Figura 8.6 - Colunas construtivas e litológicas dos poços tubulares localizados nas unidades industriais Fonte: (CASTRO, 2000) 


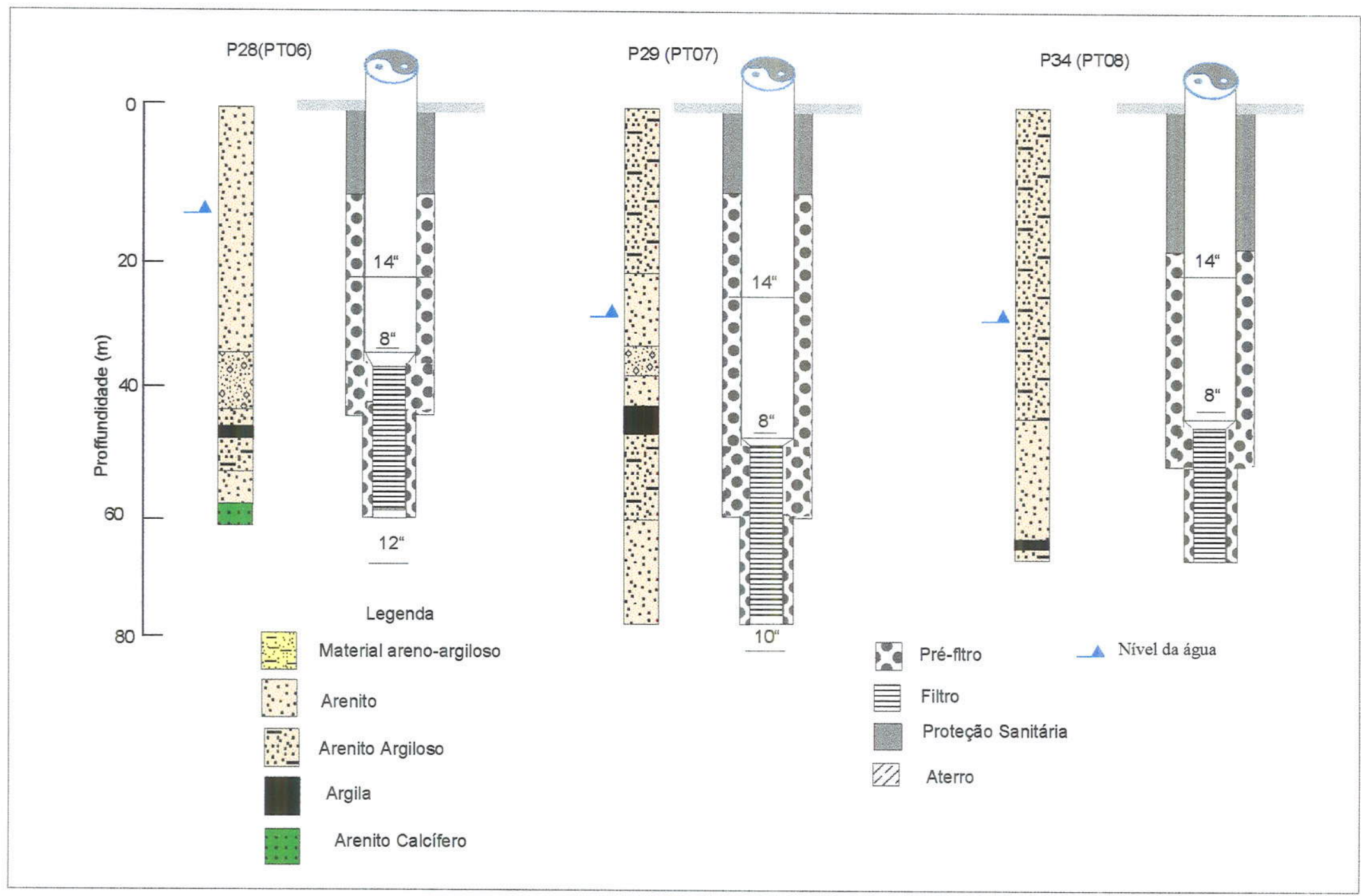

Figura 8.7 - Colunas construtivas e litológicos dos poços tubulares do abastecimento público da Zona Norte de Natal administrados pela Companhia de Água e Esgoto do RN-(CAERN)

Fonte:( CASTRO, 2000) 


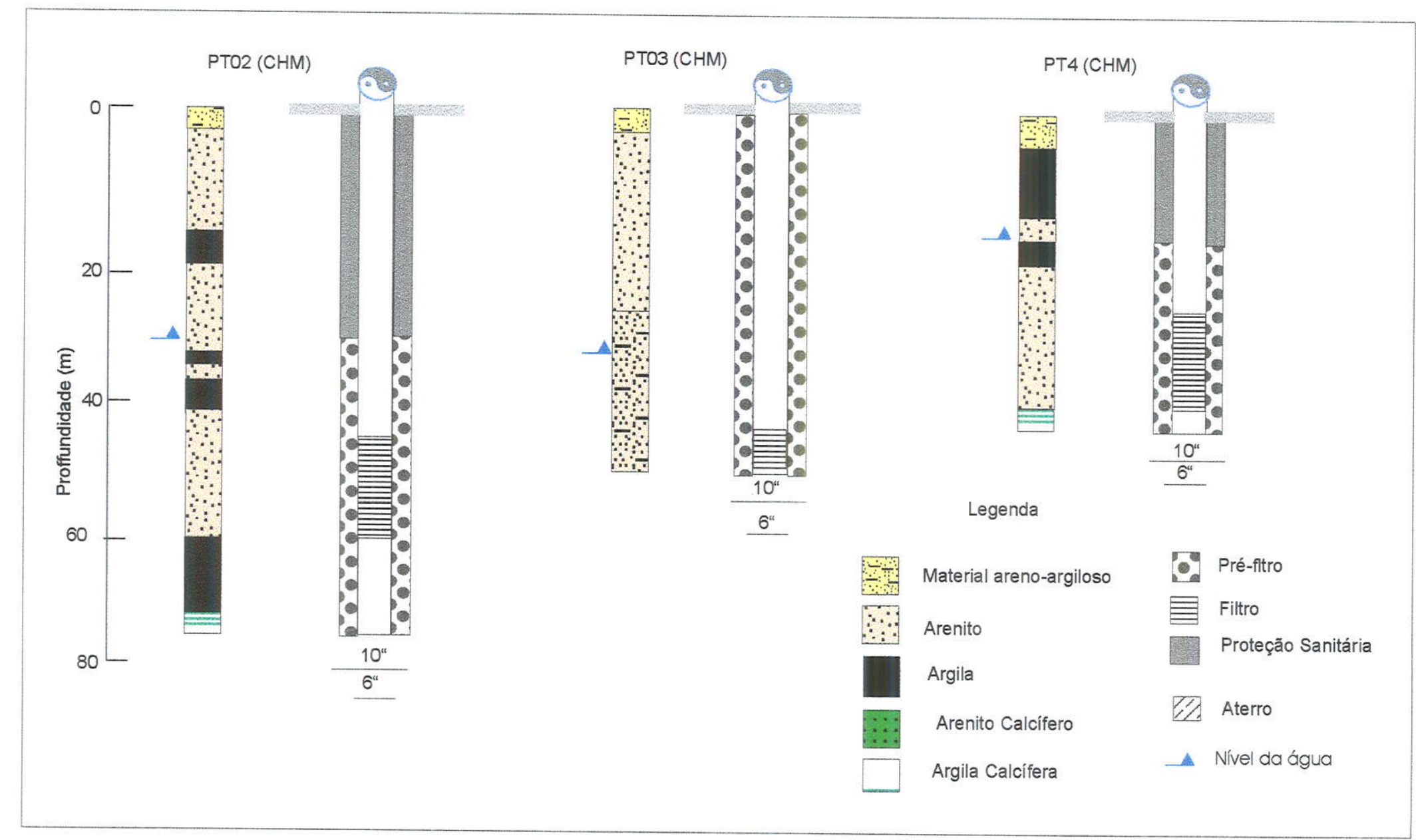

Figura 8.8 - Colunas construtivas e litológicas dos poços tubulares do abastecimento público da cidade de Extremoz administrados pelo Serviço Autônomo de Águas e Esgotos (SAAE)

Fonte:( CASTRO, 2000) 


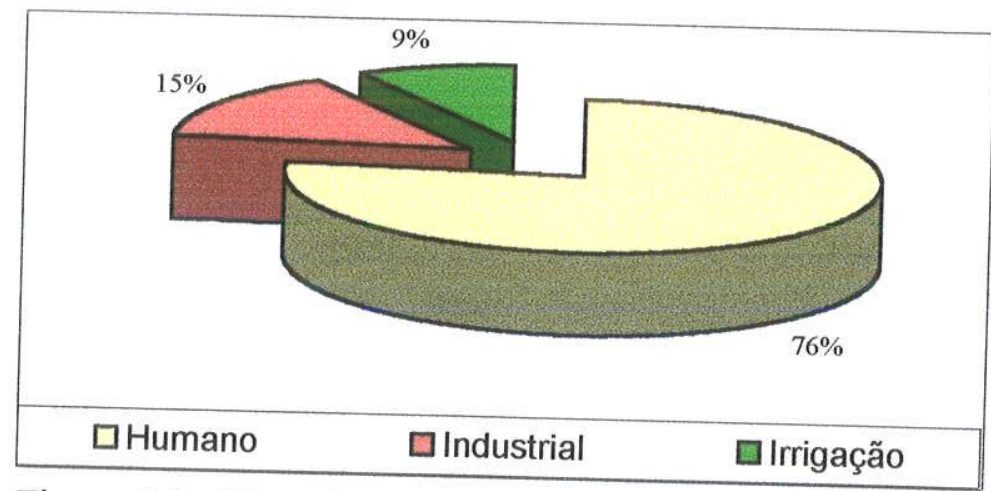

Figura 8.9 - Usos dos poços tubulares e cacimbões na bacia do rio Doce.

Fonte: (CASTRO, 2000).

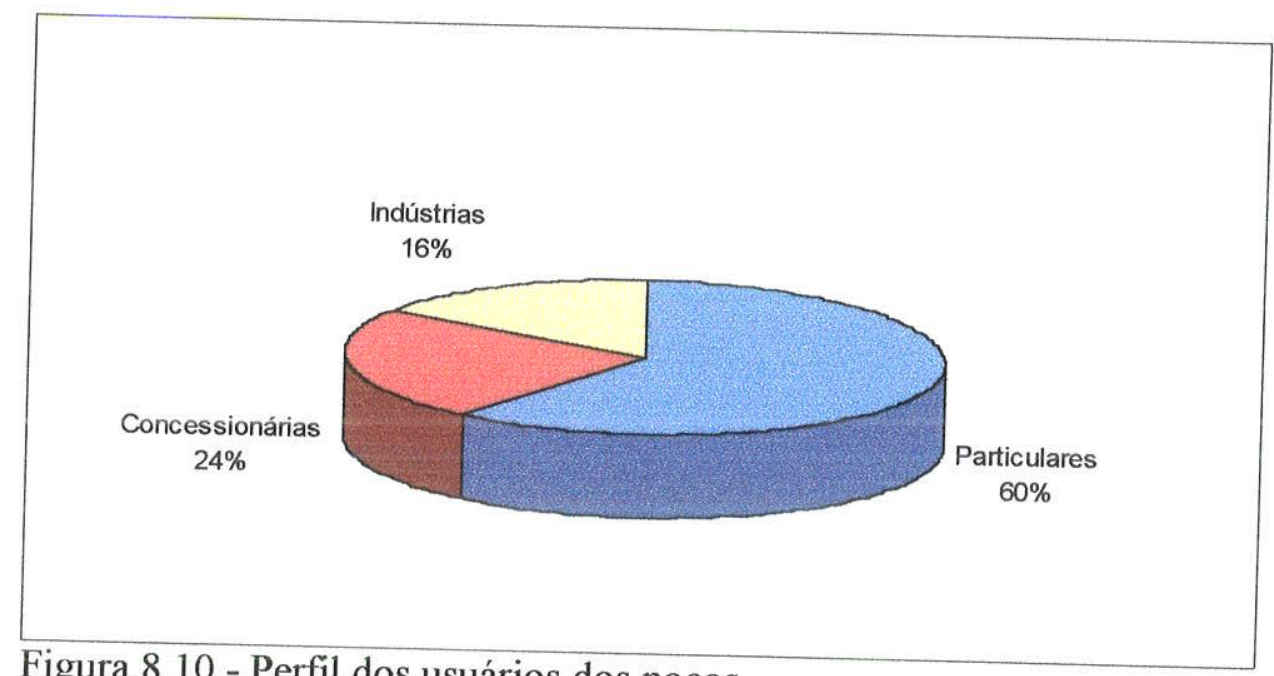

Figura 8.10 - Perfil dos usuários dos poços

Fonte: (CASTRO, 2000)

Na bacia do Rio Doce as demandas concentram-se principalmente no seu curso inferior, devido à existência da lagoa e do expressivo potencial do sistema aqüífero Dunas/Barreiras. Consequentemente houve um maior desenvolvimento econômico caracterizado pelo distrito industrial e uma acentuada expansão urbana representada por parte da zona norte da cidade de Natal, Extremoz e São Gonçalo do Amarante.

No caso da Zona Norte de Natal o seu abastecimento é gerenciado pela Companhia de Águas e Esgotos do Estado do Rio Grande do Norte (CAERN ), que utiliza duas fontes de captação: as águas da lagoa de Extremoz e as águas subterrâneas do sistema aqüífero Dunas/Barreiras. De forma que a captação da lagoa de Extremoz, caracteriza-se como uma transposição de águas, pois os bairros beneficiados localizam-se na Bacia Potengi. 
Nos últimos vinte anos, a zona norte tem sido área preferencial dos programas habitacionais do governo e paralelamente a estes programas a CAERN desenvolveu um projeto de captação na lagoa de Extremoz com capacidade para $1000 \mathrm{l} / \mathrm{s}$ a implantar-se em duas etapas, com o objetivo de abastecer a zona Norte. Segundo informações da CAERN, o volume captado atual é de $634 \mathrm{l} / \mathrm{s}$. Quanto ao abastecimento da zona norte através do sistema aqüífero Dunas/Barreiras, cujos poços tubulares estão localizados na bacia do rio Doce, compreende atualmente um volume da ordem de $8,3 \times 10^{6} \mathrm{~m}^{3} /$ ano

A população urbana de Extremoz e parte da população rural dos municípios de Extremoz, São Gonçalo do Amarante e Ceará Mirim têm seu abastecimento realizado através de poços tubulares localizados na bacia do rio Doce que são gerenciados pelo Serviço Autônomo de Águas e Esgotos, (SAAE). Para a sede municipal de Ceará Mirim o abastecimento público de água é realizado através de um sistema de adução, cujo ponto de captação é na lagoa de Extremoz, através de uma bateria de sete poços tubulares que explota anualmente um volume de $2,4 \times 10^{6} \mathrm{~m}^{3}$. Atualmente todo o sistema SAAE capta 4,0 $\times 10^{6}$ $\mathrm{m}^{3} / \mathrm{ano}$, atendendo parte dos municípios de Extremoz, Ceará Mirim e São Gonçalo do Amarante.

Portanto, a soma dos volumes explotados pelo $\operatorname{SAAE}\left(4,0 \times 10^{6} \mathrm{~m}^{3} / \mathrm{ano}\right)$, pela CAERN $\left(8,3 \times 10^{6} \mathrm{~m}^{3} /\right.$ ano $)$, e pelos particulares $\left(2,3 \times 10^{6} \mathrm{~m}^{3} / \mathrm{ano}\right)$, atinge atualmente um consumo de água subterrânea, para o abastecimento público, da ordem de $14,6 \times 10^{6} \mathrm{~m}^{3} / \mathrm{ano}$. Este valor adicionado ao volume anual captado da lagoa de Extremoz, que é de $20 \times 10^{6} \mathrm{~m}^{3}$ constitui uma cifra estimada em $34,6 \times 10^{6} \mathrm{~m}^{3} / \mathrm{ano}$, destinada ao uso humano.

\subsection{2 - Usos Industrial e Agrícola}

Quanto ao uso industrial, é utilizado atualmente um volume de $1,6 \times 10^{6} \mathrm{~m}^{3} / \mathrm{ano}$ da lagoa de Extremoz e $5,7 \times 10^{6} \mathrm{~m}^{3} / a n o$ das águas subterrâneas do sistema aqüifero Dunas/Barreiras, totalizando $7,3 \times 10^{6} \mathrm{~m}^{3} /$ ano. Nas atividades agrícolas são utilizados 1,0 $\times 10^{6} \mathrm{~m}^{3} /$ ano de água subterrânea.

A figura 8.11 mostra uma ilustração esquemática dos diversos usos dos recursos hidricos na bacia estudada. Foi elaborada com base no cadastro de poços tubulares, cacimbãos, usuários dos recursos hidricos e no mapa de uso e ocupação do solo. 


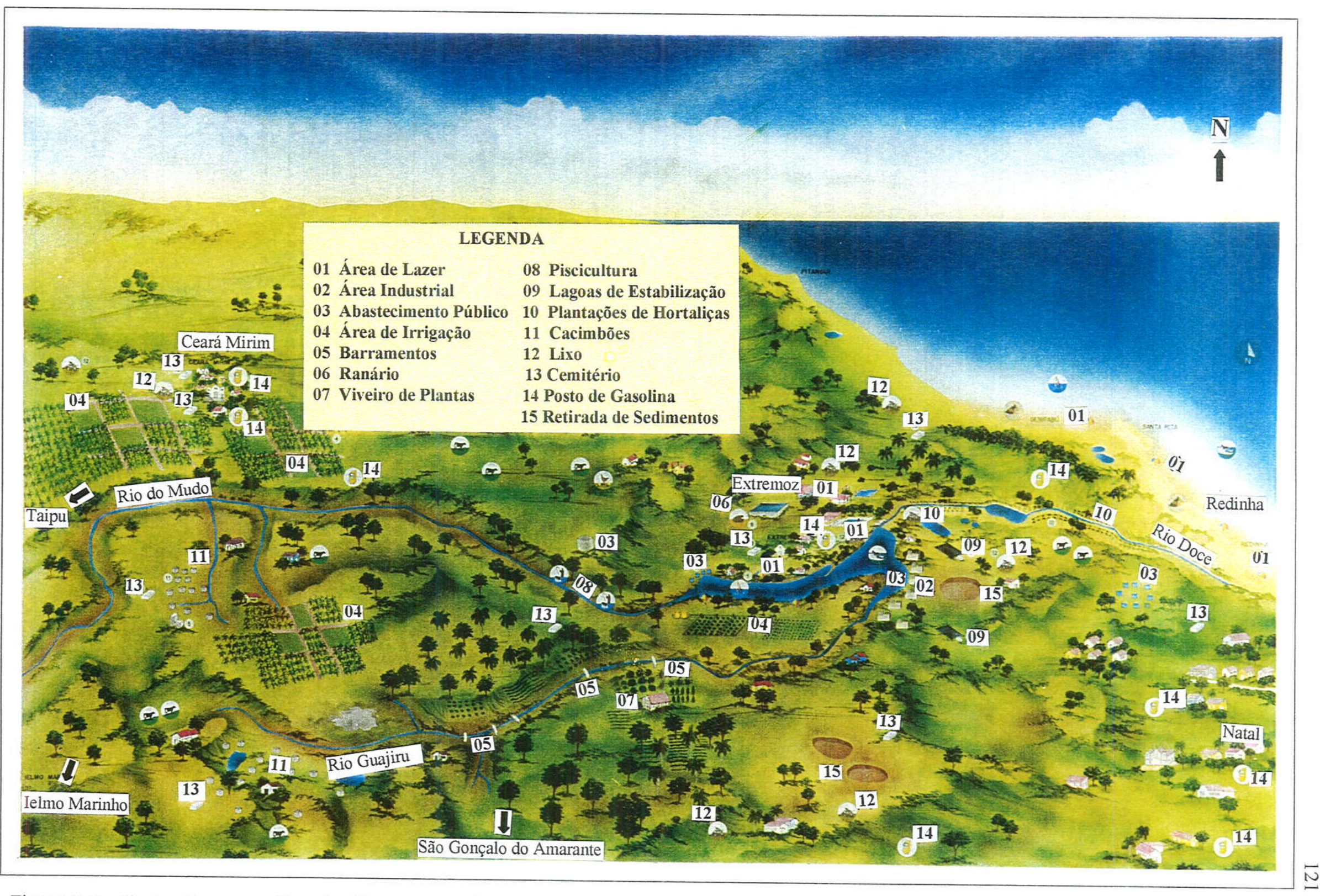

Figura 8.11 - Ilustração esquemática dos diversos usos dos recursos hídricos e alguns usos do solo na bacia do rio Doce Fonte: (CASTRO, 2000) 


\section{3 - Demandas Consumo Real e Ofertas}

A demanda total de água de uma determinada região compreende os usos públicos, industrial, atividades agropecuárias e recreativas. Os usos públicos da água se referem àquelas demandas que são supridas por sistemas de abastecimento de água. Estes sistemas são dimensionados para atender às demandas que dependem diretamente da população a ser atendida. A cota per capita, em litro por habitante por dia abrange o consumo destinado a esses usos os quais são em função dos costumes e grau de desenvolvimento da população.

A projeção demográfica determina a estimativa da demanda e neste estudo a demanda urbana foi estimada com base na projeção demográfica, da zona norte, caracterizada por SANTOS (1999) e na população urbana da cidade de Extremoz, projetada para os anos 2000,2005 e 2010, em que foi aplicada uma taxa de crescimento de 4,44\% ao ano, IDEMA (1999), tendo como base a contagem populacional de 1996. A projeção da população rural foi estimada na média das taxas de crescimento dos municípios de Extremoz, São Gonçalo do Amarante e Ceará Mirim, indicou um valor médio de 3,25\% ao ano, tendo como base a contagem populacional de 1996, IDEMA (1999). Considerando as projeções populacionais estimadas e admitindo um fator de consumo "per capita" de 200 1/hab.dia, para a população urbana e 1001/hab.dia para a população rural, foi estimada uma demanda total (urbana e rural) de $23,6 \times 10^{6} \mathrm{~m}^{3} /$ ano para o ano $2000,28,9 \times 10^{6} \mathrm{~m}^{3} /$ ano para o ano $2005 \mathrm{e} 35,8 \times 10^{6} \mathrm{~m}^{3} /$ ano para o ano 2010 (tabela 8.1). No entanto, ao comparar as demandas calculadas para o ano 2000 com o consumo real verificou-se um índice de desperdício de $46,6 \%$ no abastecimento urbano e rural da bacia do rio Doce e de $21 \%$ no abastecimento da zona norte de Natal, (tabela $8.2)$

Na estimativa da demanda industrial foi considerada uma área útil atual de 400 ha e áreas de 576 ha e 752 ha para os anos de 2005 e 2010 respectivamente, sendo a última (752 ha) a mesma considerada para projeto de abastecimento da CAERN, (SANTOS, 1999). Com base nos tipos de indústrias existentes e naquelas que possivelmente se instalarão nos próximos dez anos no distrito industrial, (alimentícias, bebidas e têxtil), foi estimada uma vazão média diária de $0,40 \mathrm{l} / \mathrm{s}$.ha, $\left(12.614 \mathrm{~m}^{3} /\right.$ ha. ano), que resultou em uma demanda de $5,0 \mathrm{x}$ $10^{6} \mathrm{~m}^{3} /$ ano para o ano $2000,7,3 \times 10^{6} \mathrm{~m}^{3} /$ ano para o ano 2005 e $9,4 \times 10^{6} \mathrm{~m}^{3} /$ ano para o ano de 2010, (tabela 8.1). Comparando-se a demanda industrial calculada para o ano 2000 e o consumo real neste mesmo ano, constatou-se um desperdício em tomo de $31,5 \%$, (tabela 8.2 ). 
Tabela 8.1 - Projeção das populações e demandas calculadas para os anos 2000, 2005 e 2010

\begin{tabular}{|c|c|c|c|c|c|c|c|c|}
\hline \multicolumn{4}{|c|}{ PROJEÇÃO DAS POPULACÕES } & \multicolumn{5}{|c|}{ DEMANDAS CALCULADAS } \\
\hline \multirow{2}{*}{$\begin{array}{c}\text { População } \\
\text { Urbana e Rurall Áreas de } \\
\text { projetos agrícolas e } \\
\text { Irrigacãa } \\
\end{array}$} & \multicolumn{3}{|c|}{ ANO } & \multirow{2}{*}{$\begin{array}{l}\text { Demandas } \\
\qquad\left(\mathrm{m}^{3} / \mathrm{h}\right)\end{array}$} & \multicolumn{4}{|c|}{ ANO } \\
\hline & 2000 & 2005 & 2010 & & Consumo & 2000 & 2005 & 2010 \\
\hline $\begin{array}{l}\text { População Urbana da } \\
\text { Bacia do Rio Doce (BRD) }\end{array}$ & 96.969 & 120.494 & 149.727 & $\begin{array}{c}\text { Demanda Urbana (DURB) } \\
\text { BRD }\left(\mathrm{m}^{3} / \mathrm{ano}\right)\end{array}$ & 200L/hab.dia & $7,0 \times 10^{6}$ & $8,7 \times 10^{6}$ & $10,9 \times 10^{6}$ \\
\hline $\begin{array}{l}\text { População Rural } \\
\text { da BRD }\end{array}$ & 21.536 & 25.268 & 29.647 & $\begin{array}{c}\text { Demanda Rural (DRUR) } \\
\text { BRD (mªno) }\end{array}$ & 100L/hab.dia & 786.064 & 922.282 & $1,1 \times 10^{6}$ \\
\hline População Total da BRD & 118.505 & 145.762 & 179.374 & \multicolumn{2}{|c|}{$\begin{array}{c}\text { Demanda Total } \\
\text { (DURB + DRUR) da BRD }\end{array}$} & $7,8 \times 10^{6}$ & $9,6 \times 10^{6}$ & $12,0 \times 10^{6}$ \\
\hline $\begin{array}{l}\text { População da Zona } \\
\text { Norte abastecida com } \\
\text { Águas da BRD }\end{array}$ & 216.360 & 265.552 & 325.916 & $\begin{array}{l}\text { Demanda Urbana } \\
\text { Zona Norte }\left(\mathrm{m}^{3} / \mathrm{ano}\right)\end{array}$ & $\begin{array}{c}\text { 200L/hab.dia } \\
\text { Total } \\
\text { (A bustecimento humano) }\end{array}$ & $\begin{array}{l}15,8 \times 10^{6} \\
23,6 \times 10^{6} \\
\end{array}$ & $19,3 \times 10^{6}$ & $\begin{array}{l}23,8 \times 10^{6} \\
35,8 \times 10^{6}\end{array}$ \\
\hline $\begin{array}{l}\text { Area irrigável } \\
\text { (ha) }\end{array}$ & 60 & 60 & 60 & $\begin{array}{r}\text { Demanda Agrícola } \\
\left(\mathrm{m}^{3} / \mathrm{ano}\right)\end{array}$ & $10.000 \mathrm{~m}^{3} / \mathrm{ha}$.ano & 600.000 & 600.000 & 600.000 \\
\hline $\begin{array}{l}\text { Area de projeto para } \\
\text { Empreendimento Industrial } \\
\text { (ha) }\end{array}$ & 400 & 576 & 752 & $\begin{array}{l}\text { Demanda Industrial } \\
\qquad\left(\mathrm{m}^{3} / \mathrm{ano}\right)\end{array}$ & $12.614 \mathrm{~m}^{3} /$ ha.ano & $5,0 \times 10^{6}$ & $7,3 \times 10^{6}$ & $9,4 \times 10^{6}$ \\
\hline Deman & ida Total & Abastec & $\begin{array}{l}\text { ento Hun } \\
\left(\mathrm{m}^{3} / \mathrm{ano}\right)\end{array}$ & nano + Irrigaçẵo+ Indústri: & & $29,2 \times 10^{6}$ & $36,8 \times 10^{6}$ & $45,8 \times 10^{6}$ \\
\hline
\end{tabular}

\section{Legenda:}

$\mathrm{BRD}=$ Bacia do Rio Doce

DURB $=$ Demanda Urbana

DRUR $=$ Demanda Rural 
Tabela 8.2 - Comparação entre os valores estimados das demandas calculadas e consumo real no ano 2000 , e demandas estimadas para o ano 2010, incluindo os índices de desperdícios

\begin{tabular}{|c|c|c|c|c|c|c|}
\hline 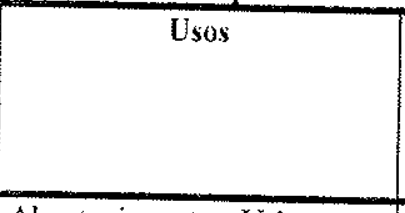 & $\begin{array}{c}\text { Demandas Calculadas } \\
\text { Ano 2000 } \\
\left(\mathrm{m}^{3} / \mathrm{ano}\right)\end{array}$ & $\begin{array}{l}\text { Consumo Real } \\
\text { Ano 2000 } \\
\left(\mathrm{m}^{3} / \mathrm{ano}\right)\end{array}$ & $\begin{array}{l}\text { Situaçāo de } \\
\text { Desperdício }\end{array}$ & $\begin{array}{l}\text { Demandas } \\
\text { Calculadas } \\
\text { Ano (2010) } \\
\left(\mathrm{m}^{3} / \mathrm{ano}\right)\end{array}$ & $\begin{array}{l}\text { Demandas Estimadas } \\
\text { Para oAno } 2010 \\
\text { Incluindo desperdicios } \\
\quad\left(\mathrm{m}^{3} / \mathrm{ano}\right)\end{array}$ & $\begin{array}{c}\text { Incremento entre Consumo } \\
\text { Real (Ano 2000) e } \\
\text { Demandas Estimadas (Ano } \\
2010) \text { com } \\
\text { desperdícios }\left(\mathrm{m}^{3} / \mathrm{ano}\right) \\
\end{array}$ \\
\hline $\begin{array}{l}\text { Abastecimento Urbano e } \\
\text { Rural da Bacia do Rio } \\
\text { Doce (BRD) }\end{array}$ & $\begin{array}{l}7,8 \times 10^{6} \\
\text { (Água Subterrânea) }\end{array}$ & $\begin{array}{l}14,6 \times 10^{6} \\
\text { (Agua Subtersânea) }\end{array}$ & $46,5 \%$ & $12,0 \times 10^{6}$ & $\begin{array}{l}17,6 \times 10^{6} \\
\text { (Água Subterrânea) }\end{array}$ & $3,0 \times 10^{6}$ \\
\hline $\begin{array}{l}\text { Abastecimento da Zona } \\
\text { Norte pelas águas da BRD } \\
\text { (lagoa de Extremoz) }\end{array}$ & $\begin{array}{l}15,8 \times 10^{6} \\
\text { (Agua Superficial) }\end{array}$ & $\begin{array}{l}20,0 \times 10^{6} \\
\text { (Agua Superficial) }\end{array}$ & $21 \%$ & $23,8 \times 10^{6}$ & $\begin{array}{l}28,8 \\
\text { Água Superficial) }\end{array}$ & $8,8 \times 10^{6}$ \\
\hline Uso Agrícola & $\begin{array}{l}600.000 \\
\text { (Água Subterrânea) }\end{array}$ & $\begin{array}{l}\text { Consumo Agrícola } \\
1,0 \times 10^{6} \\
(\text { Agua Subterrânea) } \\
\end{array}$ & $40 \%$ & 600.000 & $\begin{array}{l}1,0 \times 10^{6} \\
\text { (Água Subterrânea) }\end{array}$ & 0,0 \\
\hline Uso Industrial & $\begin{array}{l}5,0 \times 10^{6} \\
\text { Agua Subtertãnea }+ \text { Agua } \\
\text { Superficial) }\end{array}$ & $\begin{array}{l}\text { Consumo Industrial } \\
7,3 \times 10^{5} \\
\text { Água Superf. }\left(1,6 \times 10^{6}\right) \\
\text { Água Subter. }\left(5,7 \times 10^{6}\right) \\
\end{array}$ & $31,5 \%$ & $9,4 \times 10^{6}$ & $\begin{array}{l}12,0 \times 10^{6} \\
\text { Agua Superf. }\left(1,6 \times 10^{6}\right) \\
\text { Agua Subter. }\left(10,4 \times 10^{6}\right)\end{array}$ & 4,7 \\
\hline \multicolumn{4}{|c|}{ TOTAL } & $45,8 \times 10^{6}$ & $59,4 \times 10^{6}$ & $16,5 \times 10^{6}$ \\
\hline
\end{tabular}


Para a determinação da demanda agrícola foi aplicado o fator de necessidade de atendimento, de 10.000 ha. ano (TEIXEIRA, 1988). Considerando uma área efetivamente irrigada estimada em 60ha, e não apresentando perspectiva de desenvolvimento quanto às atividades agrícolas na região, até o ano 2010, (SERHID, 1998), a demanda agrícola estimada para os anos de 2000,2005 e 2010 foi avaliada em $600,000 \mathrm{~m}^{3} / \mathrm{ano}$. O consumo real no ano 2000 , indicou uma cifra de $1,0 \times 10^{6} \mathrm{~m}^{3} / \mathrm{ano}$, caracterizando um desperdício da ordem de $40 \%$, (tabela 8.2).

Atualmente, o consumo real total, incluindo todas as demandas da bacia, atinge cerca de $42,9 \times 10^{6} \mathrm{~m}^{3} / \mathrm{ano}$, sendo que, deste total, $21,3 \times 10^{6} \mathrm{~m}^{3} / \mathrm{ano}(49,6 \%$ do consumo total), é de água subterrânea, equivalente a $28 \%$ das reservas reguladoras do sistema aqüífero Dunas/Barreiras, avaliadas em $76 \times 10^{6} \mathrm{~m}^{3} /$ ano (capítulo 4, Item 4.3.2), (figura 8.12). Dentro destas expectativas tem-se um volume disponível de $55 \times 10^{6} \mathrm{~m}^{3} / \mathrm{ano}$.

A demanda total estimada para o ano 2010, considerando os índices de desperdícios verificados no consumo real do ano 2000 , indicou uma cifra da ordem de $59,4 \mathrm{x}$ $10^{6} \mathrm{~m}^{3} /$ ano.

Diante desta perspectiva a demanda de água subterrânea poderá variar em função da tomada de decisão da CAERN, em relação a exploração ou não da vazão total do projeto de adução da lagoa de Extremoz que é de 10001/s, cujo volume explorado atualmente é de 634 1/s. Desta forma foram consideradas duas situações: uma em que foi contemplada a captação de 10001/s da lagoa de Extremoz para o abastecimento público, tendo sido nesse caso a demanda de água subterrânea, (sistema aqüífero Dunas/Barreiras), estimada em $29 \times 10^{6}$ $\mathrm{m}^{3} / \mathrm{ano}$, equivalente a $38 \%$ das reservas reguladoras, (tabela 8.3 ). Uma segunda situação considerou que o volume a ser captado da lagoa permanecerá o mesmo que está sendo explorado atualmente $(634 \mathrm{l} / \mathrm{s})$. Dessa forma, a demanda estimada de água subterrânea para o ano de 2010 indicou uma cifra de $37,8 \times 10^{6} \mathrm{~m}^{3} /$ ano, correspondente a $49,7 \%$ das reservas reguladoras, tabela 8.3. A figura 8.12 mostra a situação atual, apresentando o consumo real de águas superficiais e subterrâneas na bacia do rio doce. A figura 8.13 mostra o comportamento das demandas estimadas para o ano 2010.

Estudos realizados recentemente por DINIZ FILHO (1999), na bacia do rio Ceará Mirim, ao norte da bacia estudada, constataram uma subexplotação do aqüífero Barreiras naquela região. De forma que as reservas explotáveis do respectivo aqüifero, na bacia Ceará Mirim, foram avaliadas em torno de $81 \times 10^{6} \mathrm{~m}^{3} / \mathrm{ano}$, demonstrando um potencial hídrico muito superior ao consumo total da região, que é da ordem de $9,9 \times 10^{6} \mathrm{~m}^{3} /$ ano, equivalente a $12,2 \%$ das reservas explotáveis. 
Tabela 8.3 - Comportamento da demanda total estimada de águas subterrâneas (Sistema Aqüífero Dunas/Barreiras), para 0 ano 2010

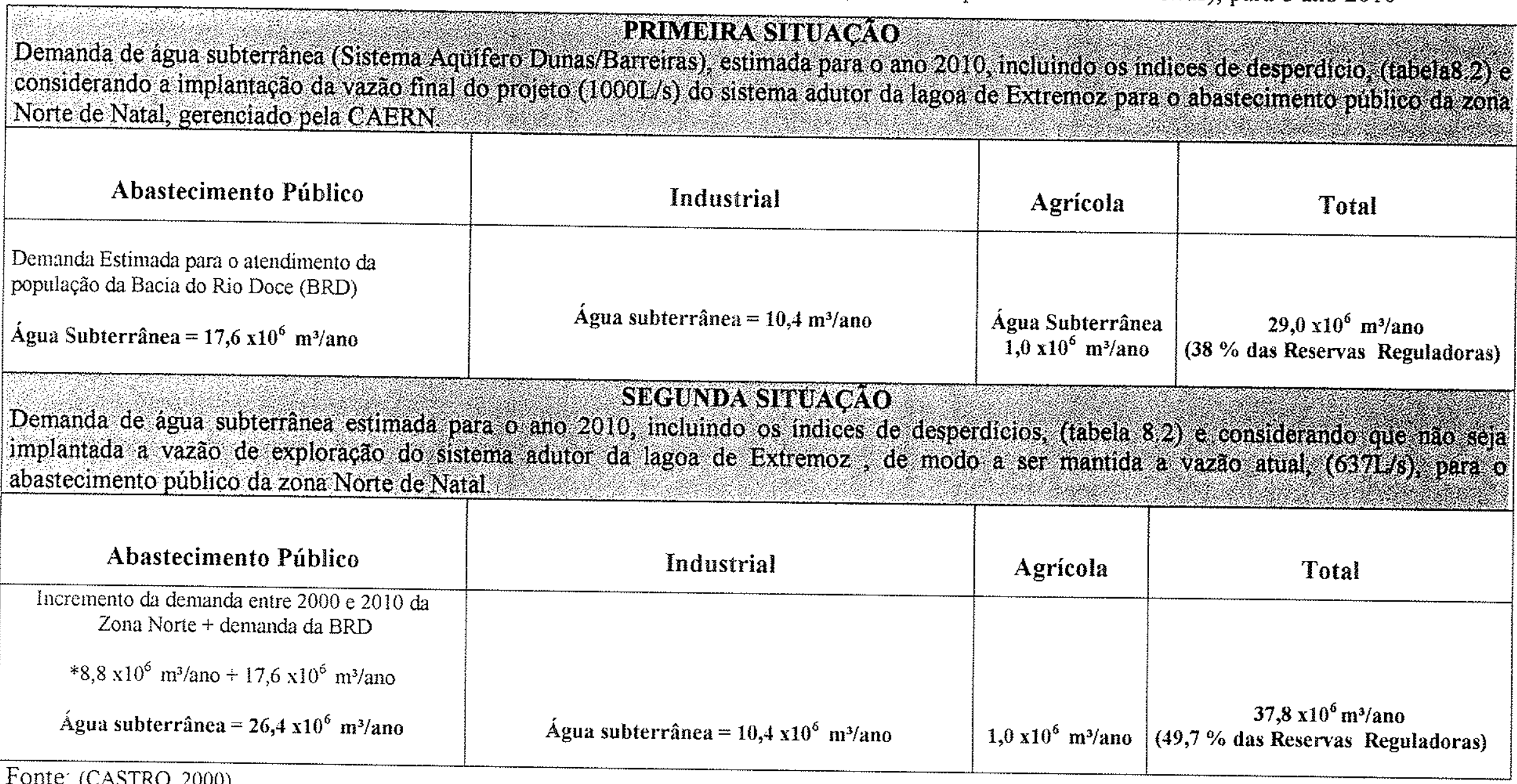

Fonte: (CASTRO, 2000)

*8,8 $\times 10^{6} \mathrm{~m}^{3} / \mathrm{ano}$ - corresponde ao acréscimo no incremento da demanda de água subterrânea para o ano 2010 , caso não seja implantada a vazão final do projeto (1000l/s) do sistema adutor da lagoa de Extremoz para a Zona Norte de Natal.

$B R D=$ Bacia do Rio Doce 


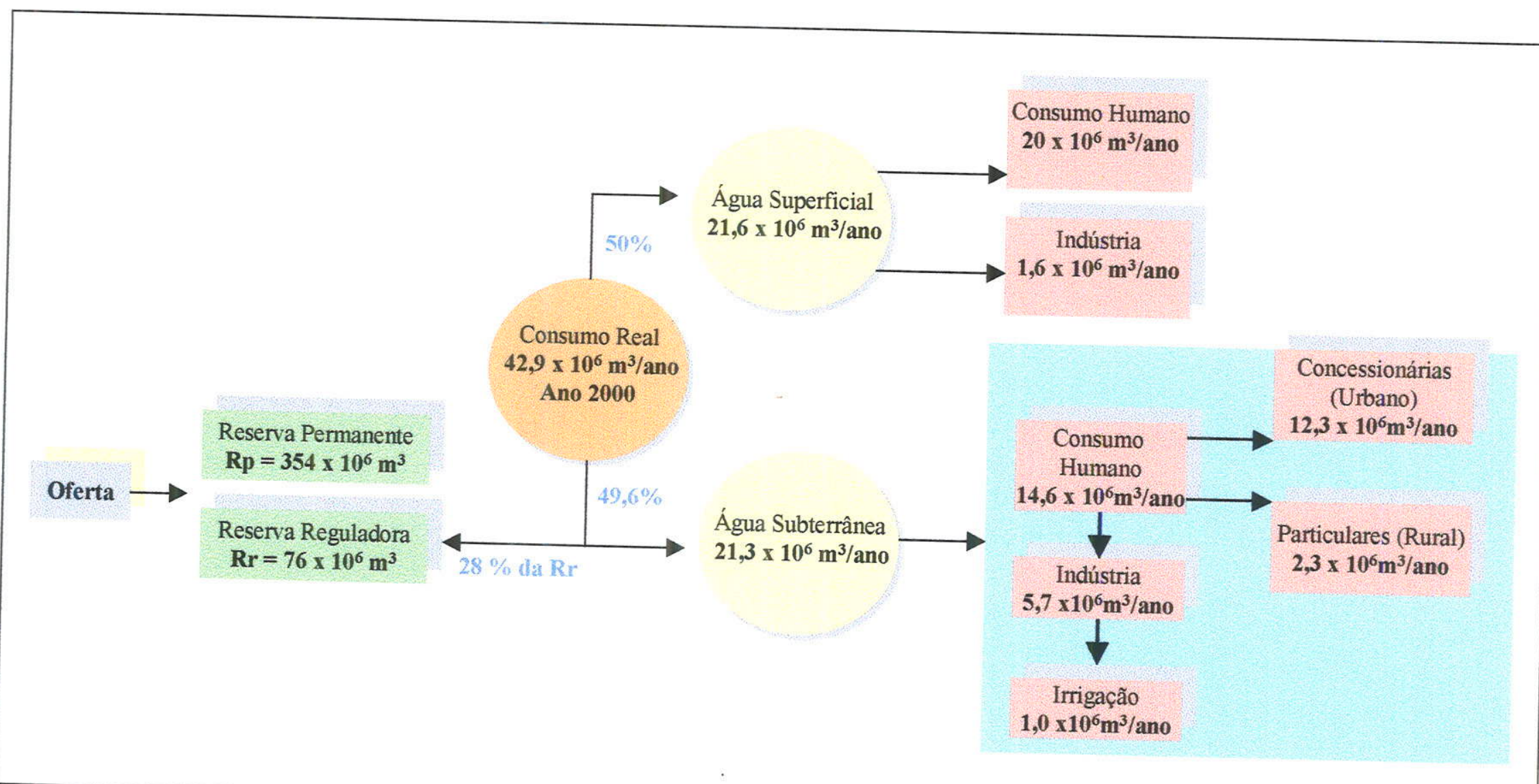

Figura 8.12 - Consumo real de águas superficiais e subterrâneas na Bacia do Rio Doce Fonte: (CASTRO, 2000) 


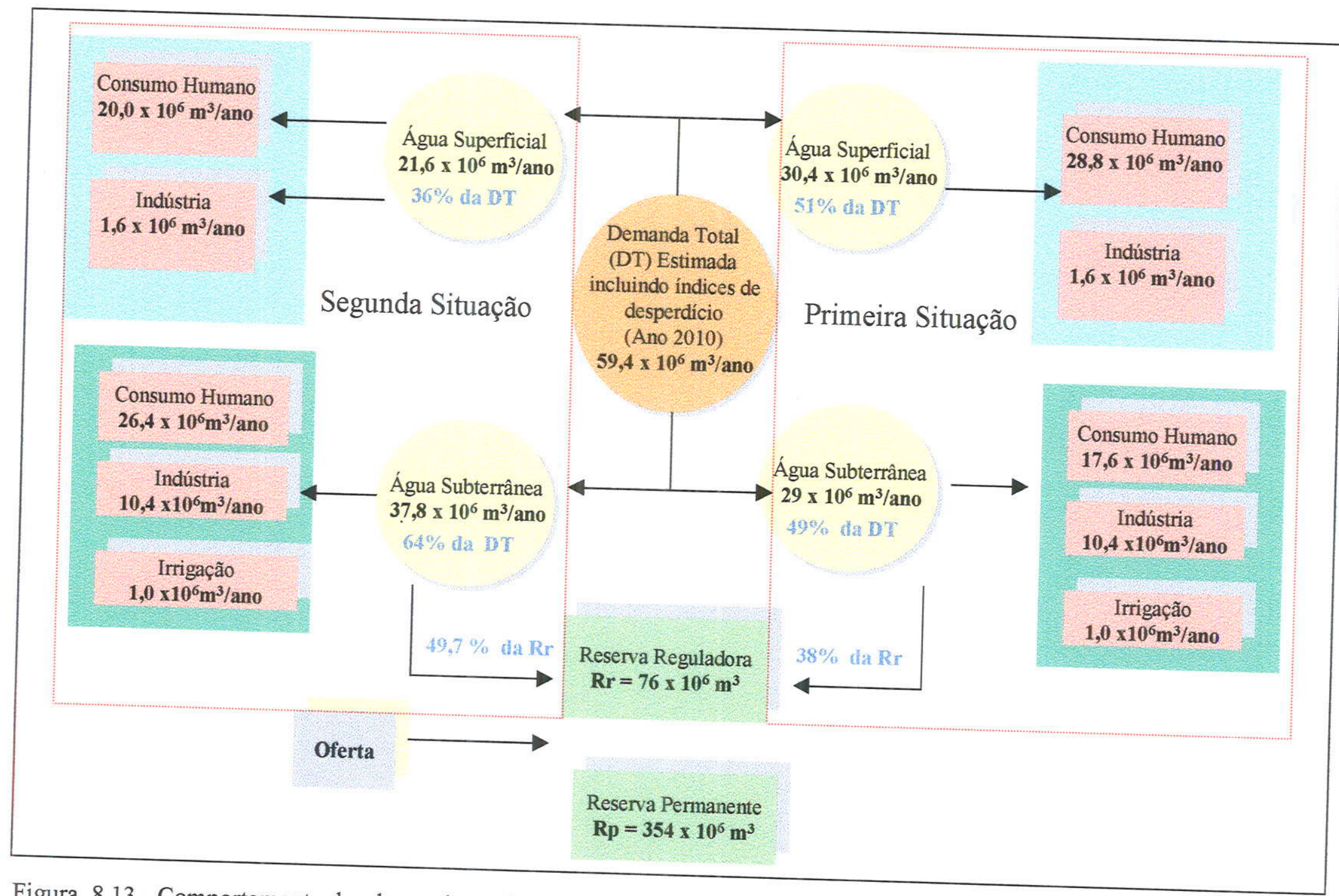
Figura 8.13 - Comportamento das demandas estimadas para o ano de 2010, mostrando a possibilidade de ocorrência de uma
das situações indicadas.

Fonte: (CASTRO, 2000) 
Dentro deste contexto o aqüifero Barreiras na bacia do rio Ceará Mirim tem um volume disponivel de $71 \times 10^{6} \mathrm{~m}^{3} /$ ano. DINIZ FULHO (1999), verificou que essas condições de subexplotação do aqüífero Barreiras são retratadas por encharcamentos quase constantes em grande parte do trecho oriental do vale durante todo o ano, decorrentes de afloramentos do aqüífero freático em fontes e olhos d'água, conseqüência da pouca retirada a que vem sendo submetido o sistema. As avaliações também constataram que os órgãos responsáveis pelo abastecimento têm procurado outras fontes para atendimento da demanda de água para consumo humano na respectiva bacia, sem ter considerado o elevado potencial hidrogeológico do aqüífero Barreiras, cuja utilização mais efetiva poderia atender a demanda atualmente requerida.

Isso se confirma neste estudo, quando foi constatada a transposição de águas da bacia do rio Doce para a bacia do rio Ceará Mirim, (item 8.2.1), através da explotação de uma bateria de sete poços tubulares localizados às margens da lagoa de Extremoz para atendimento do abastecimento público da cidade de Ceará Mirim, localizada no limite destas duas bacias. Portanto, ao comparar as demandas e ofertas entre as bacias vizinhas, do rio Doce e Ceará Mirim, constatou-se a necessidade de um planejamento para uma exploração adequada dos recursos hídricos, nessa região, contemplando uma gestão integrada entre essas unidades hidrográficas.

\section{0 - FUNDAMENTOS E ESTRATÉGIAS PARA O GERENCIAMENTO DAS ÁGUAS SUBTERRÂNEAS NO CURSO INFERIOR DA BACIA DO RIO DOCE}

A grande preocupação mundial envolvendo a comunidade cientifica internacional, governos, ambientalistas e outras entidades é de se encontrar soluções para uma adequada política de gestão das águas. Ela será tanto mais viável quanto mais o modelo de desenvolvimento econômico-social adotado tender a considerar a par do conhecimento da produção dos bens de consumo, a promoção de melhores condições de vida e a preservação da qualidade do ambiente.

Como exemplos a experiência internacional de mais de 25 anos em países como França, Estados Unidos, Alemanha e Japão que, resguardadas as suas peculiaridades, vêm se adequando a uma nova filosofia de gestão de recursos hídricos e ambientais, destacando-se o modelo francês de "agência de bacia". 


\section{1 - Aspectos Conceituais da Gestão dos Recursos Hídricos}

POMPEU (1995), (apud LANNA 1997) define "Recursos Hídricos" como sendo a água destinada a usos; quando se tratar das águas em geral, incluindo aquelas que não devem ser usadas por questões ambientais, o termo correto é apenas "água".

A gestão em si, realiza-se através de procedimentos integrados; de planejamento e de administração. Planejamento é a forma de conciliar recursos escassos e necessidades abundantes. O planejamento dos Recursos Hídricos visa à avaliação prospectiva das demandas e das disponibilidades desses recursos e a sua alocação entre os usos múltiplos, de forma a obter os máximos beneficios econômicos e sociais; (BARTH et al. 1987).

Gestão de recursos hídricos é o conjunto de procedimentos integrados de planejamento e de administração pelo qual procura-se equacionar e resolver as questões de escassez relativa, ou de uso sustentado e proteção de qualidade, (REBOUÇAS, 1997).

LANNA (1997) define a gestão das águas como sendo uma atividade analítica e criativa voltada à formulação de princípios e diretrizes, ao preparo de documentos orientadores e normativos; à estruturação de sistemas gerenciais e à tomada de decisões que têm por objetivo final promover o inventário, uso, controle e proteção dos recursos hídricos. Enfatiza que uma eficiente Gestão das Águas deve ser constituída por uma Política, que estabeleça as diretrizes gerais, um Modelo de Gerenciamento, que estabeleça a organização legal e institucional e um Sistema de Gerenciamento, que contemple os instrumentos para o preparo e execução do Planejamento do uso, Controle e Proteção das Águas .

\section{2 - Aproveitamento das Águas}

A água em abundância, pode ser tratada como bem livre, sem valor econômico. Com o crescimento da demanda surgem os conflitos entre usos e usuários e passa a existir a componente escassez, daí precisa ser entendida como bem econômico, ao qual deve ser atribuído o justo valor. Essa escassez, também pode decorrer de aspectos qualitativos, quando os padrões excedem aos admissíveis para determinados usos. A utilização da água compreende a de caráter consuntivo, que se refere aos usos que retiram a água de sua fonte natural diminuindo as disponibilidades quantitativas, espacial e temporal e a de caráter não consuntivo, que se refere aos usos que retornam à fonte de suprimento, praticamente a totalidade de água utilizada, podendo haver alguma modificação no seu padrão temporal de 
disponibilidade quantitativa. O quadro 9.1 mostra as principais categorias, usos, caráter e efeito da poluição nas águas.

\section{3 - Experiências Internacionais}

A experiência internacional, principalmente a Européia, tem sido alvo como referência para a implantação dos sistemas brasileiros.

\section{Associações Alemãs de Bacias}

Um dos exemplos mais antigos é das Associações de Bacias na Alemanha, como a do Rio Ruhr, estabelecida no início do século. Surgiram de uma concepção adotada pelo Kaiser Guilherme II de que os assuntos sobre a água deveriam ser tratados através de seus próprios usuários, cabendo ao governo apenas o estabelecimento de normas e diretrizes destinadas a ordenar e assegurar o encaminhamento das soluções. A necessidade foi devido ao suprimento de água e energia, e da poluição hídrica, em regiões densamente povoadas e ou industrializadas. Os recursos financeiros para o gerenciamento são provenientes dos próprios membros, alocações do governo e empréstimos.

A direção é exercida por uma Assembléia de representantes eleitos pelos próprios usuários, por um Conselho de Diretores e Representação da Associação, e por um Congresso de Apelação, ao qual são endereçados recursos a deliberações.

\section{Sistema Francês de Gerenciamento das Águas}

O exemplo francês é um dos mais bem sucedidos sistemas de gestão de recursos hídricos no mundo. A França, possui desde o final do século passado, um Código de Águas, um Código Florestal, um Código de Pesca e uma série de regulamentações. Mesmo diante de todo esse aparato jurídico-institucional, em 1964, foi criado um sistema nacional de gestão, com vistas a reverter o processo acentuado de degradação das águas de seus rios, em consequêencia do expressivo desenvolvimento pós guerra. Esta ampla lei das águas mesmo não interferindo nos dispositivos legais anteriores, deu um sentido de conjunto à ação do Estado. 
Quadro 9.1 - Principais usos, caráter e efeitos da poluição nas águas.

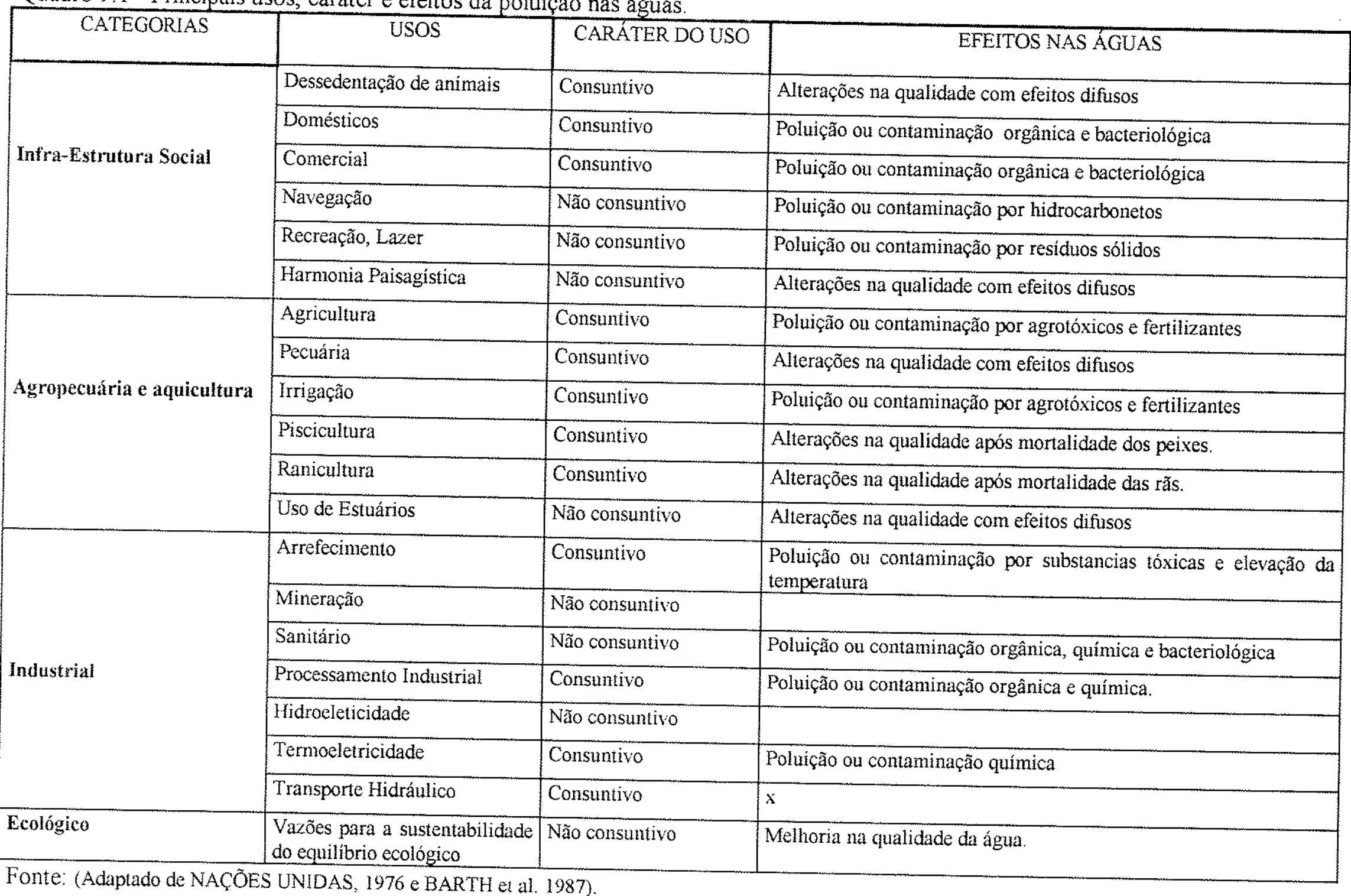


A lei francesa de 64, ao lado de suas normas, decretos e regulamentos é considerada atualmente por especialistas internacionais em recursos hídricos e economistas ambientais como um dos instrumentos mais abrangentes e eficientes em matéria de gerenciamento de recursos hídricos. Os princípios básicos do sistema francês são: gestão por bacia hidrográfica; participação ativa de todos os seguimentos da sociedade; aplicação na prática do princípio do usuário-pagador; cobrança do uso de recursos hídricos, que possibilitam alavancar os investimentos necessários em projetos e obras.

O sistema francês atua em dois níveis: em um primeiro nível, o território francês foi dividido em seis bacias hidrográficas. Em cada uma das bacias há um conjunto de três elementos interatuantes: as Comunas e os Departamentos, a Agência da Água e o Comitê de Bacia. A forma de atuação é iniciada com as Comunas e Departamentos aprovando as classes ou cenários de qualidade para os cursos de água que passem por sua área de domínio, que deverão ser alcançados ao longo dos anos; em seguida vem a atuação da Agência da Água que é o órgão de apoio técnico e administrativo da bacia que tem como principal função realizar os estudos técnicos e econômicos identificando os "pontos negros", apontar os programas de ações de menor custo econômico global para a consecução de tais objetivos e determinar as cotas de contribuição (redevances) sobre os diversos usos da água, necessárias para cobrir uma parcela ponderável dos investimentos planejados; na seqüência do sistema de gerenciamento, vem a atuação do Comitê de Bacia, entidade colegiada composta por políticos, funcionários do governo central e usuários de água, que analisa, discute e solicita modificações para finalmente aprovar as cotas de contribuição. Nesta fase é realizado o cotejo entre o custo da solução e a sua efetividade possibilitando a reavaliação dos cenários estabelecidos. Por fim, a Agência de Água cobra e canaliza as cotas na forma de empréstimos para os diversos agentes (prefeituras, empresas industriais, agricultores, etc) realizarem os investimentos previstos nos programas. O valor arrecadado é a única fonte de recursos financeiros para as Agências de Água. Todo esse processo, aloca anualmente em torno de $0,3 \%$ do PIB à gestão dos recursos hídricos franceses, o que eqüivale a cerca de 30 a $40 \%$ dos investimentos realizados na bacia em obras de controle de poluição (LANNA, 1997).

Os comitês funcionam como Parlamento das Águas e são compostos por 38 representantes eleitos nas comunas e departamentos, 38 representantes dos usuários da água, 20 representantes indicados pelo governo central e 7 representantes de entidades da sociedade civil. A Agência da Água tem um Conselho de Administração designado pelo Comitê, 
formado por 8 representantes das coletividades locais, 8 representantes dos usuários, 8 representantes do Estado e 1 dos funcionários, (ÁGUA VIVA, 1994 apud LANNA, 1997).

Em um segundo plano o Estado faz o monitoramento da qualidade da água de acordo com as solicitações das comunidades afetadas em cada bacia. O Ministério do Meio Ambiente, exerce a tutela sobre as Agências das Águas e os Comitês de Bacia das 6 regiões hidrográficas francesas. O Ministério da Saúde Pública controla a qualidade da água potável e - Ministério da Economia e Finanças regula as tarifas de água.

As diretrizes gerais são controladas pelo governo central e supervisionadas regionalmente no âmbito das Regiões Hidrográficas pelos Comitês Colegiados auxiliados técnica e financeiramente pelas Agencias de Água, o que não impede que o controle direto sobre a execução dos serviços seja descentralizado em aproximadamente 36.000 autoridades locais e comunas, que podem se organizar em consórcios. Dessa forma, o mercado na prestação dos serviços de abastecimento de água e esgotamento sanitário, é bastante competitivo e oligopolizado.

\section{$\checkmark$ Companhia Nacional do Ródano, França}

A Companhia Nacional do Ródano, França foi criada em 1993 para o gerenciamento de projetos de energia, irrigação e navegação do rio Ródano, em sua parte francesa. É uma companhia organizada por ações, cujos participantes são as entidades públicas interessadas no desenvolvimento do Ródano e câmaras de comércio representando interesses privados. A interferência governamental é exercida pela indicação da maioria dos membros do seu Conselho Diretor.

\section{Inglaterra}

Em 1973 o Sistema Inglês de Gerenciamento dos Recursos Hídricos foi atribuído inicialmente a um Conselho Nacional de Águas, que determinaria a estratégia geral do uso dos recursos hídricos, de forma que este Conselho era composto pelas secretarias de Estado para o Meio Ambiente, Ministério da Agricultura, Pesca e Abastecimento e por representações das 10 Superintendências Regionais de Bacia que engloba todo o território. As Superintendências Regionais correspondiam às principais bacias hidrográficas e possuiam responsabilidades sobre o uso, controle e a conservação dos recursos hídricos. Controlavam os gerenciamentos da 
oferta das Águas (quantidade e qualidade), além de interferir no gerenciamento dos usos setoriais, principalmente no abastecimento de água e esgotamento sanitário. Este modelo centralizou as ações executivas tornando as superintendências responsáveis pelo patrimônio, construção, operação e manutenção das obras hidráulicas da bacia. Para cada uma dessas superintendências foi previsto um Conselho de Administração, constituído por representantes das comunidades, das indústrias e dos governos locais e central. Com a reformulação em 1983, o Gerenciamento Interinstitucional foi atribuído às superintendências caracterizando dessa forma uma forte centralização do gerenciamento dos recursos hídricos. Em 1989, as 10 superintendências foram vendidas, através da oferta de ações ao público, tornando-se empresas privadas de capital aberto. O Estado ficou na posse de "ações privilegiadas" (golden shares), com valor simbólico, mas conferindo ao detentor o poder de veto sobre as decisões da assembléia de acionistas. Nesta reforma foram criados:

- o Escritório de Serviços de Água (Office of Water Services), com atribuições no controle do preço da água os anseios dos usuários são viabilizados pelos Comitês Regionais de Serviços dos Consumidores (Consumers Services Committees).

- a Superintendência Nacional de Rios (National Rivers Authority) responsável pelo gerenciamento integrado dos recursos hídricos.

- Divisão de Água Potável (Drinking Water Inspectorate) da Secretaria do Meio Ambiente que monitora a qualidade da água potável.

\section{$\checkmark$ Estados Unidos}

O exemplo de um gerenciamento em regiões com escassez de água, é o Estado da Califórnia, onde $50 \%$ da sua área caracteriza-se por regiões semi-áridas e desérticas. Essa adversidade climática não impediu o sucesso do gerenciamento dos recursos hídricos nestas áreas. Existe o desenvolvimento de uma agricultura irrigada de elevado rendimento e rentabilidade que é a base do desenvolvimento econômico. Existe uma ampla experiência no que se refere a transposição de águas, foram construídas complexas obras para a transposição de águas das bacias dos rios do norte e da bacia do Colorado situada em estado aos vizinhos para o sul da Califórnia. 
Instituiu um sistema nacional de gestão de recursos hídricos, com algumas características do sistema francês, mas difere por ser um sistema centralizador, sendo o domínio das águas exclusivo da união, dificultando o gerenciamento. A gestão é por bacia hidrográfica e o uso destes recursos é cobrado.

\section{4 - Experiência Brasileira}

A prática da administração das águas no Brasil tem demonstrado a despreocupação com a possibilidade da escassez deste recurso. A abundância relativa de água em grande parte das bacias hidrográficas nacionais, permite esse comportamento sem que sofra maiores conseqüências. No entanto, essa situação acompanhada de tal postura não significa inexistência do problema. Os prolongados períodos de seca na região nordeste continuam sem que haja um adequado gerenciamento para uma melhor convivência com este fenômeno natural. O lançamento de esgotos domésticos e industriais sem tratamento degrada a qualidade das águas tornando-as fora dos padrões de consumo e, consequentemente, escassa nas regiões caracterizadas como abundantes neste recurso. Retiradas extraordinárias de água para irrigação geram conflitos entre usuários em várias bacias hidrográficas. Explotações de grande relevância sem controle algum são efetuadas em aquüiferos costeiros provocando intrusões salinas.

Os antecedentes jurídicos da administração dos recursos hídricos no Brasil, remontam às ordenações Filipinas, promulgadas em 1580, quando Portugal estava sob domínio espanhol, mas somente no início deste século o poder público passou a dar alguma importância a um arcabouço legal para as questões dos recursos hídricos. O primeiro projeto de um código de águas data de 1907. Após duas décadas criou-se, no âmbito da comissão legislativa uma subcomissão do "código de águas", com o objetivo de elaborar um novo projeto que finalmente foi aprovado com a promulgação em 10 de julho de 1934.

O Código de Águas Brasileiro é considerado internacionalmente, uma das mais completas leis de águas. É pioneiro em abordar matérias das atuais legislações ambientais. No entanto, falha por atribuir o dominio das águas de superficie exclusivamente às características do curso d'água ignorando a unidade geográfica mais ampla e abrangente a bacia hidrográfica Não considerou a interdependência de domínios e usos impossibilitando uma administração eficaz. A regulamentação dada ao código de águas priorizou os serviços de energia elétrica, favorecendo seu desenvolvimento e o aproveitamento do expressivo potencial de energia 
hidráulica. Os outros setores aguardaram que a regulamentação do código de águas se completasse e retardaram a sua organização. Neste sentido a gestão de recursos hídricos no pais tornou-se fragmentada e descoordenada.

$\mathrm{Na}$ década de 90 houve reformas a nivel federal e estadual, fazendo surgir as bases necessárias para uma gestão integrada dos recursos hídricos. A transformação do Ministério do Meio Ambiente e da Amazônia Legal em Ministério do Meio Ambiente dos Recursos Hídricos e da Amazônia Legal, com competência para a formulação e execução da política nacional do meio ambiente e dos recursos hídricos, constituiu a base para a implantação de um novo modelo de administração dos recursos hídricos no Brasil. Alguns estados antecederam o governo federal no processo de implantação de uma política de recursos hídricos. Até novembro de 1997, sob inspiração da política ambiental reforçada pelas decisões da ECO 92 e da Conferência de Dublin, alguns estados promulgaram a Lei que institui a Política e o Sistema Integrado de Gestão dos Recursos Hídricos, sendo que seis dentre estes estão na região nordeste ( Bahia, Ceará, Paraíba, Pernambuco, Rio Grande do Norte e Sergipe), dois na região sudeste, (Minas Gerais e São Paulo) um na região sul (Rio Grande do Sul) e um na região centro oeste, (Distrito Federal).

A nível de bacia hidrográfica, surgiram até o ano de 1997, os consórcios e associações intermunicipais, voltados para a gestão integrada dos recursos hídricos das bacias, resultante de solicitações das respectivas comunidades. Cita-se, os consórcios e associações das bacias dos rios Piracicaba e Capivari, no estado de São Paulo, e da bacia dos rios Santa Maria da Vitória e Jacu, no Espírito Santo.

\subsection{1 - Arcabouço Jurídico-Institucional Existente}

Para um melhor acompanhamento foi elaborado um resumo da evolução histórica da administração das águas no Brasil:

- 1933 - Criação no Ministério da Agricultura, da Diretoria de Águas, posteriormente transformada em Serviço de Águas e inserido na estrutura do Departamento Nacional da Produção Mineral, DNPM.

- 1934 - Edição do Código de águas que representa um marco na legislação brasileira. Conforme MEIRELLES (1990), o regime jurídico brasileiro das águas internas, nos termos da $1^{\text {a }}$ Conferência de Direito Internacional de Haia, de 1930, é o estabelecido pelo Código de Águas, que dispõe sobre a classificação e utilização das águas e dar ênfase ao aproveitamento 
do potencial hidráulico que na década de 30 representava uma condicionante do progresso industrial no Brasil.

- 1940 - O serviço de Águas tornou-se Divisão de águas (Decreto 6.402/40)

- 1946 - A Constituição de 1946 procurou regulamentar a utilização dos recursos naturais visando à sua exploração econômica. Deu ênfase à livre iniciativa e à propriedade privada e estabeleceu, como competência da União, legislar sobre riquezas do solo, mineração, metalurgia, águas, energia elétrica, florestas, caça e pesca. Permitia que os Estados legislassem sobre águas.

- 1967 - A Constituição de 1967 reforçou mais ainda o caráter de exploração aos recursos ambientais numa visão desenvolvimentista da época.

- 1978 - A Portaria Interministerial nº 90 cria o Comitê Especial responsável pela classificação dos cursos d'água da União, bem como do estudo integrado e do acompanhamento da utilização racional dos recursos hídricos das bacias hidrográficas dos rios federais, no sentido de se obter o aproveitamento múltiplo de cada bacia. A Portaria $\mathrm{n}^{\circ} 1.832$, estabelece que somente serão apreciados pelo Departamento Nacional de Águas e Energia Elétrica os pedidos de concessão ou autorização para derivar águas públicas federais para aplicações da indústria e da higiene que, juntamente com os projetos das obras de derivações, apresentarem sistemas de tratamento dos efluentes aprovados pela Secretaria Especial do Meio Ambiente, (SEMA), do Ministério do interior, ou por órgãos regionais devidamente credenciados pela mesma Secretaria.

- 1979 - A portaria Interministerial n". 003 aprova o regimento do Comitê Especial de Estudos Integrados de Bacias Hidrográficas.

- 1980 a 1984 - Diagnóstico de Bacias Hidrográficas.

- 1984 a 1985 - Alguns Comitês de Bacia evoluem, tais como Paranapanema, Paraíba do sul e Doce.

- 1986 - Resolução do CONAMA ñ. 20, de 18/06/1986 estabelece a classificação das águas doces, salobras e salinas no território nacional em nove classes, segundo seus usos preponderantes.

- 1988 - A Constituição de 1988 dá pouca ênfase às águas, reservando à União a competência para legislar sobre águas e energia. No que se refere ao domínio público, a Constituição Federal manteve como bens da União os lagos e quaisquer correntes de água em terrenos de seu domínio, ou que banham mais de um Estado, constituam limites com outros 
países ou ainda se estendam em território estrangeiro ou dele provenham, bem como os terrenos marginais e as praias fluviais. Permanecem como bens dos Estados "as águas superficiais ou subterrâneas, fluentes, emergentes e em depósito. O critério para a determinação da propriedade do Estado-membro ou da União sobre rios e lagos públicos é o território que estes últimos ocupam. Se a nascente e a foz se localizarem em um só Estado, o rio será estadual. Se seu curso ultrapassar os limites territoriais de um Estado, o rio será federal. Também são consideradas públicas, de uso comum, todas as águas situadas nas zonas periodicamente assoladas pelas secas (Cód. de águas, art. $5^{\circ}$ ) que coincide com o art. 21 (XVIII), da Constituição Federal, que atribui à União competência privativa para organizar a defesa permanente contra os efeitos da seca.

- 1989 - A Lei n ${ }^{\circ} .7 .990$, institui para os Estados, distrito Federal e municípios a compensação financeira pelo resultado da exploração de petróleo ou gás natural, de recursos hídricos para fins de geração de energia elétrica, de recursos minerais em seus respectivos territórios, plataforma continental, mar territorial ou zona econômica exclusiva.

- 1991 - O Poder Executivo encaminha o Projeto de lei $\mathrm{n}^{\circ}, 2.249$, que dispõe sobre a Política Nacional de Recursos Hidricos, cria o Sistema Nacional de Gerenciamento dos Recursos Hidricos e altera a regulamentação do preceito constitucional de compensação financeira pela exploração de petróleo ou gás natural, de outros recursos minerais e de recursos hídricos para fins de geração de energia elétrica (art. $20, \$ 1^{\circ}$, da Constituição Federal).

- 1995 - Foi criado o Ministério do Meio Ambiente, dos Recursos Hídricos e da Amazônia Legal e, neste a Secretaria de Recursos Hídricos, pela MP nº. 813, de 01/01/95.

- 1997 - A Lei n'. 9.433 de 8 de janeiro, institui a Política Nacional de Gerenciamento de Recursos Hidricos e cria o Sistema Nacional de Gerenciamento dos Recursos Hídricos. Este novo modelo da Política de Gerenciamento tem como princípios básicos aqueles praticados atualmente em todos os paises que avançaram na gestão dos seus recursos hídricos, tais como: (i) adoção da bacia hidrográfica como unidade físico-territorial de planejamento; (ii) usos múltiplos integrados; (iii) reconhecimento da água como um bem natural finito, vulnerável, e de valor econômico; (iv) gestão descentralizada e participativa. Esta lei apresenta as bases legais para outorga e cobrança pelo uso da água, como também para a físcalização e as sanções pelo seu uso indevido. 


\subsection{2 - Sistema Nacional Integrado de Gestão dos Recursos Hídricos}

A Lei, 9.433 de 8 de janeiro de 1997, instituiu o Sistema Nacional de Gerenciamento de Recursos Hidricos que tem como objetivos:

i) coordenar a gestão integrada das águas;

ii) arbitrar administrativamente os conflitos relacionados com os recursos hídricos;

iii) implementar a política nacional de recursos hídricos;

iv) planejar, regular e controlar o uso, a preservação e a recuperação dos recursos hídricos;

v) promover a cobrança pelo uso dos recursos hídricos;

A base do funcionamento desse Sistema é a Lei Federal e o conjunto de Leis Estaduais promulgadas a partir de 1991, composto por:

i) uma estrutura federal, compreendendo um Conselho Nacional de Recursos Hídricos e sua Secretaria Executiva, (Secretaria de Recursos Hídricos, do Ministério do Meio Ambiente, dos Recursos Hídricos e da Amazônia Legal);

ii) uma estrutura a ser implantada por bacia hidrográfica em que o rio principal é de dominio federal composta pelo Comitê de Bacia Hidrográfica e pela Agência de Água, ambos organizados segundo a legislação federal;

iii) estruturas estaduais compostas por Conselho Estadual de Recursos Hídricos, o órgão gestor de recursos hídricos, os Comitês de Bacias Hidrográficas e as Agências de Bacia.

A implantação do Sistema deverá ser negociada com base nas articulações entre: o Conselho Nacional e os Conselhos Estaduais, entre a Secretaria de Recursos Hidricos e os órgãos gestores estaduais; entre os Comitês de Bacias de rios de domínio federal a os Comitês Estaduais em sub bacias afluentes a este rio e entre as Agências de Água e as Agências de Bacias estaduais.

BARHT \& POMPEU (1987) alertam para o fato de que nessa estrutura coexistem e se sobrepõem o sistema federativo brasileiro e o sistema nacional de gerenciamento de recursos hídricos. O primeiro prevê a União e as Unidades Federativas autônomas, com águas de domínio federal e estaduais, e o segundo considera o gerenciamento integrado dos recursos hídricos por bacia hidrográfica. Enfatiza que o grande desafio organizacional e político administrativo é fazer com que o Sistema Nacional de Gerenciamento de Recursos Hídricos funcione de forma eficiente e eficaz, conciliando-se com o sistema federativo. 


\section{5 - Experiência no Estado do Rio Grande do Norte}

As questões ambientais do Estado do Rio Grande do Norte sempre foram tratadas pelo Instituto de Desenvolvimento Econômico e Meio Ambiente, (IDEC), atualmente IDEMA, órgão vinculado à Secretaria de Planejamento do Estado, (SEPLAN). Sob o título "Legislação Ambiental do RN', foi publicada em 1998 uma coletânea das normas vigentes que disciplinam a atividade ambiental no Estado e que de uma certa forma incide no tratamento das questões dos recursos hídricos, compreendendo Leis e Decretos.

9.5.1 Leis Ambientais que Antecederam a Legislação Estadual dos Recursos Hidricos:

LEI $N^{*}$ 5.147, de 30 de setembro de 1982 - Dispõe sobre a política e o Sistema Estaduais de Controle e Preservação do Meio Ambiente, e dá outras providências.

LEI $N^{\prime \prime 5.743, ~ d e ~} 30$ de dezembro de 1987 - Disciplina proibição de uso de todo território do RN para depósitos de lixo atômico.

LEI $N^{\circ}$ 6.367, de 14 de janeiro de 1993 - Institui o Plano Estadual de Recursos Hídricos, e dá outras providências;

LEI $N^{0} 6.504$, de $1^{\circ}$ de dezembro de 1993 - Próbe a queimada de cana-de-açúcar num raio de 1.000 (mil) metros de distância da periferia das cidades.

LEI $N^{\circ} 6.621$, de 12 de julho de 1994 - Dispõe sobre o controle da poluição sonora e condicionantes do meio ambiente;

LEI $N^{\circ}$ 6.678, de 21 de julho de 1994 - Cria o Fundo Estadual de Preservação do Meio Ambiente (FEPEMA) e dá outras providências.

LEI $N^{\circ}$ 6.769, de 11 de maio de 1995 - Dispõe sobre a política florestal do Estado do $\mathrm{RN}$ e dá outras providências.

LEI $N^{\circ}$ 6.908, de 01 de julho de 1996 - Dispõe sobre a Política Estadual de Recursos Hídricos e institui o Sisterna Integrado de Gestão de Recursos Hidricos - SIGERH, e dá outras providências.

LEI $N^{0}$ 6.950, de 20 de agosto de 1996 - Dispõe sobre o Plano Estadual de Gerenciamento Costeiro e dá outras providências.

DECRETO $N^{\circ}$ 8.600, de 03 de março de 1983 - Aprova o regulamento da política e sistema estaduais de controle e preservação do meio ambiente. 
DECRETO $N^{\circ}$ 9.100, de 22 de outubro de 1984 - Enquadra cursos e reservatórios d'água do Estado na classificação estabelecida na Portaria no 13, de 15 de janeiro de 1976, do Ministro do Interior, e dá outras providências.

DECRETO $N^{\circ} 10.388$, de 07 de junho de 1989 - Aprova o Plano de manejo do Parque Estadual das Dunas de Natal.

DECRETO $N^{\circ} 10.582$, de 06 de março de 1990 - Cria o sistema de controle ambiental e sanitário do litoral (SCAL), e dá outras providências.

DECRETO $N^{\circ} 10.683$ de 06 de junho de 1990 - Cria a Área de Proteção Ambiental (APA), e dá outras providências.

DECRETO $N^{\circ} 12.620$, de 17 de maio de 1995 - Cria a Área de Proteção Ambiental (APA) Genipabu, nos municípios de Extremoz e Natal e dá outras providências.

DECRETO $N^{\circ} 13.211$, de 09 de janeiro de 1997 - Prorroga a suspensão de licenciamento de construção na Zona Costeira, e dá outras providências.

LEI COMPLEMENTAR $N^{\circ} 140$, de 26 de janeiro de 1996 - Regulamenta os artigos 150 e 154 da constituição estadual e dá outras providências.

\subsubsection{Histórico da Gestão dos Recursos Hídricos no Estado do RN e Atual Arcabouço Juridico e Institucional}

Tradicionalmente a Política de Recursos Hídricos na região nordeste retrata a intervenção do poder público federal no setor. Esse quadro se mantém ao longo de várias décadas e se caracteriza por uma administração centralizadora e fragmentada.

O período de 1825 a 1830 foi marcado por uma prolongada estiagem que impulsionou o início das obras de açudagem no semi-árido nordestino. Em 1831 a Regência Trina autorizou a abertura de fontes artesianas profundas. Na primeira metade do século, com a criação da Inspetora de Fiscalização de Obras Contra as Secas (IFOCS), posteriormente transformada em Departamento Nacional de Obras Contra as Secas (DNOCS), até a década de setenta limitou-se apenas a ampliar a oferta hídrica, através da construção de açudes, construidos através do barramento no leito dos riachos e rios. Em 1959 com a criação da Superintendência de Desenvolvimento do Nordeste (SUDENE), o Estado do Rio Grande do Norte passou a incluir como obras de infra-estrutura-hídrica a construção de poços tubulares, através de convênios celebrados entre a SUDENE e o governo do Estado, na época através da Companhia de Águas e Solos (CASOL ), posteriormente denominada de Companhia de 
Desenvolvimento e Recursos Minerais do Rio Grande do Norte (CDM/RN). A partir do inicio da década de setenta, houve um maior incentivo dos programas governamentais que tinham como objetivo a construção e a instalação de poços tubulares com a finalidade de suprir a demanda humana e animal de água em áreas nunca antes beneficiadas, que se encontravam distantes dos açudes públicos ou rios. Do ponto de vista mercadológico, a construção de poços, era dominada pelo governo, através do DNOCS e da CDM/RN, principalmente devido a inexistência de empresas privadas atuando em perfurações nos terrenos cristalinos.

Entre os anos de 1960 a 1994 a CDM/RN perfurou em todo o Estado cerca de 7000 poços tubulares de modo que nesse periodo não houve a interação com as outras fontes de abastecimento contribuindo para uma subutilização dos recursos disponiveís.

Apesar dos altos investimentos dos recursos federal e estadual na tentativa de ampliar as ofertas hídricas, os resultados dessa forma de administração mostram que o aproveitamento dos recursos hídricos sempre foi realizado de forma a servir aos interesses privados ou da circunstância política, gerando uma falta de gerenciamento integrado que envolvesse o uso múltiplo dos recursos hídricos e uma participação efetiva dos usuários.

Essa visão limitada se reflete nos prolongados periodos de estiagem, quando a única fonte de abastecimento o poço ou o reservatório (açudes e barragens) que não foi gerenciada de forma proativa gera a insustentabilidade desses recursos ao atendimento das demandas, instalando-se situações caóticas, afetando principalmente a saúde das populações atingidas pela escassez, já que nestas situações o abastecimento d'água ocorre através de carros pipas, condutores em potencial de doenças de veiculação hídrica.

Em 1994 foi elaborado o relatório "Potencialidades Hidrogeológicas do Estado do Rio Grande do Norte", para o Projeto Áridas, onde os técnicos da divisão de hidrogeologia da Companhia de Desenvolvimento de Recursos Minerais do Rio Grande do Norte (CDM/RN), sugeriram uma definição no papel desempenhado pelos órgãos envolvidos com os recursos hídricos do Estado, solicitando dos poderes competentes uma estrutura efetiva e uma política definida.

Em 1995 foi criada a Subsecretaria de Recursos Hidricos e Projetos Especiais, (SERHPE), posteriormente Secretaria de Recursos Hídricos (SERHID), onde foi iniciado um trabalho por uma equipe técnica composta por geólogos, engenheiros civis e agrônomos, cujo objetivo inicial foi colocar em discussão, a questão da administração das águas, colocando em prática algumas providências urgentes e necessárias ao desempenho do próprio trabalho. Com o desenvolvimento dos debates em torno do tema "Gestão de Recursos Hídricos" e inspirando- 
se nos primeiros resultados do Gerenciamento Integrado dos Recurso Hídricos no estado do Ceará, notadamente com uma realidade econômica e social semelhante ao estado do Rio Grande do Norte, foram tomadas as primeiras decisões: "o novo modelo" de administração estadual das águas deveria estar assentado sobre o estabelecimento de um arcabouço institucional, a criação do aparato legal e a elaboração do Plano Estadual de Recursos Hidricos.

Dentro deste contexto foi analisada a situação do Estado, e verificou-se uma administração desorganizada com interferência de vários órgãos e conseqüente superposição de atividades na área dos recursos hídricos, gerando uma administração incapaz de implantar um gerenciamento efetivo de um Estado com $90 \%$ do seu território em condição de semiaridez.

Diante desta situação a implementação de uma adequada política de gestão das águas adquire um valor estratégico e, consequentemente, um dever do poder público. Neste sentido, foi criado um aparato jurídico institucional através da Lei 6.908, aprovada em 01 de julho de 1996, que dispõe sobre a Política Estadual de Recursos Hidricos e institui o Sistema Integrado de Gestão de Recursos Hídricos (SIGERH).

É uma lei de trinta artigos, resultado de um minucioso estudo das leis de outros estados, como o do Ceará e de São Paulo, adaptada à realidade do Estado, que define como objetivos: o planejamento, desenvolvimento e gerenciamento de forma integrada, descentralizada e participativa no uso múltiplo, controle, e conservação dos recursos hídricos, assegurando que a água seja utilizada em padrões de quantidade e qualidade satisfatória. Os instrumentos de política e gerenciamento estão definidos no art $4^{\circ}$ e compreende: o Plano Estadual de Recursos Hídricos, (PERH), o Fundo Estadual de Recursos Hidricos (FUNERH), a Outorga do Direito de Uso dos recursos hídricos, o Licenciamento de Obras Hídricas, e a Cobrança pelo Uso da Água.

$\checkmark$ PERH - aprovado por lei, estabelece as diretrizes gerais sobre o aproveitamento dos recursos hídricos e será revisto e atualizado a cada quatro anos e inserido no Plano Plurianual de Desenvolvimento do Estado, de forma a assegurar a integração setorial em seus aspectos sociais, econômicos e ambientais.

hidricos. Os recursos financeiros do FUNERH deverão ser depositados em conta especifica aberta em Banco Oficial e movimentada através do seu gestor. São definidas as seguintes aplicações para com os recursos do FUNERH: 
- realização de planos, programas, projetos e pesquisas com vistas ao desenvolvimento, conservação, uso racional e sustentável, controle e proteção dos recursos hídricos superficiais e subterrâneos;

- execução de obras e serviços com vistas ao desenvolvimento, conservação, uso racional e sustentável, controle e proteção dos recursos hídricos superficiais e subterrâneos;

- programas e estudos com vistas à capacitação de recursos humanos, pesquisas e desenvolvimento tecnológico de interesse da gestão dos recursos hídricos;

- implementação das atividades de gestão dos recursos hídricos dos órgãos participantes do SIGERH.

\section{$\checkmark$ Outorga de Direito de Uso da Água}

A possibilidade de concessão do uso e exploração de um manancial decorre do Código de Águas de 1934. Atualmente, a outorga é vinculada à jurisdição das águas. No estado do Rio Grande do Norte foi regulamentada pelo decreto 13.283 de 22 de março de 1997, que norteia princípios fundamentais, como: (i) prioridade para o abastecimento humano; (ii) o aceso a água constitui direito de todos para as primeiras necessidades da vida; (iii) a distribuição da água no território do Rio Grande do Norte obedecerá a critérios sociais, econômicos e ambientais; (iv) o uso da água será compatibilizado com as políticas federal e estadual de desenvolvimento urbano e rural.

\section{$\checkmark$ Cobrança pelo uso da água}

De acordo com o Cap. Il, art.16 a cobrança pelo direito de uso da água, superficial ou subterrânea, é um instrumento gerencial e de planejamento da política estadual de recursos hídricos que visa conferir racionalidade ao uso e a valorização econômica dos recursos hídricos. É o elemento de maior impacto na implementação da legislação de recursos hídricos no Brasil. O princípio que rege a cobrança é o equilíbrio entre a oferta e a demanda, consequentemente este equilibrio de mercado é um forte instrumento para evitar o desperdício e induzir ao aproveitamento racional dos mananciais.

O regulamento estabelecerá os procedimentos relativos à cobrança pelo direito de uso da água, a ser implementada, de forma gradual, de acordo com condicionamentos econômicos e sociais dos usuários dos recursos hídricos. O cálculo do custo da água, para efeito de cobrança, considerará:

(i) a classe de uso preponderante em que for enquadrado o corpo de água objeto do uso; 
(ii) a função social e econômica da água;

(iii) as condições sócio-econômicas dos usuários;

(iv) o grau de regularização assegurado por obras hidráulicas

(v) a operação e manutenção da infra-estrutura hídrica e amortização do investimento realizado.

No caso de utilização de corpos de água para diluição, transporte e assimilação de efluentes, os responsáveis pelos lançamentos ficam obrigados ao cumprimento das normas e padrões relativos ao controle de poluição das águas.

As obras de uso múltiplo, de interesse comum ou coletivo, terão seus custos rateados por todos os seus beneficiários diretos.

\subsubsection{1 - O Sistema Integrado de Gestão de Recursos Hídricos}

O Sistema Integrado de Gestão dos Recursos Hídricos (SIGERH), regulamentado através do Decreto ${ }^{\circ} 13.284$ de 22 de março de 1997, compreende os seguintes órgãos Condutores da Política Estadual de Recursos Hídricos: o Conselho Estadual de Recursos Hídricos (CONERH), os Comitês de Bacias Hidrográficas e a Secretaria de Recursos Hídricos (figura 9.1).

- Conselho Estadual de Recursos Hídricos (CONERH) - constitui a instância maior de deliberação do sistema integrado de gestão dos recursos hídricos do Estado e compete às seguintes atribuições:

i) aprovar e acompanhar o Plano Estadual de Recursos Hídricos;

ii) estabelecer os critérios e diretrizes que orientam a Política Estadual de Recursos Hídricos;

iii) promover a articulação entre os órgãos estaduais, federais e municipais e a sociedade civil no encaminhamento da política estadual de recursos hídricos;

iv) deliberar sobre a criação de Comitês de Bacias Hidrográficas; arbitrar, em grau de recurso, os conflitos existentes entre bacias hidrográficas ou entre usuários de água;

v) estabelecer critérios gerais para cobrança pelo uso dos recursos hídricos;

vi) deliberar sobre a criação e funcionamento das agências de Bacias Hidrográficas;

vii) deliberar sobre as questões que the tenham sido encaminhadas pelos Comitês de Bacias Hidrográficas. 


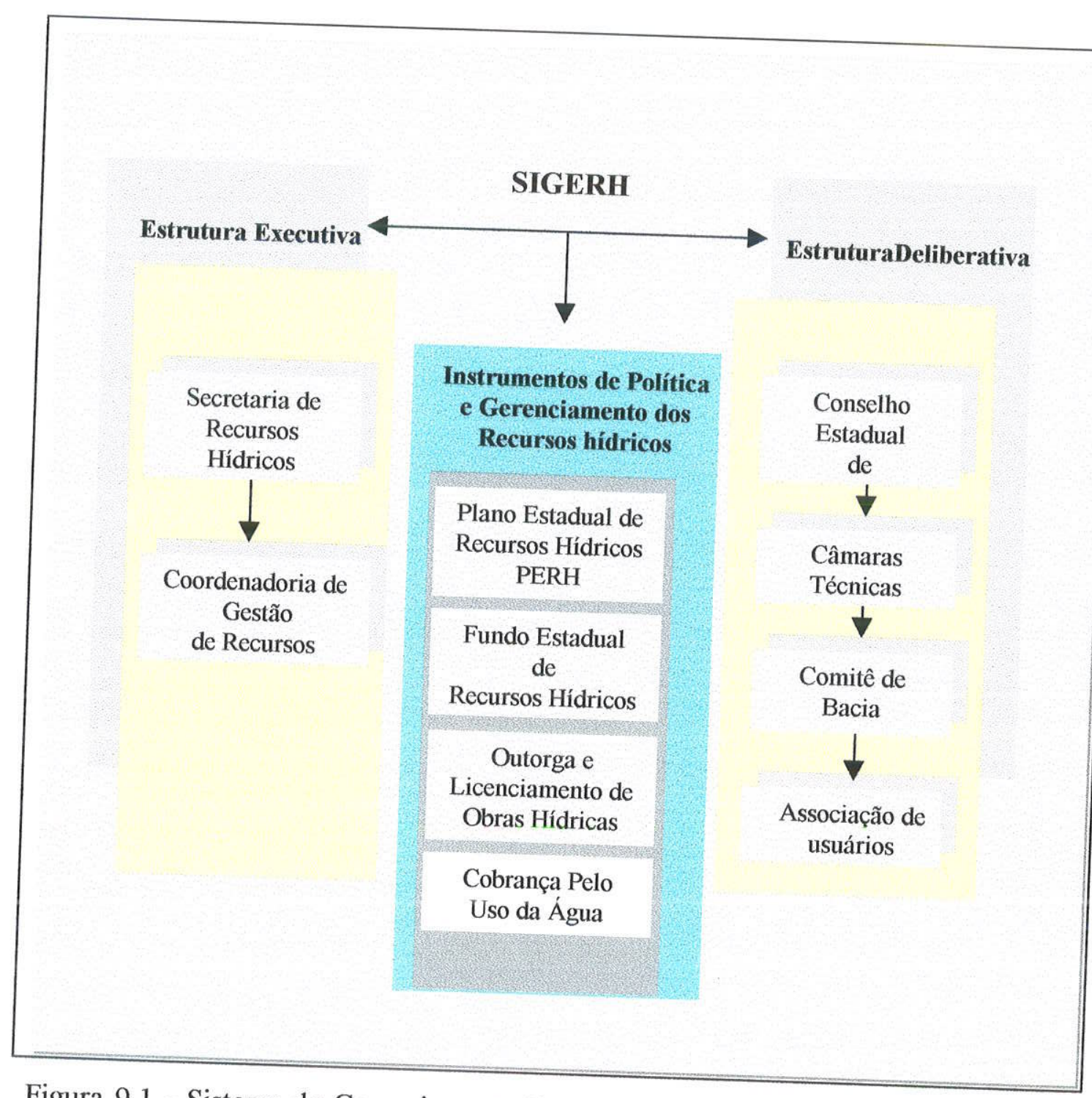

Figura 9.1 - Sistema de Gerenciamento Integrado dos Recursos Hídricos do Estado do Rio Grande do Norte

Fonte: (CASTRO, 2000)

- Comitês de Bacias - órgãos colegiados de atuação descentralizada e têm por objetivo:

i) congregar os usuários de água das bacias hidrográficas;

ii) atuar junto ao conselho estadual de recursos hídricos - CONEHR

iii) colaborar com o poder público na administração dos Recursos Hídricos do Estado do Rio Grande do Norte.

- Secretaria de Recursos Hídricos, (SERHID) - é o núcleo gestor que constitui a instância executiva maior da política estadual de recursos hídricos, regulamentada através do decreto 13.285 de 22 de março de 1997, cujo organograma atual está apresentado na figura.9.2. 


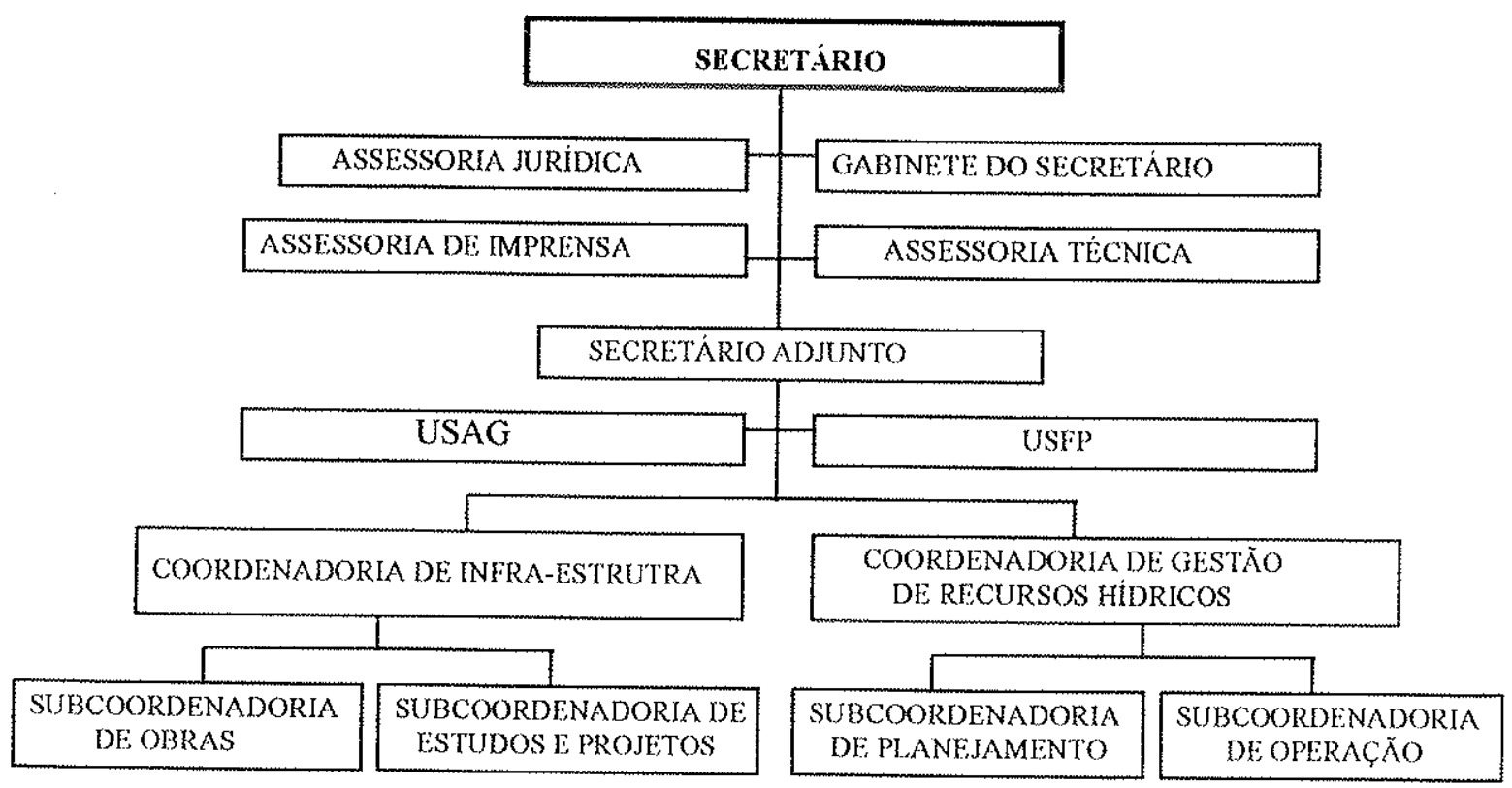

Figura 9.2 - Estrutura organizacional da Secretaria dos Recursos Hídricos do Estado do Rio Grande do Norte

Fonte: (SERHID)

\section{6 - Estratégias Para a Implementação da Gestão das Águas Subterrâneas no Curso Inferior da Bacia do Rio Doce}

O gerenciamento dos recursos hidricos além de envolver um conjunto de procedimentos integrados de planejamento e administração, requer o conhecimento da unidade hidrográfica, sob vários aspectos, tais como: a sua condição sócio-econômica, seu condicionamento físico (geologia, clima, hidrologia, hidrogeologia), uso e ocupação do solo, ofertas e demandas dos recursos hídricos e os anseios dos usuários.

O quadro 9.2 resume o que foi levantado na bacia do Rio Doce e a partir deste diagnóstico preliminar associado ao arcabouço jurídico e institucional existente no Estado do Rio Grande do Norte foi possível elaborar algumas sugestões para o início da implantação de um Sistema de Gerenciamento Integrado dos Recursos Hídricos na bacia estudada. O diagnóstico realizado indicou o seguinte quadro:

Normalmente ao se constatar os problemas gerados pelo mal uso dos recursos naturais, os setores envolvidos com a problemática tendem a querer sanar de imediato o efeito. No entanto, tem-se verificado que os melhores resultados provêm de medidas que envolvam a sociedade fazendo-a ser participativa no processo. 
Quadro 9.2 - Resumo do diagnóstico realizado na Bacia do Rio Doce

\begin{tabular}{|c|c|}
\hline Potencial da Bacia Hidrográfica & Problemas Verificados \\
\hline $\begin{array}{l}\text { - Elevado potencial hídrico subterrâneo, } \\
\text { concentrado principalmente no curso } \\
\text { inferior da bacia, com águas de excelente } \\
\text { qualidade; } \\
\text { - Apenas } 10 \% \text { da área da bacia apresenta } \\
\text { problemas com escassez, concentrado no } \\
\text { seu curso superior; } \\
\text { - Relevante produção de fruticulturas, } \\
\text { (côco, banana, caju, manga, acerola e } \\
\text { produtos hortigrangeiros, sendo } \\
\text { referencial de abastecimento para o } \\
\text { comércio local); } \\
\text { Concentra as indústrias de maior porte do } \\
\text { Estado do RN; } \\
\text { Solos com grande potencial para o } \\
\text { desenvolvimento do cultivo da } \\
\text { fruticulturas; } \\
\text { Se faz presente o ano inteiro, as fontes de } \\
\text { energia solar e eólica; } \\
\text { Região com expressivo } \\
\text { paisagistico, representados pelas dunas, } \\
\text { rios, lagoas e mar, em processo de } \\
\text { desenvolvimento turistico; } \\
\text { Temperaturas estáveis (24,4\% a } 26,5^{\circ} \text { ), } \\
\text { durante todo o ano. } \\
\text { Compreende parcialmente } \\
\text { municipios, com estruturas de escolas, } \\
\text { secretarias de educação e saúde, para } \\
\text { atuar nos programas de educação } \\
\text { ambiental. }\end{array}$ & $\begin{array}{l}\text { Desconhecimento, por parte dos } \\
\text { usuários, do potencial hídrico subterrâneo } \\
\text { e dos efeitos impactantes a que estão } \\
\text { submetidos, por parte dos usuários; } \\
\text { - Falta de saneamento básico; } \\
\text { - Desperdício de água no curso inferior da } \\
\text { bacia; } \\
\text { - Lançamento de lixo diretamente no solo } \\
\text { em vários pontos da bacia; } \\
\text { Execução de obras hídricas (barramentos, } \\
\text { poços tubulares, desvios dos cursos de } \\
\text { água), sem a licença prévia do órgão } \\
\text { gestor dos recursos hídricos; } \\
\text { Falta de dados hidrometeorológicos; } \\
\text { Falta de monitoramento dos corpos } \\
\text { d'água; } \\
\text { Incidência de doenças de veiculação } \\
\text { hídrica, esquistossomose, cólera, hepatite } \\
\text { viral e verminoses. }\end{array}$ \\
\hline
\end{tabular}

Fonte: (CASTRO, 2000)

De acordo com os exemplos de gerenciamento dos recursos hídricos no mundo, tem-se constatado que os modelos que foram bem sucedidos adotaram, inicialmente, a concepção de que os assuntos sobre a água deveriam ser tratados junto aos seus usuários, tendo a bacia hidrográfica como unidade de gestão e leis aplicáveis.

O modelo brasileiro vem adotando estes princípios e no caso particular do Rio Grande do Norte existem exemplos de algumas bacias hidrográficas que estão correspondendo positivamente, principalmente no que se refere a participação dos usuários neste processo. 
No caso específico da Bacia do Rio Doce, com diversidades climáticas e sócioeconômicas, bem caracterizadas, torna-se necessária a representação dos anseios da população, através das associações dos usuários de água e comitês de bacias. Junto a esta estrutura é indispensável a implementação das licenças dos poços tubulares e da outorga do direito de uso da água subterrânea.

\subsection{1 - Associação dos Usuários}

São organizações livremente criadas pelos usuários de um determinado corpo d'água sem fins lucrativos, com prazo de duração indeterminado e com responsabilidade fiscal perante os Governos Federal, Estadual e Municipal. É uma entidade autônoma, criada e organizada democraticamente, sem nenhuma vinculação político-partidária e isenta de qualquer ingerência do Órgão Gestor dos Recursos Hidricos e de outras Instituições Governamentais e/ou Estrangeiras.

Apresentam como objetivos gerais:

(i) desenvolver a capacidade da bacia para atingir soluções integrais e sustentáveis dos seus problemas de ambiente e saúde;

(ii) colaborar com o poder público estadual na administração dos corpos d'água, para o efetivo controle do fornecimento de água aos associados, em quantidade e qualidade compativeis com suas necessidades;

(iii) defender os direitos dos associados junto ao poder público, especialmente nas questões referentes ao atendimento de suas necessidades de água;

(iv) fortalecer a organização, promovendo a efetiva participação de seus associados em campanhas de educação, levantamento de dados e outras iniciativas do poder público, para a gestão de recursos hídricos, na área de sua jurisdição;

(v) participar de campanhas educativas de preservação ambiental promovidas na comunidade; participar da limpeza dos corpos d'água, através dos usuários associados à mesma, contribuindo para a sua preservação, conservação e controle das doenças de veiculação hidrica e participar de atividades para formação e funcionamento do Comitê de Bacia. Para alcançar seus objetivos, a associação poderá assumir compromissos formais, com entidades públicas ou privadas, sem perder a individualidade e poder de decisão, (RÊGO, 1999). 


\subsubsection{1 - Estratégias}

Mecanismos de participação dos usuários deverão ser gerados para fazer com que as autoridades e os setores representativos da população possam conhecer e decidir sobre os problemas existentes, as prioridades e os enfoques para resolvê-los.

Deverá ser incluída a exposição de soluções graduais e sustentáveis para resolver os problemas de ambiente e saúde e a promoção do uso de uma tecnologia compativel com a realidade e cultura. A finalidade será gerar mudanças de conduta para fazer com que a população adote estilos de vida viáveis que possibilitem que as cidades inseridas na bacia sejam sustentáveis.

Na estrutura e desenvolvimento dos projetos será considerada sua projeção a nivel de gerenciamento nacional e regional para obter resultados que sirvam como modelo às outras bacias com problemas similares.

\subsubsection{2 - Metodologia de Implementação}

a) Para uma melhor organização da associação é fundamental que seja criado um Estatuto Social que compreende o regimento interno da entidade, constituindo um documento sintético, elaborado pela própria comunidade e apresentado em Assembléia Geral de Constituição da Associação, para debate e aprovação.

b) instalação de uma Comissão Organizadora Provisória (COP) com os seguintes objetivos:

(i) iniciar o processo de criação da Associação de Usuário de Água;

(ii) elaborar o anteprojeto do Estatuto Social, que deverá ser submetido à aprovação da Assembléia Geral;

(iii) elaborar o edital de convocação para a realização desta Assembléia;

(iv) preparar toda a documentação necessária à constituição da futura associação.

Esta Comissão deverá funcionar como um colegiado, tomando decisões por consenso e dividindo as responsabilidades igualmente. Todo este processo deverá ser acompanhado pelo órgão gestor dos recursos hídricos.

De acordo com o Modelo de Gestão dos Recursos Hídricos adotado pelo Estado do RN, cabe a Secretaria de Recursos Hídricos (SERHID), orientar os membros da Comissão Organizadora, a fim de que sejam efetuados corretamente todos os passos legais e gerenciais, para a organização da entidade, porém não estará presente à Assembléia Geral de Constituição da Associação. Esta será uma das claras demonstrações de que a Secretaria nunca adotará uma 
postura intervencionista ou tuteladora. Atualmente o programa de associações de usuários de água da SERHID, orienta que sejam seguidas as seguintes providencias:

a) através de uma Assembléia Geral de Constituição da Associação dos Usuários de Água será escolhido o seu presidente;

b) aprovado o Estatuto Social o presidente proclamará constituída a associação e convida os presentes a procederem a eleição dos membros da Diretoria Executiva e Conselho Fiscal;

c) concluida a votação e apuração dos votos, o presidente da Assembléia proclamará nominalmente os eleitos, indicando os respectivos cargos e declara-os empossados;

d) está oficialmente constituída a associação, investidos os membros da Diretoria Executiva e do Consetho Fiscal, registrados em ata, podendo a Assembléia ser encerrada. A ata deve ser subscrita por todos os presentes. A SERHID expedirá um "CERTIFICADO DE CREDENCIAMENTO", admitindo-a oficialmente como interlocutora válida junto ao Governo do Estado;

e) constituída a associação, o passo seguinte será a preparação da documentação da entidade objetivando o seu perfeito funcionamento. O registro da Associação deverá ser feito no cartório da cidade, no livro "B - Das Pessoas Jurídicas", que deverá ser pleiteado pelo presidente da entidade, em requerimento formal, anexando a este a cópia do $\mathrm{ClC}$, Carteira de Identidade, do Estatuto Social, da Ata de Constituição da Associação e a relação de todos os membros da Diretoria Executiva e do Conselho Fiscal, contendo os nomes completos, endereços e número da carteira de identidade e órgão emissor. Todos os documentos deverão ser apresentados sem rasuras ou emendas. Nessa fase a SERHID poderá prestar as orientações necessárias;

f) se algum trabalho da associação não for inteiramente voluntário e a entidade tiver que admitir um único emprego, deverá passar a recolher INPS, FGTS e PIS, apresentar Relação Anual de Informações Sociais - RAIS, preencher Ficha de Registro de Empregados - FRE e organizar os arquivos dessa documentação;

g) a diretoria deverá solicitar a inserção da associação na Receita Federal do Estado para obtenção de sua inscriçăo no Cadastro Geral de Contribuintes - CGC;

h) A associação criada, independentemente do seu porte, deve contar, obrigatoriamente, com livro caixa, livro de matrícula dos associados e livros de atas das reuniões de Diretoria, Conselho Fiscal e Assembléias Gerais;

i) concluída a fase documental, a diretoria deve concentrar seus esforços no aparelhamento da entidade para o seu normal funcionamento. 
A estrutura organizacional para o funcionamento da gestão dos recursos hídricos na bacia do rio Doce está representada na figura 9.3, sugerindo a implantação de uma associações de usuários e um comitê de bacia.

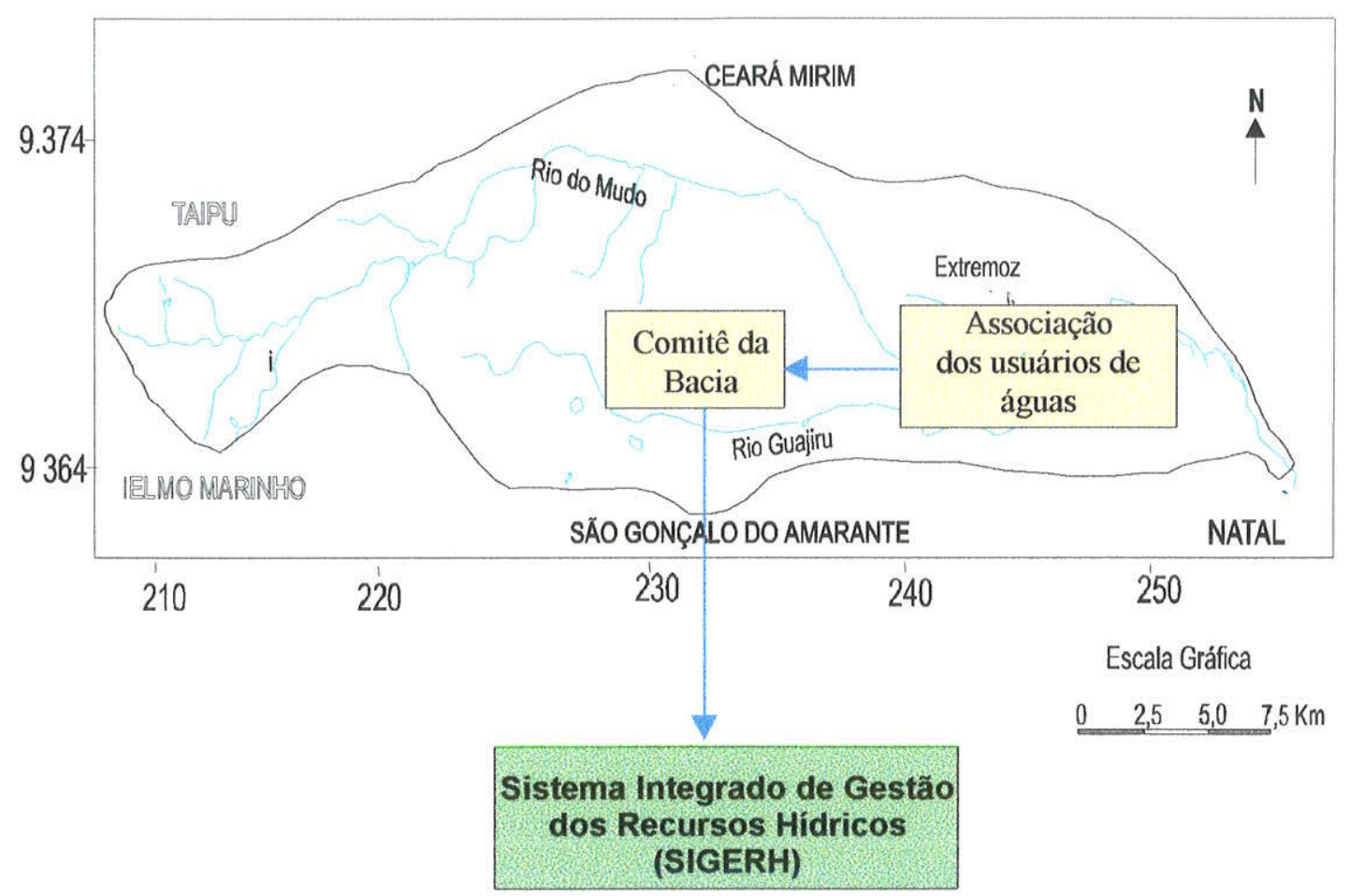

Figura 9.3 - Unidades básicas de apoio ao gerenciamento integrado dos recursos hídricos na bacia do rio Doce Fonte: (CASTRO, 2000)

\subsubsection{Comitê de Bacia}

A atual política de recursos hídricos contempla como principal estratégia a descentralização das decisões e ações, sendo os comitês de bacia sua maior expressão. Estes comitês visam a gestão e definição de políticas regionais de recursos hídricos e tem como diretriz definir as prioridades para a sustentabilidade ambiental da bacia.. Os resultados das discussões regionais deverão gerar o plano da bacia. Os comitês são constituídos por representantes dos municípios, estado e sociedade civil.

OLIVEIRA (1998) trata da experiência da implantação de um processo de gestão ambiental dos recursos hídricos, na Bacia do Mogi-Guaçu e do Pardo, SP, em que as águas subterrâneas é o recurso estratégico.

No Brasil, as regiões onde as águas subterrâneas têm essa importância, requerem maior habilidade, com relação à implementação de programas específicos de planejamento e 
gestão para estes mananciais, devido o vácuo institucional, consequentemente são raros os comitês de bacia que priorizam a gestão para estes recursos.

Essa situação, propicia o extrativismo das águas subterrâneas nos setores privado e público, de modo que qualquer indústria, condomínio, irrigante ou indivíduo pode perfurar um poço na sua propriedade sem nenhum controle federal, estadual ou municipal e, freqüentemente, sem tecnologia apropriada. Em conseqüência, aumentam o risco de contaminação, as interferências indesejadas e as super-explotações de água nos aquúferos. No caso do comitê do Mogi-Guaçu (CBH-Mogi), foi um dos primeiros do Estado de São Paulo a priorizar as águas subterrâneas como recurso estratégico e agir nesta direção. Tal experiência relatada por OLIVERRA (1998), mostra que mesmo o estado de São Paulo dispondo de uma legislação de águas subterrâneas (lei n ${ }^{\circ} 6.134 / 88$ ), os primeiros desafios já estão sendo revelados, na implementação dos comitês de bacias direcionados para as águas subterrâneas. Como exemplos são citados a assimetria de informação e o desnivelamento técnico e institucional entre os participantes, principalmente do poder público estadual, no que tange aos processos decisórios.

O estado do Rio Grande do Norte, ainda não dispõe de uma legislação para as águas subterrâneas, embora já esteja contemplada no Programa de Gestão dos Recursos Hidricos Estadual. No entanto, isto não impede a criação de comitês direcionados para a gestão destes mananciais.

Com base no diagnóstico realizado no âmbito deste trabalho, sugere-se algumas prioridades para discussões no Comitê da Bacia do Rio Doce (CBRD).

Tendo sido instalado o comitê poderão ser inicialmente realizados alguns fóruns que tratem dos seguintes temas:

(i) realidade sócio-econômica đa bacia;

(ii) a potencialidade do aqüífero Barreiras, sua importância como insumo básico no desenvolvimento regional e os impactos de uma super-explotação;

(iii) comportamento das ofertas e demandas do aquüifero;

(iv) a forma que está sendo ocupado o solo, as principais fontes de contaminação e seus impactos nas águas subterrâneas;

(v) incidência das doenças de veiculação hídrica na bacia;

(iv) os usuários do respectivo aquüifero;

(v) a Política Estadual de Gestão dos Recursos Hidricos e o funcionamento do Sistema Integrado de Gestão dos Recursos hídricos (SIGERH); 
(vi) a legislação estadual de recursos hidricos

A realização destes fóruns possibilitará ao comitê conhecer o comportamento da área sob os principais aspectos que interferirão nas tomadas de decisões e servirá de base para a elaboração do Plano de Gestão da Bacia. Recomenda-se, que na sede do comitê, no curso inferior da bacia, disponha de todas informações e dados para consulta dos seus usuários.

\subsection{3 - Concessão de Licença Para Construção de Obras de Infra Estrutura Hídrica}

O Decreto $\mathrm{N}^{\circ}$ 13.283, de 22 de março de 1997, em seu Art. 23. consta que sem prejuizo de outras licenças exigíveis, dependerá de licença prévia da Secretaria de Recursos Hidricos (SERHID) a implantação, ampliação e alteração de projeto de qualquer empreendimento que demande a utilização de recursos hídricos, superficiais e/ou subterrâneos, bem como a execução de obras ou serviços que alterem o seu regime em quantidade e /ou qualidade. A licença prévia será expedida, mediante parecer técnico, após exame dos documentos de que trata o artigo 28 deste regulamento, autorizando a implantação de obra ou serviço de oferta hídrica, de acordo com as especificações do projeto aprovado.

$\mathrm{Na}$ bacia do rio Doce as principais estruturas hidráulicas consistem em poços tubulares e cacimbões. No curso inferior estas obras captam água do meio poroso, (aqüifero Barreiras). O poço tubular ou cacimbão deverá ser construido atendendo as normas técnicas características de uma obra de engenharia geológica, hidráulica e sanitária. Neste sentido sugere-se que as seguintes informações façam parte do processo de requerimento da licença da obra:

\section{1) Informaçôes sobre o empreendimento:}

1.1) Identificação da empresa responsável pela perfuração do poço, e do responsável técnico de nível superior com seus respectivos registros do CREA e ART da obra;

1.2) Finalidade da obra;

1.3) Beneficios a serem alcançados

\section{2) Informaçóes sobre a área do projeto:}

2. 1) situação em relação a bacia hidrográfica, municipios, núcleos urbanos;

2.2) situação em relação a corpos de água superficiais;

2.3) situação em relação a lagoas de estabilização, postos de combustivel; cemitérios, lixões, distritos industriais, áreas irrigadas, fossas e outras fontes potenciais de poluição;

2.4) croqui com a localização do poço, cota do terreno e coordenadas geográficas.

3) Informaçôes Hidrogeológicas: 
3.1) levantamento de poços existentes e respectivas vazões extraídas, no local e circunvizinhanças;

3.2) estimativas de parâmetros hidráulicos do aqüifero a ser explotado

3.3) em caso de grandes projetos (abastecimento público, indústrias ou irrigação), indicar: número de poços previstos; distância entre os poços, e interferências previstas;

3.4) para os poços que serão utilizados no abastecimento público, deverão ser apresentadas as Áreas de Proteção de Poços, $\left(\mathrm{APP}_{\mathrm{S}}\right)$, cujas normas técnicas deverão constar na legislação das águas subterrâneas;

\section{4) Informações sobre a obra de captação:}

4.1) estimativa da profundidade do poço;

4.2) método de perfuração a ser empregado;

4.3) diâmetro de perfuração;

4.4) estimativa da vazão do poço;

4.5) previsão da coluna litológica;

4.6) previsão da provável posição dos niveis estático e dinâmico;

4.7) caracterização da natureza e previsão da granulometria do pré-filtro;

4.8) tipo, diâmetro e estimativa de revestimento de tubos lisos e filtros;

4.9) indicação do trecho previsto de cimentação sanitária;

4.10) indicação do tipo de desinfecção do poço;

9.6.3.1 - Especificações Técnicas e Construtivas

No médio e baixo curso da bacia, (aqüifero Barreiras), foram identificadas expressivas variações litológicas, nas fichas técnicas dos poços, nesse sentido recomenda-se que as amostras dos estratos perfurados, devam ser coletadas a cada 2,0 metros ou a cada mudança litológica.

i) A lama de perfuração nos poços perfurados pelo método rotativo com circulação direta deve ter seus parâmetros físicos e químicos controlados durante os trabalhos, com a finalidade de evitar danos ao aqüífero e facilitar a limpeza do poço.

ii) Quando os poços forem locados em áreas urbanizadas, verificar nos poços já existentes a possivel presença de nitrato. 
iii) O desenvolvimento do poço deve ser efetuado através da combinação de métodos de acordo com as características do aqüifero, até que a turbidez e concentração de areia atinjam limites admissíveis.

iv) Os testes de bombeamento devem ser realizados com equipamentos adequados, evitando a utilização de compressor de ar comprimido. Recomenda-se os seguintes cuidados:

- para facilitar a medição de níveis durante a execução dos testes, sugere-se que seja instalada uma tubulação-guia de $3 / 4$ "até a profundidade destinada à câmara de bombeamento, que poderá ficar definitivamente instalada para monitoramento do poço;

- a duração do teste de bombeamento deve ser no mínimo de 24 horas;

- no caso dos testes escalonados devem ser realizados em etapas de mesma duração, com vazões progressivas, em regime contínuo de bombeamento, mantendo-se a vazão constante em cada etapa.

vi) A coleta de amostras de água para análise físico-química deve ser realizada durante a execução dos testes de bombeamento, em frascos de pelo menos um litro devidamente lavado com água do poço. As amostras para análise bacteriológica devem ser coletadas em frascos esterilizados fornecidos por laboratório de análises. O período entre a coleta e a entrega no laboratório não deve ser superior a 24 horas.

vii) Concluidos os testes de bombeamento, deverá ser feita a cimentação sanitária, compreendida no espaço anular entre o tubo de revestimento e a parede de perfuração.

O diagnóstico da bacia do rio Doce caracterizou que o abastecimento público através de poços tubulares é a fonte mais segura, tendo em vista a garantia da oferta e que os corpos d'água superficiais são regularizados através do sistema aqüifero Dunas/Barreiras.

O perfil sócio econômico do Estado do Rio Grande do Norte realizado pelo INSTITUTO DE DESENVOLVIMENTO E MEIO AMBIENTE (IDEMA, 1997), mostrou que dois dos municípios que estão inseridos na bacia do rio Doce, estão entre os municípios que apresentaram maior crescimento populacional. O município de São Gonçalo do Amarante com uma taxa de crescimento populacional de $4,56 \%$ ao ano é o terceiro municipio na classificação da análise da densidade demográfica apresentando $217,14 \mathrm{hab} / \mathrm{km}^{2}$. O município de Extremoz com uma taxa de crescimento populacional de 3,58\% ao ano, apresenta-se na sétima posição entre os 150 municípios quando analisado sobre o aspecto da densidade demográfica com $131,66 \mathrm{hab} . \mathrm{km}^{2}$.

No entanto, à medida que aumenta o crescimento populacional há consequentemente um aumento das fontes dispersas de contaminação, que diz respeito às 
fossas sépticas e esgotos, já que estes municipios não dispõe de saneamento básico. Foi verificado no curso inferior da bacia, que embora os teores de nitrato em muitos pontos do aqüifero não tenham atingido níveis elevados, a tendência geral observada é de aumento. Trabalhos realizados na grande Natal, com características hidráulicas semelhantes as da área citada, (CASTRO, 1994) e (MELO, 1995 1998), tem revelado que o número de poços contaminados por nitrato não têm cessado de crescer.

Portanto, restringir o uso do terreno em torno dos poços de captação para o abastecimento público, constitui uma das formas de se evitar contaminações indesejadas. Os primeiros trabalhos científicos que estabelecem estas áreas de proteção datam da década de trinta, (KNOR, 1937 apud SCHILEYER et al. 1992) e as primeiras experiências foram na Europa no século passado.

Nos Estados Unidos para assegurar a qualidade da água bombeada em poços ou bateria de poços para abastecimento público, foi criado o Programas de Proteção de Poços (Wellhead Protection Program), PPP, através de emendas ao Safe Drinking Water Act (SDWA), em junho de 1986. Este programa visa delinear as denominadas "áreas de proteção de poços" (Wellhead Protection Areas), APP, para todas as obras de captação da rede de abastecimento público daquele país. As emendas de 1986 requisitam de cada estado americano a preparação de um PPP, designam o United States Environmental Protection Agency (U.S.EPA) o órgão responsável pela orientação técnica no desenvolvimento do PPP e estabelecem o prazo de 3 anos para a sua apresentação (CLEARY, 1992).

Porém, diante da constatação dos indícios de contaminação das águas subterrâneas na região será de relevante conveniência a inserção das delineações das denominadas áreas de proteção de poços para todos as unidades de captação de águas subterrâneas destinadas ao abastecimento público. Estas áreas de proteção poderão fazer parte da documentação dos requerimentos de licenças para a construção de poços. O quadro 9.3, mostra os exemplos de aplicações de métodos de delineamento das Áreas de Proteção de Poços (APP) e locais onde foram utilizados. 
Quadro 9.3 - Aplicações de métodos de delineamentos de APP

\begin{tabular}{l|l}
\hline MÉTODOS PARA DELINEAÇÃO DAS APPS & LOCAIS ONDE FORAM UTULIZADOS \\
\hline Raio Fixo Arbtrário & Nebraska, Flórida, Cape Cod, Massachusetts \\
Raio Fixo Calculado & Flórida, Vermont \\
Formas Variadas Simplificadas & Sul da Inglaterra \\
Métodos Analíticos & Cape Cod, Massachusetts, Alemanha Oriental, Holanda \\
Mapeamento Hidrogeológico & Vermont, Connecticut, Cape Cod, Massachusetts \\
Modelos Numéricos de Fluxo/Transporte & Sul da Flórida, Cape Cod, Massachusetts \\
\hline
\end{tabular}

Fonte: (Traduzido e modificado de U.S.EPA, 1988 apud CLEARY, 1992)

\subsubsection{2 - Metodologia Para a Expedição de Licenças Para Obras Hídricas}

A expedição de licenças para obras hídricas no Estado do Rio Grande do Norte compreende o seguinte processo de tramitação:

O requerente solicita a outorga, em formulário padrão adequado ao seu uso, sob protocolo do Órgão Gestor (atualmente Secretaria de Recursos Hídricos), que encaminha à Coordenadoria de Gestão de Recursos Hídricos (COGERH), para instrução do processo e esta por sua vez encaminha à Subcoordenadoria de Planejamento (SUPLAN). Uma análise preliminar do pleito é realizada e nesta fase é verificado se o processo consta apenas de uma consulta ou se é a licença propriamente dita. Em caso de consulta a SUPLAN emite parecer havendo duas situações: se o parecer for favorável a equipe técnica da SUPLAN encaminha o processo para a COGHER com os devidos esclarecimentos para a elaboração do projeto; no caso do parecer ser negativo, a decisão denegatória é comunicada ao requerente. Quando se tratar do próprio requerimento de licença a equipe técnica concluirá se o projeto e os documentos são satisfatórios ou não para a análise técnica, havendo nesta fase duas alternativas:

\section{Informações Insuficientes:}

Quando o requerimento não apresentar as informações suficientes, a COGERH através de correspondência solicita a reformulação do projeto e/ou a complementação das informações.

\section{Informações Suficientes:}


No caso da análise preliminar concluir pela suficiência de informações, a equipe técnica da COGERH realizará a análise técnica para a emissão de um parecer que apresentará, duas situações:

\section{Parecer Não Favorável}

O parecer técnico ao recomendar a não expedição da licença, será encaminhado a COGERH, que comunicará ao requerente a decisão denegatória do seu pedido de licença. $\mathrm{Da}$ decisão denegatória da licença caberá recurso administrativo ao Conselho Estadual de Recursos Hídricos - CONERH, em última instância administrativa, no prazo de 15 (quinze) dias, contados da data da efetiva ciência ao interessado. Quando houver interposição de recurso, a COGERH deverá reunir o CONERH, para apreciação da matéria e tomará providências a cerca das suas deliberações, na qualidade de Secretaria Executiva do Conselho.

\section{Parecer Favorável}

Nesta condição, o parecer técnico ao recomendar a expedição, a COGERH, expedirá a licença através de portaria que será publicada no Diário Oficial do Estado. A figura 9.4 apresenta o fluxograma dos procedimentos de licenciamento de obras hidráulicas.

\subsubsection{Concessão de outorga}

\subsubsection{1 - Aspectos Conceituais}

Outorgar significa consentir, aprovar, dar o direito. A outorga do direito de uso dos recursos hídricos constitui um forte instrumento de gestão, pois quando se pratica a outorga está se permitindo ter o conhecimento e o controle dos múltiplos usos da água. O uso desse instrumento de gestão dos recursos hídricos requer um embasamento técnico, e conhecimento dos problemas relacionados a cada bacia hidrográfica. É necessário que exista um aparato jurídico que estabeleça a ordem de dominância desses recursos hídricos e reafirme o caráter público e inalienável das águas. Este aparato jurídico contêm as "normas estruturais" que determinam a matriz básica de direitos sobre os recursos hidricos. As definições de dominialidade e as modalidades de outorga de concessões para exploração de recursos hídricos são as principais normas estruturais existentes no Direito Brasileiro em matéria de água.

O fundamento legal das outorgas encontra-se estabelecido no artigo 42 do Código de Águas, cujas normas foram contempladas pela Constituição Federal, e consolidadas com a lei Federal n 9.433 , de 8 de janeiro de 1997. 


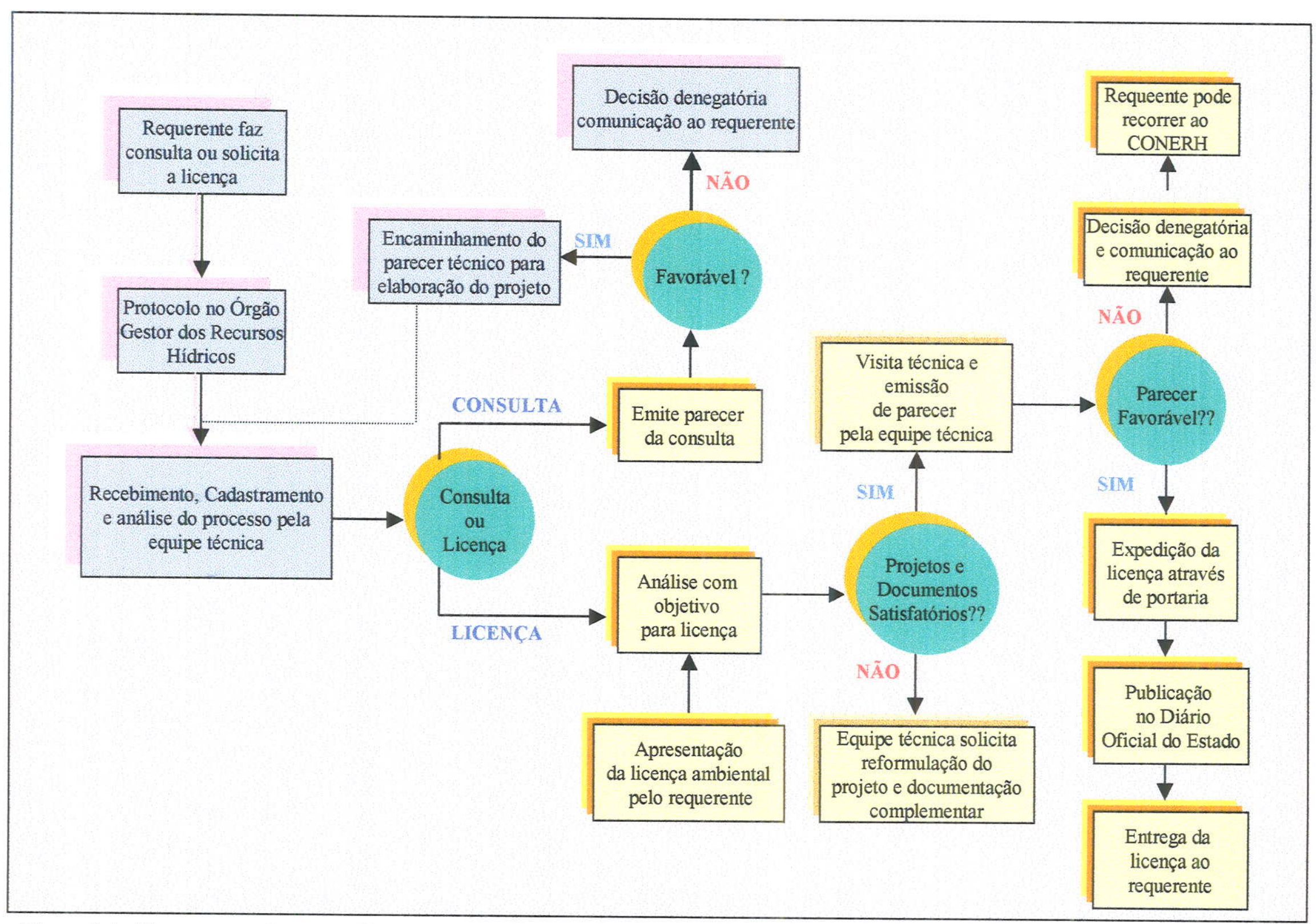

Figura 9.4 - Fluxograma dos procedimentos para licenciamento de obras hidráulicas Fonte: (SERHID) 
A lei federal $9.433 / 97$, no que se refere à outorga do direito de uso da água especifica que a outorga será efetivada por ato da autoridade competente do poder executivo federal, dos Estados ou do Distrito Federal. O poder Executivo Federal deverá articular-se com os Estados e o Distrito Federal na outorga de águas de bacias sob o dominio federal e estadual, podendo também delegar aos mesmos competência para conceder a outorga em corpos de água sob o domínio da união, (art. 15).

As ações que envolvem a outorga do direito de uso e licenciamento dos recursos no Estado do Rio Grande do Norte, teve início com o Decreto n"13.283, de 22 de março de 1997, que regulamenta o inciso III do art. $4^{\circ}$ da lei $n^{\circ} 6.908$, de $1^{\circ}$ de julho de 1996 , que dispõe sobre a Politica estadual de Recursos Hídricos, e dá outras providências.

De acordo com a legislação vigente, a outorga confere ao usuário o direito de uso de determinada vazão ou volume de água, de uma fonte especifica, para um certo uso, por um período definido, em condições intransferiveis. Dentro deste contexto a concessão da outorga requer uma sistemática de avaliação. A bacia do rio Doce concentra a maior diversidade de usos no seu curso inferior, através da exploração dos poços tubulares e da lagoa de Extremoz.

De acordo com os dados levantados, foi verificado que o consumo atual de águas subterrâneas (aqüífero Barreiras), da bacia do rio Doce, é da ordem de $21,6 \times 10^{6} \mathrm{~m}^{3} / \mathrm{ano}$, ( capítulo 8.0). No balanço das entradas e saídas de água no sistema lacustre foi estimado um aporte de água subterrânea para a lagoa de $17 \times 10^{6} \mathrm{~m}^{3} /$ ano. Considerando este volume e as retiradas de águas captadas dos poços tubulares verifica-se que a demanda total atual de águas subterrâneas, é de aproximadamente $38,6 \times 10^{6} \mathrm{~m}^{3} / \mathrm{ano}$, o equivalente a $50 \%$ das reservas reguladoras do sistema aqüifero Dunas/Barreiras no curso inferior da bacia do rio Doce.

Sob o ponto de vista das águas subterrâneas (aqüifero Barreiras) na bacia hidrográfica do rio Doce, verifica-se que há uma necessidade de gerenciamento intensiva, considerando que as demandas estimadas para o ano de 2010 atingirá uma cifra da ordem de $59,4 \times 10^{6} \mathrm{~m}^{3} /$ ano, o equivalente a $70 \%$ das reservas reguladoras

Face à relevante importância da outorga como instrumento de gestão, são apresentadas, algumas sugestões que poderão fazer parte dos procedimentos na sistemática de avaliação da outorga de águas subterrâneas no curso inferior da bacia do rio Doce.

9.6.4.2 Outorgas Para os Poços Tubulares Com Finalidade Para o Abastecimento Público, Administrados Pelas Empresas Concessionárias 
As outorgas para águas subterrâneas serão precedidas pelo processo de licenciamento dos respectivos poços de exploração. Em relação aos poços construídos com antecedência à nova legislação, estes deverão ser inseridos no banco de dados do órgão gestor através do cadastro realizado no âmbito deste trabalho, anexo 01 e das suas futuras atualizações.

O abastecimento humano, tanto na legislação estadual como na federal, é considerado "uso prioritário das águas", fazendo com que seja objeto de uma análise criteriosa.

$\mathrm{Na}$ área em questão o consumo atual de água subterrânea (sistema aqüúfero Dunas/Barreiras) destinado para o uso humano é da ordem de $14,6 \times 10^{6} \mathrm{~m}^{3} / \mathrm{ano}$, sendo que $12,3 \times 10^{6} \mathrm{~m}^{3} / \mathrm{ano}$, são explorados pelas empresas concessionárias, o correspondente a $57 \%$ de todo o volume explotado do aqüífero Barreiras no curso inferior da bacia

Atualmente os poços tubulares gerenciados pelas concessionárias estão concentrados na margem da lagoa de Extremoz (Ponta Grossa), compreendendo uma bateria de 07 poços tubulares e no bairro de Gramoré, englobando um conjunto de 12 poços tubulares. O maior problema diagnosticado foi a presença de nitrato, no bairro de Gramoré, que em alguns poços tubulares, os teores já superam o limite de $45 \mathrm{mg} / \mathrm{L}$. É recomendável que neste caso o Órgão Gestor dos Recursos Hídricos exiga como parte dos documentos estudos especificos sobre a evolução dos teores de nitrato no local, indicando a fonte e as possíveis soluções do problema. É de suma importância que no processo do pedido da concessão da outorga sejam indicadas as áreas de proteção (APP), destes poços.

A comisão técnica responsável pela análise do pedido de outorga definirá o período da concessão de acordo com as informações prestadas, através dos estudos realizados, de forma que as renovações das outorgas estejam atreladas aos estudos requisitados pelo órgão gestor.

Nos casos dos poços tubulares que após todas as providencias tomadas, continuarem a apresentar teores acima de $45 \mathrm{mg} / \mathrm{L}$, $\mathrm{NO}_{3}^{-}$, (limite estabelecido pela Organização Mundial de Saúde) recomendarse que sejam desativados, evitando dessa forma que esses respectivos poços atuem como fonte de contaminação.

As renovações das outorgas também deverão estar atreladas às informações de monitoramento dos níveis dos poços. No caso da fonte de água subterrânea em questão (aquüffero Barreiras), estas medições poderão ser realizadas no mínimo a cada 15 dias. Esta forma viabilizará um trabalho em parceria com as empresas concessionárias no monitoramento do aqüífero. Estas informações serão inseridas no banco de dados do órgão gestor que serão 
constantemente interpretadas, permitindo o desenvolvimento de uma metodologia prática e confiável de outorga. Da mesma forma serão exigidas nos pedidos de outorga as análises físicas, químicas e bacteriológicas. Estas análises deverão ser inseridas no banco de dados da bacia do rio Doce com a finalidade de acompanhar a evolução da qualidade das águas subterrâneas.

\subsubsection{3- Outorgas Para os Poços Tubulares Com Finalidade Para o Uso Industrial}

A disponibilidade de água de boa qualidade e com altos niveis de garantia de fornecimento, faz com que a área em apreço seja atrativa para a instalação de atividades industriais, principalmente no que se refere as indústrias de bebidas e alimentos. $O$ pólo industrial de Extremoz tem perspectiva de ampliação para os próximos dez anos. Atualmente o consumo real de águas subterrâneas para o distrito industrial de Extremoz é de $5,7 \times 10^{6}$ $\mathrm{m}^{3} / a$ no, representando $27 \%$ do volume total de águas subterrâneas explotado atualmente na bacia. As inđústrias estão instaladas no extremo leste da bacia, se posicionando a uma distancia de aproximadamente 8 quilometros da linha de costa.

Portanto, tratando-se de uma área costeira, é necessária a realização de estudos específicos no que se refere ao comportamento da cunha salina. Em várias regiões do mundo existem problemas de gestão de recursos hídricos, associados com a explotação de aqüiferos costeiros. Intensas pesquisas estão sendo realizadas com o objetivo de entender e controlar o mecanismo de avanço da cunha salina do oceano para o continente e assim obter orientações para o gerenciamento das explotações de água subterrânea em aqüiferos costeiros. Na china a intrusão de água salgada vem ocorrendo desde 1960 e tem aumentado gradualmente a partir da década de 80, (XUE et al. 1991). A primeira rede de observação da intrusão marinha neste país foi instalada na região da baia de Laizhóu (Província de Shandong), em 1988, onde a situação estava tornando-se grave. O estudo visava avaliar o impacto antrópico na intrusão de água do mar e o desenvolvimento de um modelo de transporte soluto tridimensional a fim de predizer a intrusão. Foi constatada a ocorrência de uma interface abrupta relacionada aos poços de bombeamento que estão concentrados e o fluxo é relativamente estável, (exemplo típico em indústrias e bateria de poços para abastecimento público, (WU, J. et al. 1993).

Dentro desse contexto, em que uma bacia costeira concentra um polo industrial em desenvolvimento, é necessário que o programa de gestão dos recursos hídricos contemple informações sobre este assunto nas indústrias, com o objetivo de que os dirigentes se 
conscientizem que o principal produto “a água” poderá ser afetado em um futuro próximo, vindo a comprometer a sustentabilidade das referidas unidades industriais.

Portanto, será de grande valia o monitoramento deste aqüífero direcionado para o estudo da intrusão marinha de forma a ser realizada uma parceria entre as unidades industriais, as concessionárias e o órgão gestor. Neste sentido, visando a viabilidade e sustentabilidade deste programa de monitoramento sugere-se a vinculação deste às concessões e renovações das outorgas às indústrias.

\subsubsection{4 - Outorgas Para os Poços Tubulares Com Finalidade Para o uso na Irrigação}

As informações prestadas quanto ao tipo de cultura e a quantidade de fertilizante aplicada é de suma importância, tendo em vista que alguns pesquisadores têm sugerido que as taxas de lixiviação sejam expressas em termos da proporção de perdas da carga aplicada. Devendo-se considerar que o nitrato lixiviado dos fertilizantes é resultado da acumulação de nitrogênio total no solo e somente uma menor parte provém diretamente dos fertilizantes aplicados para o mesmo ano agrícola (HIRATA, 1994).

As questões associadas ao método de irrigação escolhido, principalmente o turno de rega e a eficiência esperada na aplicação do mesmo, são os pontos críticos na determinação da demanda hídrica. A equipe técnica responsável pela análise do pedido de outorga, deverá priorizar a melhoria na eficiência, sinalizando para os usuários a necessidade de diminuir perdas e melhorar as técnicas de irrigação.

Mudanças nas práticas agrícolas têm sido recomendadas, com o objetivo de diminuir a carga de fertilizantes nas águas subterrâneas: como o controle das taxas de irrigação, evitando o excesso hídrico, (HUBBARD et al. 1984); uso de compostos que inibam a oxidação de fertilizantes por microorganismos (BREMNER et al. 1986); uso alternado do solo por plantações de leguminosas e não leguminosas, com aplicação de fertilizantes orgânicos e não orgânicos (CAST, 1985 apud ALLER'T et al. 1987).

A equipe técnica responsável pela análise do pedido de outorga, deverá delimitar os corpos de águas superficiais que poderão sofrer impactos dos fertilizantes e definir períodos para que sejam realizadas análises das águas para a verificação da presença de possiveis contaminantes provenientes das atividades agrícolas. Durante a visita técnica, deverão ser cadastrados os poços que estejam na área do projeto de irrigação. As renovações da outorga estarão vinculadas às informações do monitoramento dos niveis de água destes poços e as 
respectivas análises das águas a serem exigidas no processo da concessão da outorga. O quadro 9.4 lista os compostos fertilizantes usualmente utilizados e seus respectivos comportamentos em subsuperficie.

\subsubsection{5 - Metodologia da Expedição de Outorgas}

A expedição de outorgas no Estado do Rio Grande do Norte compreende o seguinte processo de tramitação;

O requerente solicita a outorga, em formulário padrão adequado ao seu uso, sob protocolo do órgão Gestor dos Recursos Hidricos, atualmente Secretaria dos Recursos Hídricos (SERHID) que encaminha a Coordenadoria de Gestão de Recursos Hídricos COGERH, para uma análise preliminar e que concluirá se as informações prestadas são suficientes ou não para a análise técnica, havendo nesta fase duas alternativas:

\section{Informações Insuficientes:}

Quando o requerimento não apresentar as informações suficientes, a COGERH através de correspondência solicita a complementação das informações.

\section{Informacões Suficientes:}

No caso da análise preliminar concluir pela suficiência de informações, a equipe técnica realizará a análise técnica da demanda, diligenciando todas as ações cabiveis para a emissão de um parecer que apresentará, naturalmente, duas situações:

\section{Parecer Não Favorável}

O parecer técnico ao recomendar a não expedição da outorga será encaminhado a COGERH, que de acordo com o Gabinete, comunicará ao requerente a decisão denegatória do seu pedido de outorga. Da decisão denegatória da outorga caberá recurso administrativo ao Conselho Estadual de Recursos Hidricos (CONERH), em última instância administrativa, no prazo de 15 (quinze) dias, contados da data da efetiva ciência ao interessado. Quando houver interposição de recurso, a COGERH deverá reunir o CONERH, para apreciação da matéria e tomará providências a cerca das suas deliberações, na qualidade de Secretaria Executiva do Conselho

\section{Parecer Favorável}

Nesta condição, o parecer ao recomendar a expedição da outorga, a COGERH realizará o cadastramento definitivo da outorga e fará a preparação de toda a documentação necessária, que juntamente com o Gabinete, expedirão a outorga através de portaria que será 
publicada no Diário Oficial do Estado. A figura 9.5 apresenta o resumo do procedimento que os processos de requerimento de outorgas estão submetidos.

Quadro 9.4 - Resumo das caracteristicas dos principais fertilizantes agricolas.

\begin{tabular}{|c|c|c|c|c|c|c|c|}
\hline \multirow[t]{2}{*}{ Tipo } & \multirow[b]{2}{*}{$\begin{array}{l}\text { Adsorção } \\
\text { no Solo }\end{array}$} & \multicolumn{2}{|c|}{ Mobilidade no Solo } & \multicolumn{2}{|c|}{ Transformação } & \multicolumn{2}{|c|}{$\begin{array}{c}\text { Possiveis } \\
\text { Contaminantes } \\
\end{array}$} \\
\hline & & Cátions & Ấnions & Quim. & Biol. & Cátions & Ânions \\
\hline De Nitrogênio & & & & & * & $\mathrm{NH}^{4}$ & $\mathrm{NO}^{3} ; \mathrm{NO}^{4}$ \\
\hline Nitrato de Calcio & baixo, s/e Ca & baixa & Alta & & * & $\mathrm{NH}^{4}$ & $\mathrm{NO}^{3} ; \mathrm{NO}^{4}$ \\
\hline Salitre de Amônio & parcial s/e $\mathrm{NH}^{4}$ & baixa & Alta & & * & $\mathrm{NH}^{4}$ & $\mathrm{NO}^{3} ; \mathrm{NO}^{4}$ \\
\hline Salitre de Sódio & baixa s/e $\mathrm{Na}$ & baixa & Alta & & * & $\mathrm{NH}_{2}^{4}$ & $\mathrm{NO}^{3} ; \mathrm{NO}^{4}$ \\
\hline Salitre de Potássio & baixa s/e K & baixa & Alta & & * & $\mathrm{NH}^{4}$ & $\mathrm{NO}^{3} ; \mathrm{NO}^{4}$ \\
\hline Salitre de Amônio e Cal & aumento $\mathrm{NI}^{4}$ & baixa & Alta & & * & $\mathrm{NIF}^{4^{4}}$ & $\mathrm{NO}^{3} ; \mathrm{NO}^{4}$ \\
\hline Sulfato de Amônio & parcial s/e NHA & baixa & Média & & * & $\mathrm{NH}^{4}$ & $\mathrm{NO}^{3} ; \mathrm{NO}^{4}$ \\
\hline Amoníaco Líquido & aita $\mathrm{NH}^{4}$ & baixa & Alta & * & & $\mathrm{NII}^{4}$ & $\mathrm{NO}^{3} ; \mathrm{NO}^{4}$ \\
\hline Água amoniacal & parcial $\mathrm{NH}^{4}$ & baixa & Alta & * & & $\mathrm{NH}^{4}$ & $\mathrm{NO}^{3} ; \mathrm{NO}^{4}$ \\
\hline Uréia & parcial $\mathrm{NH}^{4}$ & baixa & Ala & * & & $\mathrm{NI}^{4}$ & $\mathrm{NO}^{3}, \mathrm{NO}^{4}$ \\
\hline Cianamida Cálcica & parcial $\mathrm{NII}^{4}$ & baixa & Alta & * & & $\mathrm{NH}^{4}$ & $\mathrm{NO}^{3} ; \mathrm{NO}^{4}$ \\
\hline \multicolumn{8}{|l|}{ De Fósforo } \\
\hline Surfosfato & muito alta & Extema e baixa & & & & & $\mathrm{HPO}^{4}$ \\
\hline Surfosfato Granulado & muito alta & Extrema e baixa & & * & & & $\mathrm{HPO}^{4}$ \\
\hline Tri-Superfosfato & muito alta & Extrema e baixa & & * & & & $\mathrm{HPOO})^{4}$ \\
\hline rosfato Pulverizado & muito alta & Extrema e baixa & & * & & & $\mathrm{HPO}^{4}$ \\
\hline Pó de Thomas & muito alta & Extrema e baixa & & & & & $\mathrm{HPO}^{4}$ \\
\hline Superfosfato simples & muito alta & Extremá e baixa & & * & & & $\mathrm{HPO}^{4}$ \\
\hline + Fosfato Cru & & & & & & & \\
\hline De Potássio & & & & & & & \\
\hline Cloreto de Potássio & baixa, s/ \& K & baixa & alta & & & K & $\mathrm{Cl}$ \\
\hline Cloreto de Potássio & baixa, s/ e K & baixa & baixa & & & $\mathrm{K}$ & $\mathrm{Cl}$ \\
\hline \multicolumn{8}{|l|}{ Sulfato de magnésio } \\
\hline Kainit & baixa, s/ e K & baixa & alta & & & k & $\mathrm{Cl}$ \\
\hline Sulfato de Potássio & baixa, s/e K & baixa & média & & & $\mathrm{K}$ & $\mathrm{Cl}$ \\
\hline NPK combinado & aumentada & baixa & alta & * & * & K & $\mathrm{NO}^{3} ; \mathrm{NO}^{4}$ \\
\hline
\end{tabular}

Fonte: (VRBA \& ROMIJN, 1986 ) 


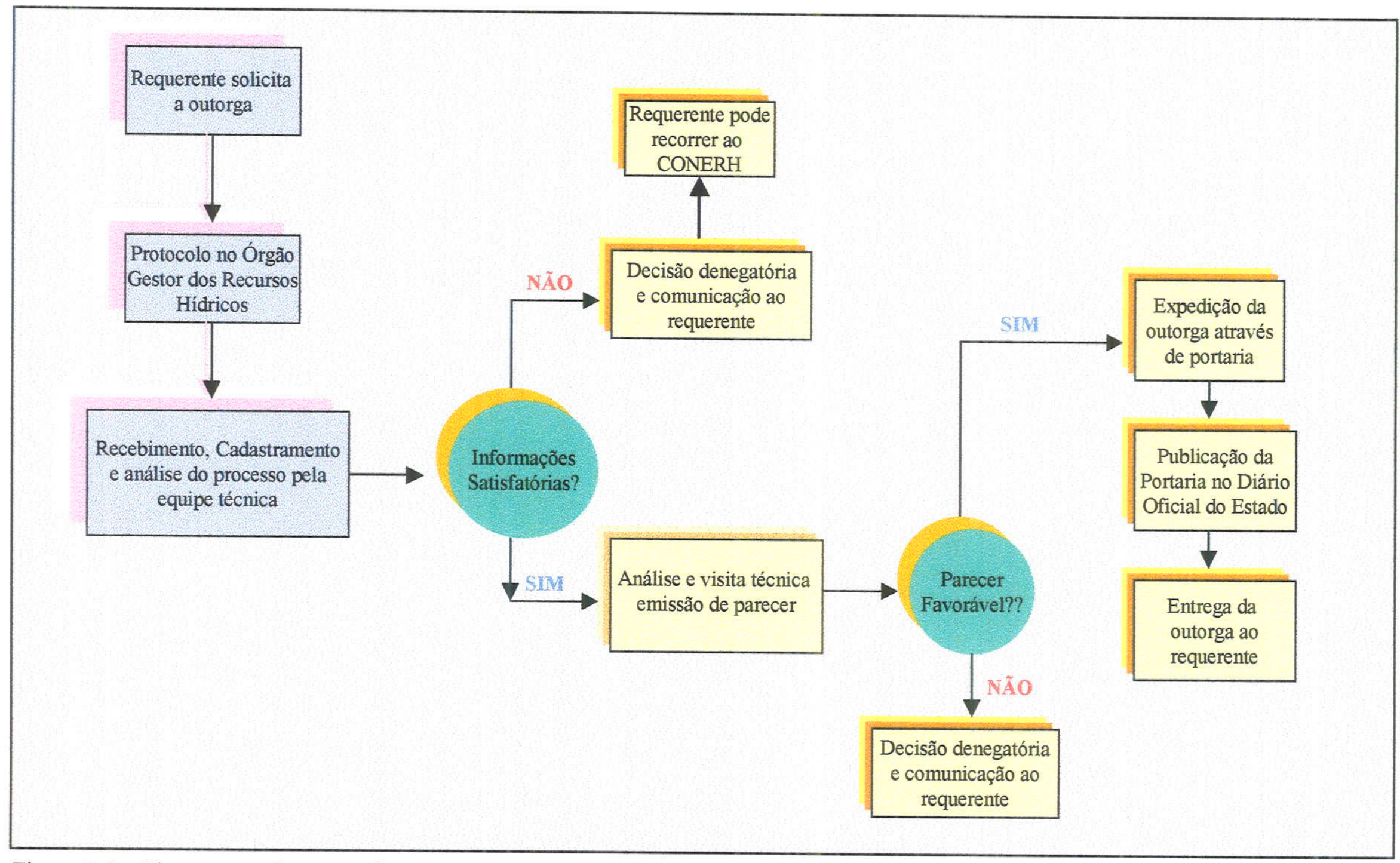

Figura 9.5 - Fluxograma dos procedimentos para a expedição da outorga do direito de uso da água Fonte: (SERHID) 


\section{0 - CONCLUSÕES E RECOMENDAÇÕES}

Na última década houve uma evolução extraordinária no que se refere a modelos de gerenciamento dos recursos hídricos, colocando a disposição dos especialistas novas técnicas e ferramentas que vêm ajudar nas tomadas de decisões, facilitando as soluções de conflitos. No entanto, apesar da disponibilidade de excelentes modelos computacionais os pesquisadores enfrentam sérios problemas no que se refere à falta de dados hidrológicos nas bacias hidrográficas gerando incertezas que comprometem o gerenciamento dos recursos hidricos, tendo em vista que não existem métodos confiáveis para estimativa de disponibilidade hídrica na ausência de dados, prejudicando os estudos de avaliação da qualidade das águas e os de apoio à instituição de processos de outorga. Em conseqüência, devido às avaliações incorretas, pode-se considerar viável um aproveitamento inviável ou o inverso

A tomada de decisão no gerenciamento dos recursos hídricos requer técnicas adequadas e firmeza na aplicação dos critérios legais de proteção de direitos prioritários e de projeções reais para o futuro. Portanto, inicialmente é necessário, ter no mínimo, o conhecimento da bacia hidrográfica do ponto de vista de seu comportamento climático, hidrológico, hidrogeológico, uso e ocupação do solo, qualidade da água, usuários dos recursos hídricos, ofertas e demandas. Dentro deste contexto, este estudo contemplou uma primeira parte que foi o diagnóstico da bacia hidrográfica estudada, que indicou a importância do potencial hídrico subterrâneo no seu curso inferior, sugerindo que fosse dada maior ênfase a um equacionamento das estratégias que servirá de apoio ao início de um gerenciamento deste potencial que se explorado adequadamente poderá dar sustentabilidade à bacia hidrográfica no futuro. Não houve a intenção de propor modelo definido e acabado, principalmente devido à falta de dados e de alguns estudos específicos, mas apresentar os fundamentos e estratégias para o órgão gestor dos recursos hídricos, que poderá ser posto em prática, enquanto estejam sendo desenvolvidos os estudos necessários para a formulação de um modelo consubstanciado.

O diagnóstico da bacia indicou que noventa por cento da área é coberta por sedimentos de idade tércio-quaternária, representados pelos sedimentos do Grupo Barreiras, (Formação Guararapes), que estão recobertos pelas areias de paleodunas, aluviões e paleocascalheiras. Sotoposto a esta formação ocorrem sedimentos cretáceos, constituídos pelos arenitos carbonáticos e calcários. O embasamento cristalino aflora no extremo oeste da área. 
Os estratos arenosos inferiores do Grupo Barreiras constituem efetivamente a unidade geológica aqüifera, encontrando-se limitada na sua parte superior por sedimentos heterogêneos, formados dominantemente de argilas arenosas e arenitos argilosos.

Existe uma freqüente mudança lateral de fácies e passagens bruscas de argilas para arenitos pouco ou não argilosos, facilitando a conexão hidráulica entre as camadas. $\mathrm{Na}$ parte inferior, o sistema aquífero está limitado por arenitos carbonáticos. Os perfis dos poços cadastrados indicam que o aqüifero Barreiras apresenta maiores espessuras saturadas no curso inferior da bacia, com média de 38,0 metros. À montante esta unidade aqǘifera torna-se inexpressiva, os sedimentos restringem-se a uma cobertura constituída por material arenoso de textura variada com espessuras médias de 14 metros sobrepostas ao embasamento cristalino

O uso e ocupação do solo no domínio da bacia tem influenciado significativamente na modificação de suas características naturais com influência no regime dos escoamentos e na qualidade de suas águas. As atividades urbanas e industriais constituem fontes potenciais de contaminação das águas subterrâneas no curso inferior da Bacia, notadamente devido a ausência de rede de esgotos e devido o uso de sistemas de saneamento com disposição local de efluentes (fossas e sumidouros). Convém destacar ainda, uma lagoa de estabilização nas imediações do pólo industrial, de elevado risco potencial de contaminação. Isto ficou caracterizado devido à vulnerabilidade do sistema aqüífero Dunas/Barreiras, no setor leste, que se comporta como um sistema livre coberto por um capeamento dunar, cuja estrutura propicia elevadas taxas de infiltração das águas pluviais. Ressalta-se, portanto, a necessidade da adoção de medidas disciplinadoras para o uso e ocupação do solo.

Os cursos superior e médio da bacia apresentam expressiva vocação agrícola, para o desenvolvimento da cana de açúcar, fruticulturas, hortigranjeiras e culturas de subsistência.

O potencial hídrico da Bacia do Rio Doce é utilizado atualmente para fins de abastecimento público, industrial, irrigação, animal e atividades de lazer. As condições de explotação são efetuadas através do bombeamento de poços tubulares, cacimbões e da lagoa de Extremoz. Entre os 275 pontos de captação de água subterrânea cadastrados, 188 são poços tubulares e 87 são cacimbões, de forma que $76 \%$ dessas estruturas hídricas são utilizados restritamente para uso humano, $15 \%$ para o uso industrial e $9 \%$ para irrigação.

No que se refere ao perfil dos usuários dos poços tubulares, $60 \%$ são particulares, $24 \%$ são gerenciados pelos serviços de abastecimento público e $16 \%$ pelas indústrias. 
A forma da distribuição espacial a nivel de bacia hidrográfica dos pontos d'água cadastrados, apresenta-se indicando uma forte relação com as características hidrogeológicas e sócio-econômicas da região. De modo que, à montante da bacia, onde predominam as rochas do embasamento cristalino, a quantidade de poços é significativamente inferior, havendo uma maior predominância de cacimbões com uso especificamente para consumo humano.

No curso inferior da bacia, devido a existência dos corpos de água superficiais (rios e lagoas) e do expressivo potencial do aqüífero Barreiras os projetos das obras de captação e dos usos da água são mais diversificados, incluindo cacimbões e poços tubulares com diâmetros de revestimento que variam de 4,0 a 8,0 polegadas e vazões de $5 \mathrm{~m}^{3} / \mathrm{h}$ a 150 $\mathrm{m}^{3} / \mathrm{h}$.

A potenciometria do sistema aqüifero Dunas/Barreiras no curso inferior da bacia indicou duas frentes de fluxo, uma ao norte da área, com fluxo convergente para o rio do Mudo, lagoa de Extremoz e rio Doce, com gradientes da ordem de 0,97\% e uma frente ao sul da área com fluxo direcionado para o rio Guajiru, lagoa de Extremoz e rio Doce, com gradientes de $0,8 \%$.

A descarga estimada para o setor norte foi de $42,0 \times 10^{6} \mathrm{~m}^{3} /$ ano e para o setor sul, foi da ordem de $34,0 \times 10^{6} \mathrm{~m}^{3} / a$ no. A vazão total do fluxo subterrâneo natural ficou estimada em $76,0 \times 10^{6} \mathrm{~m}^{3} /$ ano. As reservas permanentes foram estimadas em $354 \times 10^{6} \mathrm{~m}^{3}$.

$O$ consumo atual de águas na Bacia do Rio Doce é da ordem de $42,9 \times 10^{6} \mathrm{~m}^{3} /$ ano, sendo que $21,3 \times 10^{6} \mathrm{~m}^{3} / \mathrm{ano},(50 \%)$, é proveniente das águas subterrâneas do sistema aqüífero Dunas/Barreiras, equivalente a $28 \%$ das reservas reguladoras.

A demanda total estimada para o ano 2010 , indicou uma cifra da ordem de $59,4 \mathrm{x}$ $10^{6} \mathrm{~m}^{3} /$ ano. Diante desta perspectiva a demanda de água subterrânea, (sistema aqǘfero Dunas/Barreiras), poderá variar em função da tomada de decisão da CAERN, em relação a exploração ou não da vazão total prevista no projeto de adução da lagoa de Extremoz que é de $1000 \mathrm{~L} / \mathrm{s}$, cujo volume explorado atualmente é de $634 \mathrm{~L} / \mathrm{s}$. No caso da exploração de uma vazão de $1000 \mathrm{~L} / \mathrm{s}$ a demanda de água subterrânea, (sistema aqüífero Dunas/Barreiras), foi estimada em $29 \times 10^{6} \mathrm{~m}^{3} /$ ano, equivalente a $38 \%$ das reservas reguladoras. Entretanto, caso seja mantida a vazão de exploração atual da lagoa, $(634 \mathrm{~L} / \mathrm{s})$, a estimativa da demanda de água subterrânea indicou um volume da ordem de $37,8 \times 10^{6} \mathrm{~m}^{3} / a$ no, correspondente a $49,7 \%$ das reservas reguladoras.

O diagnóstico da qualidade química das águas superficiais da bacia, indicou que ocorre uma diminuição da salinidade no sentido dos escoamentos, provavelmente, devido a 
maior contribuição das águas subterrâneas do sistema aqüífero Dunas/Barreiras, como também a forte influência da geologia local. Ou seja: em direção à montante da bacia onde ocorrem rochas do embasamento cristalino, as águas superficiais apresentam maiores concentrações de sólidos totais dissolvidos, com teores de $1000 \mathrm{mg} / \mathrm{L}$, enquanto que no curso inferior, onde predominam os sedimentos do Grupo Barreiras, essas concentrações compreenderam uma faixa de valores entre 200 a $500 \mathrm{mg} / \mathrm{L}$.

Em relação às águas subterrâneas, foi verificado que no curso médio da bacia os teores de sólidos totais dissolvidos apresentaram-se na faixa de 300 a $450 \mathrm{mg} / \mathrm{L}$, atingindo valores superiores a $450 \mathrm{mg} / \mathrm{L}$, em direção à montante. No curso inferior, da bacia, as concentrações dos sólidos totais dissolvidos, compreenderam um intervalo de 50 a $250 \mathrm{mg} / \mathrm{L}$. No entanto, a excelente qualidade das águas subterrâneas, favorecida pelas condições climáticas e hidrogeológicas locais, está submetida aos efeitos impactantes da falta de uma estrutura adequada que acompanhe o desenvolvimento urbano e industrial no curso inferior da Bacia do Rio Doce. Essa situação se reflete nos teores de nitrato que crescem a partir de um nivel geral de base de $10 \mathrm{mg} / \mathrm{L}$, em direção aos conjuntos habitacionais da zona norte de Natal.

Diante desse quadro, o estudo indicou as seguintes sugestões para um melhor gerenciamento dos recursos hídricos no curso inferior da bacia:

- Instalar poços de monitoramento em áreas criteriosamente selecionadas, que possam fornecer dados precisos sobre a variação sazonal dos níveis potenciométricos;

- É de fundamental importância a implantação de um sistema de saneamento com rede de esgotos sanitários, principalmente no parque industrial, nas áreas urbanizadas e naquelas que encontram-se em expansão urbana situadas sobre os sedimentos dunares.

- Preservar as dunas como forma de garantir elevadas taxas de infiltração de águas subterrâneas;

- Preservar a região norte da área estudada, contígua à margem direita do Rio Doce e Lagoa de Extremoz, identificada como região produtora;

Do ponto de vista do gerenciamento integrado dos recursos hídricos na bacia estudada, foram diagnosticadas duas situações, uma de escassez de água, que ocorre a montante da bacia decorrente dos aspectos quantitativos e outra de abundância de água no curso inferior, que está submetida aos efeitos impactantes do desenvolvimento industrial e urbano aliados a falta de saneamento.

Constatou-se também que a componente escassez poderá ser solucionada, contemplando as águas subterrâneas do Sistema Aqüífero Dunas/Barreiras que ocorrem no 
curso inferior da bacia através de transposição das águas. Neste sentido, concluiu-se que a prioridade maior é a de gerenciar as águas subterrâneas no curso inferior da bacia, principalmente sob o aspecto qualitativo. Dentro deste contexto, o estudo apontou estratégias para um gerenciamento efetivo destes recursos, tendo como base a outorga do direito de uso da água, as licenças de obras hídricas, a criação da associação dos usuários das águas e de um comitê de bacia. No entanto, para que esta base tenha sustentação, sugere-se que o órgão gestor tenha uma equipe técnica capacitada, perante o conhecimento e o tratamento dos problemas da bacia. Para isto recomenda-se a execução de estudos especificos, que trate das áreas de proteção de poços, as APPs, do comportamento da cunha salina, da evolução do ion nitrato nas águas subterrâneas e da tarifação da água.

A cobrança pelo uso da água, incluindo os lançamentos de poluentes, é considerada como uma das alternativas de gerar recursos financeiros para viabilizar a implantação das soluções técnicas e gerenciais, de promover a racionalização do uso da água e de contribuir para a equidade social. No entanto, análises realizadas por LANNA (1997), mostra que este tipo de alternativa gera dúvidas no sentido de que se os custos destes programas de poluição estão de acordo com o poder aquisitivo da sociedade por um ambiente menos degradado. Neste sentido, recomenda-se que sejam realizados estudos para analisar as alternativas de cobrança pelo uso da água e da avaliação de seus impactos nos segmentos afetados.

Finalmente, recomenda-se que este conjunto de informações aliado ao arcabouço jurídico e institucional, seja apoiado com a implementação da denominada análise de recursos hídricos, que são métodos de planejamento quantitativo com múltiplos objetivos. $\mathrm{O}$ mais recente método introduzido, trata-se do Sistema de Suporte a Decisão (SSD). Esta ferramenta sistematiza o processo de planejamento com elementos quantitativos, destacando-se as técnicas de otimização e simulação, procurando estabelecer um alto grau de interação entre o computador e o homem, permitindo ao usuário (decisor) manter controle direto sobre as atividades computacionais e seus resultados, (BRAGA et al. 1998). 


\section{1 - BIBLIOGRAFIA}

ACQUA-PLAN. (1988). Avaliações das possibilidades de infiltração de efluentes domésticos no aqüifero Dunas na área de $\mathrm{Natal}_{2} \mathrm{RN}$. Estudos, Projetos e consultoria, Recife, PE.

ALLERT, M.; BENNET, T.; LEHR, J. H.; PETTY, R. J. (1987). Drastic: a standardized system for evaluating groundwater pollution potential using hydrogeologic setting. USEPA Report 600/2 $-85 / 018$.

ARAÚJO, M. F. F. (1997). Variação anual da comunidade fitoplanctônica da clorofila e da produtividade primária na lagoa de Extremoz - RN. Dissertação de Mestrado. Centro de Biociências, Universidade Federal do Rio Grande do Norte. Natal - RN.

AROUCA, (1988). Reforma Sanitária Brasileira. Tema Radis, 11:2-4.

BARTH, F. \& POMPEU, C. (1987). Modelos para gerenciamento de recursos hídricos. Capítulo 1 - Fundamentos para gestão de recursos hídricos. São Paulo: Nobel: ABRH. (Coleção ABRH de recursos hídricos).

BRAGA, B.; BARBOSA, P.; NAKAYAMA, P. (1998). Sistemas de suporte à decisão em recursos hídricos. ABRH - Revista brasileira de Recursos Hídricos volume 3 n. $3 \mathrm{jul} / \mathrm{set}$ $1998,73-95$.

BRANCO, S.; M. (1986). Hidrologia aplicada à engenharia sanitária. São Paulo: CETESB/ascetesb, 3ed. 640p.

BRANCO, S.; PORTO, R.; CLEARY, R.; COIMBRA, R.; EIGER, S.; LUCA, S.; NOGUEIRA, V.; PORTO, M. (1991). Hidrologia Ambiental - Coleção ABRH de Recursos Hidricos V. 3 p. $3-25$.

BRASIL (1986). $8^{a}$ Conferência Nacional de Saúde. Brasília - Anais $8^{a}$ CNS. Centro de Documentação do Ministério da Saúde, p. 381 - 389. 
BRASIL (1990). Lei $n^{\circ} 8.080$, de 19 de setembro. DOU, 20-09-90. Brasília-DF. Ano CXXVIII, no 182, seção 1.p - 18.055-18.059.

BREMNER, J.; McCARTY, G.; GIANELLO, C. (1986). Reduction of nitrate pollution of groundwater by nitrogen fertilizers. AGRI. IMPACT. ON GROUNDWATER CONFERENCE. Proceed NWWA. 467-181PP.

BRICAUD, A. \& SATHYENDRANATH, S. (1981). Spectral signatures of substances responsible for the change in ocean color. In: signature spectrales d' objects en télédetection, Avignon 8-11.

CAMPOS e SILVA, A. (1969). Contribuicão ao Estudo do Grupo Barreiras no Rio Grande do Norte. Univ. Fed. do Rio Grande do Norte, Inst. Antropol, Natal, 14p.

CAMPOS e SULVA, A. \& COUTINHO, P.M. (1971). Aspectos sedimentológicos da formação Macaiba na região de Natal/RN. Estudos Sedimentológicos., 2:133-143

CASTANY, G. (1975). Prospeccnión y explotación de las águas subterrâneas. Ediciones Omega, S.A., Barcelona, Spain, 738 p.

CASTRO, V. L. L.; VAREllA NETO, P. L.; BARROSO, T. T. (1988). Avaliação dos Poços da Indústria Guararapes Têxtil, Extremoz-RN. Companhia de Desenvolvimento de Recursos Minerais do Rio Grande do Norte (CDM/RN).

CASTRO, V. L. L. (1994), Origem e Mecanismo de Poluição das Águas Subterrâneas na Área de Cidade Nova - Natal/RN. Dissertação de Mestrado, UFPE - Centro de Tecnologia, pós-graduação em Geociências;

CASTRO, V. L. L. (2000). Diagnóstico da Bacia do Rio Doce-RN: Subsídio para um Modelo de Gestão Integrada dos seus Recursos Hidricos. I Congresso sobre Aproveitamentos e Gestão de Recursos Hídricos em Países de Idioma Português. Anais, 17 a 20 de abril, Rio de Janeiro-RJ. 
CASTRO, V. L. L. (2000). Desenvolvimento urbano e industrial no curso inferior da Bacia do Rio Doce e os efeitos impactantes no sistema aqüifero-lacustre Extremoz-RN: Análise Preliminar. I Congresso Mundial Integrado de Águas Subterrâneas. Anais, 31 de julho a 4 de agosto, Fortaleza-CE.

CÉCILLON, Y. (1996). Doenças de veiculação no meio hídrico. XI Seminário - Curso Salvador -BA, 23 a 26 de outubro/96 - Centro Interamericano de Recursos da Água CIRA

CLEARY, T. (1992). Investigação de modelos matemáticos em microcomputadores dos efeitos dos principais parâmetros hidrogeológicos e dos processos atenuantes de transporte na delineação de áreas de proteção de poços (APPS) e na remediação de aqüiferos contaminados. (Dissertação de Mestrado IGUSP, inédita).

COHEN, S.; CREEGER, S.; CARSEL, R.; ENFIELD, C (1984). Potential for pesticide contamination of groundwater resulting from agricultural uses. American Chemical Soc. Symp. Serie. $N^{\circ} 259$. Waschington, $27 \mathrm{pp}$.

COMISSÃO NACIONAL DA REFORMA SANITÁRIA (CNS) (1987). Documentos UI. Rio de janeiro, p. $7-26$.

COMPANHIA DE ÁGUAS E ESGOTOS DO RIO GRANDE DO NORTE (CAERN) (1977). Projeto de captação de água da Lagoa de Extremoz.

COMPANHIA DE ÁGUAS E ESGOTOS DO RIO GRANDE DO NORTE (CAERN) (1995). Avaliação dos riscos de contaminação e proteção das águas subterrâneas de Natal. Companhia de Águas e Esgotos do Rio Grande do Norte. Natal.

COMPANHIA DE ÁGUAS E ESGOTOS DO RIO GRANDE DO NORTE (CAERN) (1996). Registros dos dados de efluentes industriais. Escritório de Extremoz/RN.

COMPANHIA DE PESQUISA E RECURSOS MINERAIS (CPRM) (1996). A água em revista. Revista Técnica e Informativa. Suplemento das águas, maio/96. 
COMPANHIA DE TECNOLOGIA DE SANEAMENTO AMBIENTAL (CETESB) (1982). Avaliação das condições limnológicas nas lagoas de Extremoz e Jiqui, Natal/RN. São Paulo.

CONSTITUIÇÃO (1988). República Federativa do Brasil. P. 133 - 138.

CONSULTORIA TÉCNICA DE GEOLOGIA E ENGENHARIA (CONTEGE) (1970). Estudo hidrogeológico de Natal-RN. Definicão da potencialidade dos recursos hídricos do sistema Dunas-Barreiras e condições de exploração até o ano 2000.

COSTA, W. D. (1970). Estudo hidrogeológico de Natal/RN. Consultoria Técnica de Geologia e Engenharia, Companhia de Água e Esgotos do Rio Grande do Norte. Recife, PE;

COSTA, W. D. \& SALIM, J. (1972). Aspectos estruturais da faixa sedimentar costeira da região de Natal/RN. Estudos Sedimentológicos, 2: 133-143.

COSTA - CONSULTORIA E SERVIÇOS TÉCNICOS E AMBIENTAIS LTDA. (1997) Estudo da disponibilidade hídrica da Lagoa do Bonfim no município de Nísia Floresta -: RN: Natal/RN, SERHID/COSTA - Consultoria e Serviços Técnicos e Ambientais Ltda. $83 p$.

CRUZ, E. F. (1983) Geologia do Litoral Oriental Potiguar - Área de Taipu/RN. Natal/RN. 257p. (Relatório de Graduação) - Departamento de Geologia/UFRN.

CUSTÓDIO, E. \& LLAMAS, M. R. (1976). Hidrologia Subterrânea. Barcelona, Ed. Omega. 2v, il.

DINIZ FILHO, J. B. (1993). Uma análise geoestatística da distribuicão de clásticos permeáveis em depósitos aluviais do Rio Grande do Norte. Recife, 80 p. (Dissertação de Mestrado), Centro de Tecnologia - UFPE. 
DINIZ FLLHO, J. B. (1999). Recursos Hídricos Subterrâneos no Médio e Baixo Curso da Bacia Hidrográfica do Rio Ceará Mirim/RN. Instituto de Geociências, USP - Tese de Doutoramento, $177 \mathrm{p}$.

DOMENICO, P. A; SCHWARTZ, F. W. (1990). Physical and Chemical Hydrogeology. Canada, 824p.

DUARTE, M. A. (1999). Utilização dos Índices do Estado Trófico (EIT) e de Qualidade da Água(IQA) na caracterização limnológica e sanitária das Lagoas de Bonfim. Extremoz e Jiqui (RN). Centro de Ciências e Tecnologia - Universidade Federal da Paraiba, UFPB, Dissertação de Mestrado $148 \mathrm{p}$.

FENZL, N. (1988). Introdução à hidrogeoquímica $189 \mathrm{p}$.

FIGUEIREDO, A. (1977). Projeto de Captação D’água da Lagoa de Extremoz, memória descritiva.

FIGUEREDO, E. M.; MARTINS, C. A.; CASTRO, V. L. L. (1992). Abastecimento de Água Potável na Base Naval Ary Parreiras, Natal, RN. Companhia de Desenvolvimento de Recursos Minerais do Estado do Rio Grande do Norte (CDM/RN).

FIGUEIREDO, F. G. (1997). Metais Pesados em Sedimentos Superficiais do Estuário Potengi-RN. Dissertação de Mestrado. UFRN - Centro de Ciências Exatas, Departamento de Engenharia Química.

FOSTER, S. \& HIRATA, R. (1991). Determinacion del Riesgo de Contaminacion de Águas Subterráneas. Una metodologia basada em datos existentes. CEPIS - Technical Report (OPS-OMS- HPE, CEPIS, Lima Perú), 81 p. il.

FREEZE, R. A \& CHERRY, J. A. (1979). Groundwater. Prentice-Hall, Englewood Chiffs, New Jersey, USA. $601 \mathrm{p}$.

FUNDAÇÃO NACIONAL DE SAÚDE (1996). Setor de Epidemiologia. Relatório Interno. 
GARCIAS, C. M \& NUCCI, R. N. L. (1993). Indicadores de qualidade dos serviços e infraestrutura urbana de saneamento. Anais do $17^{\circ}$ Congresso Brasileiro de Engenharia Sanitária e Ambiental, Vol. 2, Tomo III, p. $713-734$.

GUAZZELLI, M. R. \& OTTA, N. (1979). Rede de amostragem e indicadores de qualidade de água: critérios e conceituações. Congresso Brasileiro de Engenharia Sanitária e Ambiental. Anais ABES. Manaus - AM.

HEM, J. D. (1985). Study and Interpretation of the chemical characteristics of Natural Water. US Geological Survey Water-supply Paper no. $2254,3^{\text {rd }}$ ed.

HIRATA, R. (1994). Fundamentos e Estratégias de Proteção e Controle da Qualidade das Águas Subterrâneas. Estudo de casos no Estado de São Paulo. Tese de Doutoramento IGUSP, inédita.

HUBBARD, R.; ASMUSSEN, L; ALLISON, H. (1984). Shallow groundwater quality beneth na intensive multiple-cropping system using center pivot irrigation; Jour. Environm Quality, 13(1):156-161.

INSTITUTO BRASILEIRO DE GEOGRAFIA E ESTATÍSTICA (IBGE) (1996). Pesquisa Nacional por Amostra de Domicilios -- PNAD'S.

INSTITUTO BRASILEIRO DE GEOGRAFIA E ESTATISTTICA (IBGE) (1996). Contagem Populacional

INSTITUTO DE DESENVOLVIMENTO ECONÔMICO E MEIO AMBIENTE (IDEC/RN) (1998). Legislação Ambiental do Rio Grande do Norte. $190 \mathrm{p}$.

INSTITUTO DE DESENVOLVIMENTO ECONÔMICO E MEIO AMBIENTE (IDEMA/RN), (1999). Perfil Sócio-Econômico e Demográfico do Rio Grande do Norte.

INSTITUTO NACIONAL DE METEOROLOGIA - INMET (1992). Normas climatológicas (1961 - 1990), Brasília. 50p. 
INSTITUTO DE PESQUISAS TECNOLÓGICAS DO ESTADO DE SÃO PAULO (IPT) (1981). Reconhecimento Hidrogeológico e Estudo Sobre a Qualidade Atual das Águas Subterrâneas da Grande Natal, São Paulo. V 2 (Relatório no 14.813).

INSTITUTO DE PESQUISAS TECNOLÓGICAS DO ESTADO DE SÃO PAULO (IPT) (1982). Estudo Hidrogeológico Regional Detalhado do Estado do Rio Grande do Norte, São Paulo. Vol. 1371 p.

JARDIM DE SÁ, E. F. (1984). Geologia da Região do Seridó. Reavaliação de Dados. In: Simpósio de Geologia do Nordeste, 11, Natal, 1990. Anais. Natal, p. 278-296.

KOMOR, S. C \& ANDERSON, Jr. H. W. (1993). Nitrogen isotopes as indicators of nitrat sources in Minnesota sand plain aquifers. Ground Water, 31(2):260-270.

LANNA, E. (1997). Texto de referência do curso introducão à gestão dos recursos hidricos, $225 \mathrm{pp}$.

LEAVEL, H. \& ClARK, E. G. (1976). Medicina Preventiva . São Paulo, Megraw-Hill, $744 p$

LEWIS, W. J.; FOSTER, S.; DRASAR, B. S. (1988). Analisis de contaminacion de las águas subterráneas por sistemas de saneamiento basico. CEPIS Techinical Report (OPSOMS-HPE,CEPIS, Lima, Peru).

LÓPEZ, R. A. E. (1998). Análise da epidemia da cólera no Peru, 1991-1993. São Paulo, s.n; 1998. 141 p. Tese apresentada a Universidade de São Paulo. Faculdade de Saúde Pública. Departamento de Epidemiologia para obtenção do grau de Mestre.

MABESOONE, J. M. (1972). Caracterização Sedimentológica do Grupo Paraiba (Nordeste do Brasil). Estudos Sedimentológicos/UFPE. Vol. 2, p. 53-63.

MABESOONE, J.M.; ROLIM, J .L.; CASTRO. C. (1977). Late Cretaceous and Cenozic History of Northeastern, Brasil. Geologie Mijnbouw, 56: 129-139. 
MABESOONE, J. M. (1991a). Estudos Geológicos/UFPE. Série B, vol. 10, p. 10-20

MANOEL FILHO, J. (1970). Inventário Hidrogeológico do Nordeste. Folha $\mathrm{n}^{\circ} 10$ Jaguaribe/NE. Recife/PE, SUDENE. 343p.

MANOEL FLLHO, J; CASTRO, V. L .L.; FIGUEIREDO, E .M. (1994). O meio não saturado e os riscos de poluição das águas subterrâneas na zona leste de Natal-RN. Anais do $8^{\circ}$ Congresso Brasileiro de Águas Subterrâneas

MARTINS, M. T; PELLIZARI, V. H; PACHECO, A; MYAKI, D. M; ADAMS, C; BOSSOLAN, N .R.; MENDES, J. M. B.; HASSUDA, S. (1991). Qualidade Bacteriológica de águas subterrâneas em cemitérios. Rev. Saúde Pública. São Paulo $25(1): 47-52$.

MEIRELES, L. (1990). Direito administrativo Brasileiro, $17^{\text {a }}$ ed. São Paulo.

MELO, J. G. \& FIGUEREDO, E. M. (1990). Comportamento hidráulico e vulnerabilidade do sistema aqüifero Dunas/Barreiras à poluição na área de Natal/RN. Anais Águas Subterrâneas, ABAS, São Paulo, 13: 112-124.

MELO, G. J. (1995). Impactos do Desenvolvimento Urbano nas Águas Subterrâneas de Natal/RN. Instituto de Geociências, USP - Tese de Doutoramento.

MELO, G. J. (1998). Avaliação dos Riscos de contaminação e proteção das águas subterrâneas de Natal - Zona Norte. Natal, RN, Companhia de Águas e Esgotos do Estado do Rio Grande do Norte (CAERN)/UFRN. 190p.

MELO, J. G. \& FETTOSA, E. C. (1998). Pesquisa Hidrogeológica do Complexo Lagunar do Bonfim/RN. Relatório Final. Natal/RN, SERHID/UFRN-FUNPEC.100p.

MENDES, E. V. (1988). O sistema unificado e descentralizado de saúde no atual contexto da reforma sanitária brasileira, In: São Paulo - SP p. 5- 14 
NAÇÕES UNIDAS (1976). The demand for water. Natural Resources - Water Series n ${ }^{\circ} .3$.
New York.

NOGUEIRA, A. M. B. (1981). O cenozóico continental da região de Natal - Dissertação de mestrado, Centro de Tecnologia da Universidade Federal de Pernambuco, Recife. PE, $119 \mathrm{p}$.

NOGUEIRA, V. P. Q. (1991). Qualidade da água em lagos e reservatórios. Hidrologia Ambiental, coleção ABRH, v. 3, p165 - p208.

OLIVEIRA, E.; CLEARY, R. W.; CUNHA, R. C. A.; PACHECO, A. (1990), Gasoline hidrocarbons: groundwater pollution potential in Metropolitan São Paulo. International Seminer of Pollution, Protection and Control of Ground Water, Porto Alegre, RS, p. 92-103.

OLIVEIRA, E. (1998). Aspectos político-institucionais no processo de planejamento e gestão das águas subterrâneas: a experiência da Bacia do Mogi-Pardo em São Paulo. X Congresso Brasileiro de Águas Subterrâneas, Anais, 9 a 11 de setembro de 1998.

OLIVEIRA, F. G. (1994). Autodepuracão e monitoramento do Rio Pitimbu - RN Dissertação de Mestrado- UFRN - Programa de Pós-Graduação em Engenharia Química.

OLIVEIRA, J. A. (1997). Otimização da operação de reservatórios de reservatórios para atividades agrícolas - Bacia do Rio Mundaú - FUNCEME 54p.

O.M.S. (1984). Guias para calidad del agua potable. V.1 Washington D.C.

O.P.S \& O.M.S. (1980), Critérios de salud ambiental 5 - Organizacion Panamericana de la Salud. Organizacion Mundial de la Salud, Washinton, E.U.A. Pulicación Científica $N^{\circ}$. 394

PACHECO, A. (1986). Os cemitérios como risco potencial para as águas de abastecimento. Ver. Sistema de Planejamento. Adm. Metropolitana. P. 17-25. 
PACHECO, A.; MENDES, J. M. B.; HASSUDA, S. (1988). O problema geoambiental da localização de cemitérios em meio urbano. $5^{\circ}$ Cong. Bras. de Águas Subterâneas, São Paulo, SP, Anais: 207-215.

PACHECO, A. \& MENDES, J. M. B. (1990). Cemitérios podem contaminar as águas subterrâneas. Ver. Saneamento ambiental, julho, no. 6, p. 31-33.

PACHECO, A.; MENDES, J.M.B; MARTINS, M.T.; HASSUDA, S.; KIMMELMANN, A (1990). Cemitéries - A potetial risk to ground water. Preprints International Seminar of pollution, protection and control of groundwater, Porto Alegre, RS. P. 85-91.

PACHECO, A.; PELLIZARI, V.H.; MIDORI, D; TORRES, S. \& MENDES, J.M.B. (1992). Os perimetros de proteção sanitária em cemitérios e sua importância para as águas subterrâneas de abastecimento. Escudo preliminar. $7^{\circ}$ Cong. Bras. de Águas Subterrâneas, Belo Horizonte, MG., Anais: 119-122.

PAIM, J. S. (1986). Saúde, crises e reformas - p. 187 a 250.

PAIM, J. S. (1990). Obstáculos não superados na implantacão do SUDS - BA Saúde em debate 28:16-21

PEREIRA, M. G. (1993). Qualidade das águas dos mananciais de superficie utilizados no abastecimento da cidade do Natal: Aplicacão do IQA nos pontos de captação. Dissertação de Mestrado, UFRN, Programa de Pós-Graduação em Engenharia Química.

PLANAT Consultoria em Recursos Naturais, CAERN. (1982). Disponibilidade de recursos hídricos na região de Natal - Água de Superficie.

PLANAT - Consultoria em Recursos Naturais, CAERN (1983). Estudo hidrogeológico da região de metropolitana de Natal. Planejamento em Recursos Naturais, Recife, PE. Companhia de águas e Esgotos do Estado do Rio Grande do Norte (CAERN), Relat. Final, Natal/RN; 
PORTO, R; BRANCO, S.; CLEARY, R; COIMBRA, R.; EIGER, S.; LUCA, S.; NOGUEIRA, V;; PORTO, M. (1991). Hidrologia Ambiental - Coleção ABRH de Recursos Hídricos v. 3 p. $3-25$.

REBOUÇAS, A. C. (1994). Gestão sustentável dos grandes aqüiferos. $8^{\circ}$ Congresso brasileiro de águas subterrâneas, Recife - PE. Anais - Edição: ABAS/DNPM/CPRM, $131-139$.

REBOUÇAS, A. (1996). Inserção da água subterrânea no gerenciamento de recursos hídricos Notas de aula.

REBOUÇAS, A. (1997), Água na região nordeste: desperdicio e escassez. Instituto de Estudos Avançados-USP. 11(29). p. 127-154.

RÊGO, F. (1999). Programa de incentivo à criacão de associações de usuários de água. Experiência do Rio Grande do Norte na gestão participativa das águas superficiais e subterrâneas. Secretaria de Recursos Hídricos do Estado do Rio Grande do Norte SERHID.

RESOLUÇÃO DO CONAMA No 20 (1986). Publicado no D.O.U de 30/julho/86.

ROUQUAYROL, M. (1993). Epidemiologia \& Saúde $4^{a}$ edição. Rio de Janeiro: MEDSI, 540 p.

SALIM, J. \& COUTINHO, P. (1974). Aspectos sedimentológicos do estuário do Potengi; Natal/RN. Rev. Estudos Sedimentológicos;

SANTIAGO, M. M. F. (1984). Mecanismos de salinização em regiões semi-áridas. Estudo dos acudes Pereira de Miranda e Caxitoré no Ceará. Tese de Doutorado. USP. São Paulo.

SANTOS, J. L. (1999). Estudo do crescimento populacional da Zona Norte de Natal para fins da demanda de água para abastecimento público. Monografia do Curso de 
Especialização em Engenharia de Recursos Hídricos. UFRN - Centro de Tecnologia Departamento de Engenharia Civil, 20 p.

SÃO PAULO (1988). Lei Estadual nº. 6.134. São Paulo.

SÃO PAULO (1991). Decreto Lei ñ .322 .955 . São Paulo.

SCHILEYER, R.; MILDE, G.; MILDE, K. (1992). Wellhead protection zones in Germany: delineation, research and management. Jour. of the Inst. of Water and Envornm. Management. 6(3):303-311.

SCHOELER, H. (1962). Les eaux souterraines. Paris, Masson. 642p.

SECRETARIA DA INDÚSTRIA E DO COMÉRCIO DO ESTADO DO RIO GRANDE DO NORTE (1999). Relatório informativo do Parque Industrial de Extremoz.

SECRETARIA DE PLANEJAMENTO (SEPLAN) (1983). Diagnóstico das condicões ambientais da Lagoa do Jiqui. Rel. Final, Fundação Instituto de Desenvolvimento do Rio Grande do Norte (IDEC).

SECRETARIA DE PLANEJAMENTO (SEPLAN) (1985). Bacias Hidrográficas - Vazões estimadas pelo índice pluviométrico. Fundação Instituto de Desenvolvimento do RN;

SECRETARIA DOS RECURSOS HIDRICOS DO RIO GRANDE DO NORTE(SERHID/RN) (1997). Legislação Sobre Recursos Hídricos do Estado do Rio Grande do Norte. Natal - RN. 64p.

SECRETARIA DOS RECURSOS HIDRICOS DO ESTADO DO RIO GRANDE DO NORTE (SERHID/RN) (1997). Manual de outorga do direito de uso da água - $121 \mathrm{pp}$.

SECRETARIA DOS RECURSOS HIDRICOS DO ESTADO DO RIO GRANDE DO NORTE (SERHID/RN) (1998). Plano Estadual de Recursos Hídricos. Caracterização Hidrogeológica dos aqüiferos do Rio Grande do Norte. Natal/RN 78p. 
SECRETARIA DOS RECURSOS HIDRICOS DO ESTADO DO RIO GRANDE DO NORTE (SERHID/RN) (1998 a). Estudos de Base, vol. 1. (HE-1358-R23-0998).

SECRETARIA DOS RECURSOS HÍDRICOS DO ESTADO DO RIO GRANDE DO NORTE (SERHID/RN) (1998b). Relatório Diagnóstico dos Dados e Informações Disponíveis Tomo II e III (9HE-1358-R03-0397/ HE-1358-R03-0397).

SECRETARIA DE SAÚDE PÚBLICA DO ESTADO DO RIO GRANDE DO NORTE (1996). Doenças de Notificacãa Compulsória. Séries Históricas. Natal - RN. 45p.

SECRETARIA DE SAÚdE PÚBLICA DO ESTADO DO RIO GRANDE DO NORTE (1999). Doenças de Notificação Compulsória. Séries Históricas. Natal-RN. 30p.

SOUZA, R. \& MOTA, F. S. (1994). Qualidade e conservação da água com vistas ao desenvolvimento sustentável do semi-árido nordestino. Versão preliminar. Projeto Áridas, SUDENE - Brasília, 58p.

STUMM, W. \& MORGAM, J. J. (1981). Aquatic chemistry, 2nd Edition. Wiley, New York. $780 \mathrm{p}$.

TAHAL - SONDOTÉCNICA (1969). Aproveitamento hidroagrícola das bacias do tio Ceará Mirim e da lagoa de Extremoz. Projeto para o abastecimento da Zona Norte de Natal. Companhia de Águas e Esgotos do Rio Grande do Norte, CAERN.

TCHOBANOGLOUS, G. \& SCHROEDER, E. D. (1987). Water Quality: Characteristics, Modeling and Modification. Addison-Wesley Pub.

TEXEIRA, J. A. (1988). Modelo Conceitual para Uso e Proteção dos Recursos Hidricos da Faixa Costeira Recife - João Pessoa. São Paulo. 254p. Tese de Doutorado. Instituto de Geociências, Universidade de São Paulo.

TOSTES, T. (1998). Potencialidades e consumo de águas subterrâneas no médio e baixo curso da bacia hidrográfica do Rio Ceará Mirim. Dissertação de Mestrado, UFRN Centro de Ciências Exatas. 
VILA NOVA, N. A. \& REICHARDT, K. (1989). Evaporação/Evapotranspiração de um ecossistema e suas relações com o meio ambiente. Engenharia hidrológica, V.2 coleção da ABRH de recursos hídricos; Editora da UFRJ, $145-195 \mathrm{p}$.

VRBA, J. \& ROMIJNE, E. (Ed.) (1986). Impact of agricultural activities on groundwater. IAH Int. Cont. to Hydrogeology. 5:3322p.

WU, J.; XUE, Y.; LIU, P.; WANG, J.; JIANG, Q.; SHI, H. (1993). Sea-Water Intrusion in the coastal area of Laizhou Bay, China: 2. Sea-Water Intrusion Monitoring.

XUE, Y; XIE, C.; WU, J.; LIU, P.; SHI, H. (1991). A study on sea water and the movement of the salt water-fresh interface. Najing University Press, najing. 
ANEXO 01 - Cadastro dos Poços Tubulares e Cacimbões (Tabelas: A-G) 
ANEXO 01 - Tabela A - CADASTRAMENTO DOS PONTOS D'ÁGUA (POCOS TUBULARES)

\begin{tabular}{|c|c|c|c|c|c|c|c|c|c|c|}
\hline ID & $\begin{array}{l}\text { Coorde } \\
\mathrm{x}^{2}\end{array}$ & $\begin{array}{c}\text { enadas } \\
Y \\
\end{array}$ & Localidade & Município & Proprietário & $\begin{array}{c}\mathrm{P} \\
(\mathrm{m})\end{array}$ & $\begin{array}{l}\mathrm{NE} \\
(\mathrm{m})\end{array}$ & $\begin{array}{l}\mathrm{HB} \\
(\mathrm{m}) \\
\end{array}$ & Uso & $\begin{array}{c}\text { Vollano } \\
\left(\mathrm{m}^{3}\right)\end{array}$ \\
\hline P1 & 256,004 & $9.366,775$ & Redinha & Extremoz & Redinha Praia Hotel & & & 0,40 & $\mathrm{H} / \mathrm{D} / \mathrm{L}$ & $1.800,00$ \\
\hline $\mathrm{P2}$ & 255,750 & $9.365,482$ & Hotel Atlântico Norte & Extremoz & Hotel Atlântico Norte & 46,0 & 2,13 & 0,10 & $\mathrm{H} / \mathrm{D} / \mathrm{L}$ & $2.880,00$ \\
\hline P6 & 253,903 & $9.370,567$ & Posto Genipabu & Extremoz & Posto Genipabu & & & & $\mathrm{H} / \mathrm{D}$ & 540,00 \\
\hline$P 7$ & 253,854 & $9.369,896$ & Hotel Genipabu & Extremoz & Hotel & & & 0,66 & $\mathrm{H} / \mathrm{D} / \mathrm{L}$ & $1.800,00$ \\
\hline P10 & 253,511 & $9.371,078$ & Água Mineral S.Reis & Extremoz & Agua Mineral & 75,0 & & 0,50 & IND & $93.600,00$ \\
\hline $\mathrm{P} 12$ & 253,300 & $9.364,600$ & Sítio Gramoré & Natal & & 41,0 & 6,97 & & $\mathrm{H} / \mathrm{D}$ & $2.520,00$ \\
\hline P14 & 252,957 & $9.371,377$ & Fábrica de Tubos & Extremoz & Fábrica de Tubos & 80,0 & & 0,27 & H/D/IND & 720,00 \\
\hline P16 & 252,719 & $9.367,431$ & Rio Doce & Extremoz & Inácio Antonio & 12,0 & 1,75 & 0,23 & $\mathrm{H} / \mathrm{D} / \mathrm{L}$ & $2.880,00$ \\
\hline P17 & 252,627 & $9.367,761$ & Estrada de Genipabu & Extremoz & Manoel Nazareno & & & 0,22 & $\mathrm{H} / \mathrm{D}$ & 162,00 \\
\hline$P 18$ & 252,619 & $9.366,793$ & & Extremoz & Luis Clementino S. & & 4,19 & 0,86 & $\mathrm{H} / \mathrm{D}$ & 240,00 \\
\hline$P 19$ & 252,512 & $9.367,832$ & Granja. São José & Extremoz & Oscar Brito & 12,0 & 4,30 & & H/D & 192,00 \\
\hline P20 & 252,345 & $9.364,579$ & Nova República & Natal & & 55,0 & & 0,48 & $\mathrm{H} / \mathrm{D}$ & 540,00 \\
\hline P21 & 251,970 & $9.364,429$ & Nova República & Natal & Djalma Azevedo & 40,0 & & 0,67 & $H / D$ & 360,00 \\
\hline P22 & 251,886 & $9.375,130$ & Contendas & Extremoz & SAAE & 70,0 & 5,0 & & $\mathrm{AP}$ & $44.297,28$ \\
\hline P23 & 251,456 & $9.368,185$ & Gramoré & Natal & Luiz & & & 0,27 & AP & 156,00 \\
\hline $\mathrm{P} 24$ & 251,166 & $9.366,524$ & Conj. Pajuçara I (P01) & Natal & CAERN & 54,0 & 16,17 & 0,6 & $A P$ & $950.000,00$ \\
\hline$P 25$ & 250,990 & $9.366,690$ & Conj. Gramoré (P06) & Natal & CAERN & 56,65 & 19,45 & 0,5 & AP & $864.000,00$ \\
\hline P26 & 250,883 & $9.366,416$ & Conj. Gramoré (P07) & Natal & CAERN & 66,16 & 33,73 & 0,1 & AP & $691.000,00$ \\
\hline $\mathrm{P} 27$ & 250,856 & $9.366,609$ & Conj. Gramoré (P09) & Natal & CAERN & 56,28 & 13,14 & 0,5 & AP & $864.000,00$ \\
\hline P28 & 250,736 & $9.366,124$ & Conj. Gramoré (P05) & Natal & CAERN & 70,35 & 34,64 & 0,5 & AP & $604.800,00$ \\
\hline P29 & 250,641 & $9.365,803$ & Conj. Gramoré (P03) & Natal & CAERN & 66,5 & 23,21 & 0,5 & AP & $518.400,00$ \\
\hline P30 & 250,632 & $9.366,574$ & Conj. Gramoré (P08) & Natal & CAERN & 64,25 & 28,15 & 0,3 & AP & $691.200,00$ \\
\hline P31 & 250,604 & $9.366,815$ & Conjunto Gramoré (Pł0) & Natal & CAERN & 57,5 & 19,31 & 0,2 & $\mathrm{AP}$ & $691.200,00$ \\
\hline P32 & 250,422 & $9.366,287$ & Conjunto Gramoré (P02) & Natal & CAERN & 62,45 & 17,36 & 0,7 & AP & $604.800,00$ \\
\hline P33 & 250,352 & $9.372,440$ & Estivas & Ceará Mirim & SAAE & 42,0 & 15,80 & & AP & $92.489,50$ \\
\hline P34 & 250,333 & $9.366,502$ & Conjunto Gramoré (P11) & Natal & CAERN & & & & $\mathrm{AP}$ & $864.000,00$ \\
\hline P35 & 250,302 & $9.366,455$ & Conjunto Gramoré & Natal & & & & & $\mathrm{H} / \mathrm{D}$ & 360,00 \\
\hline P36 & 249,969 & $9.366,008$ & Conjunto Gramoré & Natal & Centro ldosos & 54,0 & 23,39 & 0,37 & $\mathrm{H} / \mathrm{D}$ & 360,00 \\
\hline
\end{tabular}




\section{ANEXO 01 - Tabela B - CADASTRAMENTO DOS PONTOS D'ÁGUA (POCOS TUBULARES)}

\begin{tabular}{|c|c|c|c|c|c|c|c|c|c|c|}
\hline ID & $\begin{array}{l}\text { Coorde } \\
\times \\
\end{array}$ & $\begin{array}{c}\text { enadas } \\
Y \\
\end{array}$ & Localidade & Município & Proprietário & $\begin{array}{c}\mathrm{P} \\
(\mathrm{m}) \\
\end{array}$ & $\begin{array}{l}\mathrm{NE} \\
(\mathrm{m}) \\
\end{array}$ & $\begin{array}{l}\mathrm{HB} \\
(\mathrm{m})\end{array}$ & Uso & $\begin{array}{c}\text { Volfano } \\
\left(\mathrm{m}^{3}\right)\end{array}$ \\
\hline P38 & 248,909 & $9.373,121$ & Estivas & Extremoz & Valmir Francisco P. & 15,0 & 6,88 & 0,28 & $H / D$ & 240,00 \\
\hline$P 39$ & 248,893 & $9.365,775$ & Nova Natal & Natal & CAERN & & & 0,45 & AP & $250.000,00$ \\
\hline P40 & 248,855 & $9.367,935$ & Lagoa azul & Extremoz & Edmilson & 22,0 & 1,235 & 0,19 & $H / D$ & 162,00 \\
\hline P41 & 248,700 & $9.368,000$ & Lagoa Azul & Extremoz & & 30,0 & 17,00 & & $H / D$ & 360,00 \\
\hline P42 & 248,597 & $9.368,066$ & Lagoa azul & Extremoz & Carlos A. Araújo & 26,0 & 6,0 & 0,32 & H/D & 720,00 \\
\hline$P 43$ & 248,502 & $9.369,610$ & Granja. Santana & Extremoz & Ivan Melo & & & 0,36 & $\mathrm{H} / \mathrm{D}$ & 360,00 \\
\hline P44 & 248,240 & $9.377,990$ & Capim & Ceará Mirim & SAAE & & & & AP & $75.120,00$ \\
\hline P45 & 248,221 & $9.373,120$ & Estivas & Ceará Mirim & SAAE & & & & $A P$ & $18.326,80$ \\
\hline$P 50$ & 247,427 & $9.369,076$ & Lagoa de Extremoz & Extremoz & Telma & & 0,72 & 0,08 & DES & 0,00 \\
\hline P51 & 247,338 & $9.367,816$ & Distrito Industrial & S. G. Amarante & ANTARTICA & & & & IND & $720.000,00$ \\
\hline P52 & 247,260 & $9.369,050$ & Passagem da Vila & Extremoz & SAAE & 58,0 & 34,41 & 0,34 & $A P$ & $71.004,00$ \\
\hline P53 & 247,218 & $9.364,264$ & Distrito Industrial & Natal & VICUNHA & 75,0 & & 0,33 & IND & $68.328,00$ \\
\hline P55 & 247,154 & $9.368,810$ & Lagoa de Extremoz & Extremoz & Wagner Simoneti & & 1,75 & 0,49 & $\mathrm{H} / \mathrm{D}$ & 240,00 \\
\hline P56 & 247,148 & $9.363,815$ & Distrito Industrial & Natal & VICUNHA & 81,0 & 23,49 & 0,36 & IND & $42.924,00$ \\
\hline P58 & 247,113 & $9.369,020$ & Lagoa de Extremoz & Extremoz & Welington Simoneti & & 1,07 & & $H / D$ & 360,00 \\
\hline P59 & 247,045 & $9.364,362$ & Distrito Industrial & Natal & VICUNHA & 74,0 & 18,13 & 0,86 & IND & $87.600,00$ \\
\hline P60 & 247,043 & $9.364,250$ & Cemitério Parque & Extremoz & Cemitério Parque & & & 0,0 & $\mathrm{H} / \mathrm{D}$ & 360,00 \\
\hline P61 & 246,982 & $9.364,632$ & Distrito Industrial & Natal & VICUNHA & 43,0 & 14,76 & 0,23 & IND & 0,00 \\
\hline P63 & 246,937 & $9.364,653$ & Distrito Industrial & Natal & VICUNHA & 15,0 & 14,58 & 0,08 & IND & 0,00 \\
\hline P64 & 246,888 & $9.371,189$ & Faz. Bamburral & Extremoz & Sérgio Murilo & & 27,39 & 0,42 & $\mathrm{H} / \mathrm{D} / \mathrm{Irri} / \mathrm{A}$ & $1.800,00$ \\
\hline P65 & 246,772 & $9.370,550$ & Vale do Aço & Extremoz & José ivo Souza & 50,0 & 20,25 & 0,72 & $\mathrm{H} / \mathrm{D}$ & 720,00 \\
\hline P66 & 246,717 & $9.363,864$ & Distrito Industrial & Natal & VICUNHA & & & 0,35 & IND & $42.048,00$ \\
\hline P68 & 246,667 & $9.364,189$ & Distrito Industrial & Natal & VICUNHA & 56,0 & 16,58 & 0,32 & IND & $78.840,00$ \\
\hline$P 69$ & 246,655 & $9.370,917$ & Granja. Jardim & Extremoz & Osvaldo Florêncio & & & 0,0 & H/D/A & $1.080,00$ \\
\hline P70 & 246,630 & $9.365,522$ & Distrito industrial & Natal & Guararapes Têxtil & & & $-0,97$ & IND & $84.099,96$ \\
\hline P71 & 246,592 & $9.368,610$ & Lagoa de Extremoz & Extremoz & Hotel de Extremoz & & & & $\mathrm{H} / \mathrm{D}$ & $1.095,00$ \\
\hline P72 & 246,590 & $9.365,711$ & Distrito Industrial & Natal & Guararapes Têxtil & & 23,88 & $-1,20$ & IND & $152.464,73$ \\
\hline P75 & 246,558 & $9.370,708$ & Granja. N Sra. Nazaré & Extremoz & Maria V. Carvalho & 42,0 & & 0,27 & $H / D$ & 240,00 \\
\hline P76 & 246,539 & $9.365,777$ & Distrito Industrial & Natal & Guararapes Têxtil & & & $-0,74$ & IND & $53.309,09$ \\
\hline P77 & 246,501 & $9.375,650$ & Estivas & Ceará Mirim & SAAE & 71,0 & 36,0 & & AP & $155.592,00$ \\
\hline
\end{tabular}




\begin{tabular}{|c|c|c|c|c|c|c|c|c|c|c|}
\hline ID & $\begin{array}{l}\text { Coorde } \\
\times \\
\end{array}$ & $\begin{array}{c}\text { enadas } \\
Y \\
\end{array}$ & Localidade & Município & Proprietário & $\begin{array}{c}P \\
(\mathrm{~m}) \\
\end{array}$ & $\begin{array}{l}\mathrm{NE} \\
(\mathrm{m}) \\
\end{array}$ & $\begin{array}{l}H B \\
(\mathrm{~m}) \\
\end{array}$ & Uso & $\begin{array}{c}\text { Vollano } \\
\left(\mathrm{m}^{3}\right)\end{array}$ \\
\hline P78 & 246,500 & $9.362,900$ & Olho D'água do Carrilho & S. G. Amarante & & 70,0 & 29,80 & & $\mathrm{H} / \mathrm{D}$ & $1.095,00$ \\
\hline P79 & 246,474 & $9.365,041$ & Distrito Industrial & Natal & TEXTILE S.A & 65,0 & & 0,15 & IND & 540,00 \\
\hline P80 & 246,471 & $9.363,929$ & Distrito Industrial & Natal & VICUNHA & 82,0 & 24,12 & 0,74 & IND & $82.344,00$ \\
\hline P81 & 246,467 & $9.365,280$ & Distrito Industrial & Natal & MASTEX & 80,0 & 30,20 & & DES & 0,00 \\
\hline P82 & 246,443 & $9.365,300$ & Distrito Industrial & Natal & MASTEX & & & & $\mathrm{H} / \mathrm{D} / \mathrm{NND}$ & $302.400,00$ \\
\hline P83 & 246,443 & $9.365,270$ & Distrito Industrial & Natal & MASTEX & & 25,35 & & DES & 0,00 \\
\hline P84 & 246,442 & $9.365,488$ & Distrito Industrial & Natal & Guararapes Têxtil & & & $-0,88$ & IND & $5.851,00$ \\
\hline P87 & 246,430 & $9.365,600$ & Distrito Industrial & Natal & HENFIBRA & 61,0 & 25,75 & & IND & $1.800,00$ \\
\hline P88 & 246,319 & $9.365,484$ & Distrito Industrial & Natal & Guararapes Têxtil & 81,0 & 27,49 & $-1,18$ & IND & $46.368,00$ \\
\hline P89 & 246,301 & $9.369,140$ & Alto de Extremoz & Extremoz & SAAE & & & 0,0 & AP & $92.093,76$ \\
\hline P90 & 246,285 & $9.370,725$ & Granja. Raquel & Extremoz & Rubens Azevedo & & & 0,22 & $H / D$ & 180,00 \\
\hline P91 & 246,277 & $9.367,100$ & Granja. Veneza & Extremoz & Francisco Ribeiro & & 7,61 & 0,20 & $\mathrm{H} / \mathrm{D}$ & 162,00 \\
\hline $\mathrm{Pg} 2$ & 246,265 & $9.365,196$ & Distrito Industrial & Natal & PARMALAT & 80,0 & 22,54 & & DES & 0,00 \\
\hline P93 & 246,253 & $9.368,930$ & Estrela do Mar & Extremoz & SAAE & 74,0 & 31,51 & 0,0 & $A P$ & $103.733,45$ \\
\hline P94 & 246,253 & $9.365,530$ & Distrito Industrial & Natal & Guararapre Têxtil & & & $-0,84$ & IND & $20,000,00$ \\
\hline P95 & 246,249 & $9.365,688$ & Distrito Industrial & Natal & Guararapes Têxtil & 90,0 & & $-0,94$ & IND & $2.700,00$ \\
\hline P96 & 246,242 & $9.365,063$ & Distrito Industrial & Natal & LABORSIL & 100,0 & & $-1,0$ & IND & $3.600,00$ \\
\hline P98 & 246,202 & $9.374,350$ & Vila de Fátima & Extremoz & SAAE & 34,0 & 4,60 & & $A P$ & $142.680,72$ \\
\hline P99 & 246,178 & $9.370,627$ & Faz. Bamburral & Extremoz & José Cleber Fialho & 54,0 & & 0,15 & $\mathrm{H} / \mathrm{D}$ & 420,00 \\
\hline P100 & 246,175 & $9.368,580$ & Estrela do Mar & Extremoz & SAAE & & & 0,31 & AP & $140.124,00$ \\
\hline P101 & 246,151 & $9.365,142$ & Distrito Industrial & Natal & PARMALAT & 82,0 & 27,20 & 0,46 & IND & $268.800,00$ \\
\hline P103 & 246,097 & $9.366,180$ & Distrito Industrial & Natal & COATS & 90,0 & 32,04 & 0,54 & IND & $350.400,00$ \\
\hline P104 & 246,095 & $9.365,465$ & Distrito Industrial & Extremoz & Cid Gonçalves & & & 0,16 & $\mathrm{H} / \mathrm{D}$ & 180,00 \\
\hline P105 & 246,084 & $9.373,369$ & Granja. G. Cardoso & Extremoz & Geraldo Cardoso & 60,0 & & 0,23 & $\mathrm{H} / \mathrm{D}$ & 540,00 \\
\hline P108 & 246,028 & $9.372,786$ & Murici & Extremoz & SAAE & & & 0,22 & AP & $43.800,00$ \\
\hline P109 & 246,012 & $9.365,048$ & Distrito Industrial & Extremoz & $\mathrm{CDI}$ & 86,0 & 33,65 & 0,30 & H/IND & 720,00 \\
\hline P110 & 245,915 & $9.368,460$ & Granja. São Francisco & Extremoz & Silvio Roberto & 60,0 & 21,10 & & $\mathrm{H} / \mathrm{D} / \mathrm{A}$ & $2.160,00$ \\
\hline P111 & 245,720 & $9.369,847$ & Granja. Mangabeiras & Extremoz & Arnaldo B. Furtado & 53,0 & & & $H / D$ & 360,00 \\
\hline P113 & 245,541 & $9.375,650$ & Santa Maria & Extremoz & SAAE & 49,0 & Jorr & & $A P$ & $59.342,64$ \\
\hline P114 & 245,502 & $9.368,619$ & Toca do Miga & Extremoz & Miguel Carrilho & & & 0,0 & $\mathrm{H} / \mathrm{D}$ & $1.080,00$ \\
\hline P115 & 245,469 & $9.369,643$ & Granja. Padre Cícero & Extremoz & Manoel Pinto Filho & 48,0 & & 0,78 & $\mathrm{H} / \mathrm{D}$ & 540,00 \\
\hline
\end{tabular}


ANEXO 01 - Tabela D - CADASTRAMENTO DOS PONTOS D'ÁGUA (POCOS TUBULARES)

\begin{tabular}{|c|c|c|c|c|c|c|c|c|c|c|}
\hline ID & $\begin{array}{l}\text { Coorde } \\
\times \\
\end{array}$ & $\begin{array}{c}\text { nadas } \\
Y \\
\end{array}$ & Localidade & Município & Proprietário & $\begin{array}{c}P \\
(m)\end{array}$ & $\begin{array}{l}\mathrm{NE} \\
(\mathrm{m})\end{array}$ & $\begin{array}{l}\mathrm{HB} \\
(\mathrm{m})\end{array}$ & Uso & $\begin{array}{c}\text { Vol/ano } \\
\left(\mathrm{m}^{3}\right)\end{array}$ \\
\hline $\mathrm{P} 116$ & 245,354 & $9.369,481$ & Eco Diversões & Extremoz & Carlos Romeu Brito & 60,0 & & & H/D/L & 720,00 \\
\hline$P 120$ & 245,230 & $9.369,390$ & Sede & Extremoz & SAAE & 62,0 & 34,50 & & AP & $37.429,20$ \\
\hline $\mathrm{P} 121$ & 245,216 & $9.368,500$ & Vila Socorro & Extremoz & Editson F. de Assis & 30,0 & 14,0 & 0,0 & $\mathrm{H} / \mathrm{D}$ & $1.080,00$ \\
\hline $\mathrm{P} 122$ & 245,135 & $9.368,743$ & Extremoz & Extremoz & Maria Lúcia Costa & & 34,92 & & DES & 0,00 \\
\hline $\mathrm{P} 123$ & 244,910 & $9.369,700$ & Malvinas & Extremoz & Manoel Fernandes & 52,0 & & 0,80 & $H / D$ & 324,00 \\
\hline $\mathrm{P} 124$ & 244,654 & $9.369,810$ & Malvinas & Extremoz & SAAE & & & 0,48 & $\mathrm{AP}$ & $13.140,00$ \\
\hline P125 & 244,611 & $9.367,534$ & Granja. Alto do Jordão & Extremoz & Pedro Daniel Soares & & 3,16 & 0,48 & $\mathrm{H} / \mathrm{D}$ & 360,00 \\
\hline$P 127$ & 244,50 & $9.369,000$ & Sede & Extremoz & Atila Jones Nelson & 70,0 & 27,50 & & $H / D$ & $1.095,00$ \\
\hline P128 & 244,481 & $9.368,482$ & Granja. Guará & Extremoz & Guaraci Soares & 46,0 & & 0,36 & $\mathrm{H} / \mathrm{D}$ & 600,00 \\
\hline P129 & 244,469 & $9.368,581$ & Sede & Extremoz & João Silva Neto & 47,0 & & 0,35 & H/D/Irri/A & $10.800,00$ \\
\hline$P 130$ & 244,437 & $9.369,966$ & Malvinas & Extremoz & SAAE & & & & DES & 0,00 \\
\hline$P 131$ & 244,388 & $9.368,612$ & Sede & Extremoz & José Alves Costa & & & 0,08 & H/D/Irri/A & $1.800,00$ \\
\hline $\mathrm{P} 132$ & 244,256 & $9.369,342$ & Granja. Padilha & Extremoz & Paulo costa Padilha & 65,0 & & $-1,20$ & $\mathrm{H} / \mathrm{D} / \mathrm{L}$ & $4.320,00$ \\
\hline $\mathrm{P} 135$ & 244,049 & $9.365,012$ & Fazenda. Jardim & São G.Amarante & Hugo Menezes Taixo & 22,0 & & 0,24 & H/D/A & $2.160,00$ \\
\hline P136 & 243,901 & $9.370,455$ & Granja. Wengrid & Extremoz & Laércio de França & 30,0 & & 0,31 & DES & 0,00 \\
\hline P138 & 243,900 & $9.365,400$ & Guajiru & São G.Amarante & & 85,0 & 37,76 & & $\mathrm{H} / \mathrm{D}$ & $1.900,00$ \\
\hline P140 & 243,857 & $9.370,624$ & Granja. Santa Helena & Extremoz & Manoel Graciliano & & & 0,0 & $\mathrm{H} / \mathrm{D} / \mathrm{Irri}$ & $21.600,00$ \\
\hline$P 144$ & 243,548 & $9.369,357$ & Carão & Extremoz & Arouca & & 31,67 & 0,26 & H/D/Irri & 960,00 \\
\hline$P 145$ & 243,538 & $9.369,982$ & Granja São José & Extremoz & José Oliveira & 95,0 & 18,46 & 0,80 & H/D/Irri & $6.912,00$ \\
\hline $\mathrm{P} 146$ & 243,258 & $9.370,930$ & Viveiro (ranários) & Extremoz & José do N. Brandäo & 75,0 & & 0,30 & H/D/Irri & $10.800,00$ \\
\hline$P 149$ & 243,061 & $9.369,091$ & Granja. Marilia(Carão) & Extremoz & & & & 0,30 & $\mathrm{H} / \mathrm{D}$ & 360,00 \\
\hline$P 150$ & 243,000 & $9.369,000$ & Ponta Grossa & Extremoz & & 70,8 & 31,08 & & $\mathrm{H} / \mathrm{D}$ & 912,50 \\
\hline P152 & 242,940 & $9.363,784$ & Viveiro Flora Lima & S. G. Amarante & Mário Queiroz Lima & & & 0,22 & $\mathrm{H} / \mathrm{IrrI}$ & $92.160,00$ \\
\hline$P 153$ & 242,936 & $9.365,993$ & Granja. Guajiru & S. G. Amarante & Raimundo Osvaldo & 30,0 & 10,23 & 0,40 & $\mathrm{H} / \mathrm{D} / \mathrm{A}$ & 300,00 \\
\hline P155 & 242,593 & $9.363,757$ & Guajiru & S. G. Amarante & Francisco Elpídeo & 58,0 & & 0,55 & $\mathrm{H} / \mathrm{D} / \mathrm{Iri}$ & $60.480,00$ \\
\hline P156 & 242,474 & $9.365,496$ & Granja. São Miguel & S. G. Amarante & Manoel Queiroz & 11,0 & 5,0 & 0,72 & $\mathrm{H} / \mathrm{D}$ & 540,00 \\
\hline P157 & 242,381 & $9.365,949$ & Granja Nova Jerusalém & S. G. Amarante & Fernando Pereira & 85,0 & & 0,39 & $\mathrm{H} / \mathrm{D} / \mathrm{L}$ & 360,00 \\
\hline P159 & 241,939 & $9.368,214$ & Lagoa de Extremoz & Extremoz & \begin{tabular}{|l|} 
Nilson Rocha \\
\end{tabular} & & & 0,0 & $\mathrm{H} / \mathrm{D}$ & 360,00 \\
\hline P160 & 241,801 & $9.369,443$ & Lagoa de Extremoz & Extremoz & Miguel & & & 0,35 & $\mathrm{H} / \mathrm{D}$ & 360,00 \\
\hline P161 & 241,774 & $9.364,221$ & Guajiru & S. G. Amarante & Cícero Paulino & 35,0 & & & $\mathrm{H} / \mathrm{D} / \mathrm{A}$ & 720,00 \\
\hline
\end{tabular}




\begin{tabular}{|c|c|c|c|c|c|c|c|c|c|c|}
\hline ID & $\begin{array}{l}\text { Coorde } \\
\times\end{array}$ & $\begin{array}{c}\text { enadas } \\
Y \\
\end{array}$ & Localidade & Município & Proprietário & $\begin{array}{c}\mathrm{P} \\
(\mathrm{m})\end{array}$ & $\begin{array}{l}\mathrm{NE} \\
(\mathrm{m})\end{array}$ & $\begin{array}{l}\mathrm{HB} \\
(\mathrm{m})\end{array}$ & Uso & $\begin{array}{c}\text { Vollano } \\
\left(\mathrm{m}^{3}\right)\end{array}$ \\
\hline P162 & 241,663 & $9.367,785$ & Fazenda Xingu & Extremoz & Nilson Rocha & 55,0 & 14,0 & 0,0 & $\mathrm{H} / \mathrm{D} / \mathrm{A}$ & 360,00 \\
\hline$P 163$ & 241,453 & $9.368,843$ & Lagoa de Extremoz & Extremoz & SAAE & & & 0,87 & AP & $490.320,00$ \\
\hline $\mathrm{P} 164$ & 241,453 & $9.368,830$ & Lagoa de Extremoz & Extremoz & SAAE & & & 1,03 & AP & $446.556,00$ \\
\hline $\mathrm{P} 165$ & 241,453 & $9.368,820$ & Lagoa de Extremoz & Extremoz & SAAE & 30,0 & jorr. & 0,68 & AP & $288.120,00$ \\
\hline$P 166$ & 241,453 & $9.368,800$ & Lagoa de Extremoz & Extremoz & SAAE & & & 0,96 & $A P$ & $636.876,00$ \\
\hline $\mathrm{P} 167$ & 241,400 & $9.368,843$ & Lagoa de Extremoz & Extremoz & SAAE & 29,0 & jorr. & & $A P$ & $490.320,00$ \\
\hline$P+68$ & 241,314 & $9.368,640$ & Lagoa de Extremoz & Extremoz & SAAE & 30,0 & jorr. & 0,41 & DES & 0,00 \\
\hline P169 & 241,208 & $9.369,648$ & Granja. N. Sra. Neves & Extremoz & Nízio Flávio & & & 0,30 & $\mathrm{H} / \mathrm{D} / \mathrm{A}$ & $1.440,00$ \\
\hline P170 & 240,719 & $9.369,103$ & lpês & Extremoz & Marcelo P. Sales. & & & 0,20 & H/D/A & $4.320,00$ \\
\hline P171 & 240,587 & $9.364,777$ & Fazenda Guaijru & S. G. Amarante & Francisco R. Oliveira & 62,0 & 33,47 & 0,41 & H/D/Iri & 720,00 \\
\hline P174 & 239,999 & $9.368,595$ & Comum & Extremoz & SAAE & 28,0 & 5,50 & 0,35 & AP & $1,440,00$ \\
\hline$P 175$ & 239,881 & $9.365,669$ & Fazenda Xingu & S. G. Amarante & Nilson Rocha & & 29,96 & 0,66 & H/D & 360,00 \\
\hline P176 & 239,755 & $9.367,188$ & Ponta Grossa & Extremoz & Lázaro torres & & 5,725 & 0,28 & $\mathrm{H} / \mathrm{D}$ & $1.800,00$ \\
\hline P177 & 239,706 & $9.368,712$ & Comum & Extremoz & Aldemir & 46,0 & 33,53 & 0,28 & $\mathrm{H} / \mathrm{D}$ & 360,00 \\
\hline P179 & 239,459 & $9.367,299$ & Ponta Grossa & Extremoz & Joâo Clementino & & & 0,20 & $\mathrm{H} / \mathrm{D}$ & 360,00 \\
\hline P182 & 238,669 & $9.374,005$ & Massangana & Ceará Mirim & Júnior Bezerra & & & 0,14 & IND & $7.200,00$ \\
\hline P183 & 238,575 & $9.366,173$ & Maçaranduba & S. G. Amarante & SAAE & & & 0,25 & $A P$ & $13.140,00$ \\
\hline P184 & 238,571 & $9.372,049$ & Massangana & Ceará Mirim & Júnior Bezerra & & & 0,13 & IND & $3.600,00$ \\
\hline P185 & 238,558 & $9.372,760$ & Massangana & Ceará Mirim & Júnior Bezerra & 60,0 & & 0,12 & IND & $7.200,00$ \\
\hline P187 & 238,345 & $9.364,150$ & Maçaranduba & S. G. Amarante & Luis Claudino & & & 0,30 & $\mathrm{H} / \mathrm{D}$ & 180,00 \\
\hline P188 & 238,330 & $9.365,735$ & Maçaranduba & Ceará Mirim & Núcleo de Caridade & & & 0,28 & $A P$ & $25.920,00$ \\
\hline P189 & 238,157 & $9.365,251$ & Granja. Valdemar & S. G. Amarante & Valdemar Dário & & & 0,18 & $\mathrm{H} / \mathrm{D} / \mathrm{A}$ & 720,00 \\
\hline P190 & 238,040 & $9.365,159$ & Maçaranduba & S. G. Amarante & Oliveira & & & 0,05 & $\mathrm{H} / \mathrm{D} / \mathrm{sri}$ & $8.640,00$ \\
\hline P194 & 237,394 & $9.367,648$ & Maçaranduba & Ceará mirim & José Lauro da Silva & 40,0 & 35,86 & & DES & 0,00 \\
\hline P195 & 237,392 & $9.365,436$ & Maçaranduba & S. G. Amarante & SAAE & & & 0,20 & AP & $9.360,00$ \\
\hline P197 & 237,350 & $9.368,554$ & Maçaranduba & Ceará Mirim & Hélio Pignataro & & & 0,05 & H/D & $2.160,00$ \\
\hline P198 & 237,258 & $9.365,720$ & Maçaranduba & S. G. Amarante & Francisco Câmara & 60,0 & 25,0 & 0,17 & $\mathrm{H} / \mathrm{D} / \mathrm{L}$ & 720,00 \\
\hline $\mathrm{P} 199$ & 237,161 & $9.367,642$ & Maçaranduba & Ceará Mirim & SAAE & & & 0,50 & AP & $21.900,00$ \\
\hline P201 & 237,100 & $9.365,450$ & Maçaranduba & S. G. Amarante & & 102,8 & 42,63 & & H/D & $1.825,00$ \\
\hline P202 & 237,052 & $9.365,605$ & Maçaranduba & S. G. Amarante & Mário Queiróz & 100,0 & & 0,0 & H/D/lrri & $2.880,00$ \\
\hline
\end{tabular}


ANEXO 01 - Tabela F - CADASTRAMENTO DOS PONTOS D'ÁGUA (POCOS TUBULARES)

\begin{tabular}{|c|c|c|c|c|c|c|c|c|c|c|}
\hline ID & $\begin{array}{l}\text { Coorde } \\
X\end{array}$ & $\begin{array}{c}\text { enadas } \\
y\end{array}$ & Localidade & Município & Proprietário & $\begin{array}{c}P \\
(m)\end{array}$ & $\begin{array}{l}\mathrm{NE} \\
(\mathrm{m})\end{array}$ & $\begin{array}{l}\mathrm{HB} \\
\text { (m) }\end{array}$ & Uso & $\begin{array}{c}\text { Volfano } \\
\left(\mathrm{m}^{3}\right)\end{array}$ \\
\hline P203 & 237,052 & $9.365,455$ & Maçaranduba & S. G. Amarante & Mário Queiróz & 120,0 & & 0,35 & Irri & $21.600,00$ \\
\hline P204 & 236,850 & $9.365,550$ & Granja. Santa Fé & S. G. Amarante & & 100,0 & 39,25 & & $\mathrm{H} / \mathrm{D}$ & 180,00 \\
\hline P206 & 235,913 & $9.365,030$ & Maçaranduba & S. G. Amaranie & Bernadino & & & 0,16 & $\mathrm{H} / \mathrm{D} / \mathrm{Irri}$ & $6.000,00$ \\
\hline P207 & 235,751 & $9.375,154$ & Granja. Boa Sorte & Ceará Mirim & Assis & & 20,96 & 0,10 & $\mathrm{H} / \mathrm{D}$ & 540,00 \\
\hline P208 & 235,713 & $9.374,914$ & Granja. Nunes & Ceará Mirim & Francisco N Tavares & 60,0 & 20,93 & & H/D/Irri & $3.600,00$ \\
\hline $\mathrm{P209}$ & 235,143 & $9.365,621$ & Faz. Santana & S. G. Amarante & Cristiana V. Melo & 80,0 & & 0,35 & $\mathrm{H} / \mathrm{D} / \mathrm{A}$ & $3.600,00$ \\
\hline P210 & 234,851 & $9.365,247$ & Maçaranduba & S. G. Amarante & Assis Melo & 102,0 & 1,85 & 0,10 & DES & 0,00 \\
\hline P211 & 234,750 & $9.365,100$ & Serrinha de Baixo & S. G. Amarante & & 40,0 & & & DES & 0,00 \\
\hline$P 213$ & 233,625 & $9.363,638$ & Granja. São Pedro & S. G. Amarante & Dr. Pedro Alcântara & 110,0 & & 0,22 & H/D/Irri & $13.500,00$ \\
\hline P214 & 233,501 & $9.365,256$ & Novo Horizonte & S. G. Amarante & João Bosco & 97,0 & & 0,0 & H/D & $2.400,00$ \\
\hline P215 & 233,267 & $9.365,052$ & Faz. Catamboeira & S. G. Amarante & Antonio Martins Meio & & 2,95 & 0,25 & $H / D / A$ & 900,00 \\
\hline$P 216$ & 233,082 & $9.364,556$ & EMPASA & S. G. Amarante & Ezequiel(antigo) & 120,0 & 17,00 & & DES & 0,00 \\
\hline P217 & 231,771 & $9.365,085$ & Granja. Boa Vista & S. G. Amarante & Sebastião Cesário & 120,0 & & 0,10 & H/D & $2.160,00$ \\
\hline P218 & 231,674 & $9.365,803$ & Serrinha de Baixo & S. G. Amaranţe & SAAE & 35,0 & & 0,10 & AP & $8.760,00$ \\
\hline P219 & 231,256 & $9.372,889$ & AGROMAR & Ceará Mirim & AGROMAR & & 1,75 & 0,42 & DES & 0,00 \\
\hline$P 220$ & 231,141 & $9.374,420$ & Sede(Col. Agrícola) & Ceará Mirim & Colégio Agrícola & & & 0,25 & DES & 0,00 \\
\hline P221 & 231,092 & $9.374,534$ & Sede(Col. Agrícola) & Ceará Mirim & Colégio Agrícola & & 46,35 & 0,32 & DES & 0,00 \\
\hline P223 & 230,439 & $9.374,972$ & Serrinha & Ceará Mirim & Manoel Venancio & 84,0 & 24,00 & 0,26 & $\mathrm{H} / \mathrm{D}$ & 432,00 \\
\hline $\mathrm{P} 224$ & 230,425 & $9.374,452$ & Parque Teodoro & Ceará Mirim & Marcelo Passos & & & 0,53 & $\mathrm{H} / \mathrm{D}$ & 900,00 \\
\hline P226 & 230,320 & $9.372,984$ & Faz. Sto. Antônio & Ceará Mirim & Antenor Madruga & 60,0 & & 0,35 & H/D/A & 180,00 \\
\hline P227 & 230,152 & $9.365,031$ & Serrinha & S. G. Amarante & POTICRET & 131,0 & 39,56 & 0,36 & H/D/AND & $7.200,00$ \\
\hline P228 & 230,000 & $9.365,177$ & Granja. Juvenal & S. G. Amarante & Juvenal Macedo & & & 0,45 & $\mathrm{H} / \mathrm{D}$ & 180,00 \\
\hline P230 & 229,745 & $9.372,956$ & Granja. Herculano & Ceará Mirim & Luiz Herculano & & & 0,50 & DES & 0,00 \\
\hline$P 231$ & 229,058 & $9.373,265$ & Jacoca(AGROMAR) & Ceará Mirim & Elmo Júnior & & 0,35 & 0,30 & H/D/Irri & $1.080,00$ \\
\hline$P 232$ & 229,058 & $9.364,469$ & Serrinha & S. G. Amarante & SAAE & & & 0,33 & AP & $5.400,00$ \\
\hline P233 & 228,941 & $9.364,542$ & Serrinha & S. G. Amarante & SAAE & & & 0,37 & AP & $5.400,00$ \\
\hline$P 235$ & 228,659 & $9.363,866$ & Serrinha & S. G. Amarante & Gerónimo & & & & $\mathrm{H} / \mathrm{D} / \mathrm{A}$ & 360,00 \\
\hline P236 & 228,629 & $9.375,785$ & Terra da Santa & Ceará Mirim & SAAE & & 38,77 & 0,35 & AP & $5.475,00$ \\
\hline P238 & 228,456 & $9.373,776$ & Faz. Nova llusão & Ceará Mirim & Magnus Barreto & & 5,85 & 0,40 & $\mathrm{H} / \mathrm{D} / \mathrm{A}$ & $1.080,00$ \\
\hline P239 & 228,364 & $9.373,336$ & Jacoca de Cima & Ceará Mirim & Comunidade & 63,0 & & 0,20 & $A P$ & $14.600,00$ \\
\hline
\end{tabular}


ANEXO 01 - Tabela G - CADASTRAMENTO DOS PONTOS D'ÁGUA (POCOS TUBULARES)

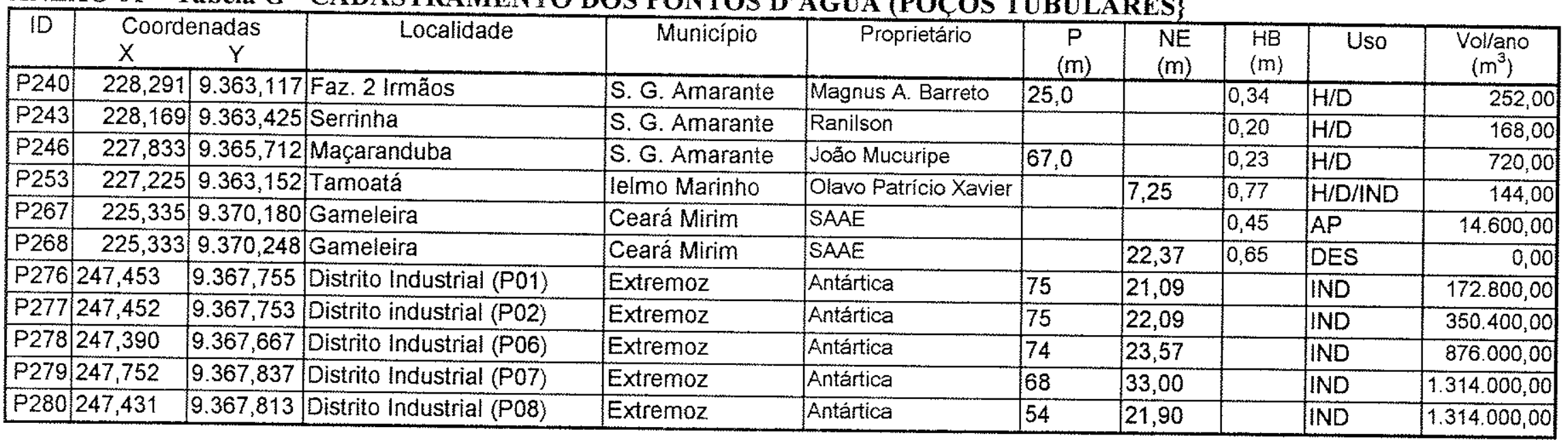

\section{LEGENDA}

$\begin{array}{ll}\text { ID } & \text { Identificação do Ponto Cadastrado } \\ \mathrm{P} & \text { Profundidade (m) } \\ \text { NE } & \text { Nivel Estático }(\mathrm{m}) \\ \text { H/IND } & \text { Humano/lndustrial } \\ \text { ANI } & \text { Animal } \\ \text { H/D } & \text { Humano/Doméstico } \\ \text { H/D/A } & \text { Humano/Doméstico/Animal } \\ \text { H/D/IR/A } & \text { Humano/Doméstico/Irigação/Animal } \\ \text { H/D/L } & \text { Humano/Doméstico/Lazer } \\ \text { H/D/R } & \text { Humano/Doméstico/Irrigação } \\ \text { H/D/IND } & \text { Humano/Doméstico/Industrial } \\ \text { AP } & \text { Abastecimento Público } \\ \text { IND } & \text { Industrial } \\ \text { DES } & \text { Desativado }\end{array}$


Anexo 01 - Tabela A - CADASTRAMENTO DOS PONTOS D'ÁGUA (CACIMBÕES)

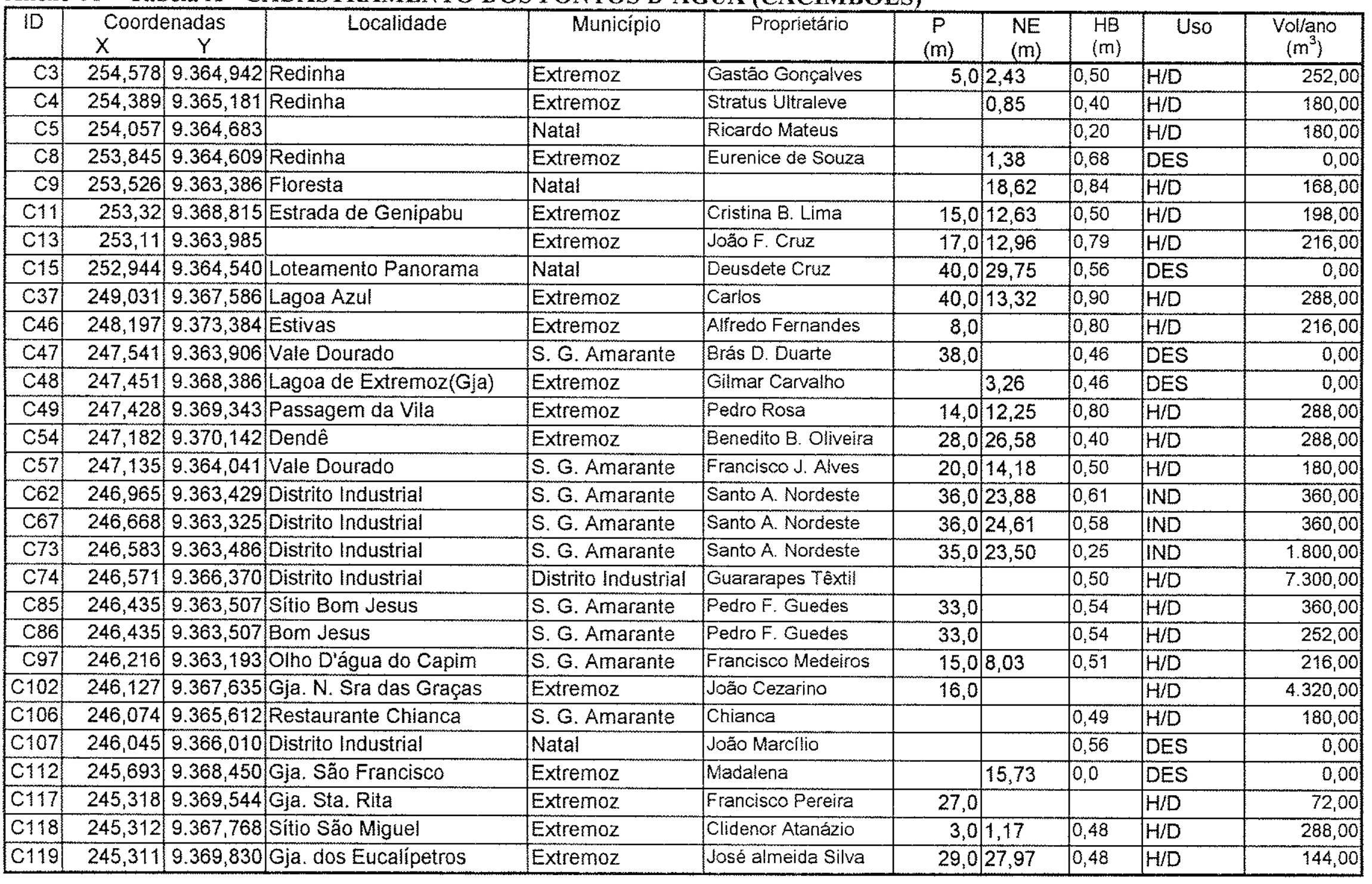


Anexo 01 - Tabela B - CADASTRAMENTO DOS PONTOS D'ÁGUA (CACIMBÕES)

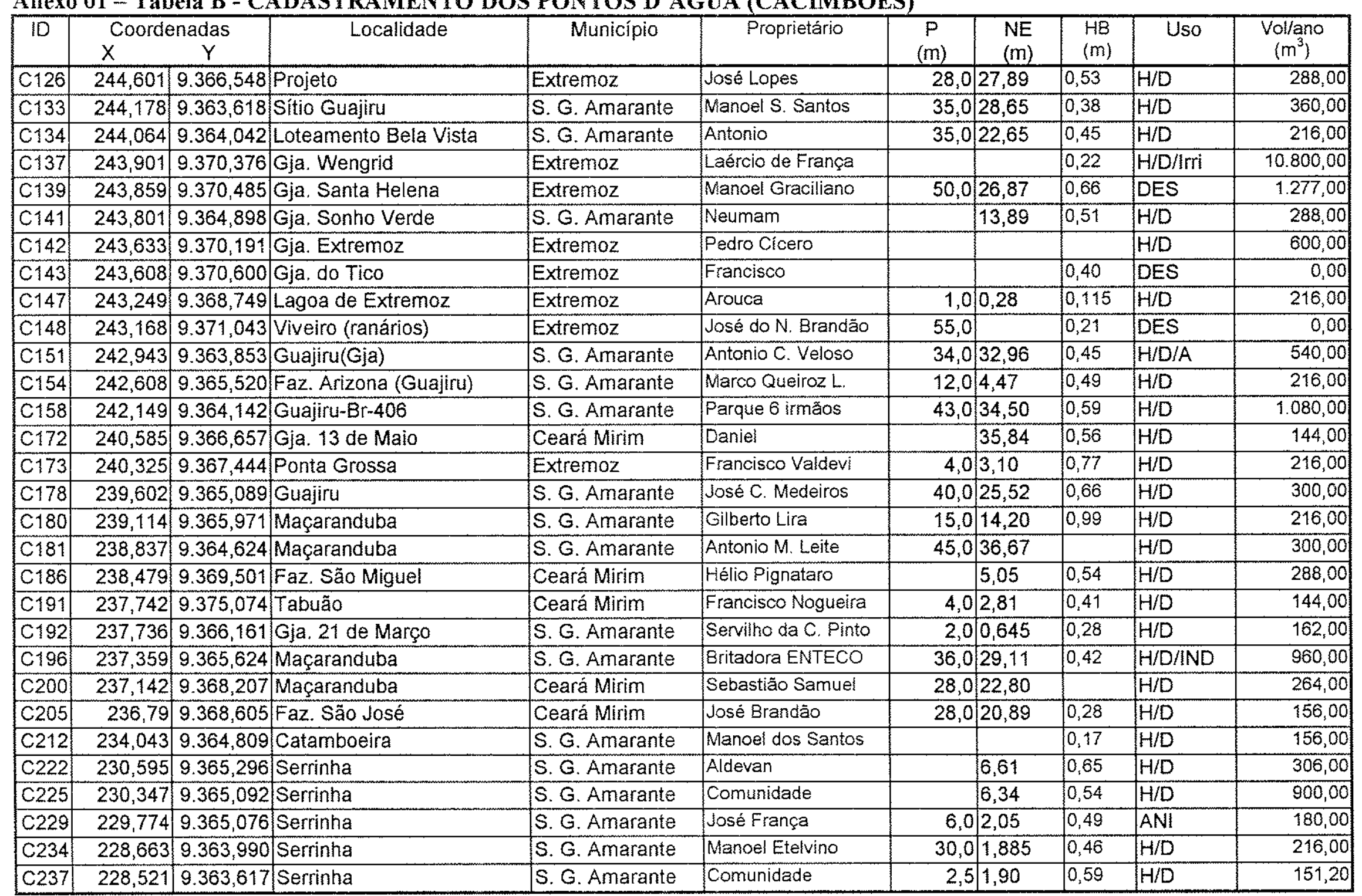


Anexo 01 - Tabela C - CADASTRAMENTO dos PONTOS D'ÁGUA (CACIMBÕ

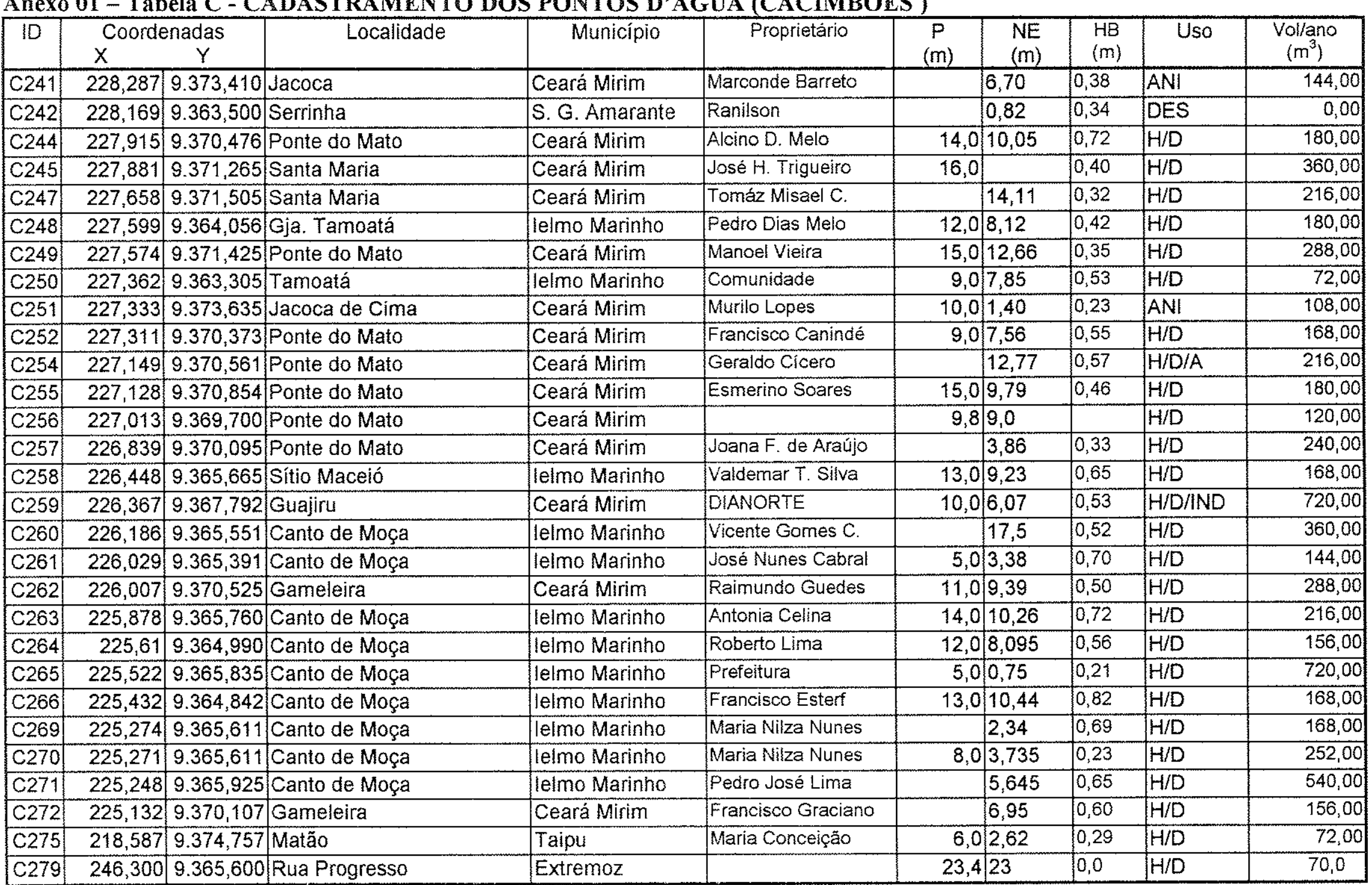


ANEXO 02 - Resultados das Campanhas de Medições Realizadas pela CAERN Período de 1995 a 1996 (Tabelas: $\mathrm{A}-\mathrm{F}$ ) 
Anexo 02 - Tabela A -Resultados das campanhas de medicões realizadas pela CAERN no período de 1995 a 1996

\begin{tabular}{|c|c|c|c|c|c|c|c|c|c|c|c|c|c|}
\hline LOCALIDADE & DATA & COR & TURBIDEZ & ALC. TOTAL & DUREZA TOTAL & $\mathrm{pH}$ & $\mathrm{Cr}$ & $O D$ & $\mathrm{DBO}_{5}$ & DQO & STD & $\mathrm{CT}$ & CF \\
\hline & Coleta & $u^{H}$ & (mg/L $\left.\mathrm{SiO}_{2}\right)$ & $\mathrm{mg} / \mathrm{L} \mathrm{CaCO} 3$ & $(\mathrm{mg} / \mathrm{L} \mathrm{CaCO})$ & & $(\mathrm{mg} / \mathrm{L})$ & $(\mathrm{mg} / \mathrm{L})$ & (mg/L) & (mg/L) & $(\mathrm{mg} / \mathrm{L})$ & (NMP/100ml) & (NMP/100ml) \\
\hline Rio Guajiru - Br-406 & $13 / 03 / 95$ & 35,0 & 7.6 & 69,3 & 108,0 & 6,5 & 115,0 & 4,8 & 1,3 & & 392,0 & $92.000,0$ & $92.000,0$ \\
\hline Rio Guajiru - Br-406 & $1705 / 05$ & 110,0 & 8,7 & 25,3 & 56,0 & 6,6 & 116,0 & 6,3 & 0,7 & 48,0 & 326,0 & $9.200,0$ & \\
\hline Rio Guajiru - Br 406 & $12 / 06 / 95$ & 90,0 & 6,0 & 36,3 & 86,0 & 7,1 & 105,0 & 5,6 & 1,1 & 168,0 & 310,0 & $5.400,0$ & $5.400,0$ \\
\hline Rio Guajiru - Br 406 & 2407105 & 110,0 & 15,0 & 30,8 & 56,0 & 6.6 & 79,0 & 4,2 & 0,3 & 64,0 & 644,0 & $1.700,0$ & - \\
\hline Rio Guajiru - Br-406 & $18 \times 09,95$ & 22,0 & 2,7 & 46,2 & 82,0 & 6,5 & 110,0 & 6,6 & 1,0 & 40,0 & 640,0 & $1.700,0$ & - \\
\hline Rio Guajiru - Br-406 & $16 / 10,95$ & 55,0 & 9,0 & 54,6 & 94,0 & 6,9 & 117,0 & 5,1 & 1,0 & 64,0 & 330,0 & $16.000,0$ & - \\
\hline Rio Guajiru - Br-406 & $20 / 1195$ & 35,0 & 2,8 & 57,0 & 84,0 & 6,9 & 124,0 & 5,4 & 1,0 & 80,0 & 398,0 & 800,0 & - \\
\hline Rio Guajiru - Br-406 & $08 \% 106$ & 55,0 & 2,5 & 68,2 & 97,5 & 6,6 & 112,0 & 6,1 & 2,0 & 80,0 & 321,0 & $3.300,0$ & - \\
\hline Rio Guajiru - Br-406 & 2201190 & 55,0 & 6,5 & 66,1 & 101,0 & 6,9 & 128,0 & 4,2 & 0,7 & 96,0 & 342,0 & $22.000,0$ & $11.000,0$ \\
\hline Rio Cuairru - Br-406 & $26 / 02190$ & 110,0 & 36,0 & 79,8 & 111,0 & 7,1 & 130,0 & 3,3 & 1,9 & 48,0 & 376,0 & - & - \\
\hline Rio Guajiru - Br-406 & $21 / 03 / 96$ & 55,0 & 7,2 & 74,5 & 156,0 & 7,5 & 178,0 & 3,5 & 0,4 & 184,0 & 46,0 & $5.000,0$ & - \\
\hline Rio Guajiru - Br-406 & $17 / 06 / 96$ & 45,0 & 11,0 & 131,0 & 267,0 & 7,2 & 322,0 & 4.9 & 0,6 & 28,0 & 962,0 & $2.200,0$ & - \\
\hline Rio Guajiru - Br-406 & 2220706 & 25,0 & 2,7 & 50,4 & 66,0 & 7,0 & 128,0 & 5,2 & 0,4 & 27,4 & 376,0 & $5.000,0$ & - \\
\hline Rio Guajiru - Br-406 & $1208 / 96$ & 25,0 & 4,0 & 48,3 & 70,4 & 7,3 & 129,00 & 5,30 & & 0,80 & 292,00 & $5.000,00$ & $=$ \\
\hline Valor máximo & & 110,0 & 36,0 & 131,0 & 267,0 & 7,5 & 322,0 & 6,6 & 2,0 & 184,0 & 962,0 & $92.000,0$ & $92.000,0$ \\
\hline Valor médio & & 59,1 & 8,7 & 59,8 & 102,5 & 6,9 & 135,2 & 5,0 & 1,0 & 71,4 & 414,6 & $12.092,9$ & $8.338,5$ \\
\hline Vator minimo & & 22,0 & 2,5 & 25,3 & 56,0 & 6,5 & 79,0 & 3,3 & 0,3 & 0,8 & 46,0 & - & - \\
\hline
\end{tabular}


Anexo 02 - Tabela B -Resultados das campanhas de medicões realizadas pela CAERN no período de 1995 a 1996

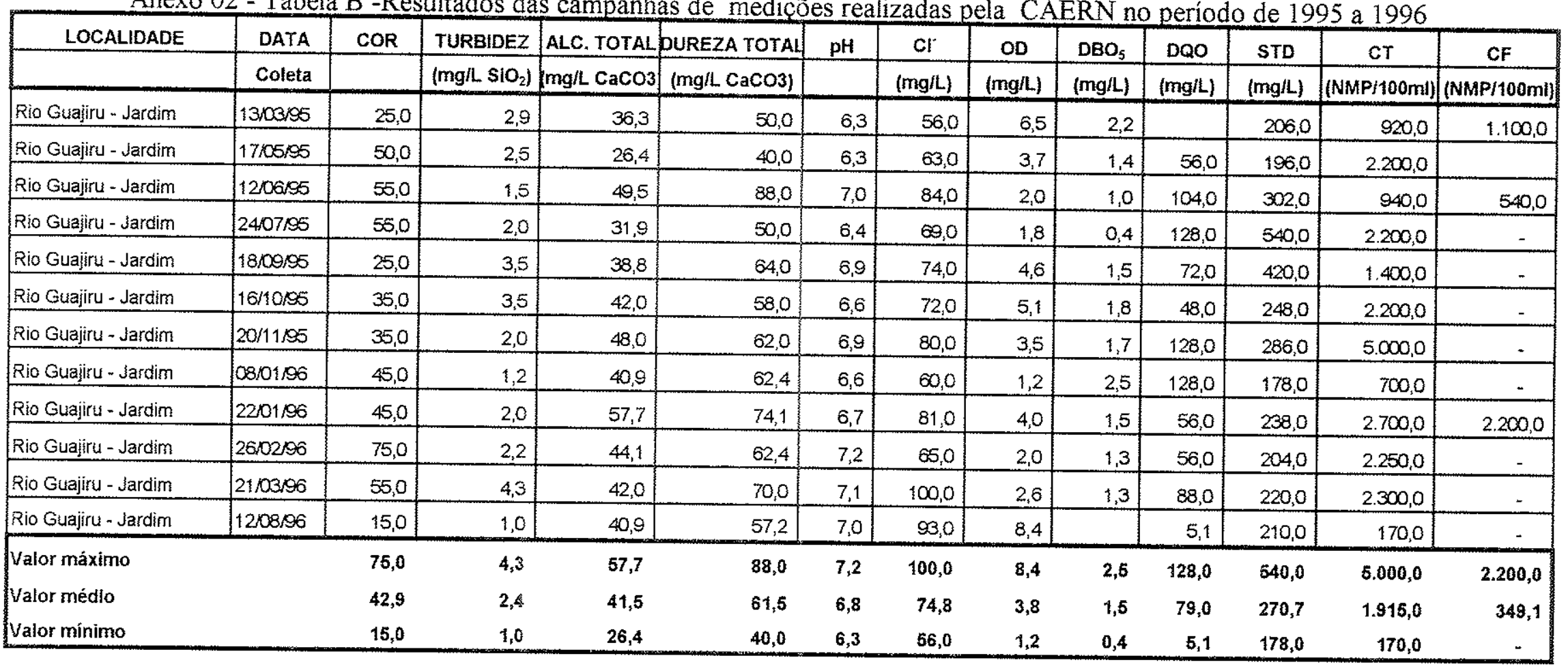


Anexo 02 - Tabela C -Resultados das campanhas de mediçoes realizadas pela CAERN no período de 1995 a 1996

\begin{tabular}{|c|c|c|c|c|c|c|c|c|c|c|c|c|c|}
\hline LOCALIDADE & DATA & COR & TURBIDEZ & ALC. TOTAL & DUREZA TOTAS & $\mathrm{pH}$ & $\mathrm{Cr}$ & $O D$ & $\mathrm{DBO}_{5}$ & DQO & STD & $\mathrm{cT}$ & CF \\
\hline & Coleta & & $\left(\mathrm{mg} / \mathrm{L} \mathrm{S}^{\prime} \mathrm{O}_{2}\right)$ & $\mathrm{mg} / \mathrm{L} \mathrm{CaCO}_{3}$ & (mg/L CaCO3) & & $(\mathrm{mg} / \mathrm{L})$ & (mg/L) & (mg/L) & (mg/L) & (mg/L) & (NMP/100m) & (NMP/100m \\
\hline Rio do Mudo - $\mathrm{Br}-406$ & $13,03,95$ & 25,0 & 12,0 & 158,4 & 216,0 & 6,5 & 138,0 & 7,0 & 1,5 & & 572,0 & $22.000,0$ & \\
\hline Rio do Mudo - 8 r 406 & $1206 / 96$ & 75,0 & 4,2 & 86,9 & 236,0 & 7,0 & 408,0 & 4,6 & 0,6 & 152,0 & $1.248,0$ & $1,400,0$ & \\
\hline Rio do Mudo - Br-406 & 1800,95 & 15,0 & 9,5 & 140,7 & 232,0 & 7,2 & 186,0 & 7,0 & 1,5 & 56,0 & - & $1.700,0$ & \\
\hline Rio do Mudo - Br-406 & $16 / 10 / 95$ & 25,0 & 4,5 & 136,0 & 212,0 & 7,5 & 140,0 & 5,0 & 2,1 & 24,0 & 382,0 & $3.000,0$ & \\
\hline Rio do Mudo - Br-406 & $20 / 11 / 95$ & 35,0 & 3,5 & 141,0 & 201,0 & 7,3 & 148,0 & 4,9 & 1,4 & 168,0 & 562,0 & $3.000,0$ & \\
\hline Rio do Mudo - Br-406 & $08,01,96$ & 45,0 & 2,8 & 136,0 & 199,0 & 3.2 & 135,0 & 5,5 & 3,2 & 56,0 & 446,0 & $1.100,0$ & \\
\hline Rio do Mudo - Br-406 & 2201196 & 25,0 & 3,0 & 140,0 & 200,0 & 7,1 & 138,0 & 3,8 & 1,0 & 64,0 & 446,0 & $8.000,0$ & \\
\hline Rio do Mudo - Br-406 & 26102196 & 55,0 & 5,1 & 140,0 & 265,0 & 7,2 & 270,0 & 4,0 & 1,9 & 48,0 & 786,0 & . & \\
\hline Rio do Mudo - Br- 406 & $21,03,96$ & 45,0 & 5,3 & 111,0 & 303,0 & 7.1 & 416,0 & 4,0 & 0,5 & 72,0 & 1123,0 & $1.300,0$ & \\
\hline Rio do Mudo - Br-406 & $20,05,96$ & 35,0 & 11,0 & 137,0 & 200,0 & 7,4 & 240,0 & 5,6 & 0,5 & 44,6 & $\$ 82,0$ & $5.400,0$ & \\
\hline Rio do Mudo - Br-406 & $17 / 06 / 96$ & 55,0 & 7.5 & 38,8 & $\$ 5,0$ & 7,0 & 120,0 & 5,8 & 1,1 & 18,6 & 286,0 & $1.600,0$ & \\
\hline Rio do Mudo - $8 r-406$ & 2207906 & 35,0 & 5,1 & 130,0 & 191,0 & 7,2 & 181,0 & 5,8 & 1,6 & 91,3 & 006,0 & $1.000,0$ & \\
\hline Rio do Mudo - 8 r.406 & 120890 & 7,0 & 5,6 & 144,0 & 220,0 & 7,5 & 152,0 & 3,9 & & 1,7 & 528,0 & 200,0 & \\
\hline Valor máximo & & 75,0 & 12,0 & 158,4 & 363,0 & 7,5 & 416,0 & 7,0 & 3,2 & 168,0 & $1.248,0$ & $22.000,0$ & \\
\hline Valor médio & & 36,7 & 6,1 & 126,1 & 216,1 & 7,2 & 205,6 & 5,1 & 1,4 & 66,4 & 589,8 & $3.869,2$ & \\
\hline Valor minimo & & 7,0 & 2,6 & 38,8 & 65,0 & 6,5 & 120,0 & 3,8 & 0,5 & 1,7 & . & . & \\
\hline
\end{tabular}


Anexo 02 - Tabela D-Resultados das campanhas de medições realizadas pela CAERN no período de 1995 a 1996

\begin{tabular}{|c|c|c|c|c|c|c|c|c|c|c|c|c|c|}
\hline LOCALIDADE & DATA & COR & TURBIDEZ & ALC. TOTALP & DUREZA TOTAL & $\mathrm{pH}$ & $\mathrm{Cr}$ & $O D$ & $\mathrm{DBO}_{5}$ & DQO & STD & $\mathrm{CT}$ & $\mathrm{CF}$ \\
\hline & Coleta & & $\left(\mathrm{mg}^{\prime} \mathrm{SiO}_{2}\right)$ & mgil CaCO3 & (mg/L CaCO3) & & (mg/L) & (mg/L) & (mgil) & (mg/L) & (mgh) & (NMP/100m) & (NMP/100m \\
\hline Rio do Mudo - S. Miguel & $13,03,95$ & 25,0 & 5,0 & 78,1 & 134,0 & 6,6 & 148,0 & 4,9 & 1,5 & & 486,0 & $11.000,0$ & $11.000,0$ \\
\hline Rio do Mudo - S. Miguel & 070405 & 75,0 & 9,5 & 58,3 & 138,0 & 6,9 & 176,0 & 2,6 & 1,3 & 53,2 & 514,0 & $1.700,0$ & 340,0 \\
\hline Rio do Mudo - S. Miguel & 120690 & 90,0 & 6,8 & 81,4 & 182.0 & 7,0 & 226,0 & 3,4 & 0,6 & 136,0 & 660,0 & $3.500,0$ & $3.500,0$ \\
\hline Rio do Mudo - S. Miguel & 240795 & 75,0 & 2,5 & 55,0 & 140,0 & 6,7 & 254,0 & 2,5 & 1,0 & 112,0 & $1.462,0$ & $11.000,0$ & - \\
\hline Rio do Mudo - S. Miguel & 180905 & 12,0 & 2,5 & 77,7 & 134,0 & 7,0 & 138,0 & 5,2 & 0,7 & 48,0 & 550,0 & $3.000,0$ & - \\
\hline Rio do Mudo - S. Miguel & $16 / 10 / 95$ & 25,0 & 2,0 & 71,4 & 126,0 & 6,9 & 134,0 & 5,0 & 1,8 & 48,0 & 438,0 & $14,000,0$ & $=$ \\
\hline Rio do Mudo - S. Miguel & $20 / 1105$ & 25,0 & 2,5 & 84,0 & 116,0 & 7,1 & 146,0 & 4,3 & 0,6 & 96,0 & 482,0 & $2.800,0$ & - \\
\hline Rio do Mudo - S. Migue! & $0801 / 96$ & 25,0 & 1,1 & 73,5 & 129,0 & 6,8 & 126,0 & 4,7 & 1,9 & 72,0 & 378,0 & $3.300,0$ & - \\
\hline Rio do Mudo - S. Miguel & 220196 & 25,0 & 2,5 & 73,5 & 115,0 & 6,9 & 134,0 & 3,5 & 0,7 & 80,0 & 362,0 & $50.000,0$ & $9.000,0$ \\
\hline Rio do Mudo - S. Miguel & 26,0296 & 130,0 & 9,0 & 88,2 & 148,0 & 6,8 & 192,0 & 3,0 & 1,6 & 120,0 & 508,0 & 二 & - \\
\hline Rio do Mudo - S. Miguel & $21,03 / 96$ & 45,0 & 4,5 & 90,3 & 164,0 & 7,0 & 198,0 & 3,0 & 0,3 & 40,0 & 460,0 & $2.200,0$ & - \\
\hline Rio do Mudo - S. Miguel & $20 / 05 / 96$ & 35,0 & 9,0 & 79,8 & 137,0 & 6,6 & 165,0 & 3,2 & 0,5 & 26,8 & 446,0 & $1.600,0$ & - \\
\hline Rio do Mudo - S. Miguel & $1706 / 96$ & 55,0 & 4,5 & 78,7 & 150,0 & 7,1 & 188,0 & 4,0 & 0,4 & 9,3 & 516,0 & $5.000,0$ & - \\
\hline Rio do Mudo - S. Miguel & 220796 & 35,0 & 2,6 & 73,5 & 106,0 & 7.0 & 129,0 & 4,9 & 0,9 & 36,5 & 416,0 & $1.700,0$ & - \\
\hline Rio do Mudo - S. Miguel & $1208 / 96$ & 15,0 & 1,8 & 92,4 & 128,0 & 7.4 & 142,0 & 5,5 & & 1,4 & 396,0 & $1.000,0$ & \\
\hline Jalor máximo & & 130,0 & 9,5 & 92,4 & 182,0 & 7,4 & 254,0 & 5,5 & 1,8 & 136,0 & $1.462,0$ & $50.000,0$ & $11.000,0$ \\
\hline Valor médio & & 46,1 & 4,4 & 77,1 & 137,1 & 6,9 & 166,4 & 4,0 & 1,0 & 62,8 & 544,9 & $7.493,3$ & $1.689,3$ \\
\hline Jator minimo & & 12,0 & 1,1 & 55,0 & 106,0 & 6,6 & 126,0 & 2,6 & 0,3 & 1,4 & 362,0 & - & - \\
\hline
\end{tabular}


Anexo 02 - Tabela E -Resultados das campanhas de medições realizadas pela CAERN no período de 1995 a 1996

\begin{tabular}{|c|c|c|c|c|c|c|c|c|c|c|c|c|c|}
\hline LOCALIDADE & DATA & COR & TURBIDEZ & ALC. TOTAL & DUREZA TOTAL & $\mathrm{pH}$ & $\mathrm{Cr}$ & $O D$ & $\mathrm{DBO}_{5}$ & DQO & STD & CT & CF \\
\hline & Coleta & & $\left(\mathrm{mg} / \mathrm{LS} \mathrm{SiO}_{2}\right)$ & mg/L CaCO3 & (mgh $\mathrm{CaCO} 3)$ & & (mgh) & (mg/L) & (mg/L) & (mg/L) & $(\mathrm{mg} / \mathrm{L})$ & (NMP/100ml) & (NMP $/ 100 \mathrm{ml}$ \\
\hline Lagoa de Extremoz & $01,03,95$ & 15,0 & 5,4 & 44,0 & 66,0 & 6,5 & 82,0 & 5,8 & 3,0 & $\wp 0,1$ & 282,0 & 240,0 & 240,0 \\
\hline Lagoa de Extremoz & $0103 / 95$ & 25,0 & 4,5 & 44,0 & 64,0 & 7,5 & 75,0 & 3,4 & 0,1 & 55,0 & 275,2 & $1.600,0$ & \\
\hline Lagoa de Extremoz & $01,04,95$ & 22,0 & 3,0 & 44,0 & 64,0 & 6,8 & 81,0 & 6,4 & 0.9 & $\infty, 8$ & 266,0 & 260,0 & 210,0 \\
\hline Lagoa de Extremoz & $0105 / 90$ & 55,0 & 3,6 & 38,5 & 60,0 & 6,7 & 82,0 & 5,6 & 0,7 & 32,0 & 264,0 & $1.100,0$ & \\
\hline Lagoa de Extremoz & $01 / 0695$ & 55,0 & 1,7 & 36,3 & 72,0 & 7,3 & 94,0 & 5,5 & 0,5 & 56,0 & 286,0 & 240,0 & 79,0 \\
\hline Lagoa de Extremoz & $01 / 07 / 95$ & 35,0 & 2,4 & 38,5 & 74,0 & 6,9 & 115,0 & 6,2 & 0,3 & 64,0 & 810,0 & 110,0 & - \\
\hline Lagoa de Extremoz & 010095 & 15,0 & 8.4 & 40,9 & 78,0 & 7,3 & 127,0 & 7,0 & 1,3 & 8,0 & 645,0 & 80,0 & - \\
\hline Lagoa de Extremoz & $01 / 1095$ & 35,0 & 6,0 & 46,2 & 86.0 & 7,0 & 127,0 & 6,8 & 1,5 & 8,0 & 388,0 & 70,0 & - \\
\hline Lagoa de Extremoz & $01 / 11195$ & 35,0 & 7,5 & 47,0 & 72.0 & 7,3 & 104,0 & 6,8 & 1,7 & 64,0 & 328,0 & 240,0 & - \\
\hline Lagoa de Extremoz & $01 / 01 / 96$ & 25,0 & 1,0 & 49,3 & 87,7 & 7,0 & 116,0 & 7,1 & 1,6 & 72,0 & 308,0 & 70.0 & - \\
\hline Lagoa de Extremoz & $01 / 1 / 96$ & 25,0 & 6,5 & 55,6 & 89,7 & 7,1 & 105,0 & 7,3 & 0,6 & 48,0 & 298,0 & 130,0 & 27,0 \\
\hline Lagoa de Extremoz & $01 / 0296$ & 35,0 & 22,0 & 57,7 & 89,7 & 7,2 & 101,0 & 7,0 & 4,3 & 88,0 & 306,0 & - & - \\
\hline Lagoa de Extremoz & $01 / 03 / 96$ & 3,0 & 1,5 & 48,3 & 117,0 & 7,3 & 120,0 & 7,1 & 2,5 & 70,0 & 272,0 & $\therefore$ & $\therefore$ \\
\hline Lagoa de Extremoz & $01 / 03,96$ & 15,0 & 2,2 & 51,4 & 97,0 & 7,1 & 116,0 & 6,9 & 0,8 & 24,0 & 270,0 & 230,0 & - \\
\hline Lagoa de Extremoz & $01,05 / 96$ & 15,0 & 3,2 & 43,0 & 77,5 & 0,7 & 90,0 & 6,9 & 1,1 & 8,9 & 240,0 & $13.000,0$ & $=$ \\
\hline Lagoa de Extremoz & $01 / 06 / 96$ & 15,0 & 2,8 & 39,9 & 57,5 & 7,0 & 88,0 & 8,0 & 0,8 & 9,3 & 254,0 & $1.600,0$ & 300,0 \\
\hline Valor máximo & & 56,0 & 22,0 & 57,7 & 117,0 & 7,5 & 127,0 & 8,0 & 4,3 & 88,0 & 810,0 & $13.000,0$ & 300,0 \\
\hline Valor médlo & & 26,6 & 5,1 & 46,3 & 78,9 & 7,0 & 101,4 & 6,5 & 1,4 & 46,5 & 343,3 & $1.185,6$ & 61,1 \\
\hline Valor minimo & & 3,0 & 1,0 & 36,3 & 60,0 & 6,5 & 75,0 & 3,4 & 0,1 & 8,0 & 240,0 & - & - \\
\hline
\end{tabular}


Anexo 02 - Tabela F -Resultados das campanhas de medições realizadas pela CAERN no período de 1995 a 1996

\begin{tabular}{|c|c|c|c|c|c|c|c|c|c|c|c|c|c|}
\hline LOCALIDADE & DATA & $\mathrm{COR}$ & TURBIDEZ & ALC. TOTALS & DUREZA TOTAL & $\mathrm{pH}$ & Cl- & $\mathrm{OD}$ & DBO5 & DQO & STD & CT & CF \\
\hline & Coleta & & $(\mathrm{mg} / \mathrm{L} \mathrm{SlO} 2)$ & mg/L CaCO3 & (mg/L CaCO3) & & (mglL) & (mg/L) & (mg/L) & (mg/L) & (mg/L) & (NMP/100ml) & (NMP/100m) \\
\hline Rio Doce & 070495 & 25,0 & 3,5 & 34,1 & 52,0 & 6,6 & 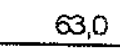 & 3,4 & 0,8 & $\$ 8,4$ & 212,0 & $17.000,0$ & $11.000,0$ \\
\hline Rio Doce & 17005195 & 35,0 & 1.7 & 36,3 & $\infty, 0$ & 6,5 & 72,0 & 5,5 & 0,5 & 40,0 & 216,0 & 920,0 & \\
\hline Rio Doce & 1206,95 & 35,0 & 2,0 & 30,8 & 50,0 & 6,2 & 67,0 & 5,0 & 0,4 & 72,0 & 216,0 & $16.000,0$ & $2.400,0$ \\
\hline Rio Doce & $24,07 / 95$ & 25,0 & 6,4 & 31,9 & 70,0 & 6,5 & 90,0 & 4,3 & 0,5 & 80,0 & $\$ 02,0$ & $7.000,0$ & - \\
\hline Rio Doce & $18 / 09195$ & 12,0 & 2,3 & 25,2 & 50,0 & 6,9 & 66,0 & 5,3 & 0,6 & 24,0 & 540,0 & 900,0 & $=$ \\
\hline Rio Doce & $16 / 1005$ & 15,0 & 1,5 & 26,2 & 44,0 & 6,9 & 53,0 & 6,6 & 1,4 & 24,0 & 178,0 & $17.000,0$ & - \\
\hline Rio Doce & $20 / 11 / 05$ & 25,0 & 2,5 & 44,0 & 53,0 & 7,1 & 58,0 & 6,4 & 2,5 & 48,0 & 220,0 & $90.000,0$ & $=$ \\
\hline Rio Doce & $08101 / 96$ & 25,0 & 2,4 & 26,2 & 48,7 & 6,6 & 46,0 & 6,8 & 1,1 & 40,0 & 126,0 & $5,400,0$ & - \\
\hline Rio Doce & $2201 / 90$ & 15,0 & 2,0 & 29,4 & 52,6 & 0,4 & 46,0 & 7,5 & 2,0 & 64,0 & 120,0 & $9.000,0$ & $9.000,0$ \\
\hline Rio Doce & 26,02196 & 55,0 & 4,3 & 31,5 & 44,8 & 0,7 & 50,0 & 6,2 & 3,5 & 104,0 & 154,0 & - & - \\
\hline Rio Doce & $21 / 03 / 96$ & 15,0 & 4,2 & 37,8 & 51,0 & 7,2 & 80,0 & 6,5 & 3,3 & 40,0 & 182,0 & $17.000,0$ & - \\
\hline Rio Doce & $20,05,96$ & 15,0 & 3,2 & 43,0 & 77,5 & 6,7 & 90,0 & 6,9 & 1,1 & 8,9 & 240,0 & $13,000,0$ & - \\
\hline Rio Doce & $17106 / 96$ & 15,0 & 3,0 & 31,5 & 62,5 & 6,7 & 66,0 & 5,0 & 0,6 & 9,3 & 200,0 & $11.000,0$ & \\
\hline Rio Doce & $2207 / 96$ & 15,0 & 2,5 & 34,5 & 41,8 & 6,4 & 54,0 & 5,1 & 1,1 & 9,1 & 180,0 & 900,0 & - \\
\hline Rio Doce & $1208 / 96$ & 7,0 & 5,6 & 144,0 & 220,0 & 7,5 & 152,0 & 3,9 & & 1,7 & 528,0 & 200,0 & - \\
\hline Valor máximo & & 55,0 & 6,4 & 144,0 & 220,0 & 7,5 & 152,0 & 7,5 & 3,5 & 104,0 & 692,0 & $80.000,0$ & $11.000,0$ \\
\hline Valor médio & & 22,3 & 3,1 & 40,2 & 65,2 & 6,7 & 70,2 & 5,6 & 1,4 & 42,2 & 266,9 & $13.688,0$ & $1.723,1$ \\
\hline Valor minimo & & 7,0 & 1,5 & 25,2 & 41,8 & 6,2 & 46,0 & 3,4 & 0,4 & 1,7 & 120,0 & - & \\
\hline
\end{tabular}


ANEXO 03 - Parâmetros Físicos e Qúmicos das Águas Subterrâneas e Superficiais (Tabelas $\mathrm{A}-\mathrm{E}$ ) 
Anexo 03 - Tabela A-Parâmetros Físicos e Químicos das Águas Subterrâneas e superficiais

\begin{tabular}{|c|c|c|c|c|c|c|}
\hline & No. Pof́o & P-202 & P-136 & P-71 & C-194 & C-260 \\
\hline & Data & $21 / 11 / 97$ & $21 / 1197$ & $21 / 1 / 97$ & $21 / 11 / 97$ & $21 / 11 / 97$ \\
\hline & Municipio & $\mathrm{SG} A \mathrm{Am}$ & Extremoz & Extremoz & C. Mirim & Ielmo.Marinho \\
\hline & Localldade & Macaranduba. & Gja. Wengrid & Laguna lotel & Maçaranduba & Canto de Moca \\
\hline & Profundldade (m) & 100,00 & 30,00 & & 40,0 & 17,50 \\
\hline & Cond. Elétrica $(\mu \mathrm{s} / \mathrm{cm})$ & 672,0 & 74,8 & 213,1 & 119,0 & 307,2 \\
\hline & STD(mg/L) & 487,20 & 81,20 & 200,80 & 102,20 & 246,20 \\
\hline & pII & 7,7 & 4,5 & 7,4 & 6,2 & 7,2 \\
\hline & Dureza(mo/L $\mathrm{CaCO} 3\}$ & 247,34 & 9,75 & 68,25 & 35,41 & 85,18 \\
\hline & $\mathrm{Fe}^{++}(\mathrm{mg} / \mathrm{L})$ & 0,0 & 0,04 & 0,05 & 1,48 & 0,23 \\
\hline \multirow{4}{*}{$\begin{array}{l}\text { Anions } \\
\text { (mg/L) }\end{array}$} & $\mathrm{Cl}^{-}$ & 132,31 & 10,18 & 16,96 & 13,57 & 47,49 \\
\hline & $\mathrm{SO}_{4}^{*}$ & 16,21 & 0,54 & 0,71 & 0,71 & 0,36 \\
\hline & $\mathrm{HCO}_{3}$ & 192,49 & 0,0 & 51,69 & 33,53 & 63,85 \\
\hline & $\mathrm{NO}_{3}$ & 0,0 & 0,0 & 0,0 & 0,0 & 0,0 \\
\hline \multirow{4}{*}{$\begin{array}{l}\text { Cations } \\
\text { (mg/L) }\end{array}$} & $\mathrm{Ca}^{++}$ & 46,43 & 0,82 & 16,96 & 13,57 & 47,49 \\
\hline & $\mathrm{Mg}^{+3}$ & 31,90 & 1,87 & 4,74 & 3,99 & 7,97 \\
\hline & $\mathrm{Na}^{+}$ & 61,82 & 9,62 & 16,54 & 10,77 & 33,75 \\
\hline & $\mathbf{K}^{+}$ & 6,15 & 0,83 & 1,25 & 0,83 & 5,0 \\
\hline \multirow{6}{*}{$\begin{array}{l}\text { Ânions } \\
(\text { meq/L) }\end{array}$} & $\mathrm{rCl}$ & $3,73 ! 1$ & 0,2870 & 0,4782 & 0,3826 & 1,3392 \\
\hline & $\mathrm{rSO}_{4}^{\circ}$ & 0,3374 & 0,0112 & 0,0147 & 0,0147 & 0,074 \\
\hline & $\mathrm{rHCO}_{3}$ & 3,1549 & 0,0 & 0,8471 & 0,5495 & 1,0465 \\
\hline & $\mathrm{rCO}_{3}$ & 0,0 & 0,0 & 0,0 & 0,0 & 0,0 \\
\hline & $\mathrm{rNO}_{3}$ & 0,5242 & 0,3032 & 0,7234 & 0,1909 & 0,8886 \\
\hline & $r \sum a$ & 7,7476 & 0,6014 & 2,063 & 1,1377 & 3,3485 \\
\hline \multirow{5}{*}{$\begin{array}{l}\text { Cátions } \\
(\text { meq/L) }\end{array}$} & $\mathrm{rCa}$ & 2,3168 & 0,0409 & $0,97,40$ & 0,3792 & 1,045 \\
\hline & $\mathrm{rMg}$ & 2,6234 & 0,1537 & 0,3898 & 0,3281 & 0,6554 \\
\hline & $\mathrm{rNa}$ & 2,6891 & 0,4184 & 0,7194 & 0,4684 & 1,4681 \\
\hline & $\mathbf{r K}$ & 0,1572 & 0,022 & 0,0319 & 0,0212 & 0,1279 \\
\hline & $\mathbf{r} \Sigma \mathbf{c}$ & 7,7865 & 0,635 & 2,1151 & 1,1969 & 3,2973 \\
\hline \multirow{7}{*}{$(\%)$} & $\mathrm{rCl}$ & 48,16 & 47,72 & 23,18 & 33,63 & 40,0 \\
\hline & $\mathrm{rSO}_{4}$ & 4,35 & 1,86 & 0,70 & 1,29 & 2,21 \\
\hline & $\mathrm{rHCO}_{3}+\mathrm{rCO}_{3}$ & 40,72 & 0,0 & 40,05 & 48,30 & 31,25 \\
\hline & $\mathrm{rNO}_{3}$ & 6,77 & 50,42 & 35,06 & 16,78 & 26,54 \\
\hline & $\mathrm{rCa}$ & 29,75 & 6,44 & 46,05 & 31,68 & 31,72 \\
\hline & $\mathrm{rMg}$ & 33,69 & 24,20 & 18,43 & 27,41 & 19,88 \\
\hline & $\mathrm{rNa}+\mathrm{K}$ & 36,55 & 69,35 & 35,50 & 40,90 & 48,40 \\
\hline
\end{tabular}


Anexo 03 - Tabela B-Parâmetros Físicos e Químicos das Águas Subterrâneas e Superficiais

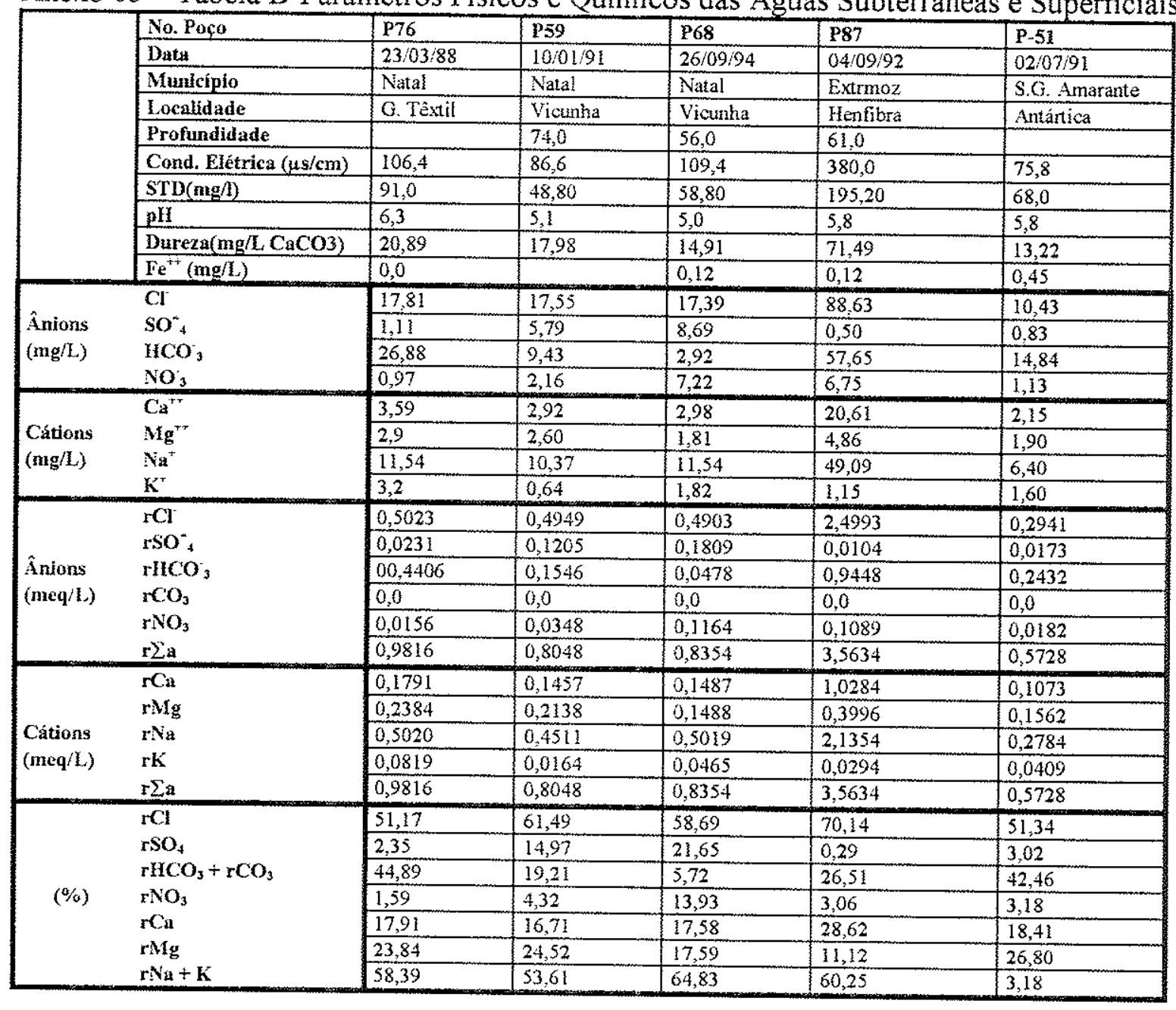




\begin{tabular}{|c|c|c|c|c|c|c|}
\hline & No. Poco & P-202 & $\mathrm{C}-175$ & P-188 & P101 & $C-175$ \\
\hline & Data & $21 / 11 / 97$ & $01 / 04 / 98$ & $01 / 04 / 98$ & $23 / 07 / 97$ & $01 / 04 / 98$ \\
\hline & Municiplo & Extremoz & C. Mirim & S. Gongalo Am & Extremoz & C. Mirim \\
\hline & \begin{tabular}{|l} 
Localidade \\
Profundidade
\end{tabular} & Gja. Santana & Faz Xingu & Casa Caridade & PARMALAT & Faz Xingu \\
\hline & $\begin{array}{l}\text { Profundidade } \\
\text { Cond. Elétrica }(1 \mathrm{~s} / \mathrm{cm})\end{array}$ & & & & & \\
\hline & $\begin{array}{l}\text { Cond. Elétrica }(\mu \mathrm{s} / \mathrm{cm}) \\
\mathrm{STD}(\mathrm{mg} / \mathrm{L})\end{array}$ & 36,0 & 168,4 & 331,1 & 59,0 & 168,4 \\
\hline & $\frac{\operatorname{STD}(m g / L)}{p H}$ & 31,60 & 84,80 & 240,20 & 58,0 & 84,80 \\
\hline & $\frac{\mathrm{pH}}{\text { Dureza(mo/h } \mathrm{CaCO3}}$ & 5,7 & 7,5 & 6,7 & 5,1 & 7,5 \\
\hline & Dureza(mg/L $\mathrm{CaCO} 3)$ & 4,78 & 67,08 & 16,51 & 2,05 & 67,08 \\
\hline & $\mathrm{Fe}^{i t}(\mathrm{mg} / \mathrm{L})$ & 4,84 & 0,07 & 0,01 & 0,13 & 0,07 \\
\hline \multirow{4}{*}{$\begin{array}{l}\text { Anlons } \\
(\mathrm{mg} / \mathrm{L})\end{array}$} & $\mathrm{CI}$ & 10,38 & 27,14 & 23,75 & 11,87 & 27,14 \\
\hline & $\mathrm{SO}_{4}^{-}$ & 1,39 & 0,46 & 23,22 & 0,81 & 0,46 \\
\hline & $\mathrm{HCO}_{3}$ & 3,36 & 68,53 & 94,05 & 7,48 & 68,53 \\
\hline & $\mathrm{NO}_{3}$ & 0,67 & 6,81 & 0,0 & & 6,81 \\
\hline \multirow{4}{*}{$\begin{array}{l}\text { Cátions } \\
\text { (mg/L) }\end{array}$} & $\mathrm{Ca}^{++}$ & 0,85 & 21,90 & 3,51 & 0,41 & 21,90 \\
\hline & $\mathrm{Mg}^{++}$ & 0,64 & 3,01 & 1,88 & 0,25 & 3,01 \\
\hline & $\mathrm{Na}^{\mathrm{T}}$ & 4,80 & 12,80 & 53,33 & 8,08 & 12,80 \\
\hline & $\mathrm{K}^{+2}$ & 0,36 & 1,36 & 4,37 & 3,50 & 1,36 \\
\hline \multirow{6}{*}{$\begin{array}{l}\text { Ânions } \\
\text { (meq/L) }\end{array}$} & $\mathrm{rCl}$ & 0,2927 & 0,7653 & 0,6697 & 0,3347 & 0,7653 \\
\hline & $\mathrm{ESO}_{4}^{-}$ & 0,0289 & 0,0095 & 0,4834 & 0,0168 & 0,0095 \\
\hline & $\mathrm{rHCO}_{3}$ & 0,0550 & 1,1232 & 1,5414 & 0,1225 & 1,1232 \\
\hline & $\mathrm{rCO}_{3}$ & 0,0 & 0,000 & 0,0 & 0,0 & 0,000 \\
\hline & $\mathrm{rNO}_{3}$ & 0,0108 & 0,1098 & 0,0 & & 0,1098 \\
\hline & $r \sum a$ & 0,3874 & 2,0078 & 2,6945 & 0,474 & 2,0078 \\
\hline \multirow{5}{*}{$\begin{array}{l}\text { Cutlons } \\
\text { (meq/L) }\end{array}$} & rCa & 0,0424 & 1,0928 & 0,1751 & 0,0204 & 1,0928 \\
\hline & $\mathrm{rMg}$ & 0,0526 & 0,2475 & 0,1546 & 0,0205 & 0,2475 \\
\hline & $\mathrm{rNa}$ & 0,2088 & 0,5568 & 2,3198 & 0,3514 & 0,5568 \\
\hline & $\mathrm{rK}$ & 0,0092 & 0,0347 & 0,1117 & 0,0895 & 0,0347 \\
\hline & $r \sum a$ & 0,313 & 1,9318 & 2,7612 & 0,4818 & 1,9318 \\
\hline \multirow{7}{*}{$(\%)$} & $\mathrm{rCl}$ & 75,55 & 38,265 & 24,85 & 70,61 & 38,265 \\
\hline & $\mathrm{rSO}_{4}$ & 7,46 & 0,475 & 17,94 & 3,54 & 0,475 \\
\hline & $\mathrm{rffCO}_{3}+\mathrm{rCO}_{3}$ & 14,20 & 56,16 & 57,21 & 25,84 & 56,16 \\
\hline & $\mathrm{FNO}_{3}$ & 13,55 & 5,49 & 0,0 & $\sim$ & 5,49 \\
\hline & $\mathrm{rCa}$ & 16,81 & 56,57 & 6,34 & 4,23 & 56,57 \\
\hline & $\mathrm{rMg}$ & 69,65 & 12,81 & 5,60 & 4,25 & 12,81 \\
\hline & $\mathrm{rNa}+\mathrm{K}$ & 2.78 & 30,62 & 88,04 & 49,34 & 30,62 \\
\hline
\end{tabular}


Anexo 03 - Tabela D-Parâmetros Físicos e Químicos das Águas Subterrâneas e Superficiais

\begin{tabular}{|c|c|c|c|c|c|c|}
\hline & No. Poço & Lagoa & Rio & Rio do Mudo & Lagoa & Lagoa \\
\hline & Data & $27 / 04 / 93$ & $21 / 11 / 97$ & $21 / 1 / 97$ & $01 / 04 / 98$ & $01 / 04 / 98$ \\
\hline & Municíplo & Extremoz & Extremoz & Extremoz & Extremoz & \begin{tabular}{|l} 
Extremoz \\
\end{tabular} \\
\hline & Cond. Elétrica $(\mu \mathrm{s} / \mathrm{cm})$ & 372,4 & 205,4 & 576,0 & 409,6 & 512,1 \\
\hline & $\mathrm{TSD}(\mathrm{mg} / \mathrm{L})$ & 258,0 & 125,6 & 419,0 & 235,20 & 317,60 \\
\hline & pHI & 6,2 & 7,1 & 7,6 & 6,5 & 7,1 \\
\hline & Dureza(mg/L $\mathrm{CaCO})$ & 60,28 & 54,39 & 164,21 & 74,30 & 109,39 \\
\hline & $\mathrm{Fe}^{++}(\mathrm{mg} / \mathrm{L})$ & 0,51 & 0,23 & 0,36 & 0,33 & 0,49 \\
\hline \multirow{4}{*}{$\begin{array}{l}\hat{A} \text { nious } \\
\text { (mg/L) }\end{array}$} & $\mathrm{CI}$ & 81,81 & $42,4 !$ & 144,18 & 81,42 & 101,77 \\
\hline & $\mathrm{SO}_{4}^{-}$ & 3,92 & 4,29 & 8,04 & 2,46 & 2,46 \\
\hline & $\mathrm{HCO}_{3}$ & 59,36 & 52,90 & 125,83 & 53,04 & 84,26 \\
\hline & $\mathrm{NO}_{3}$ & & & 1,73 & 2,30 & 0,31 \\
\hline \multirow{4}{*}{$\begin{array}{l}\text { Cátions } \\
\text { (mg/L) }\end{array}$} & $\mathrm{Ca}^{++}$ & 11,88 & 9,45 & 34,92 & 11,16 & 21,07 \\
\hline & $\mathrm{Mg}^{2+4}$ & 7,44 & 7,48 & 18,69 & 11,28 & 13,79 \\
\hline & $\mathrm{Na}^{+}$ & 43,33 & 21,88 & 74,55 & 38,75 & 47,62 \\
\hline & $\mathrm{K}^{+}$ & 7,22 & 4,17 & 5,00 & 5,77 & 6,54 \\
\hline \multirow{6}{*}{$\begin{array}{l}\text { Anions } \\
\text { (meq/L) }\end{array}$} & $\mathrm{rCl}$ & 2,31 & 1,1959 & 4,0658 & 2,2960 & 2,8699 \\
\hline & $\mathrm{ISO}_{4}^{-}$ & 0,08116 & 0,0893 & 0,1673 & 0,0512 & 0,0512 \\
\hline & $\mathrm{rHCO}_{3}$ & 0,9729 & 0,8670 & 2,0623 & 0,8693 & 1,3810 \\
\hline & $\mathrm{rCO}_{3}$ & 0,0 & 0,0 & 0,0 & 0,0 & 0,0 \\
\hline & $\mathrm{rNO}_{3}$ & 0,0 & 0,0061 & 0,0297 & 0,0370 & 0,0050 \\
\hline & $r \sum a$ & 3,3641 & 2,1522 & 6,2954 & 3,2535 & 4,3071 \\
\hline \multirow{5}{*}{$\begin{array}{l}\text { Cátions } \\
(\mathrm{meq} / \mathrm{L})\end{array}$} & $\mathrm{nCa}$ & 0,5928 & 0,4715 & 1,7425 & 0,5568 & 1,0513 \\
\hline & $\mathrm{rMg}$ & 0,6118 & 0,6151 & 1,5370 & 0,9276 & 1,1340 \\
\hline & $\mathrm{rNa}$ & 1,8848 & 0,9517 & 3,2429 & 1,6856 & 2,0714 \\
\hline & $r K^{\prime \prime}$ & 0,1846 & 0,1066 & 0,1279 & 0,1475 & 0,1672 \\
\hline & $r \sum \mathbf{a}$ & 3,274 & 2,1449 & 6,6503 & 3,3175 & 4,4239 \\
\hline \multirow{7}{*}{$(\%)$} & $\mathrm{FCl}$ & 68,67 & 55,52 & 64,58 & 70,57 & 66,63 \\
\hline & $\mathrm{rSO}_{4}$ & 2,41 & 4,15 & 2,66 & 1,57 & 1,19 \\
\hline & $\mathrm{rHCO}_{3}+\mathrm{rCO}_{3}$ & 23,92 & 40,28 & 32,76 & 26,72 & 32,06 \\
\hline & $\mathrm{rNO}_{3}$ & 0,0 & 0,0 & & 1,14 & 0,12 \\
\hline & $\mathrm{rCa}$ & 18,11 & 21,98 & 26,20 & 16,78 & 23,76 \\
\hline & $\mathrm{rMg}$ & 18,69 & 28,68 & 23,11 & 27,96 & 25,63 \\
\hline & $\mathrm{rNa}+\mathrm{K}$ & 63,06 & 49,34 & 50,68 & 55,26 & 50,78 \\
\hline
\end{tabular}


Anexo 03 - Tabela E-Parâmetros Físicos e Químicos das Aguas Subterrâneas e Superficiais

\begin{tabular}{|c|c|c|c|}
\hline & No. Pago & P-188 & P-213 \\
\hline & Data & $01 / 04 / 98$ & $01 / 04 / 98$ \\
\hline & Municipio & S. G. Amarante & S.G. Amarante \\
\hline & Localidade & Casa Caridade & Gja S.Pedro \\
\hline & Profundidade & & 110,0 \\
\hline & Cond. Elétrica ( $\mu \mathrm{s} / \mathrm{cm})$ & 331,1 & 252,6 \\
\hline & $\mathrm{TSO}(\mathrm{mg} / \mathrm{L})$ & 240,20 & 187,0 \\
\hline & $\mathrm{pll}$ & 6,7 & 6,7 \\
\hline & Dureaa(mg/L CaCO3) & 16,51 & 24,77 \\
\hline & $\mathrm{Fe}^{++}(\mathrm{mg} / \mathrm{L})$ & 0,01 & 0,06 \\
\hline \multirow{4}{*}{$\begin{array}{l}\text { Annions } \\
(\mathbf{m g} / \mathbf{L})\end{array}$} & $\mathrm{Cl}$ & 23,75 & 50,89 \\
\hline & $\mathrm{SO}_{4}^{-}$ & 23,22 & 8,92 \\
\hline & $\mathrm{HCO}_{3}$ & 94,05 & 49,32 \\
\hline & $\mathrm{NO}_{3}$ & 0,0 & 0,45 \\
\hline \multirow{4}{*}{$\begin{array}{l}\text { Cátions } \\
(\mathrm{mg} / \mathrm{L})\end{array}$} & $\mathrm{Ca}^{*+}$ & 3,51 & 3,72 \\
\hline & $\mathrm{Mg}^{++}$ & 1,88 & 3,76 \\
\hline & $\mathrm{Na}^{*}$ & 53,33 & 37,89 \\
\hline & $\mathbf{K}^{+}$ & 4,37 & 4,55 \\
\hline \multirow{6}{*}{$\begin{array}{l}\text { Ânions } \\
(\text { meq/L) }\end{array}$} & $\mathrm{rCl}$ & 0,6697 & 1,4350 \\
\hline & $\mathrm{SSO}_{4}$ & 0,4834 & 0,1857 \\
\hline & $\mathrm{rHCO}_{3}$ & 1,5414 & 0,8083 \\
\hline & $\mathrm{rCO}_{3}$ & 0,0 & 0,0 \\
\hline & $\mathrm{rNO}_{3}$ & 0,0 & 0,0072 \\
\hline & $\mathbf{r} \Sigma \mathbf{a}$ & 2,6945 & 2,4362 \\
\hline \multirow{5}{*}{$\begin{array}{l}\text { Cátions } \\
(\mathrm{meq} / \mathrm{L})\end{array}$} & $\mathrm{raa}$ & 0,1751 & 0,1856 \\
\hline & $\mathrm{rMg}$ & 0,1546 & 0,3092 \\
\hline & $\mathrm{rNa}$ & 2,3198 & 1,6482 \\
\hline & $\mathrm{rk}$ & 0,1117 & 0,1163 \\
\hline & ria & 2,7612 & 2,26 \\
\hline \multirow{7}{*}{$(\%)$} & $\mathrm{rCl}$ & 24,85 & 58,90 \\
\hline & $\mathrm{rSO}_{4}$ & 17,94 & 7,62 \\
\hline & $\mathrm{rHCO}_{3}+\mathrm{rCO}_{3}$ & 57,21 & 33,18 \\
\hline & $\mathrm{FNO}_{3}$ & 0,0 & 0,0029 \\
\hline & $\mathrm{rCa}$ & 6,34 & 8,21 \\
\hline & $\mathrm{rMg}$ & 5,60 & 13,58 \\
\hline & $\mathrm{rNa}+\mathrm{K}$ & 88,04 & 78,15 \\
\hline
\end{tabular}

